UNIVERSIDADE DE SÃO PAULO

FACULDADE DE FILOSOFIA LETRAS E CIÊNCIAS HUMANAS

DEPARTAMENTO DE GEOGRAFIA

PROGRAMA DE PÓS-GRADUAÇÃO EM GEOGRAFIA FÍSICA

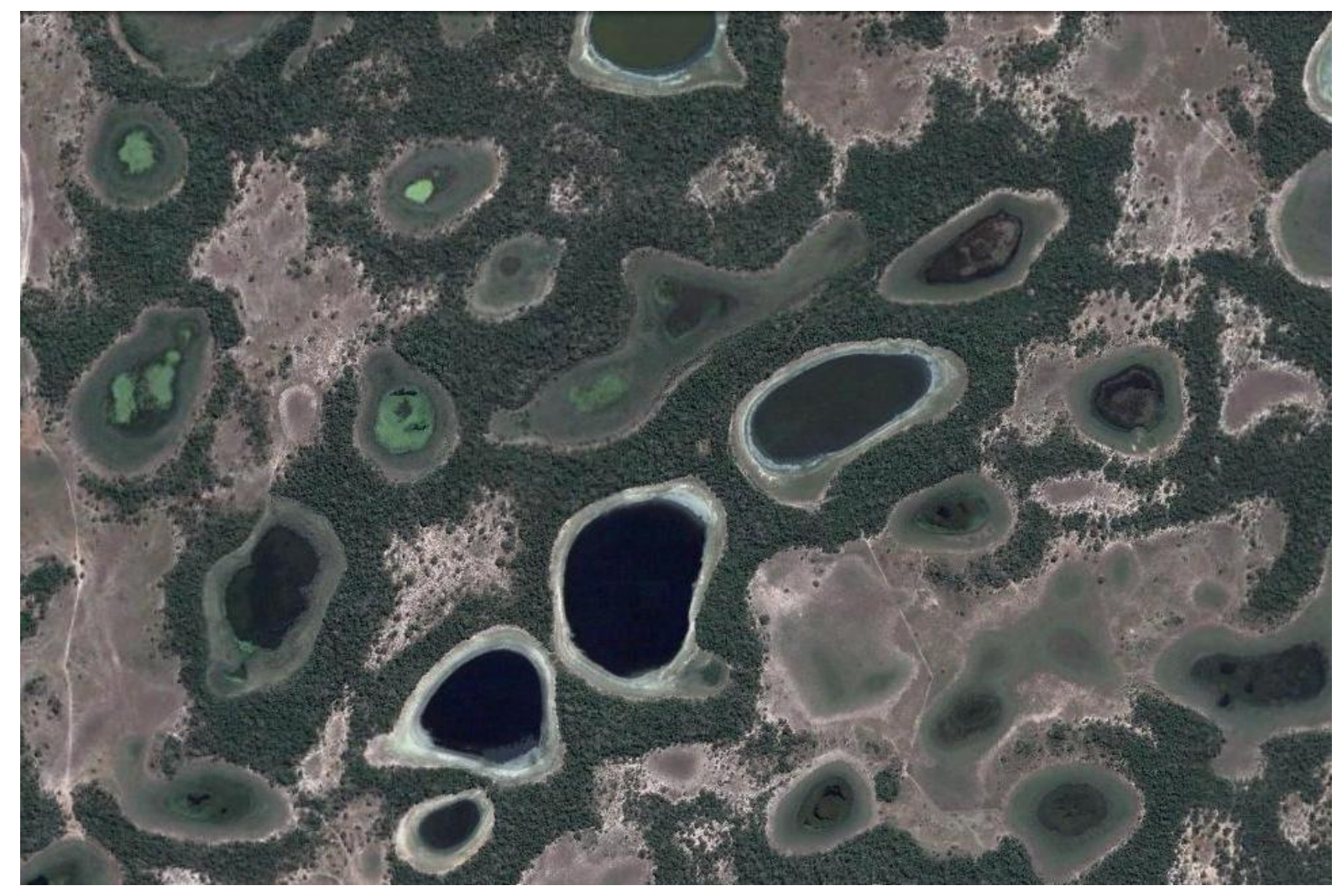

TIPOLOGIA DE LAGOAS SALINAS NO PANTANAL DA NHECOLÂNDIA (MS)

ELISÂNGELA ROSEMERI CURTI MARTINS

São Paulo

2012 
UNIVERSIDADE DE SÃO PAULO

FACULDADE DE FILOSOFIA, LETRAS E CIÊNCIAS HUMANAS DEPARTAMENTO DE GEOGRAFIA

PROGRAMA DE PÓS-GRADUAÇÃO EM GEOGRAFIA FÍSICA

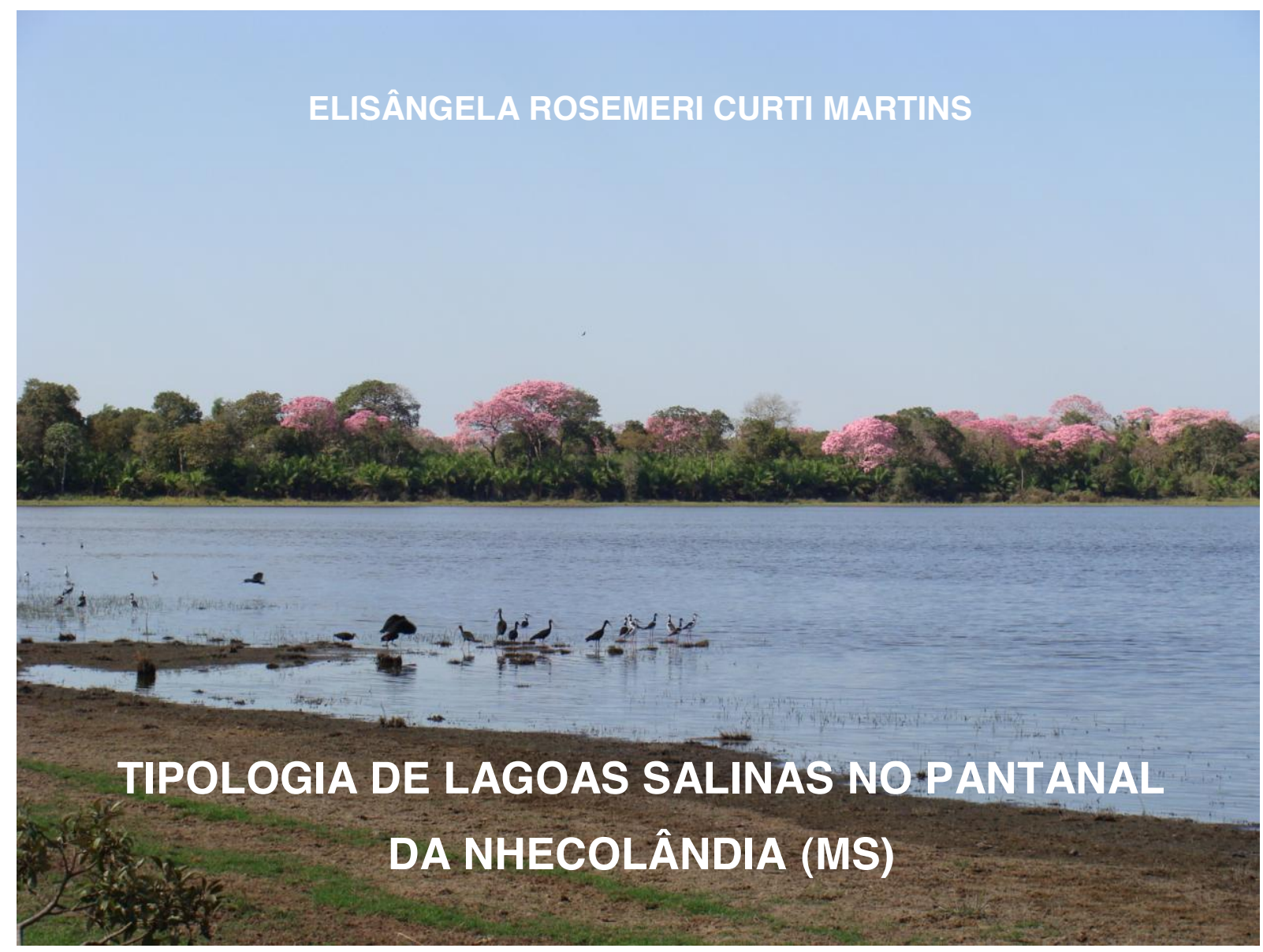

SÃO PAULO

2012 


\author{
UNIVERSIDADE DE SÃO PAULO \\ FACULDADE DE FILOSOFIA, LETRAS E CIÊNCIAS HUMANAS \\ DEPARTAMENTO DE GEOGRAFIA \\ PROGRAMA DE PÓS-GRADUAÇÃO EM GEOGRAFIA FÍSICA
}

\title{
TIPOLOGIA DE LAGOAS SALINAS NO PANTANAL DA NHECOLÂNDIA (MS)
}

\section{Elisângela Rosemeri Curti Martins}

Tese apresentada ao Programa de Pós-Graduação em Geografia Física da Faculdade de Filosofia, Letras e Ciências Humanas da Universidade de São Paulo, para a obtenção do título de Doutor em Ciências.

Orientador: Prof ${ }^{a}$. Dra ${ }^{a}$ Sônia Maria Furian 
Dedico este trabalho aos meus amados pais Ivo e Amabile. Meu reconhecimento e gratidão por todos os ensinamentos recebidos, apoio e incentivo ao longo da minha vida. 


\section{AGRADECIMENTOS}

A conclusão desta Tese contou com a ajuda, colaboração e compreensão de uma grande equipe formada por orientadores, professores, colegas, amigos, familiares e instituições. A todos o meu muito OBRIGADO e minha profunda GRATIDÃO.

\section{Aos professores:}

A Prof ${ }^{a}$ Dra $^{a}$ Sônia Maria Furian por orientar este trabalho, com grande dedicação e sabedoria e, por dar-me oportunidade de participar de um grupo de pesquisa que muito contribuiu para meu crescimento acadêmico.

Ao Prof Dr. Laurent Barbiéro, IRD; LMTG, Université de Toulouse, France; CENA/USP - Piracicaba, pela co-orientação, dedicação nas missões de campo e apoio material.

A banca de qualificação: Prof ${ }^{a} r^{a}$ Nádia Regina do Nascimento e o Prof. Dr. Adilson Avansi de Abreu pelas sugestões que vieram enriquecer este trabalho.

Ao Prof Dr. Mário De Biasi pelo incentivo a buscar novos conhecimentos para minha formação, e me aceitar como orientanda na seleção para Doutorado no Departamento de Geografia da USP.

Ao Prof. Dr. Reynaldo Luis Victoria pela acolhida no CENA e pelo apoio dado aos projetos de pesquisas do grupo no qual me inseri, principalmente o Projeto FAPESP $\mathrm{N}^{\circ}$ 2008/09086-7 e 2011/12770-0, quadro no qual realizei este trabalho de doutorado, e por todo apoio logístico de laboratório e campo.

À Prof ${ }^{a}$ Dra $^{\mathrm{a}}$. Rosely Pacheco Dias Ferreira pelo carinho e pela inspiração dada na confecção da tabela 13 desta tese, e a $\operatorname{Prof}^{a} \mathrm{Dr}^{\mathrm{a}}$. Sidneidi Manfredini pelo carinho, apoio e incentivo à pesquisa.

\section{Às Instituições e aos Laboratórios:}

À USP, pela oportunidade de acesso a novos conhecimentos no Curso de Doutorado em Geografia Física. 
Às Secretárias de Pós-graduação Rosângela, Cida, Jurema e em especial, nossa queridíssima Ana, hoje aposentada, pelo profissionalismo e presteza no dia a dia.

Aos funcionários da Secretaria de Graduação de Geografia/USP pelo auxílio em questões administrativas e de material, durante o desenvolvimento desta pesquisa.

À UFMS por conceder um carro $4 \mathrm{X} 4$ de apoio para realização dos trabalhos de campo e ao Prof. Dr. Ary Tavares Rezende Filho, pelo apoio na coleta de dados no campo, elaboração de mapas e empréstimo de material.

Ao Laboratório de Pedologia pelo empréstimo de material, equipamentos e pela agradável convivência entre colegas e professores.

Ao Prof. Dr. Paulo César Fonseca Giannini responsável pelo Laboratório de Sedimentologia (Instituto de Geociências/USP), e à Elaine Aparecida da Silva Sinfrônio, pela disposição em auxiliar nos procedimentos analíticos, e pela amizade.

Ao Prof. Dr. Daniel Atêncio responsável pelo Laboratório de Difração de Raios X do Instituto de Geociências/USP, e ao técnico Dr. Flávio Machado de Souza Carvalho.

Ao Laboratório de Ecologia Ambiental e Geoprocessamento (NUPEGEL/ CENA/ESALQ/USP) pelas análises químicas das águas.

Ao CNPq, pela bolsa concedida, essencial para minha permanência em São Paulo e dedicação à pesquisa.

A COSEAS pela moradia no Conjunto Residencial da USP.

\section{Aos amigos e familiares:}

À Tatiana Mascari Parizotto e Marcos Roberto Pinheiro pela amizade e auxílio nos trabalhos em laboratório.

À amiga Ana Cristina Machado Rodriguez, pela amizade, incentivo e por estar sempre por perto nos momentos mais importantes da minha vida.

Ao amigo Nelson Caetano pela amizade incondicional e apoio na diagramação desta Tese. 
Às amigas Grismar de Souza e Marisa Briones Velasco pela amizade e carinho ao longo desses anos de convivência.

Às amigas Cristiane Regina Michelon, Liane Welter, Michella Di Candia e Cristina Camolez e ao amigo Marciel Lohmann, que apesar da distância sempre acompanharam minhas dificuldades e realizações pessoais e acadêmicas.

Aos amigos Paula e Fernando Manfio pelo carinho, amizade e incentivo.

Aos meus amados pais Ivo Vaz Martins e Amabile Maria Curti, pelo incentivo e compreensão pelas inúmeras vezes que me fiz ausente em momentos especiais da nossa família.

Aos meus irmãos Cezar Odacir Curti Martins e família, Rogério e Regina Veeck.

Ao meu marido Weslem Liberato Silva, pelo amor, carinho, compreensão e apoio incondicional para meu crescimento profissional e realização deste trabalho.

\section{E em especial,}

A Moreli Teixeira Arantes, proprietária da Fazenda Centenário (Aquidauana/MS), pelo apoio à nossa pesquisa, especialmente por autorizar nosso trabalho que se desenvolveu em quatro salinas localizadas em sua propriedade. Sem este apoio não seria possível a realização desta tese.

Ao Paul Michael Grol por disponibilizar um alojamento na Fazenda Embiaria sem o qual não seria possível realizar esta pesquisa nessa área.

E também da Fazenda São João a dona Antonia Ayala Matos e Ramona Alice Gonçalves pela acolhida calorosa sem a qual em muitos momentos teria sido difícil nossa estadia no campo.

Em especial, ao Joelson J. Gonçalves Teodoreto por todo apoio logístico e pelos conhecimentos do Pantanal, valiosos, sobretudo na estação úmida, para nossos deslocamentos pela Baixa Nhecolândia.

A todos aqueles que de alguma forma contribuíram na realização desta pesquisa. 


\section{RESUMO}

A Nhecolândia é uma sub-região do Pantanal Mato-Grossense, que se caracteriza pela presença de um amplo sistema lacustre formado por milhares de lagoas com contornos arredondados. Pesquisas anteriores mostram uma grande variabilidade entre as lagoas, que são mais ou menos salinas, mas que coexistem na paisagem a algumas dezenas, ou centenas, de metros de distância umas das outras. O objetivo geral deste trabalho foi compreender essa variabilidade no espaço e no tempo, e identificar os processos responsáveis por essa variabilidade, a fim de elaborar uma tipologia de lagoas aplicável a essa região. $\mathrm{Na}$ escala regional, a carga total em elementos químicos é a principal fonte de variabilidade das águas de superfície. A distribuição da variável "condutividade elétrica" (CE) não apresenta um padrão de organização espacial, ao menos na escala da amostragem feita neste trabalho, e as análises geoestatísticas indicam uma ação local, na proximidade das salinas, dos processos que controlam a CE das águas. O estudo local, realizado ao redor de quatro salinas, vem corroborar o funcionamento hidrológico de "estruturas em patamares" das salinas descrito na literatura. O presente trabalho reforça a abrangência regional desse funcionamento, que é coerente com a distribuição estatística regional da $\mathrm{CE}$, de caráter bimodal, e com a ação local dos processos ressaltada pelo estudo geoestatístico. Contudo, tal funcionamento hidrológico não pode explicar as variações sazonais da salinidade. Para isto, faz-se intervir uma remobilização, pelas chuvas, de reservatórios de águas hipersalinas armazenadas nas praias, evidenciados pelo mapeamento de CEa por indução eletromagnética. No quadro desta pesquisa, os conhecimentos adquiridos sobre as águas das lagoas, e de seus entornos imediatos, permitem propor um esboço de tipologia de salinas, baseado nos principais eixos de variabilidade que elas apresentam, isto é, Tipo 1 Salina Preta e Tipo 2 Salina Verde. Este estudo coloca em evidência a necessidade de trabalhos interdisciplinares, com técnicas de hidrologia, pedologia, geofísica, geoquímica, limnologia, dentre outras, para abordar geograficamente essa região de lagoas, única no mundo.

Palavras chaves: Lagoas Salinas Alcalinas; Análises Multivariadas; Espacialização; Morfologia dos Solos; Tipologia; Nhecolândia; Pantanal. 


\begin{abstract}
The Nhecolândia is a sub-region of the huge Pantanal of Mato Grosso, characterized by the presence of thousands of round shaped lakes. Previous work pointed out the large variability that exists between these saline or freshwater lakes, although they coexist in close proximity. The main objective of this study was to understand this variability in time and space, and to identify the processes responsible for this variability in order to develop a typology of lakes suitable for the region. At the regional scale, the total chemical charge was the main variability of surface waters. The distribution of the variable "Electrical Conductivity" (EC) did not reveal any type of distribution, at least across our sampling. The geostatistical study indicated that the process that controls the water acts locally, in the immediate vicinity of the Lakes. A local study carried out around a few lakes allowed identifying a threshold-based hydrological functioning, which had already been described in the literature. Our study allowed generalizing this functioning. It is in agreement with the bimodal statistical distribution of EC at the regional scale, and with the results of the geostatistical treatment that revealed a local process. However, such hydrological functioning cannot explain the seasonal changes in salinity. It must involve the remobilization, by the rains, of hyper-salines water stored around the lakes, and which have been surveyed by sub-surface electromagnetic induction. From the results of this work, both on lakes and on their immediate environment, we proposed a draft of lake typology based on the main axis of variability, that is Type 1 Preta Saline Lake and Type 2 Verde Saline Lake. The study highlighted the benefits of crossing several disciplines and technics (hydrological, pedological, geophysical, geochemical, limnological, among other) in a geographical approach of this singular region.
\end{abstract}

Keywords: Saline alkaline lakes; Multivariate Analysis; Spatialization; Morphology of the Soil; Typology; Nhecolândia; Pantanal. 


\section{RÉSUMÉ}

La Nhecolândia est une sous-région du vaste Pantanal Mato-Grossense qui se caractérise par la présence de milliers de lacs aux contours arrondis. Les travaux antérieurs ont souligné la grande variabilité qui existe entre ces lacs plus ou moins salés, mais qui se côtoient dans le paysage à quelques dizaines ou quelques centaines de mètres de distance. L'objectif général de ce travail était de comprendre cette variabilité, dans l'espace et dans le temps, et d'identifier les processus responsables afin d'élaborer une typologie de lacs applicable à cette région. A l'échelle régionale, la charge totale des eaux en éléments chimiques est la principale variabilité des eaux de surface. La répartition de la variable «conductivité électrique » (CE) ne présente pas d'organisation type, du moins à l'échelle de notre échantillonnage. En revanche, l'étude géostatistique indique que le processus qui contrôle la CE des eaux agit localement, à proximité immédiate des lacs. L'étude locale réalisée sur le pourtour de quelques lacs permet d'identifier un fonctionnement hydrologique à seuil, qui avait déjà été décrit dans la littérature. Notre étude permet de généraliser ce fonctionnement. II est en accord avec la distribution statistique régionale de la $\mathrm{CE}$ (distribution bimodale) et avec l'étude géostatistique (processus local). Cependant, un tel fonctionnement hydrologique ne peut pas expliquer les variations saisonnières de la salinité. II faut faire intervenir la remobilisation par les pluies de réservoirs d'eau hyper-salines stockées dans les plages, et qui ont été mis en évidence par induction électromagnétique de sub-surface. Les connaissances acquises dans le cadre de ce travail, tant sur les eaux des lacs que sur leur environnement immédiat, permettent de proposer une ébauche de typologie fondée sur les principaux axes de variabilités, à savoir Type 1 Lac Salin Preta et Type 2 Lac Salin Verde. L'étude mets en évidence la nécessité de l'application de plusieurs disciplines (hydrologique, pédologique, géophysique, géochimique, Limnologique, entre autres) dans un abordage géographique de cette région unique au monde.

Mots clés: Lacs salins-alcalins; Analyse Multivariée; Spatialisation; Morphologie du Sol; Limnologique; Typologie; Nhecolândia; Pantanal. 


\section{LISTA DE FIGURAS}

Figura 1. Localização do Pantanal Mato-grossense na Bacia do Alto Paraguai.

Figura 2. Regiões Fisiográficas da Bacia do Alto Paraguai (Fonte: Rezende Filho, 2011).

Figura 3 Sub-regiões do Pantanal Mato-grossense de Silva e Abdon (1998), (Fonte: Rezende Filho, 2011).

Figura 4. Principais feições da paisagem da Nhecolândia (Fonte: Barbiéro et al., 2002).

Figura 5. Deserto Badain Jaran (China): afloramento do lençol freático em superfície e aparecimento de lagoas nas depressões interdunas (Gates et al., 2008).

Figura 6. Visão oblíqua do complexo de lagoas no Sudoeste da Austrália. Nota-se a forte salinidade que se cristaliza em eflorescências brancas durante a estação seca (Imagem Google Earth, 2011).

Figura 7. Terraço do Vale Zambeze (Zâmbia) com lagoas em forma de "lunettes" (Imagem Google Earth, 2011)

Figura 8. Lagos cársticos na Central da Flórida (Imagem Google Earth, 2011)

Figura 9. Lagoas no Pantanal da Nhecolândia (MS), Fonte: Imagem Google Earth/2010.

Figura 10. Subdivisão morfológica do Leque do Taquari em 7 lobos baseado nas características geométricas dos paleocanais (Assine, 2003).

Figura 11. Leque do rio Kosi, Índia. (Fonte: Imagem Landstat, fevereiro de 1977, NASA, Assine, 2004)

Figura 12. Lagos no leque do Kosi: (a) de meandros abandonados, e (b) na parte inferior da imagem lagos rasos, e na superior, lagos retangulares de origem antrópica, Índia (Imagens Google 
Earth, 2011)

Figura 13. Leque aluvial do Rio Okavango - Botsuana (Imagem Google Earth, 2011).

Figura 14. Localização das amostragens I, II e III no Pantanal da Nhecolândia

Figura 15. Características do semivariograma

Figura 16. Distribuição das variáveis no primeiro plano fatorial da ACP.....

Figura 17. Distribuição das amostras e das variáveis no primeiro plano fatorial da ACP.

Figura 18. Diagrama de concentração: (a) cátions e (b) ânions

Figura 19. Histogramas: (a) da variável CE e (b) de $\log _{10}(C E)$

Figura 20. Correlação entre $\log _{10}(\mathrm{CE})$ e $\mathrm{pH}$ (307 amostras)

Figura 21. Semivariograma do $\log _{10}(C E)$

Figura 22. Classes de CE das águas de salinas e baías na Nhecolândia/MS.

Figura 23. Localização das salinas para estudos em escala local: (A) Salina Verde, (B) Salina Grande, (C) Salina Preta e (D) Salina 60 Mil. (Fonte: Imagem Google Earth - 2012)

Figura 24. (a) Salina Verde com destaque do alongamento em forma de divertículo (Fonte: Google Earth), e (b) divertículo quando funciona como pequena salina independente (Foto do autor, 2011)

Figura 25. (a) Salina Preta (b) sedimento escuro do fundo da salina com alguns centímetros de espessura, melhor observado no período de estiagem

Figura 26. (a) Salina Grande e (b) sedimento orgânico do fundo da salina.

Figura 27. Localização da laje (a) e (b) foto da laje que aflora em superfície. 
Figura 28. Curvas de respostas do (a) EM31 e (b) EM38, em função da profundidade efetiva de investigação..

Figura 29. Micro-computador (Allegro DAS70-CX).....

Figura 30. Gama de condutividade elétrica das águas de superfície da Nhecolândia, e a das salinas estudadas. Os pontos pretos representam os valores de CE medidos in situ de 2009 a 2011.

Figura 31. Gamas de pH-Eh observadas nos sedimentos das salinas........

Figura 32. Pontos de medidas da CEa do solo na Salina Verde (EM38DMV em posição vertical).

Figura 33. Histograma dos valores de CEa da Salina Verde (EM38-DMV).

Figura 34. Variograma experimental dos dados de condutividade elétrica aparente (EM38) e a linha em azul, a do modelo ajustado.

Figura 35. Mapa de distribuição da CEa ao redor da Salina Verde.

Figura 36. Mapas da distribuição da condutividade elétrica aparente (CEa) no alongamento SW da Salina Verde: (a) EM38-DMV e (b) EM38-DMH.

Figura 37. Histograma de distribuição dos valores de CEa: (a) EM38DMV e (b) EM38-DMH.

Figura 38. Mapas de distribuição da CEa na porção SW da Salina Verde: (a) EM31-DMV e (b) EM38-DMV; localização da sequência de solo em vermelho.

Figura 39. Localização das sequências de solos (em vermelho) nas Salinas Preta e Grande, 60 Mil e Verde (Fonte: Imagem Google Earth, 2010).

Figura 40. Sequência de solos da Salina Verde com as organizações vertical e lateral dos horizontes e gráfico da distribuição da CEa (EM38-DMV).

Figura 41. Triângulo de textura dos horizontes da sequência de solo da Salina Verde. 
Figura 42. Distribuição do sódio trocável em \% da capacidade de troca..... 100

Figura 43. Distribuição do $\mathrm{pH}\left(\mathrm{H}_{2} \mathrm{O}\right)$ do solo. 101

Figura 44. Sequência de solo entre a Salina Verde, a Cordilheira e a Baía (a); Perfil dos valores de CEa (EM31-DMV) nessa sequência (b).

Figura 45. Distribuição dos valores de CEa ao redor da Salina Preta, e em preto pontilhado variação do nível da água na salina.

Figura 46. Mapeamento EM38-DMV entre a Salina Preta e a Salina Grande. Notar a diferença das respectivas gamas de condutividade elétrica aparente (CEa)..

Figura 47. Sequência de solo passando pela cordilheira e ligando as Salinas Grande e Preta.

Figura 48. Mapeamento EM31-DMV e perfil de solo entre a cordilheira e a Salina 60 Mil

Figura 49. Comparação entre a morfologia dos solos na Salina Verde (presente trabalho) e na Salina do Meio (adaptada de Furquim, 2007).

Figura 50. Distribuição do $\mathrm{pH}\left(\mathrm{H}_{2} \mathrm{O}\right)$ dos solos nas Salinas Verde e do Meio (esta adaptada de Furquim et al., 2010)

Figura 51. Mapas de distribuição dos valores de CEa ao redor das Salinas Verde e do Meio (este adaptado de Barbiéro et al., 2008).

Figura 52. Morfologia de solos das cordilheiras contíguas às Salinas Verde e do Meio (esta adaptada de Barbiéro et al., 2008).........

Figura 53. Modelo de funcionamento hidrológico da salina e gênese das ondulações dos horizontes endurecidos profundos (adaptado de Barbiéro et al., 2008).

Figura 54. Modelo de funcionamento hidrológico em função da altura da soleira $(Q$ : Volume anual de água que atravessa a soleira, ETP: Evapotranspiração anual, P: Precipitação anual) 
Figura 55. Modelo de funcionamento hidrológico de salinas e a distribuição do $\log _{10}(\mathrm{CE})$.

Figura 56. Ilustração da sonda protegida dentro de cano PVC instalada na Salina Verde.

Figura 57. Dados de monitoramento durante um ano hidrológico na Salinas Verde de setembro/2010 a outubro/2011

Figura 58. Morfologia da cobertura pedológica ao redor da Salina Verde e funcionamento interanual da salinidade.

Figura 59. Modelo de Funcionamento Hidroquímico de "Estruturas em Patamares"

Figura 60. Mapa de distribuição das principais unidades da paisagem da Nhecolândia/MS. 


\section{LISTA DE TABELAS}

Tabela 1. Estatística descritiva das variáveis (Amostragens I e II $=147$ amostras)

Tabela 2. Matriz de correlação das variáveis (147 amostras)..................... 53

Tabela 3. Análise em componentes principais - valores próprios............... 53

Tabela 4. Estatística descritiva............................................................... 60

Tabela 5. Classes de condutividade elétrica $\left(\log _{10}(\mathrm{CE})\right) \ldots \ldots \ldots \ldots \ldots \ldots \ldots \ldots \ldots . . . . . . . . . .62$

Tabela 6. Gamas de CE e pH identificadas na Baixa Nhecolândia............. 65

Tabela 7. Localização e condutividade elétrica das 4 salinas 70 selecionadas.

Tabela 8. Características físico-químicas das salinas nos períodos secos, de abril a setembro $(2009,2010$ e 2011) e, úmido de outubro a março (2010).

Tabela 9. Relação condutividade máxima e mínima, e pH máximo e mínimo das águas das salinas de setembro de 2009 a julho de 2011

Tabela 10. Estatística descritiva

Tabela 11. Valores de CEa na sequência de solos da Salina Verde.

Tabela 12. Variáveis selecionadas para o ensaio de tipologia envolvendo as Salinas Grande, Verde, 60 Mil e Preta.

Tabela 13. Ensaio de Tipologia: Tipo 1 Salina Preta e Tipo 2 Salina Verde, e suas características 


\section{LISTA DE FOTOS}

Foto 1. (a) Lagoa da Nhecolândia; (b) "Ilha" com lagoa no centro do Delta do Okavango, (Bauer et al., 2006).

Foto 2. Salina Verde nos períodos: (a) úmido e (b) seco com borbulhamentos.

Foto 3. Salina Preta nos períodos: (a) seco e (b) úmido............................... 72

Foto 4. Salina Grande nos períodos: (a) seco e (b) úmido............................ 74

Foto 5. (a) Salina 60 Mil no período seco de setembro/2009 e (b) sedimento orgânico do fundo da salina recoberto por florescência de sais (em branco).

Foto 6. Coleta de amostra da laje (a) e (b)

Foto 7. Aquisição de dados de CEa do solo com os aparelhos (a) EM38MK2 e (b) EM31-MK2

Foto 8. Extração da matéria orgânica (a) e pipetagem (b)

Foto 9. Da esquerda para direita, os aparelhos: Condutivímetro, Ehmêtro, pHmêtro, Turbidímetro e Oxímetro

Foto 10. (a) e (b) Sonda instalada na Salina Verde no final da estação seca (Setembro/2010)

Foto 11. (a) Retirada da sonda para leitura dos dados, (b) divertículo da Salina Verde (visão sentido SW-NE) após grande cheia (Julho/2011). 


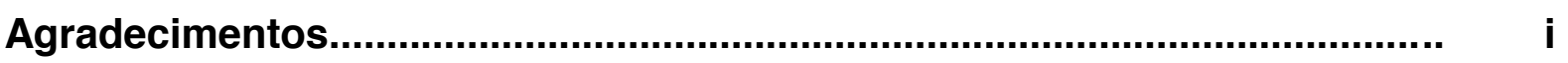

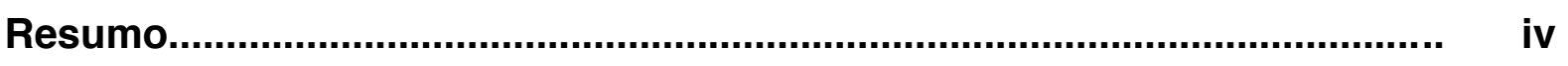

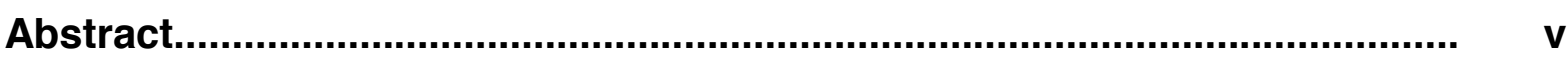

Résumé............................................................................................ vi

Lista de Figuras.................................................................................. vii

Lista de Tabelas.......................................................................................

Lista de Fotos............................................................................................. xiii

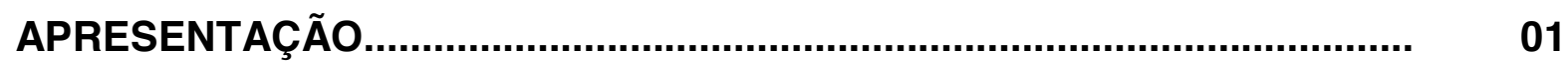

CAPÍTULO I. SISTEMAS LACUSTRES NO BRASIL E O PANTANAL (MS)

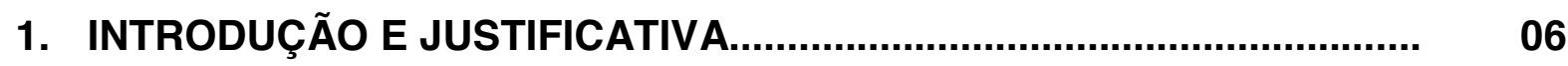

2. QUADRO GEOGRÁFICO............................................................... 09

2.1 Geologia e Geomorfologia........................................................... 11

2.1.1. Os Pantanais............................................................................ 14

2.1.2. A Nhecolândia................................................................... 15

2.2. Clima e Hidrografia...................................................................... 18

2.3. Solos e Vegetação........................................................................ 20

2.4 A Nhecolândia no quadro hidroquímico da Bacia do alto Paraguai.... 23

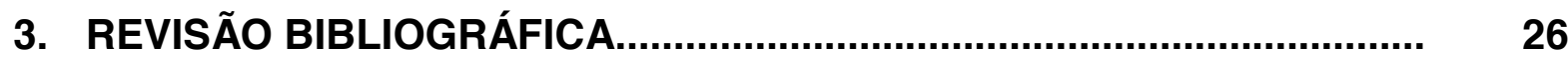

3.1. Regiões de lagos no mundo.......................................................... 28

3.2. Sistemas lacustres no Brasil....................................................... 31

3.3. Sistemas lacustre da Nhecolândia.................................................. 32 
3.4. Sistemas lacustres e leques aluviais.............................................. 35

4. CONSIDERAÇÕES GERAIS......................................................... 40

5. OBJETIVOS..................................................................................... 42

\section{CAPÍTULO II. AS ÁGUAS DA NHECOLÂNDIA}

1. MATERIAIS E MÉTODOS............................................................

1.1. Área de estudo e aquisição de dados................................................ 44

1.2. Tratamento dos dados............................................................. 47

1.2.1. Análise em Componentes Principais (ACP)............................. 47

1.2.2. Tratamento geoestatístico......................................................... 48

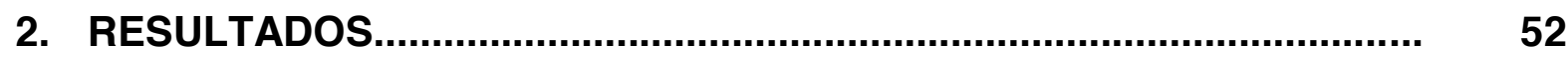

2.1. Estatística Descritiva................................................................... 52

2.2. Matriz de Correlação.................................................................... 52

2.3. Eixos Fatoriais .............................................................................. 53

2.4. Diagramas de concentração............................................................. 55

3. DISCUSSÃO DOS RESULTADOS.................................................... 57

3.1. Distribuição estatística das amostragens I, II e III.............................. 57

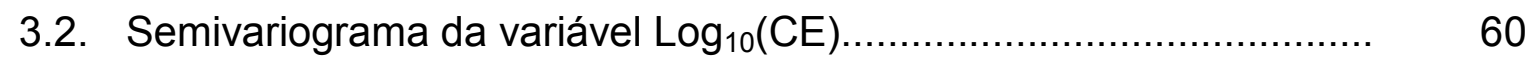

3.3. Expressão espacial da distribuição................................................... 61

4. CONSIDERAÇÕES GERAIS........................................................... 64

4.1. Elevadas gamas de condutividade elétrica e $\mathrm{pH}$............................... 65

4.2. Alcances baixos e distribuição bimodal da variável $\log _{10}(\mathrm{CE})$........... $\quad 67$ CAPÍTULO III. MORFOLOGIA DE SALINAS NA NHECOLÂNDIA

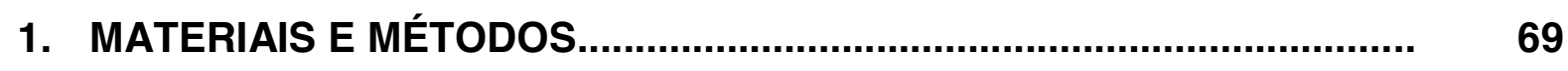

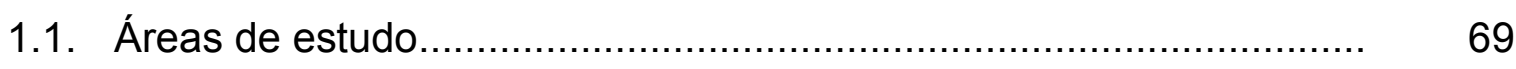


1.1.1. Salina Verde.......................................................................

1.1.2. Salina Preta.......................................................................... 72

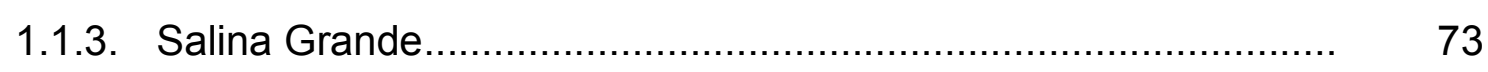

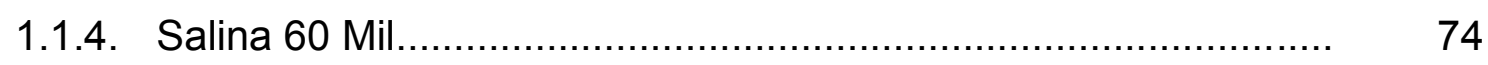

1.2. Mapeamento por indução eletromagnética (EM38 e EM31).............. 76

1.2.1. Equipamentos e funcionamento............................................... 76

1.2.2. Procedimentos de aquisição dos dados....................................... 79

1.2.3. Tratamento dos dados............................................................ $\quad 80$

1.3. Morfologia dos solos e caracterização físico-química dos constituintes e das águas.

2. RESULTADOS.

2.1. Características físico-químicas das águas e dos sedimentos das salinas.

2.1.1. Gama de condutividade elétrica das águas.................................. 85

2.1.2. Oxigênio dissolvido e condições redox nas águas e sedimentos. 86

2.2. Mapeamento da CEa dos solos ao redor da Salina Verde................. 87

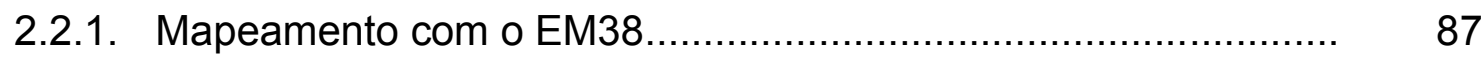

2.2.2. Comparação entre os mapeamentos EM38 Dipolos Magnéticos Vertical (DMV) e Horizontal (DMH) ......................................

2.2.3. Mapeamento com o EM31 ….................................................. 93

2.3. O solo na Salina Verde.................................................................... 94

2.3.1. Características morfológicas e físico-químicas do solo................ 95

2.3.2. Morfologia e condutividade elétrica aparente do solo.................. 101

2.4. Morfologia e condutividade elétrica aparente dos solos na

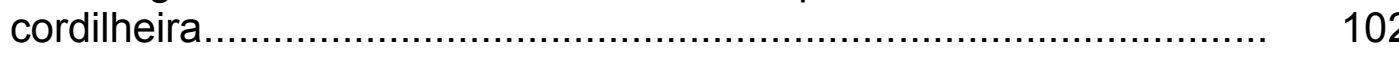

2.5. Morfologia e CEa dos solos das outras salinas................................. 104

2.5.1. Salina Preta.......................................................................... 104 
2.5.2. Salina Grande..................................................................... 105

2.5.3. Morfologia do solo das Salinas Grande e Preta.......................... 106

2.5.4. Salina 60 Mil........................................................................... 108

3. DISCUSSÃO.............................................................................. 110

3.1. Sistema representativo da Nhecolândia.......................................... 110

3.1.1. Similaridades morfológicas....................................................... 110

3.1.2. Similaridades físico-químicas .................................................... 113

3.1.3. Similaridades funcionais.......................................................... 115

4. CONSIDERAÇÕES GERAIS..............................................................

CAPÍTULO IV. FUNCIONAMENTO HIDROLÓGICO E TIPOLOGIA DE SALINAS.

1. MODELO DE FUNCIONAMENTO HIDROLÓGICO................................... 120

1.1. Funcionamento hidrológico da Salina do Meio................................... 121

1.2. Abrangência do modelo................................................................... 123

1.3. Adequação do modelo de funcionamento aos dados coletados......... 125

2. FUNCIONAMENTO SAZONAL DA SALINA VERDE............................... 127

2.1. Monitoramento, aquisição e tratamento dos dados............................ 127

2.2. Resultados do monitoramento da água............................................. 129

2.3. Discussão dos resultados ............................................................... 133

2.3.1. Funcionamento interanual...................................................... 133

2.3.2. Variabilidade sazonal de salinidade .......................................... 134

3. TIPOLOGIA DE SALINAS.............................................................. 137

3.1. Critérios para uma tipologia........................................................... 139

3.1.1. Critérios morfológicos regionais................................................ 139

3.1.2. Critérios físico-químicos e morfológicos das salinas.................... 143 
3.2. Ensaio de tipologia................................................................ 146

4. CONSIDERAÇÕES GERAIS......................................................... 148

CONCLUSÃO GERAL................................................................. 150

REFERÊNCIAS BIBLIOGRÁFICAS.............................................. 158 
APRESENTAÇÃO 
No atual contexto do chamado aquecimento global percebe-se um esforço da comunidade científica para incorporar, nos modelos climáticos globais, a complexidade dos meios naturais. Nesse quadro, muitas pesquisas têm sido dirigidas aos estudos dos ciclos biogeoquímicos, com ênfase na identificação, e quantificação, dos processos que controlam o ciclo global do carbono, tais como: (i) velocidade de alteração das rochas submetidas à ação de diversos tipos de climas; (ii) transferências de carbono, e de outros elementos químicos, dos continentes para os oceanos; e (iii) processos que favorecem os fluxos de carbono para a atmosfera, tanto em ambientes continentais quanto marinhos (Nils-Axel e Etiope, 2002, Dessert et al., 2003, Roelandt et al., 2006, Kardjilov et al., 2006, Pokrovsky et al., 2006, Jha et al., 2009; Martinelli et al., 2009).

Muitos desses trabalhos ressaltam a importância das áreas úmidas continentais no estoque, transformação e transferência de elementos químicos orgânicos ou inorgânicos, dissolvidos, particulados ou gasosos (Tundisi et al., 1999; Lerman et al., 2007; Dupré et al., 2003; Tundisi et al., 2008). No entanto, os balanços regionais desses ciclos são ainda desequilibrados por falta de quantificação adequada abrangendo a grande diversidade de ambientes, ou reservatórios, que existem no planeta, aqui inserindo as áreas úmidas de grandes dimensões (Barroux et al., 2006; Martinelli et al., 2009).

O Pantanal Mato-grossense é considerado a maior área úmida continental do planeta, uma planície de aproximadamente $135.200 \mathrm{~km}^{2}$ (Por, 1995), foco de muitas pesquisas que visam compreender o seu funcionamento ecológico como base para sua proteção. Recentemente, delineou-se uma compartimentação do Pantanal baseada na composição química das águas dos rios, e nas interações água-solo (Rezende Filho, 2011). Dentre as várias regiões mapeadas destaca-se a 
Nhecolândia, cuja maior peculiaridade é a presença de aproximadamente 10.000 lagoas (Fernandes, 2007), entre salinas e lagoas de água doce a coexistir lado a lado, numa paisagem intersectada por canais fluviais perenes e intermitentes. Tanto a origem quanto o funcionamento hidro-biogeoquímico dessas lagoas têm sido objeto de muitas hipóteses, ainda não confirmadas.

O desenvolvimento de qualquer tipo de balanço regional, seja de emissão de gás, seja de fluxos de elementos dissolvidos e de sequestro de carbono, dentre outros, confronta-se com a forte variabilidade química das águas de superfície da Nhecolândia (Barbiéro et al., 2002, 2008), que reflete, provavelmente, diferentes funcionamentos biogeoquímicos dos ambientes (Mariot et al., 2007). Estima-se que duas etapas são necessárias antes de extrapolar para a região, os resultados de medidas feitas localmente. Trata-se, de um lado, de estabelecer uma tipologia detalhada das lagoas existentes na região, sobretudo das salinas; de outro, da quantificação desses tipos de lagoas e da área de trocas que representam.

Se o sensoriamento remoto se mostra uma ferramenta apropriada para a segunda etapa, a primeira pressupõe aquisição de dados locais medidos in situ no campo, a fim de: (I) identificar eixos de variabilidade química das águas, (II) entender a distribuição desses eixos de variabilidade no espaço e no tempo, (III) identificar os processos responsáveis por essa variabilidade, e (IV) compreender suas influências no funcionamento hidrobiogeoquímico das lagoas.

Estes quatro pontos formam a estrutura deste trabalho de doutorado, que está dividido em quatro capítulos:

O primeiro capítulo corresponde a uma apresentação do quadro geral da área, e inclui um levantamento bibliográfico de alguns aspectos ligados ao tema de estudo. 
O segundo capítulo procura identificar, e quantificar, os eixos de variabilidade química das águas superficiais, com base no estudo das características físico-químicas das águas e análises multivariadas. Este estudo é complementado por uma análise da distribuição espacial desses eixos, a partir de tratamentos geoestatísticos das variáveis numéricas relevantes.

Os resultados do segundo guiam o terceiro capítulo, numa tentativa de identificar, em escala local, os processos responsáveis pela variabilidade e sua distribuição espacial. Para isto foram feitas observações diretas da cobertura pedológica, e indiretas pelo seu mapeamento por métodos geofísicos de subsuperfície.

O quarto capítulo corresponde a uma síntese do funcionamento hidrológico das salinas, com base no estudo da variabilidade química temporal da água, e pelo monitoramento de uma salina durante um ano hidrológico completo. Ele também é dedicado a um ensaio de tipologia de salinas, a partir dos quatro exemplares estudados nesta pesquisa.

Este trabalho foi realizado dentro de um quadro maior de pesquisas financiadas pela FAPESP (Projetos n²008/09086-7 e 2011/12770-0), com bolsa de estudo pelo CNPq (Processo N 141808/2009-8). 
CAPÍTULO I

SISTEMAS LACUSTRES NO BRASIL E O PANTANAL DA NHECOLÂNDIA (MS) 


\section{INTRODUÇÃO E JUSTIFICATIVA}

O continente sul americano, especialmente o Brasil, apresenta uma das maiores reservas de águas interiores do Planeta, ligadas aos grandes rios e suas extensas áreas de várzeas, e às inúmeras áreas alagadas e lagos rasos permanentes ou temporários. $\mathrm{O}$ total dessas áreas alagadas, temporárias e permanentes, em todas as regiões tropicais e subtropicais brasileiras é da ordem de 1 milhão de $\mathrm{km}^{2}$ (Tundisi et al., 1999). Os lagos são considerados um dos mais acessíveis recursos hídricos, componentes essenciais dos balanços regional e global de água no planeta (Meybeck, 1995).

Os sistemas lacustres são muito comuns no Brasil. Eles são frequentes nos grandes sistemas de águas interiores, mas também nas zonas limítrofes entre planaltos e planícies costeiras (Wilhelmy, 1958; Pflug, 1969; Mousinho Meis, 1977; Melack, 1984; Mousinho de Meis e Tundisi, 1984; Sieppel, et al., 1992; Junk e Silva, 1995; Esteves, 1998; Silveira, 1998; Tundisi et al., 1999; Sperling, 1999; Assine, 2003; Ab'saber, 2006; França, 2007; Brighenti, 2009; Arruda Justiniano, 2010). A maioria desses sistemas se formou por processos fluviais, e se localiza nas planícies de rios de médio a grande porte, dos quais os principais são o Amazonas-Solimões, Paraguai, Doce, dentre outros (Costa et al., 2007).

No Brasil, os estudos dos sistemas lacustres estiveram sempre calcados em questões paleo-ambientais e paleogeográficas, de interesse de vários ramos da geologia, mas também da geomorfologia. Nesta se destacam inúmeros trabalhos de morfologia fluvial, onde os lagos aparecem apenas como produtos, ou formas da ação fluvial, das quais as mais valorizadas foram os terraços (Ab'Sáber, 1957; Ab'Sáber, 1966; Christofoletti, 1974; Penteado, 1978; Latrubesse e Stevaux, 2006; 
França et al., 2008), e algumas exceções (Wilhelmy, 1958; Mousinho de Meis, 1977; 1979; Mousinho de Meis e Moura, 1984).

Cabe, contudo, lembrar que do Séc. XVIII até o início do Séc.XX o conhecimento produzido sobre lagos foi essencialmente feito por geógrafos, sobretudo geomorfólogos (Meybeck, 1995). Dentre tais trabalhos se destacam as pesquisas de Penk (1894) dedicadas ao inventário e estudo de tipos de lagos e suas morfologias (Meybeck, 1995; Lerman et al., 1995).

Dada a importância ambiental crescente dessas unidades morfológicas na paisagem, esse tema foi resgatado por outras áreas do conhecimento, especialmente a limnologia, ecologia, química, física, biologia, geologia, dentre outras (Meybeck, 1995). Hoje são essas disciplinas que têm produzido o maior volume de conhecimentos sobre os sistemas lacustres brasileiros, inclusive sobre suas morfologias (Melack, 1984; Sieppel et al., 1992; Esteves, 1998; Soffiati, 1998; Panosso et al., 1998; Sperling, 1999; Tundisi, 2008), e das influências da morfologia sobre o comportamento ambiental e limnológico dos lagos (Melack, 1984; Mousinho de Meis e Tundisi, 1986; Junk, 1997; Furch e Junk, 1997; Melack e Forsberg, 2001).

O Pantanal da Nhecolândia se situa no compartimento sul do leque aluvial do Taquari. Esse setor comporta um sistema hídrico bastante complexo em que há, ao mesmo tempo, superposição e justaposição de um sistema lacustre de grande porte, e de um sistema de drenagem mais ou menos aberto. Essa fisiografia enquadra esse sistema nas chamadas áreas úmidas continentais, "wetland", caracterizadas pelas flutuações do nível da água e pelas oscilações entre fases terrestre e aquática que apresentam (Junk e Silva, 1995). Este não é o único ponto relevante dessa área, a ele se soma o fato do sistema lacustre da Nhecolândia apresentar lagoas salinas contíguas a lagoas de água doce (Barbiéro et al., 2002). 
Estima-se que somente na Baixa Nhecolândia esse sistema lacustre comporte cerca de 9924 lagoas, repartidas entre pequenas (6497), médias (2804) e grandes (623), sendo a maioria de água doce, e a minoria de água salgada. Do total da área mapeada, $10,5 \%$ corresponde às lagoas de água doce, 1,2\% às salinas, $32 \%$ às cordilheiras e $56,3 \%$ às vazantes (Fernandes, 2007). A formação desse sistema, e principalmente, a origem da salinidade, ainda não foram elucidadas (Barbiéro et al., 2002; Assine, 2003). Contudo, trabalhos mais recentes abriram novos caminhos para pesquisá-las, calcados em métodos geofísicos, geoquímicos, biogeoquímicos e pedológicos (Barbiéro et al., 2002; 2008; Mariot et al., 2007; Furquim et al., 2008; 2010b).

Se os trabalhos realizados até agora produziram uma primeira tipologia dessas lagoas, diferenciando-as em duas grandes categorias, lagoas de água doce, ou baías, e lagoas de água salgada, ou salinas (Fernandes, 2007), nenhuma tipologia foi ainda dedicada às salinas. Este fato justifica o presente trabalho, e define o seu objetivo geral que é compreender a distribuição espacial da salinidade no sistema lacustre da Nhecolândia.

Este trabalho constitui um pré-requisito básico para futuras pesquisas dirigidas não apenas às questões de origem da salinidade dessas lagoas, e desse sistema lacustre como um todo, mas também do funcionamento hidrobiogeoquímico das salinas nessa paisagem. Em última instância, uma forma de resgate desse tema para o âmbito atual da Geografia Física. 


\section{QUADRO GEOGRÁFICO}

A Bacia do Alto Paraguai integra o grande sistema hidrológico ParaguaiParaná-Prata, com uma via fluvial de 4.827 .000 Km (Alvarenga et al., 1984), que drena a Bacia do Prata com uma área de $3.100 .000 \mathrm{Km}^{2}$ repartidas pelo Brasil, Bolívia, Argentina, Paraguai e Uruguai (Tundisi et al., 1999). Nesse sistema, chamado de Platino, se destaca o Pantanal, situado nas coordenadas $14^{\circ} \mathrm{S} / 59^{\circ} \mathrm{W}$ e $22^{\circ} \mathrm{S} / 53^{\circ} \mathrm{W}$.

No Brasil, o Pantanal se localiza nos Estados de Mato Grosso e Mato Grosso do Sul, com uma área de aproximadamente $135.000 \mathrm{~km}^{2}$ (Figura 1). A Nhecolândia, uma das maiores sub-regiões do Pantanal, se situa no comportamento sul do Leque Aluvial do Taquari, entre os rios Taquari e Negro.

A presente pesquisa foi desenvolvida na Nhecolândia, principalmente em sua porção sul, próxima ao Rio Negro numa área situada ao Norte de Aquidauana (MS). 


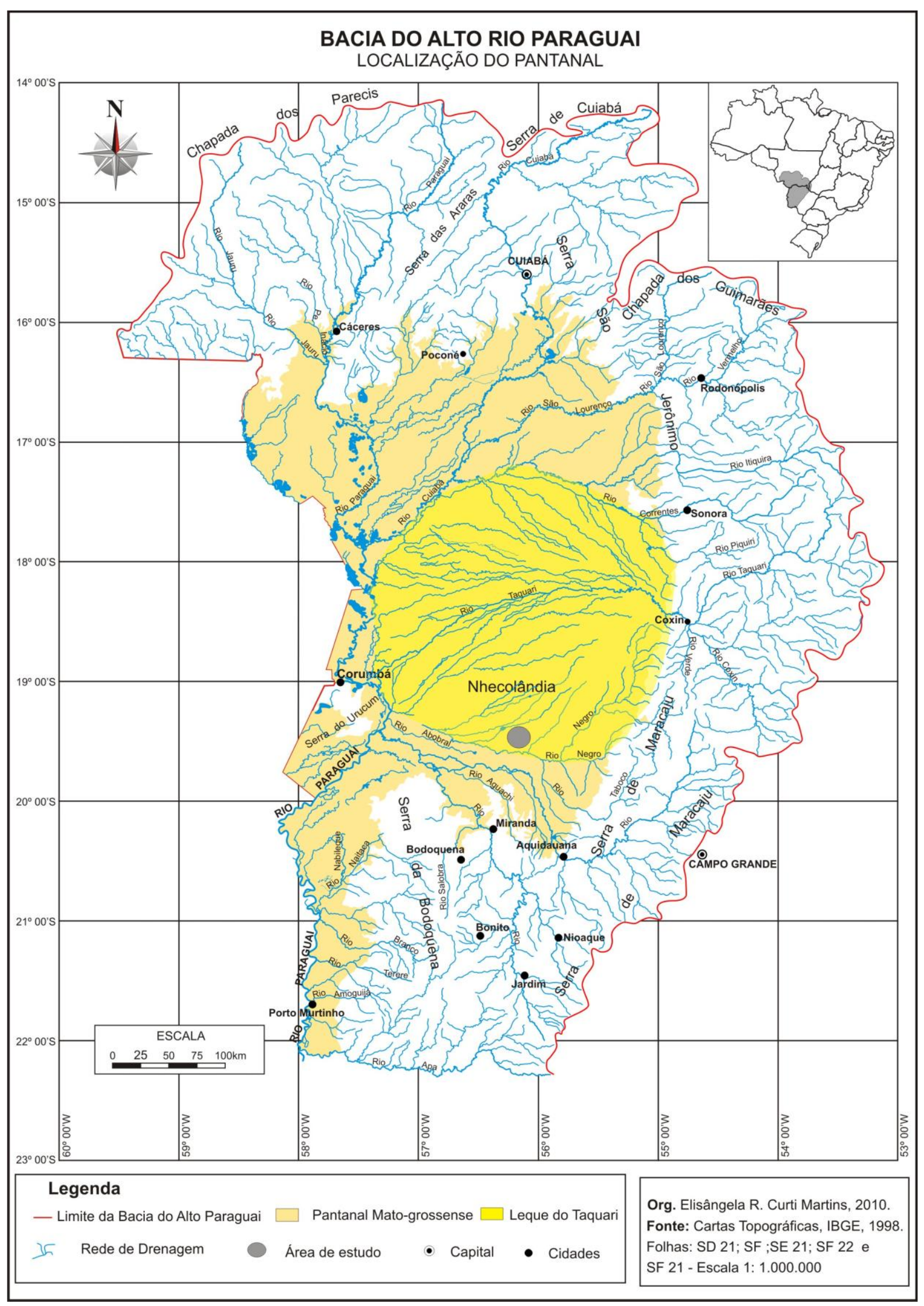

Figura 1. Localização do Pantanal Mato-grossense na Bacia do Alto Paraguai. 


\subsection{Geologia e Geomorfologia}

A Bacia do Alto Paraguai (BAP) apresenta três grandes unidades geomorfológicas (Figura 2) delimitadas por faixas de altitudes, a saber: os Planaltos, entre 250 e 1065 m, a Depressão Periférica, entre 150 e 250 m, e a Planície e Pantanais Mato-grossenses, entre 80 e 150 m (Alvarenga et. al., 1982; Barros, et. al., 1982; Del'Arco, 1982; 2004; Franco e Pinheiro, 1982; RadamBrasil, 1984; Godoi Filho, 1986).

As unidades "Planaltos" e "Depressão Periférica" contornam, em toda sua extensão, a unidade "Planície e Pantanais Mato-grossenses". Os Planaltos são mais estreitos e bastante recortados ao norte e ao sul da bacia, e mais largos a leste. Ao contrário, a Depressão Periférica é mais desenvolvida e extensa ao norte e ao sul, e muito estreita a leste, onde localmente pode estar restrita às escarpas dos Planaltos (RadamBrasil, 1984; Rezende Filho, 2011).

Essa configuração geral da morfologia da Bacia do Alto Paraguai é concordante com os modelos geológicos e geotectônicos que a consideram como uma depressão tectônica interior (Almeida, 1945; Ruellan, 1952 apud Ab'Sáber, 1988). Apesar da geologia dessa área ainda apresentar lacunas do ponto de visto tectônico, cronoestratigráfico, paleogeográfico, e sedimentar (Assine, 2003), há um consenso sobre os eventos que interviram em sua formação. Tais eventos são ligados ao soerguimento do Geossinclíneo Andino no Terciário Superior, Neogeno, responsável por abatimentos de áreas marginais como as do Chaco e do Pantanal. Os processos de subsidência que afetaram o arcabouço estrutural da depressão não são apenas de ordem flexural, mas também extensional (Shiraiwa, 1994; Ussami, 1999; Almeida et al., 2006). Há registros de atividades neotectônicas no Pantanal Mato-grossense, e falhas associadas ao Lineamento Transbrasiliano, com direção 
NE-SW, que vai da Bacia do Chaco, no Paraguai, atravessa obliquamente o

Pantanal e vai até o Nordeste do Brasil (Shiraiwa, 1994; Ussami et al., 1999; Assine, 2003).

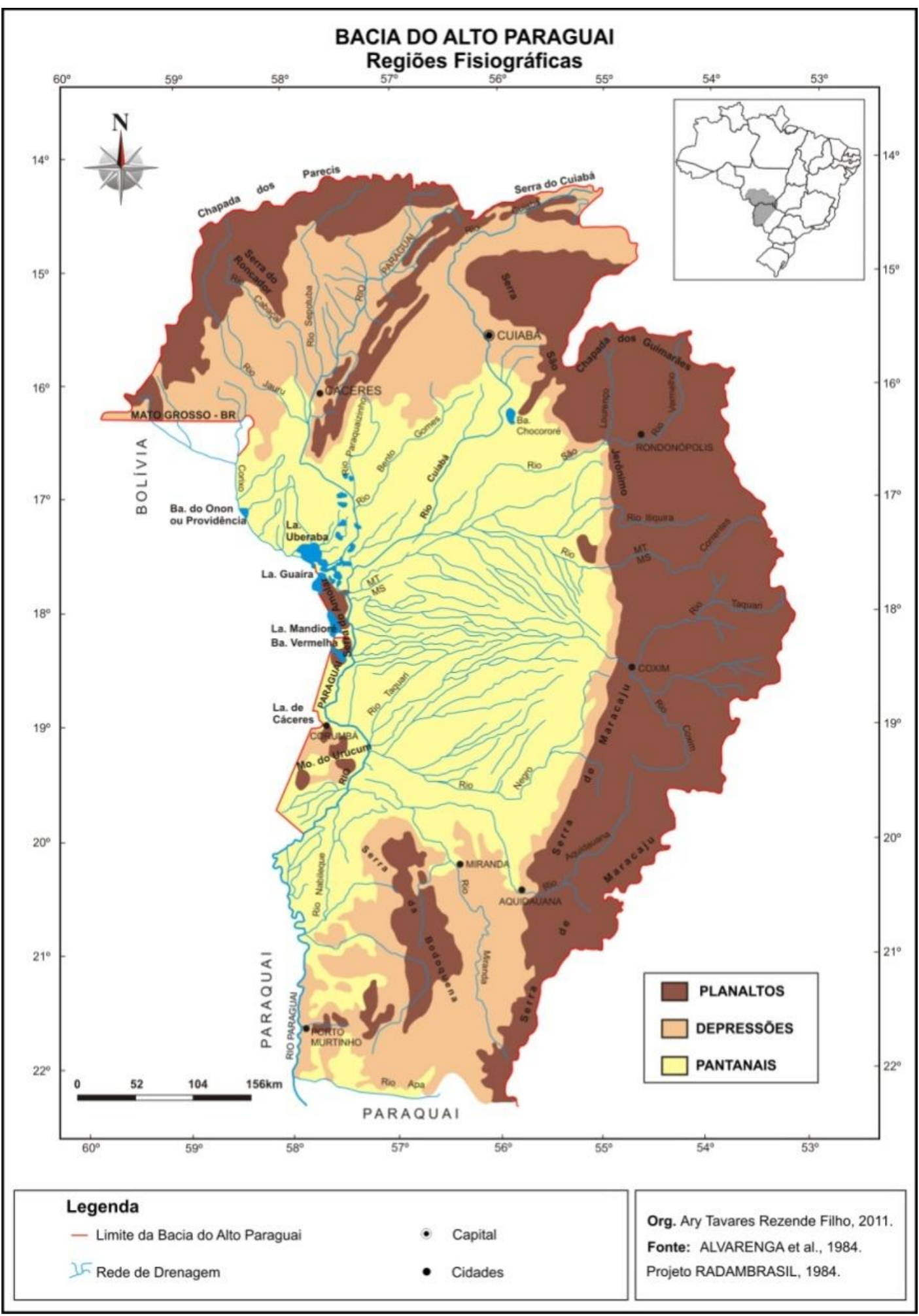

Figura 2. Regiões Fisiográficas da Bacia do Alto Paraguai (Fonte: Rezende Filho, 2011). 
Estima-se que a partir do Neocenozóico as áreas abatidas passaram a sofrer assoreamento, em vigor até hoje, fazendo do Pantanal um extenso trato de sistemas deposicionais (Almeida, 1945; RadamBrasil, 1982; Ab'Saber, 1988; Assine, 2003). Com base em dados sísmicos, calcula-se que a espessura máxima do embasamento sedimentar é de 550 metros, e a taxa de subsidência estimada para o Quaternário é de $22 \mathrm{~cm} / 1000$ anos (Ussami et al., 2000).

Em síntese, a geologia da Depressão do Alto Paraguai e seu entorno, se distingue por formações predominantes do Pré-Cambriano Superior situadas sob extensos depósitos Quaternários, com afloramentos rochosos expressivos favorecidos por falhas (Almeida, 1945, Projeto Radambrasil, 1982 a e b, Godoi Filho, 1986, Shiraiwa, 1994).

Ao norte da Bacia do Alto Paraguai aparecem principalmente rochas PréCambrianas dos Grupos Alto Paraguai e Corumbá, e rochas Mesozóicas areníticas do Grupo Parecis. Nessa porção se destacam os planaltos, que compõem o grande divisor de águas com a bacia Amazônica, isto é, o Planalto dos Parecis, a Província Serrana e o Planalto dos Guimarães. Este último é formado, a oeste, centro e extremo nordeste, de arenitos da Formação Furnas, e litologias Detrítico-Lateríticas do Terciário-Quaternário. No centro, os arenitos vermelhos se intercalam com siltitos, folhelhos, conglomerados e diamictitos da Formação Aquidauana, e a oeste, a Formação Ponta Grossa apresenta intercalações de siltitos, arenitos e folhelhos do Grupo Paraná.

Em sua borda leste, sobre rochas cristalinas pré-cambrianas ocorrem sequências paleozóicas e mesozóicas da Bacia do Paraná. Neste setor, os Planaltos Taquari-Itiquira e Maracaju-Campo Grande formam o grande divisor de águas com a Bacia do Paraná. 
Em sua porção sul predominam rochas graníticas do Pré-Cambriano Inferior e Superior; e rochas carbonáticas do Grupo Corumbá, com a presença local de calcários. Neste setor da bacia, o Planalto da Bodoquena compreende um conjunto de relevos residuais dispostos na direção norte-sul, e localmente relevos cársticos.

Na borda oeste, e em discordância com os metamorfitos do Grupo Cuiabá, ocorrem rochas neo-proterozóicas pouco deformadas do Grupo Corumbá, com livre inclinação sub-horizontal para sudoeste, constituindo os Planaltos Residuais de Urucum-Amolar e do Alto Guaporé (Alvarenga, et. al, 1982; Del'Arco, 1982; Godoi Filho, 1986).

A unidade Depressão Periférica apresenta extensas superfícies aplainadas, com trechos em forma de pedimentos muito dissecados, com topos planos a convexos e localmente em cristas (Franco e Pinheiro, 1982; Alvarenga et al., 1982 e 1984).

A unidade Planície e Pantanais Mato-Grossense corresponde às planícies de inundação dos rios, e aos vários pantanais que se diferenciam nessa planície pelas extensões de áreas alagáveis associadas às sub-bacias do Rio Paraguai, como a do Nabileque, Taquari, São Lourenço, Aquidabã, Branco, Apa, Miranda e Negro (RadamBrasil,1982).

\subsubsection{Os Pantanais}

O embasamento do Pantanal é constituído por rochas metamórficas de baixo-grau, e magmáticas neo-proterozóicas do Grupo Cuiabá. O seu preenchimento é composto principalmente por sedimentos siliciclásticos, sendo que o empilhamento estratigráfico apresenta um afinamento para o topo. $\mathrm{Na}$ parte 
inferior do empilhamento predominam conglomerados e arenitos grossos, e na superior, areias quartzosas finas a médias, localmente grossas. Em vários níveis ocorrem intervalos com cores avermelhadas ligadas a óxido de ferro como cimento, eventualmente lateritas (Assine, 2003).

Os Pantanais apresentam extensas superfícies de acumulação recortadas por uma complexa rede de drenagem comandada pelo rio Paraguai, frequentemente sujeita a inundações (Alvarenga, 1984, Assine, 2003). Nesta unidade são comuns os leques aluviais, dos quais o do Taquari é o mais notável. A sedimentação atual ocorre nas áreas sujeitas a grandes inundações, principalmente nas bordas dos leques do Cuiabá, do São Lourenço e do Taquari, e na planície do Rio Paraguai (Assine, 2003; Facincani et al., 2006; Zani et al., 2006; Zani e Assine, 2009; Corradini et al., 2009).

Dada sua grande biodiversidade o Pantanal é considerado um dos principais biomas brasileiros. Nele são reconhecidos diversos pantanais, cada um com características próprias. Com base nessas características, Silva e Abdon (1998) dividiram o Pantanal em diferentes sub-regiões (Figura 3).

Dessas sub-regiões, neste trabalho se destaca a Nhecolândia, uma das maiores sub-regiões do Pantanal, limitada ao norte pelo rio Taquari e ao sul pelo rio Negro, a leste pelas escarpas da Serra de Maracaju, e a oeste pelo Rio Paraguai. Ela ocupa todo compartimento sul do leque aluvial do Rio Taquari (Figura 3).

\subsubsection{A Nhecolândia}

Na Nhecolândia, observam-se feições morfológicas muito peculiares (Figura 4), cuja terminologia, tipicamente regional, é classificada como; "baías", "cordilheiras", "vazantes" e "corixos" (Radambrasil, 1982a). 


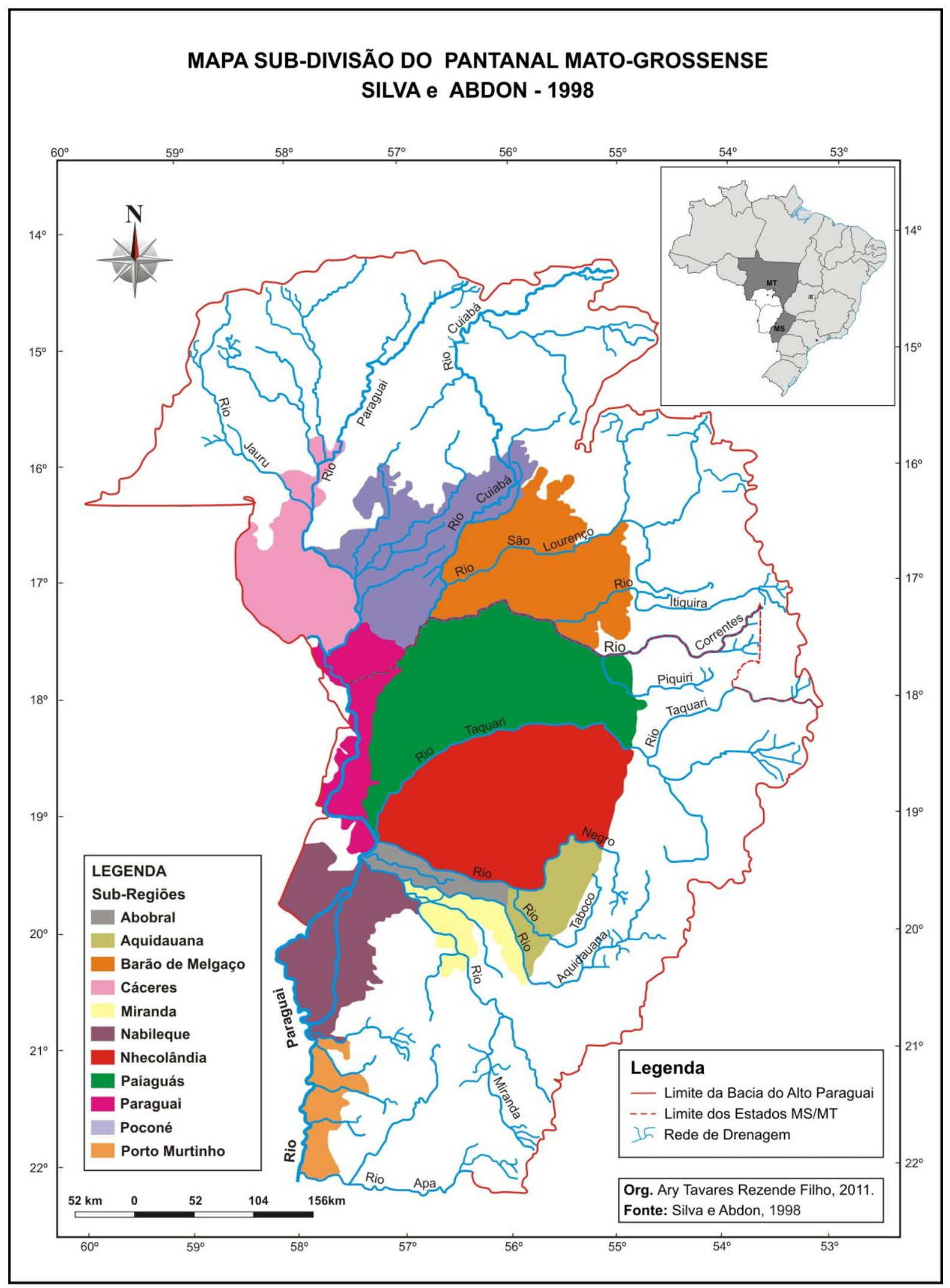

Figura 3. Sub-regiões do Pantanal Mato-grossense de Silva e Abdon (1998), (Fonte: Rezende Filho, 2011). 
Segundo essa terminologia, "baías" constituem áreas deprimidas com água, às vezes salobras, de forma circular, semicircular ou irregular, e variam de dezenas a centenas de metros. As "cordilheiras" são pequenas elevações do terreno situadas entre duas "baías", em média com 2 m acima do espelho de água.

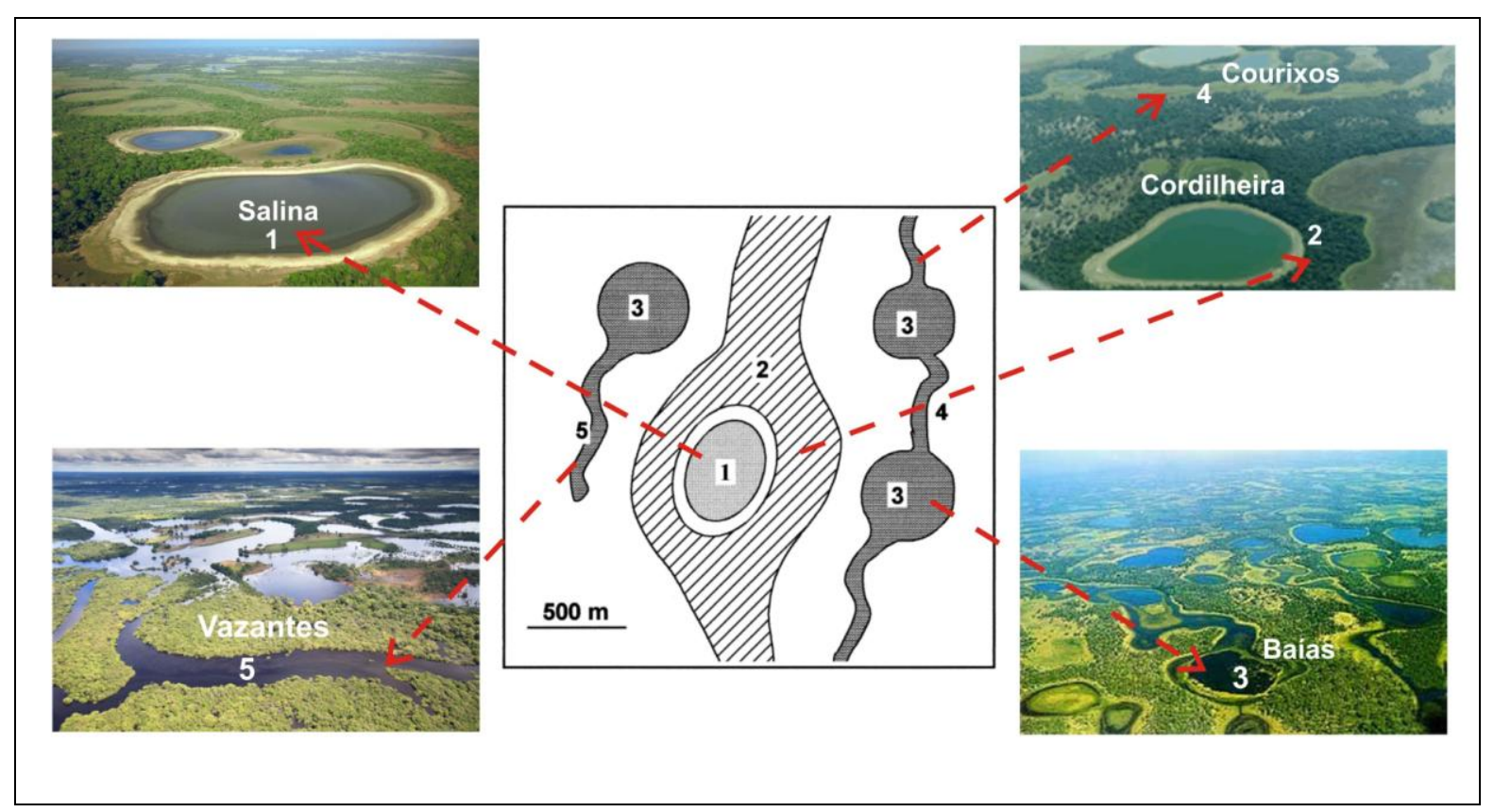

Figura 4. Principais feições da paisagem da Nhecolândia (Fonte: Barbiéro et al., 2002).

As cordilheiras representam áreas quase nunca alagadas, sendo atingidas somente em cheias muito excepcionais. As "vazantes" compreendem as amplas depressões situadas entre as "cordilheiras". Na época de cheia essas depressões servem de escoadouro entre as "baías", adquirindo o caráter de curso fluvial intermitente, com vários quilômetros de extensão. Os "corixos" correspondem a pequenos cursos de água, de caráter perene, conectando "baías" contíguas. Esses cursos comparados às "vazantes" possuem maior poder erosivo, e a incisão é muito maior no sentido linear, originando canais estreitos e mais profundos (Radambrasil, 1982a). 


\subsection{Clima e Hidrografia}

O centro-oeste brasileiro é considerado um centro térmico de baixa pressão no Continente Sul-Americano. Nessa região, a Bacia do Alto Paraguai é fortemente influenciada por massas de ar equatorial e tropical. Ao longo do ano, ela sofre a influência das altas pressões do Anticiclone Subtropical do Atlântico Sul (ASAS), que é responsável pela estação seca no outono e inverno, e também a da Zona de Convergência Intertropical (CIT) responsável pela estação chuvosa na primavera e verão (Nimer, 1989).

Desse modo, o clima do Pantanal é considerado tipicamente tropical com duas estações alternadas, uma seca de abril a setembro, e a outra úmida de outubro a março, correspondente ao tipo Aw da classificação de Köppen. As temperaturas médias oscilam entre $23^{\circ} \mathrm{C}$ e $25^{\circ} \mathrm{C}$, sendo que as menores temperaturas ocorrem nos Planaltos, e as maiores nos Pantanais (Alvarenga et al., 1984, Por, 1995).

O domínio de altas temperaturas no Pantanal se deve à sua localização na faixa tropical, entre $16^{\circ}$ e $22^{\circ} \mathrm{S}$, e à sua distância, de aproximadamente $1500 \mathrm{Km}$, do Oceano Atlântico, que favorecem o efeito da continentalidade. As médias anuais de temperatura calculadas para o Pantanal e seus arredores estão entre 22,4 e $25,6^{\circ} \mathrm{C}$ (Tarifa, 1986). Segundo este autor, nas estações de menores latitudes, como Cuiabá e Cáceres, outubro é o mês mais quente, e dezembro o mais quente nas estações de maiores latitudes, como Corumbá, Aquidauana e Campo Grande, e julho o mês mais frio nessas 5 estações. Nestas três localidades, são registradas as menores temperaturas médias anuais, respectivamente $25,1^{\circ}, 23,9^{\circ}$ e $22,4^{\circ} \mathrm{C}$, provavelmente por estarem sujeitas à maior atuação dos sistemas extratropicais. 
Os índices de pluviosidade aumentam com o aumento da altitude. $\mathrm{Na}$ planície pantaneira, um centro de baixa pressão favorece as cheias periódicas, também condicionadas pelo relevo da área. Nesta planície, o período úmido é mais curto, de novembro a fevereiro, com cinco meses secos e uma pluviosidade média anual de 1000 mm (RadamBrasil, 1982a).

As enchentes não ocorrem de maneira homogênea na Bacia do Alto Paraguai, pois as precipitações são maiores nos extremos norte e sul, e nos planaltos, com índices médios que variam de 1100 a $1800 \mathrm{~mm}$ por ano, do que na porção centro-oeste, com índices médios de aproximadamente $800 \mathrm{~mm}$ por ano (Alvarenga et al., 1984; Salvi-Sakamoto, 2001). Por isto as enchentes ocorrem de março a abril ao norte da bacia, e de maio a agosto ao sul.

As médias pluviométricas anuais para o Pantanal estão entre 850 a 1100 $\mathrm{mm}$, inferiores, portanto, aos índices registrados nas áreas mais altas do entorno (Alvarenga et al., 1984). O Pantanal apresenta uma deficiência hídrica anual superior a $300 \mathrm{~mm}$, visto que a evapotranspiração potencial anual é superior a 1400 mm (Alfonsi e Camargo, 1986). Tarifa (1986) salienta que na planície as precipitações seguem um padrão de ilhas com distribuição espacialmente aleatória, por serem geradas por processos convectivos locais, resultantes do elevado aquecimento basal da coluna de ar.

A rede de drenagem do Pantanal é comandada pelo Rio Paraguai e seus afluentes. O rio Paraguai nasce na Chapada dos Parecis, percorre planaltos e serras, e finalmente passa a correr pela planície pantaneira até sua confluência com o rio Apa, que marca o limite sul do Pantanal e o da própria Bacia do Alto Paraguai. Desse trecho em diante, o Rio Paraguai flui até desembocar no rio Paraná, que deságua no Prata (Carvalho, 1986). 
Na margem direita do Rio Paraguai os rios permanentes mais importantes que atravessam o Pantanal são: o rio Sepotuba, Cabaçal e Jauru, e na margem esquerda, o Cuiabá, Taquari, Negro, Miranda e Apa. Destes, os rios Taquari e Negro são anastomosados, com inúmeros meandros abandonados, reabastecidos nos períodos de cheias. Na porção noroeste do Pantanal, as grandes lagoas perenes, como Uberaba e Gaiba, são de água doce, com dimensões que chegam até dezenas de $\mathrm{Km}^{2}$ no período de seca, e centenas de $\mathrm{Km}^{2}$ no período de cheia.

Em resumo, as principais unidades hidrográficas presentes na planície pantaneira são os rios, as grandes lagoas perenes, as lagoas salinas e as baias, permanentes a temporárias, os corixos e as vazantes. Em quase toda planície essas unidades são afetadas pela dinâmica das inundações, sendo que as vazantes somente nas cheias muito excepcionais.

Nota-se que a presença de centenas de lagoas, salinas e não salinas, as baías, é uma característica peculiar da porção sul e sudoeste da Nhecolândia. Nessa área também são frequentes as vazantes, ou cursos d’água intermitentes, das quais se destacam as principais, como a Vazante do Courixinho, Almoço, Capivari e a do Castelo (Carvalho, 1986 e Por, 1995).

\subsection{Solos e vegetação}

Na classificação dos solos do Pantanal pelo Projeto RadamBrasil (1982), escala 1:1.000.000, a planície é quase totalmente recoberta por diferentes classes de solos hidromórficos, que refletem inundações periódicas e prolongadas.

Na porção norte do Pantanal identificou-se as seguintes classes de solos: Laterita Hidromórfica, Planossolo, Solonetz Solodizado, Vertissolo, Podzólico 
Vermelho-Amarelo, Glei Pouco Húmico e Solos Aluviais. Já na parte central, formada por sedimentos arenosos transportados pelo Rio Taquari, o solo de maior ocorrência é o Podzol Hidromórfico, seguido do Planossolo, Areias Quartzosas Hidromórficas, Laterita Hidromórfica e Glei Pouco Húmico (Cunha, 1981). Na porção sul, formada por sedimentos argilosos depositados principalmente pelos rios Aquidauana, Negro e Paraguai, foram mapeados Planossolos, Vertissolos, Solonetz Solodizados, Gleis Pouco Húmicos e Lateritas Hidromórficas (RadamBrasil, 1982a).

Na Nhecolândia aparece apenas uma classe de solo, o Espodossolo, nova nomenclatura do Podzol Hidromórfico (Embrapa, 2006). Os processos pedológicos que acompanham a concentração das águas nessa área formam nódulos de calcita, Mg-silicatos, tipo stevensita e saponita, no horizonte superficial, e K-silicatos, tipo Fe-illita, que predominam na fração argila em alguns horizontes profundos na base dos perfis (Furquim, 2007; Furquim et al., 2008; Furquim et al., 2010b).

A cobertura vegetal associada aos diferentes tipos de solos no Pantanal é denominada de "Complexo Pantanal". Esta expressão abrange grande diversidade fisionômica, como campo inundável, vegetação aquática, capão, mata ciliar, cerrado, cerradão e floresta seca, cuja distribuição depende da topografia, das características dos solos, mas principalmente do regime de inundações (Pott e Pott, 2004). Em área, a província do cerrado é a que possui maior expressão e engloba grande parte da Nhecolândia (Adámoli, 1986).

Além do cerrado típico, algumas porções de terras apresentam vegetação mais densa, em outras se encontram vários tipos de palmeiras, adaptados aos solos pantaneiros com elevado teor de sal, como o buriti (Mauritia flexuosa) e o carandá (Copernicia australis), e mata ciliar ligada aos rios e corixos, rica em palmeira acuri 
(Attalea principes), pau-de-novato (Triplaris formicosa), ingazeiros (Inga), dentre outras (Por, 1997).

Nas interfaces entre ambientes aquáticos e terrestres do Pantanal as plantas flutuantes são abundantes, os principais produtores primários das águas, com grande variedade de macrófitas, tais como: a Victoria cruziana, os aguapés (Eichhornia cyanea, E. crassipes, Reussia subovata e $R$. rotundifolia), a alfaced'água (Pistia stratiotes), as espécies de "cruz-de-malta" (Ludwigia), a euforbiácea flutuante (Phyllanthus) e as pteridófitas flutuantes (Salvinia, Azolla, Ceratopteris). Estas formam uma cobertura densa denominada "batume", ou verdadeiras ilhas flutuantes chamadas "camalotes". Destaca-se também a Utricularia, pequena planta carnívora submersa que se alimenta de minúsculos crustáceos.

Nas lagoas podem estar presentes outras plantas superiores como o papiro (Cyperus giganteus), a taboa (Typha dominguensis) e a Sagittaria. Em solos permanentemente úmidos crescem, por exemplo, o hibisco (Hibiscus sp), a caeté (Thalia geniculata), o fumo-bravo (Polygonum hispidum). Durante o período de seca, o capim-mimoso (Paratheria, Setaria e Reimaria) forma uma rica pastagem nos solos aluvionais dos pântanos (Por, 1995).

Além dessas macro-espécies ligadas aos ambientes de interface, encontrase nas salinas gêneros de algas e cianobactérias. No inventário desses gêneros feito por Santos (2008) em três lagoas salinas na Nhecolândia (Fazenda Nhumirim) as classes mais representativas em termos de riqueza de táxons foram a Bacillariophyceae (23 táxons), Cyanobacteria (22 táxons), e a Euglenophyceae (21 táxons).

No experimento realizado em laboratório para avaliar os efeitos do $\mathrm{pH}$ da água no crescimento e morfologia de cianobactérias ( $A$. Elenkinii) dessas salinas 
verificou-se que entre $\mathrm{pH} 7.0$ a 9.5 não há diferença significativa em seu crescimento, mas sim uma variação morfológica ligada à relação larguracomprimento das células (Santos et al., 2011). No tratamento em pH 9.5 as células ficam mais curtas do que em $\mathrm{pH}$ 7.0. Os autores concluíram que as taxas de crescimento e rendimento das células são maiores em $\mathrm{pH} 10.5$, indicando que essa cianobactéria é típica de ambientes alcalinos. Por outro lado, valores de $\mathrm{pH}$ inferiores a esse podem limitar o crescimento em termos de densidade e biomassa. Em síntese, os autores comprovaram que a floração de cianobactérias é favorecida pelos valores elevados de $\mathrm{pH}$ encontrados nas águas das lagoas alcalinas da Nhecolândia.

Isto remete ao quadro químico dessa área dentro da Bacia do Alto Paraguai.

\subsection{A Nhecolândia no quadro hidroquímico da Bacia do Alto Paraguai}

As águas da Bacia do Alto Paraguai que abastecem o Pantanal são misturas de três pólos químicos espacialmente distribuídos em grandes áreas localizadas ao N, NE, E, SE, e S da bacia (Rezende Filho, 2011).

O $1^{\circ}$ pólo se caracteriza pelas águas pouco mineralizadas provenientes dos Planaltos a leste da Bacia que circulam, basicamente, sobre rochas areníticas. A composição química desse pólo é fortemente marcada por $\mathrm{SO}_{4}{ }^{2-}$ e $\mathrm{NH}_{4}{ }^{+}$, e a influência desses elementos aumentam na estação chuvosa. O $2^{\circ}$ pólo químico é composto pelas águas que circulam nos extremos nordeste e sudeste da Bacia, e pode ser dividido em dois conjuntos: um de águas com carga total muito baixa, e condutividade elétrica de $\sim 30 \mu \mathrm{S} . \mathrm{cm}^{-1}$, que circulam em áreas com arenitos; o outro, de águas com cargas mais elevadas, e condutividade elétrica entre 100 e 150 $\mu S . \mathrm{cm}^{-1}$, que circulam em áreas de rochas cristalinas. $\mathrm{O} 3^{\circ}$ pólo químico 
corresponde a águas mais carregadas, com condutividade elétrica entre 300 e 500 $\mu S . \mathrm{cm}^{-1}$, fortemente influenciadas por cálcio, magnésio e alcalinidade-carbonatada, provenientes de áreas com rochas calcárias localizadas ao norte e ao sul da Bacia. O autor estimou que a geologia regional explica aproximadamente $50 \%$ da variabilidade química total das águas, o uso e ocupação dos solos explicam cerca de $15 \%$, e as demais fontes de variabilidade não puderam ser identificadas.

No Pantanal, a área ocupada pela Nhecolândia é influenciada principalmente pelo Pólo 2, e secundariamente pelo Pólo 1 em alguns pontos de algumas nascentes do Rio Negro, onde o uso do solo é dado por atividades agrícolas instaladas no planalto (Rezende filho, 2011).

Efetivamente, em particular na baixa Nhecolândia, as águas superficiais, rios, vazantes, baías, salinas; e sub-superficiais, lençol freático, apresentam grande variabilidade química e extensa gama de condutividade elétrica. Porém, apesar da variabilidade, constatou-se que essas águas pertencem a uma mesma família geoquímica. A hipótese é que as águas superficiais mais mineralizadas, como as das salinas, com $\mathrm{pH}$ acima de 9 e maiores teores de $\mathrm{CO}_{3}{ }^{2-}$ e $\mathrm{Na}^{+}$, provêm da concentração das águas inicialmente diluídas, ou pouco mineralizadas, com pH inferior a 7 (Barbiéro et al., 2002). Para estes autores, na medida em que a água se evapora e vai se concentrando há conservação de alguns elementos e saturação em outros, e consequente aumento de $\mathrm{pH}$, ou seja, ocorre uma mudança no perfil químico das águas durante a evaporação.

A concentração das águas por evaporação explica mais de $76 \%$ da variabilidade química total das águas na escala regional da Nhecolândia. Contudo, nota-se localmente que o processo de concentração das águas não pode explicar o aumento dos teores em sulfato e cloreto, provavelmente relacionados: (i) à 
fertilização dos solos nos planaltos; (ii) aos processos redox locais; (iii) e a transformações pedológicas (Barbiéro et al., 2008, Rezende Filho, 2011).

A identificação de águas concentradas, com pH entre 8 e 10, nas salinas da Nhecolândia não é fato novo, nem recente. Outros trabalhos já haviam mencionado o teor alcalino das águas nas salinas, com altas concentrações de $\mathrm{HCO}_{3}^{-}, \mathrm{Cl}^{-}, \mathrm{Na}^{+}$e $\mathrm{K}^{+}$(Cunha, 1942, Brum e Souza, 1985).

Estudos realizados na Salina do Meio (Fazenda Nhumirím, Embrapa Pantanal) estabeleceram relações entre grau de salinidade e processos evaporatórios, mas também entre grau de salinidade e funcionamento hidrológico da salina, que é controlado por soleiras (Barbiéro et al., 2008). No decorrer deste trabalho estes aspectos serão retomados.

A presença de sais nas lagoas da Nhecolândia tem sido atribuída a um fenômeno antigo de acumulação de sais, uma herança de fases áridas ocorridas no Pleistoceno ou início do Holoceno (Braun, 1977 e Klammer, 1982), com consequente formação de dunas por deflação eólica (Tricart, 1982), ou de evaporitos (Braun, 1977).

Deste modo, mesmo a presença de cones aluviais no Pantanal, como o do Taquari, é usada para demonstrar que essa sedimentação, em grande parte de forma torrencial, é decorrente de um período de intensa erosão, ligado a condições climáticas mais áridas no final do Pleistoceno e início do Holoceno (Braun, 1977). Esse argumento pode ser refutado pelos estudos de geomorfologia fluvial realizados recentemente no Leque do Taquari, que mostram que ainda hoje ele é ativo, em formação pelos frequentes processos de avulsão, típicos desses ambientes (Assine, 
2003), favorecidos pela própria subsidência, ainda ativa, do arcabouço estrutural do Pantanal (Shiraiwa, 1994; Ussami, 1999; Assine, 2003).

Em resumo, a origem da salinidade ainda não foi totalmente esclarecida, apesar de hoje se saber que o processo de evaporação responde por mais de $76 \%$ da variabilidade química total das águas da Nhecolândia. Por outro lado, e independentemente da origem da salinidade, ainda pouco se conhece sobre o funcionamento atual dessas salinas.

\section{REVISÃO BIBLIOGRÁFICA}

Os lagos e lagoas são tidos como corpos de águas estacionárias, e considerados como fenômenos de curta duração na escala geológica (Esteves, 1988; Tundisi e Tundisi, 2008).

Nota-se uma diferenciação entre lagos e lagoas. Os primeiros são definidos como corpos de água profundos, e por isto apresentam estratificações térmicas com diferentes teores de oxigênio dissolvido, que delimitam diferentes camadas tropogênicas. Ao contrário, as lagoas são corpos de água de conformação geralmente rasa, sem estratificações, e por isso com grande camada tropogênica em relação ao seu volume total (Kleerekoper, 1944).

Em função dessas definições percebe-se que o sistema lacustre da Nhecolândia é composto principalmente por lagoas. Dentre tais lagoas, uma minoria é salina. Define-se lagos salinos aqueles onde o total de sólidos dissolvidos (TDS) na água excede 3 g/L (Williams, 1964 e Hammer, 1986 apud Meybeck, 1995). Sabendo-se que $1 \mathrm{~g}$ TDS é igual a $1 \mathrm{mmho} . \mathrm{cm}^{-1}$, que equivale a uma condutividade 
elétrica de $1 \mathrm{mS} . \mathrm{cm}^{-1}$, então $3 \mathrm{~g}$ TDS/L é igual a uma condutividade elétrica da água de $3000 \mu$ S. $\mathrm{cm}^{-1}$ (Melack, 1988).

De um modo geral, os lagos salinos ocorrem em áreas onde as taxas de evaporação excedem as de entrada externa de águas, ou onde há dissolução de depósitos salinos pré-existentes, ou de solos salinos formados em regiões áridas, ou ainda, em áreas onde ocorre aporte regular de sal pelo oceano (Meybeck, 1995). Este autor mostra que não existe lagos salinos, sobretudo os de grandes dimensões, fora das zonas costeiras ou das bacias endorréicas. Geralmente, os lagos salinizados em decorrência dos processos de evaporação excederem inputs externos de águas aparecem somente em posições terminais dos sistemas de drenagens endorréicas. O autor conclui que, salvo raras exceções, todos lagos situados em posições terminais na drenagem endorréica são salinos.

Isto coloca alguns problemas em relação às lagoas salinas do sistema lacustre da Nhecolândia: $\left(1^{\circ}\right)$ as condições climáticas atuais não são, a priori, favoráveis nem à acumulação, nem à manutenção de sais solúveis na paisagem; $\left(2^{\circ}\right)$ se a salinidade é um indicador de mudanças climáticas do passado, em particular, da presença de climas áridos no Pleistoceno ou início do Holoceno, então como explicar que as salinas constituem a minoria das lagoas que compõem o sistema lacustre da Nhecolândia (?).

Estas questões permearam a busca de um apoio teórico na literatura, a fim de verificar se existem sistemas lacustres semelhantes ao da Nhecolândia em outros continentes, principalmente quanto à morfologia das lagoas e das condições físicoquímicas das águas. 


\subsection{Regiões de lagos no mundo}

Os sistemas lacustres com lagoas salinas são comuns em áreas de climas mais secos, por exemplo, na China no Deserto de Badain Jaran, no sudoeste da Austrália, no centro-sul e leste-nordeste da África, no Vale do Rio Zimbaze, e no Grande Rift Africano, respectivamente.

Em Badain Jaran ocorrem inúmeras lagoas nas depressões interdunas, ligadas ao afloramento do lençol freático regional instalado sobre um assoalho de baixa permeabilidade (Figura 5). Esse lençol circula em um material que alterna camadas muito permeáveis eólico-arenosas com depósitos sedimentares pouco permeáveis de paleo-lagos, responsáveis por seu afloramento (Yang e Williams, 2003, Gates et al., 2008). A forma dessas lagoas é irregular, ligeiramente arredondada ou alongada. Nesse ambiente tipicamente árido, as águas são submetidas a fortes processos de evaporação, que levam a uma salinidade alcalina. Estudos geoquímicos mostram que a evaporação da água é acompanhada de forte elevação do $\mathrm{pH}$, e de um controle do cálcio e do magnésio em solução, fazendo a água evoluir numa via alcalina--sódica (Valles et al., 1991).

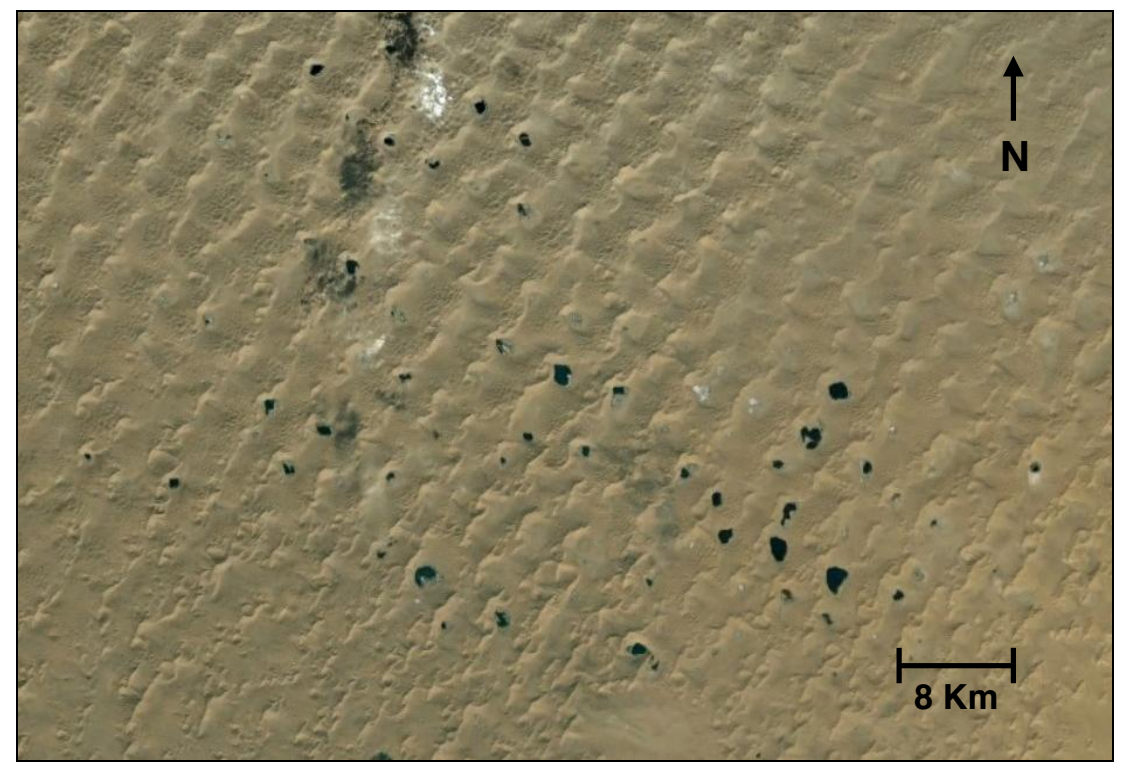

Figura 5. Deserto Badain Jaran (China): afloramento do lençol freático em superfície e lagoas alcalinas nas depressões interdunas (Gates et al., 2008). 
No sudoeste da Austrália as inúmeras lagoas alinhadas nas terras baixas são pouco profundas, com forma assimétrica de "lunettes". Essa forma é ligada à deflação eólica, e acumulação de partículas finas nas bordas das depressões, segundo a direção do vento dominante, que determina a assimetria da forma (Figura 6). Na estação seca, as águas se evaporam nas depressões, e favorecem a cristalização rápida de sais como gipso $\left(\mathrm{CaSO}_{4}, 2 \mathrm{H}_{2} \mathrm{O}\right)$ e halita $(\mathrm{NaCl})$, facilmente remobilizados pelo vento (Tricart, 1954; Michel, 1973; Mougenot, 1982; Mohamedou et al., 1999, Furian et al., 2011). O contexto geoquímico da água nesses ambientes é salino neutro, e geralmente tende a evoluir para salino sulfatado (Valles et al., 1991).

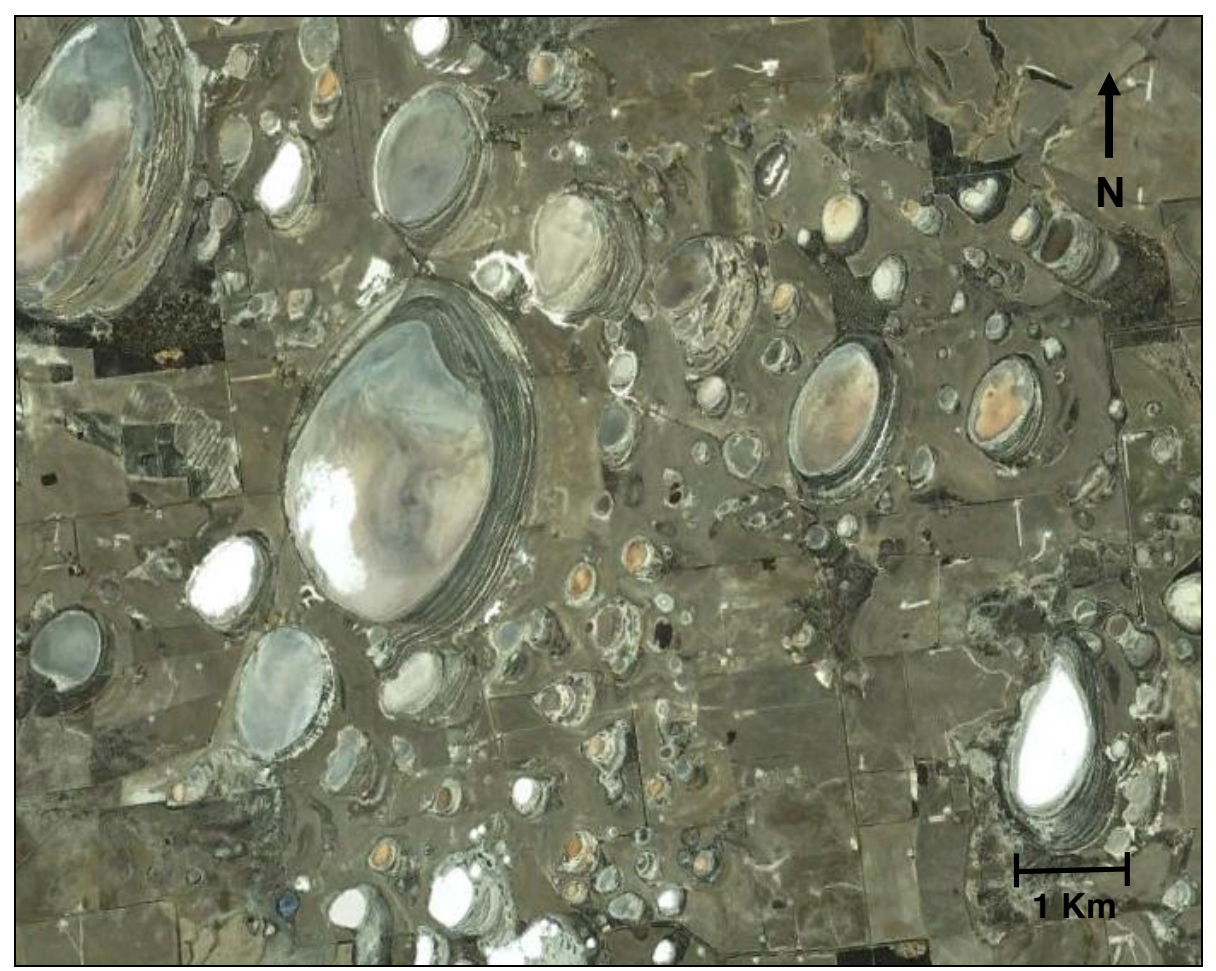

Figura 6. Visão oblíqua das lagoas do Sudoeste da Austrália. Nota-se a forte salinidade que se cristaliza em eflorescências brancas durante a estação seca (Imagem Google Earth, 2011).

Lagoas com assimetria semelhante a das lagoas do SW da Austrália aparecem no Vale do Zambeze (Zâmbia), porém com assimetria inversa, pois resultantes de ventos alísios de SE (Figura 7). A acumulação de partículas em forma 
de lunettes ocorre nas porções W-NW das lagoas, cujas localizações na paisagem não são aleatórias, mas orientadas em posições interdunas do grande Erg do Kalahari. Provavelmente esses lagos se formaram em ambiente salino neutro, mas atualmente estão sendo destruídos pela dissecação do platô situado à montante.

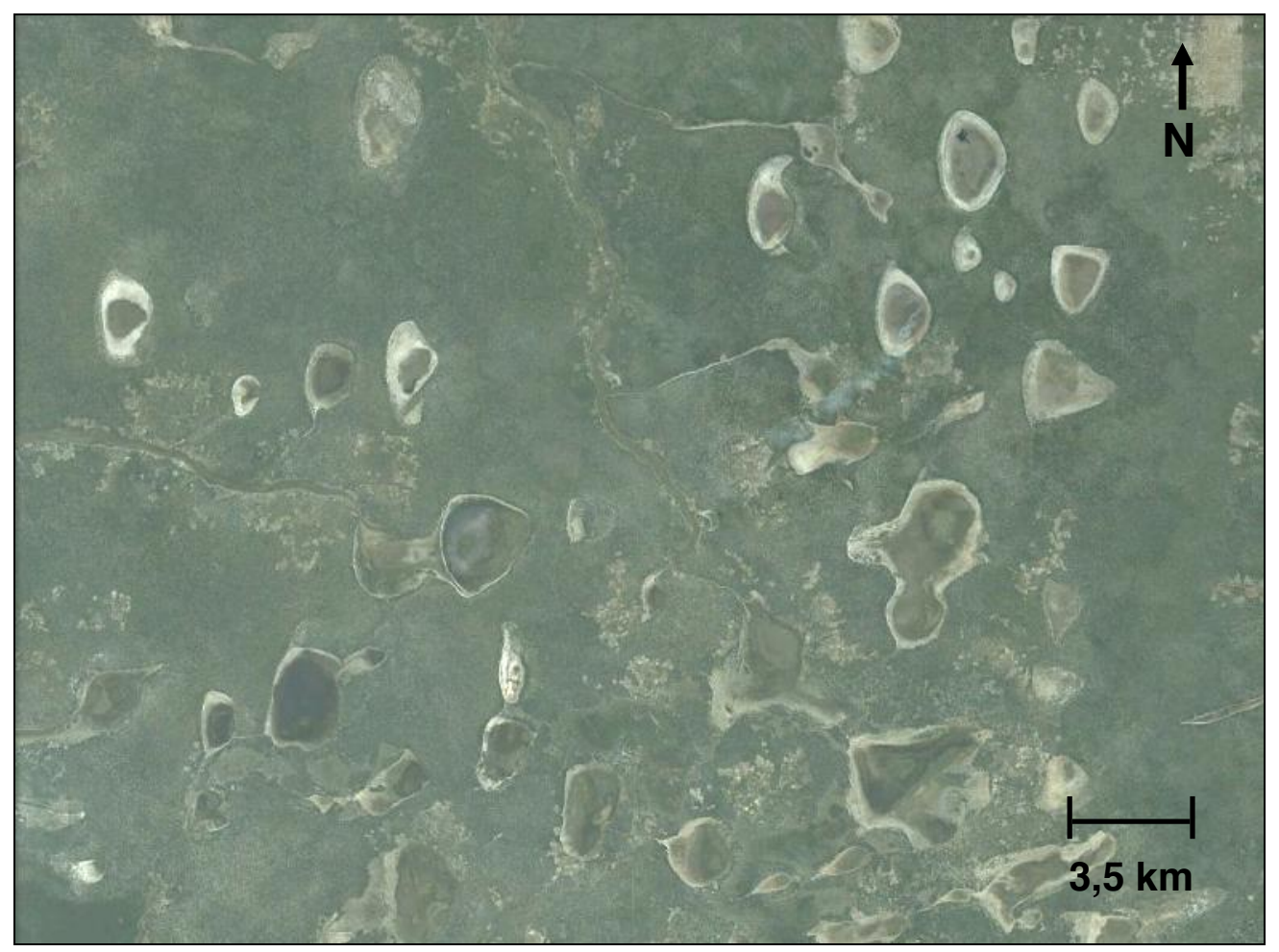

Figura 7. Terraço do Vale Zambeze (Zâmbia) com lagoas em forma de "lunettes" (Imagem Google Earth, 2011).

A maior parte dos lagos salinos-alcalinos do Rift Africano integram sistemas fechados de drenagem situados em altiplanos, alguns com altitudes superiores a $2500 \mathrm{~m}$. A salinidade resulta tanto de processos atuais, ligados a altas taxas de evaporação, ventos fortes, e atividades tectônicas recentes, sobretudo vulcânicas, quanto de processos passados, ligados à influência marinha e presença de evaporitos. Estima-se que apenas na Etiópia existam $7000 \mathrm{~km}^{2}$ de corpos de águas interiores, a maior parte ligada a sistemas fechados de drenagem, cuja profundidade varia em função do relevo, desde os lagos rasos com 0,21 a $3 \mathrm{~m}$, até os profundos com 37 e 245 m (Wood e Talling, 1988; Tudorancea e Harrison, 1988). Nos lagos 
rasos alcalinos, com mais de $20 \mathrm{~km}^{2}$, a taxa de salinidade pode aumentar mais de $5 \mathrm{~g} / \mathrm{L}$ por mês, e são inseridos dentre os mais produtivos ecossistemas em termos de biomassa e produção primária (Melack, 1988).

Os lagos arredondados que caracterizam a Flórida Central (EUA) são relativamente mais profundos que os citados anteriormente (Figura 8). Os lagos deste sistema lacustre não estão associados à salinidade, mas à dissolução química de rochas calcárias, em um ambiente que não é evaporatório, contrariamente aos exemplos acima citados, (Schiffer, 1998).

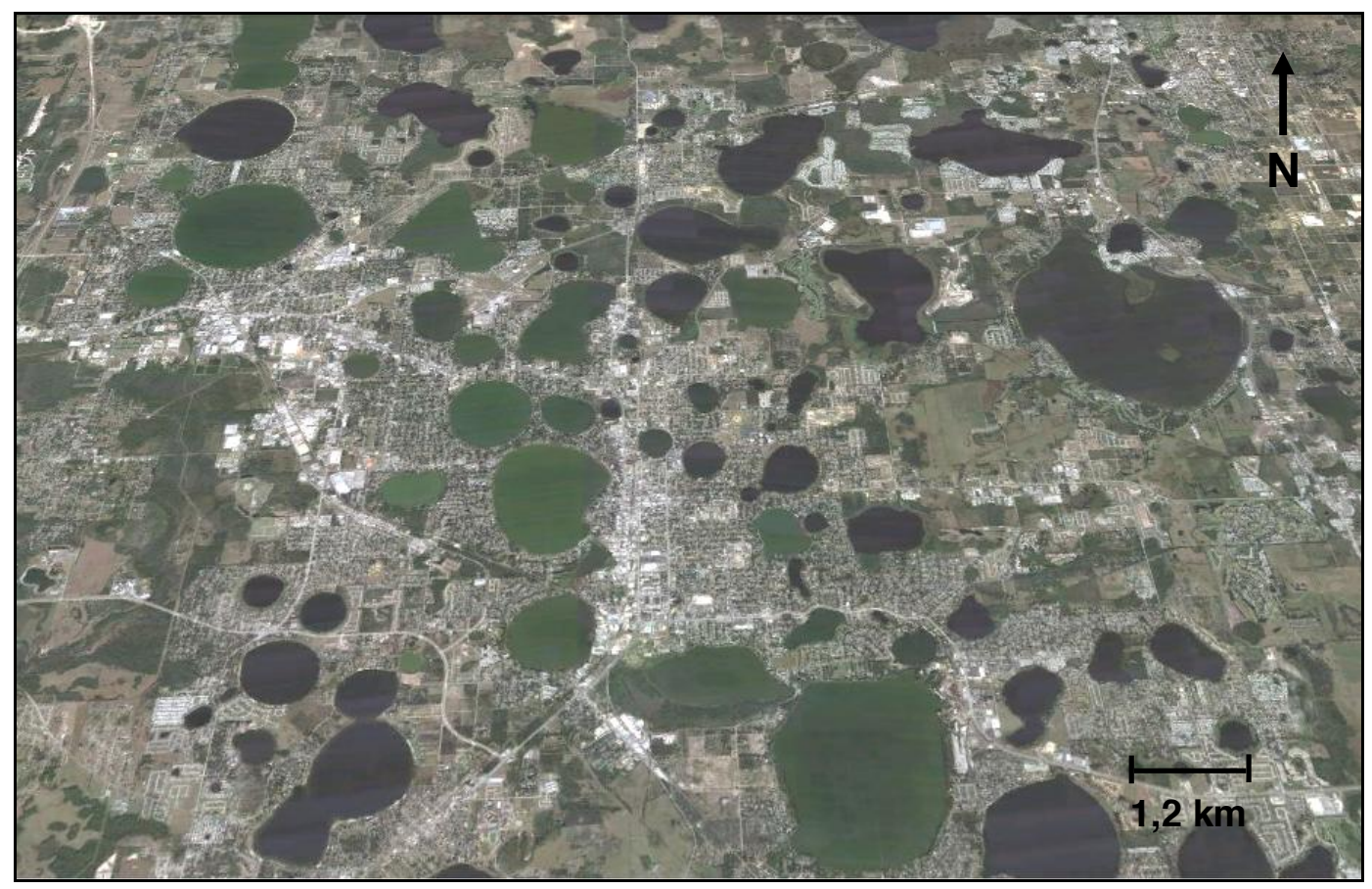

Figura 8. Lagos cársticos na Flórida Central (Imagem Google Earth, 2011).

\subsection{Sistemas Lacustres no Brasil}

Anteriormente mencionou-se que os sistemas ou ambientes lacustres são muito comuns no Brasil, grande parte deles em planícies costeiras, e o restante no interior do continente em planícies fluviais. Na zona costeira, esses sistemas têm sido geralmente ligados a processos fluvio-marinhos (Silveira, 1998; Ab'Saber, 2006). No interior do continente, a maior parte desses sistemas está ligada a 
processos fluviais atuais, e pretéritos, estes decorrentes de flutuações do nível do mar no Pleistoceno (Irion et al., 1997; Costa et al., 2007).

Estima-se que na Amazônia Central o médio e baixo curso do Rio Amazonas, e seus principais tributários, são acompanhados por uma várzea de aproximadamente $300.000 \mathrm{~km}^{2}$ (Iron et al., 1997), que comporta um complexo sistema lacustre, cujas formas têm origem fluvial (Melack, 1984 apud ; Irion et al., 1997; Tundisi et al., 1999; França, 2007). Apenas a calha do Rio Amazonas, com $62.000 \mathrm{Km}^{2}$ de várzea, apresenta 6.510 lagos (Sieppel et al., 1992 apud França, 2007), que somados aos dos principais tributários totalizam 8.050 (Melack, 1984 apud França, 2007).

A área lacustre do Médio Rio Doce, em Minas Gerais, compreende mais de 100 lagos com dimensões desiguais, que variam de alguns metros quadrados a mais de $5 \mathrm{~km}^{2}$, a maioria com forma dendrítica, com profundidade que entre 4 e 39 m, e comprimentos que podem ultrapassar 5 km (Mousinho de Meis e Tundisi, 1986; Melo et al., 1999; Bezerra-Neto e Pinto Coelho, 2008).

Na Bacia do Alto Paraguai, na borda oeste do Pantanal, existem várias áreas de lagos adjacentes ao Rio Paraguai no limite com a Bolívia, e também ao sul junto ao Maciço do Urucum, em áreas com controle estrutural NE e NW (Urban et al., 1992 e Bezerra, 1999 apud Assine 2003). Além desses, destaca-se a Nhecolândia é conhecida pela presença de um amplo sistema lacustre, que será particularmente discutido no decorrer deste trabalho.

\subsubsection{Sistema Lacustre da Nhecolândia}

O sistema lacustre da Nhecolândia, localizado ao sul do Leque Aluvial do Taquari, apresenta milhares de lagoas, das quais muitas com água doce, as baías, e 
outras com água alcalina, as salinas, a coexistir a curta distância umas das outras. Esse sistema, cuja porção sul está instalada no lobo mais antigo do leque, é justaposto, e sobreposto, a um complexo sistema de drenagem. Percebe-se que mesmo do ponto de vista da forma, ele difere muito dos sistemas lacustres apresentados acima, embora sejam frequentes as formas arredondadas e alongadas em praticamente todos eles (Figura 9).

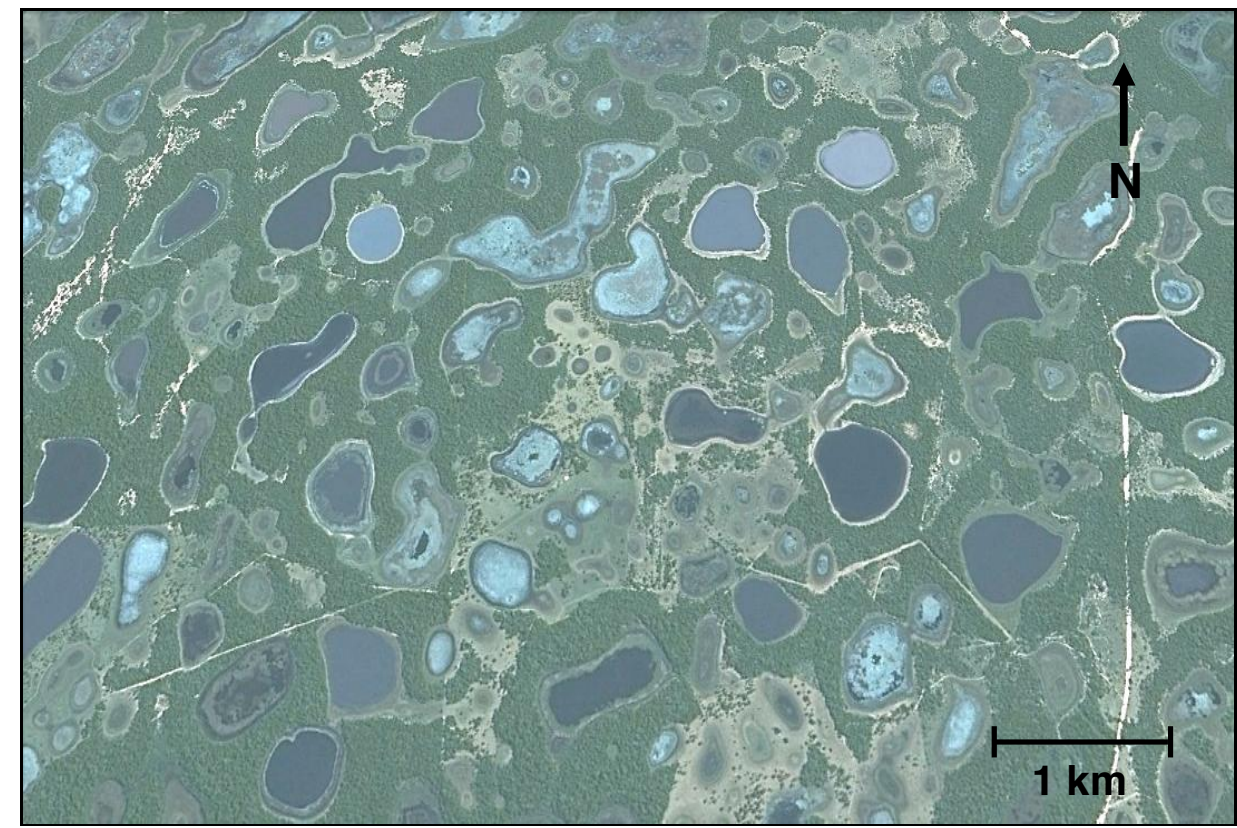

Figura 9. Lagoas no Pantanal da Nhecolândia (MS), Fonte: Imagem Google Earth/2010.

A origem das lagoas da Nhecolândia ainda é um tema de debate na comunidade científica, do qual se faz um pequeno lembrete. A hipótese proposta por Wilhelmy (1958), recentemente retomada por Ab'Sáber (2006), é que essas lagoas são formadas pelos deslocamentos de rios com padrão meândrico, regionalmente responsáveis por lagos de lóbulos internos de meandros, e lagos barrados por diques marginais, e lagoas em ferradura (oxbow lakes). Se a origem fluvial das lagoas pode ser confirmada em algumas partes do Pantanal, principalmente ao longo dos rios principais, com destaque ao Rio Paraguai onde essa hipótese se 
aplica com pertinência, nenhuma observação, sobretudo morfológica, permite transpor esse modelo de formação para as lagoas da Nhecolândia.

Outra hipótese recorre à deflação eólica num contexto antigo de salinidade decorrente de climas mais secos do Pleistoceno e Holoceno (Almeida e Lima, 1956), seguida de acumulação de partículas, especialmente da fração areia, sob a forma de dunas do tipo "Sebkha" e "Lunettes" (Tricart, 1982). O tamanho das partículas de areia nas cordilheiras da Nhecolândia foi usado como argumento na direção dessa hipótese (Almeida, 1945). Klammer (1982) reconhece sua parcialidade, pois nem todas as áreas com paleodunas, acumulações de areia em forma de cordões que passaram a ser assimiladas às cordilheiras, apresentam lagoas. Soares et al., (2003), e Assine e Soares (2004) mostram que essas partículas de areia, bem selecionadas, podem ter sido herdadas dos arenitos dos planaltos que circundam o Pantanal, as áreas fontes desses sedimentos. Além disto, até agora nenhuma estrutura de depósito de paleodunas foi descrita ou observada no Pantanal, sobretudo na Nhecolândia (Colinvaux et al., 2000).

Nota-se, pelos exemplos apresentados acima, que vários argumentos permitem descartar a hipótese de formação eólica dessas lagoas: $1^{\circ}$ ) ausência de uma assimetria típica nas lagoas e nas dunas associadas, que diferem claramente da morfologia das "Lunettes" (Figuras 5, 6 e 7); $2^{\circ}$ ); ausência de estratificação de "Iunettes" nas elevações que circundam as lagoas (Figuras 6 e 7); $3^{\circ}$ ) ausência de salinidade na maior parte das lagoas (Figura 7 ); $4^{\circ}$ ) ausência do quadro geoquímico alcalino-sódico, que impossibilita a cristalização de gipso e halita, sais que são geralmente responsáveis pela fragmentação em pó da estrutura dos horizontes superficiais das depressões (Figuras 6 e 7).

A partir de outra abordagem, Braun (1977) e Eiten (1983) atribuíram a gênese dessas lagoas a processos cársticos ou pseudo-cársticos (Figura 8). 
Contudo, não se encontram formações calcárias na Nhecolândia que poderiam traçar a evolução da paisagem por esses processos, salvo se os autores tivessem estabelecido relações entre dissolução do quartzo e pseudo-carste.

No sistema lacustre da Nhecolândia, apenas as lagoas salinas apresentam características geoquímicas similares às das lagoas do deserto de Badam Jarain na China. Do mesmo modo, do ponto de vista do comportamento limnológico, é muito provável que algumas salinas da Nhecolândia sejam similares aos lagos rasos alcalinos do Rift Africano descritos por Melack (1988). Contudo, o conjunto das lagoas não apresenta nenhuma similaridade morfológica com o das demais lagoas acima apresentados, embora a forma arredondada e alongada possa ser comum em todos os sistemas lacustres.

Para finalizar esta revisão bibliográfica, buscou-se verificar se os principais leques aluviais do mundo apresentam características similares às da Baixa Nhecolândia, na porção sul do Leque do Taquari.

\subsection{Sistemas lacustres e leques aluviais}

O objetivo deste tópico é verificar se existem sistemas lacustres desenvolvidos em outros leques aluviais distribuídos pelos continentes. De um modo geral, os leques aluviais são associados a regiões desérticas, pois a maioria dos modelos conhecidos provém dessas regiões, embora eles possam ocorrer sob todos os climas.

O Leque do Taquari se distingue por sucessões de lobos, antigos e recentes, que se superpõem, e por rios meandrantes, como o Taquari e o Negro, considerados de baixa sinuosidade em relação ao nível de base do Rio Paraguai. A morfologia do leque é marcada por traços de canais abandonados, que são 
parcialmente ativos durante as cheias. O processo de sedimentação se deu por ciclos de construção e abandono de lobos deposicionais arenosos durante o Quaternário (Assine, 2003). Este autor identificou 7 lobos no Leque do Taquari, sendo que os mais antigos 7, 6 se localizam na porção sul da Nhecolândia, e o 5 e 4, parcialmente (Figura 10). A presença de centenas de lagoas nessa porção sul do Leque apresenta uma morfologia completamente diferente da dos lobos de sua porção norte (Cunha, 1943, Brum e Souza, 1985, Mourão et al., 1988).

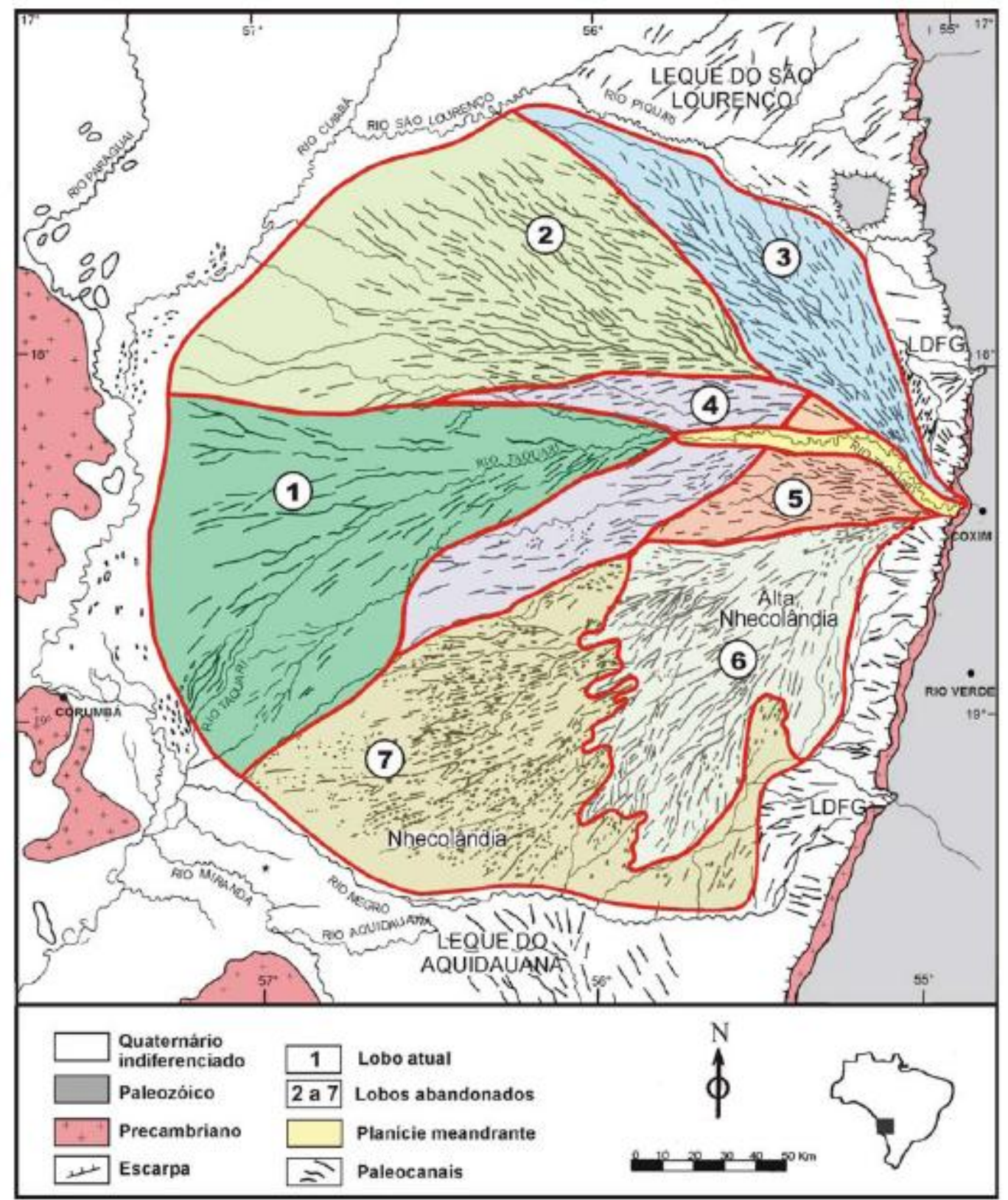

Figura 10. Subdivisão morfológica do Leque do Taquari em 7 lobos baseado nas características geométricas dos paleocanais (Assine, 2003). 
O leque do Rio Kosi (> $10.000 \mathrm{~km}^{2}$ ), situado no estado do Bihar no nordeste da Índia (Figura 11), tem o regime hidrológico influenciado pelas chuvas de monções, de regime torrencial. Embora as águas das precipitações sejam canalizadas a uma única saída, controlada há uns 50 anos, o rio Kosi transborda a cada ano (Sinha et al., 2008). A sedimentação do leque é episódica, por inundações fora do leito principal. As mudanças no regime deposicional ocorrem devido à alteração de canais que, por sua vez, afetam a planície, com taxas muito altas de sedimentação recente (Sinha e Friend, 1999).

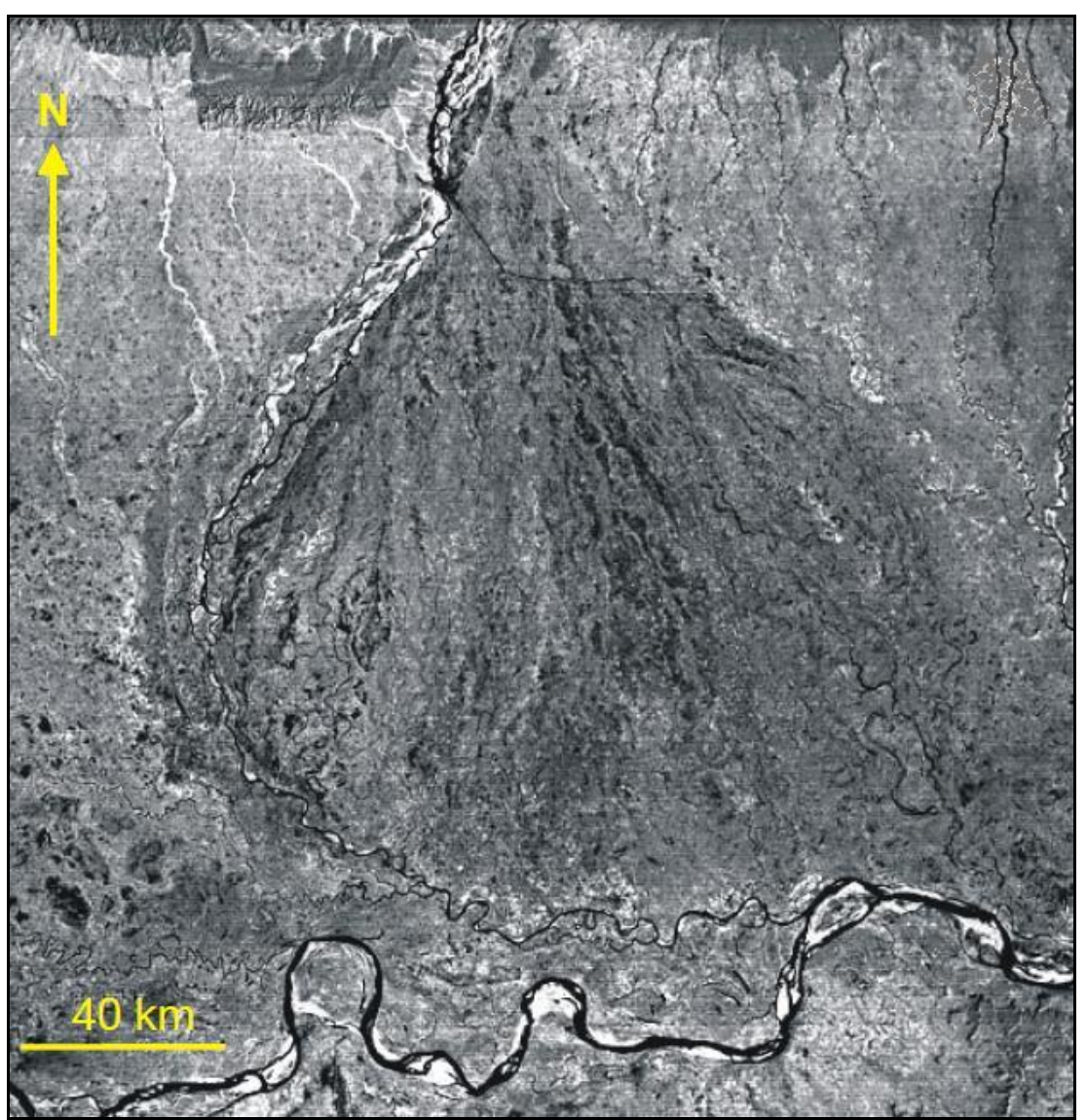

Figura 11. Leque do rio Kosi, Índia. (Fonte: Imagem Landsat, fevereiro de 1977, NASA, Assine, 2004).

Com base em documentos antigos, alguns autores têm proposto um esquema de migração lateral do Rio Kosi, de $113 \mathrm{~km}$ para oeste em apenas dois séculos (Assine, 2005). No entanto, um trabalho mais recente invalidou esses resultados e colocou o funcionamento sedimentológico do leque do Rio Kosi em 
proporções semelhantes a muitos outros leques aluviais no mundo (Chakraborty et al., 2010). As inúmeras lagoas que aparecem nesse leque são de meandros abandonados, e lagos rasos (Gohain e Parkash, 1990), além das lagoas de origem antrópica, feitas pela escavação de parcelas com formas retangulares, para armazenamento de água de uso agrícola (Figura 12).
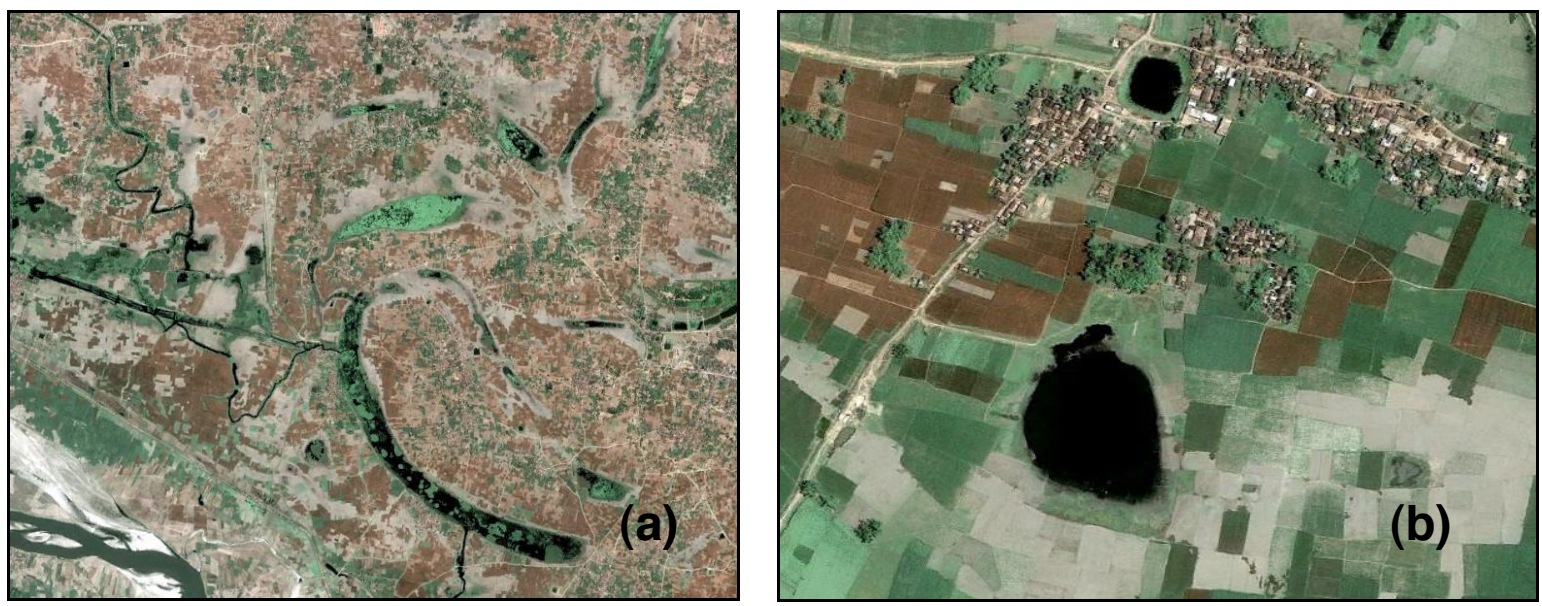

Figura 12. Lagos no leque do Kosi: (a) de meandros abandonados, e (b) na parte inferior da imagem lagos rasos, e na superior, lagos retangulares de origem antrópica, Índia (Imagens Google Earth, 2011).

O número de lagoas no Leque do Kosi é significativamente menor do que no Leque do Taquari. Além disto, dado o regime torrencial típico das chuvas que afetam o Leque do Kosi, em ambiente com amplitudes topográficas maiores que no Leque do Taquari, há no Kosi uma sedimentação mais marcada topograficamente, com entalhes de canais mais definidos, e marcas mais nítidas de meandros abandonados (Gohain e Parkash, 1990).

O leque aluvial do Okavango, mais conhecido como o Delta do Okavango, embora não seja, estritamente falando-se, um delta, desenvolve-se em clima semiárido no norte da Botsuana (Figura 13). Ele é alimentado pelas precipitações da Bacia do Alto Rio Okavango, localizada na Angola Central mais ao norte, em uma área de clima tropical úmido com estações contrastadas. A depressão onde o leque 
se formou corresponde à parte final do grande Rift Africano. A dimensão do leque varia de 12.000 a $18.000 \mathrm{~km}^{2}$, com centenas de canais abandonados, aproximadamente $98 \%$ da água desaparece na planície por evaporação e infiltração (McCarthy et al., 1991).

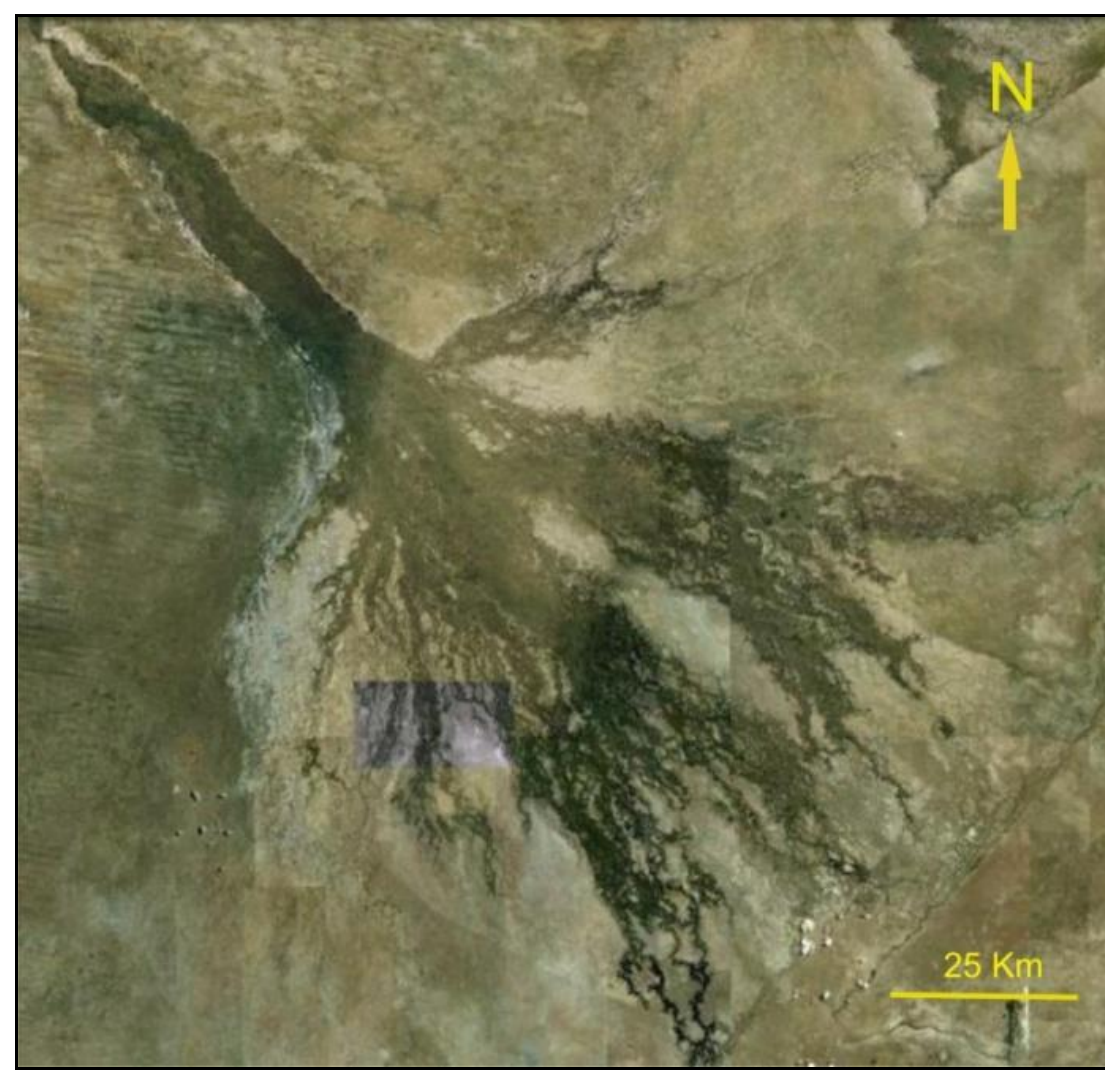

Figura 13. Leque aluvial do Rio Okavango - Botsuana (Imagem Google Earth, 2011).

As águas do lençol freático profundo deste Delta são salinas e alcalinas. Apesar das taxas elevadas de evapotranspiração anual ( 2400 mm), as águas superficiais não são fortemente mineralizadas, exceto nas denominadas "ilhas", uma unidade morfológica característica da paisagem do leque (Foto 1).

Essas ilhas são pequenas elevações de 2 a 3 m de altura e cerca de $200 \mathrm{~m}$ de largura, com uma depressão central ocupada por uma "lagoa" de 50 a 100 m de largura, com águas salinas-alcalinas. Nessas águas há um controle do cálcio e do magnésio em solução (McCarthy e Metcalfe, 1990 e McCarthy et al., 1991). Esses 
processos são comuns na evolução da água em via alcalina-sódica, segundo classificação de Valles et al., (1991). McCarthy et al. (1991) atribuem o controle do potássio à neoformação de K-silicatos.
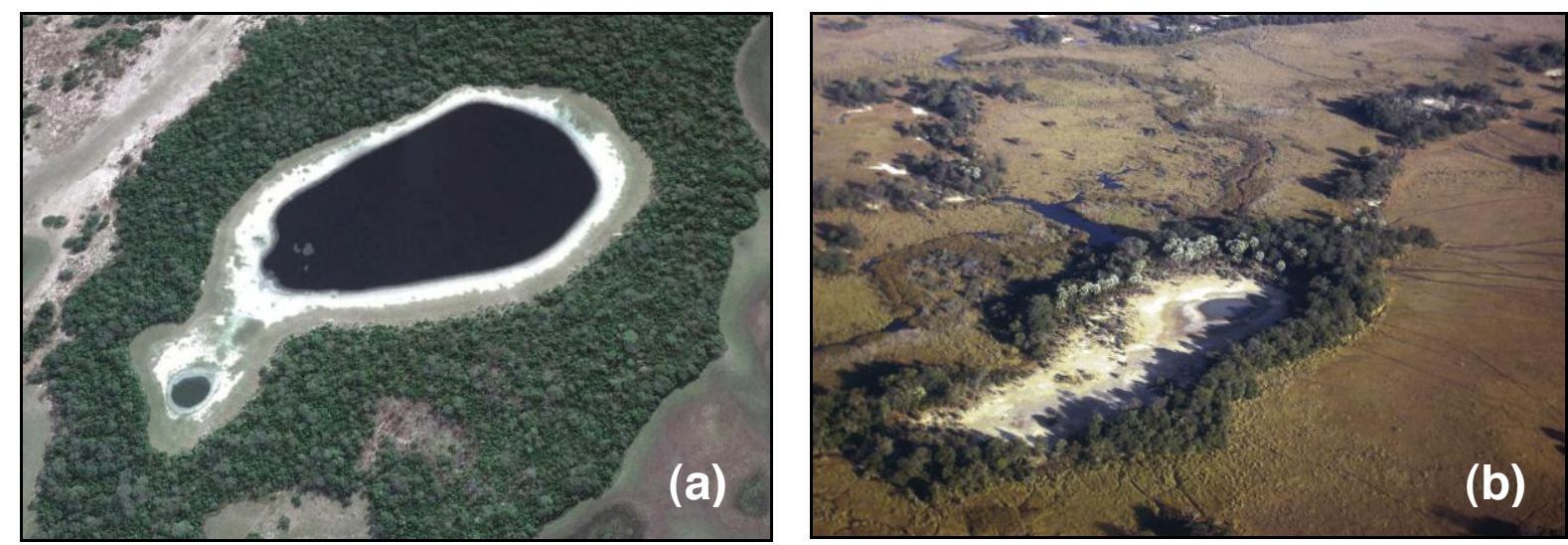

Foto 1. (a) Lagoa na Nhecolândia; (b) "Ilha" com lagoa no centro do Delta do Okavango (Bauer et al., 2006).

Segundo o modelo de funcionamento proposto, mas ainda não confirmado, as "ilhas" alimentam o lençol profundo com águas salinas, pelo processo de "fingering" decorrente da maior densidade das águas salinas (Bauer et al., 2006 a e b, 2007). Portanto, essas "ilhas" parecem ter um papel fundamental na concentração e eliminação das águas salinas, e permitem manter um ambiente superficial sem grande extensão da salinidade, que faz a riqueza do ecossistema do Delta (Ramberg e Wolski, 2008).

\section{CONSIDERAÇÕES GERAIS}

Primeiramente, a abordagem teórica realizada neste primeiro Capítulo coloca em evidência a peculiaridade do sistema lacustre da Nhecolândia, que é único, apesar de algumas semelhanças com o do Delta do Okavango. As semelhanças são de ordem geomorfológica, com dois ambientes de áreas úmidas, continental e intracontinental, desenvolvidos em leques aluviais formados por 
sedimentos de origem eólica, de um lado, por arenitos mal consolidados do Erg Kalahari, e de outro, por arenitos da Formação Botucatu.

Em termos morfológicos as lagoas da Nhecolândia apresentam certa similaridade com as lagoas existentes no centro das "ilhas" do Delta do Okavango (Foto 1). Observa-se que no entorno das lagoas do Okavango se desenvolve uma vegetação com palmeira (Hiphaene Petersiana), muito similar à palmeira Carandá (Copermicia Alba, Morong, 1893), que aparece no entorno das lagoas salinas na Nhecolândia. Além disto, em ambos os casos, a composição química da água se situa numa via alcalina sódica. Assim como as pesquisas feitas no Delta do Okavango destacam um controle do potássio pela neoformação de silicatos de potássio, na Nhecolândia também se ressalta que a neoformação de alguns tipos de argila (Mg-silicatos) e ilita (K-silicato) controlam o magnésio e o potássio nas lagoas salinas (Furquim, 2007).

Em síntese, as principais diferenças entre as lagoas do sul do Leque do Taquari e as do Delta do Okavango referem-se às dimensões das lagoas e às condições climáticas de evaporação e precipitação. As lagoas da Nhecolândia são muito maiores do que as do Okavango, mas os índices de evaporação no Okavango são muito superiores aos registrados na Nhecolândia.

Assim como a origem do sistema lacustre da Nhecolândia não se encontra ainda bem esclarecida, principalmente a questão da salinidade de algumas lagoas dentro dele, também pouco se conhece sobre o funcionamento atual dessas salinas e, principalmente, quais são os processos responsáveis pela elevada gama de salinidade que apresentam. Essas questões nortearam os objetivos do presente trabalho. 


\section{OBJETIVOS}

O principal objetivo deste trabalho é estabelecer uma tipologia de lagoas salinas da Nhecolândia baseada em seus funcionamentos: hidrológico, geoquímico e/ou biogeoquímico. Em decorrência deste, os objetivos específicos são:

a) Identificar os fatores de variabilidade das salinas por meio de estudos regional e local, de variáveis como o pH, condutividade elétrica (CE), condições redox, oxigênio dissolvido;

b) Entender as relações de dependência que existem entre tais variáveis;

c) Identificar os processos, responsáveis e decorrentes, de variabilidade: hidrológicos, pedológicos, geoquímicos ou biogeoquímicos;

d) Compreender a distribuição espacial da variabilidade química no ambiente. 
CAPÍTULO II

AS ÁGUAS NA NHECOLÂNDIA 
Um dos principais pontos a destacar do capítulo anterior é a grande variabilidade química das águas de superfície na Nhecolândia. Se os processos responsáveis por essa variabilidade são, hoje, relativamente bem conhecidos, a distribuição espacial da variabilidade ainda é pouco conhecida. Principalmente, se a variabilidade apresenta, ou não, algum padrão espacial de organização regional. Este é o objetivo deste capítulo.

Para isto realizou-se duas etapas de trabalho. A primeira, feita a partir de análises multivariadas das características físico-químicas das águas, teve como objetivo: (a) identificar e hierarquizar os eixos de variabilidade, (b) determinar qual é a variável, ou combinação linear de variáveis, associada aos eixos de variabilidade.

A segunda etapa, realizada por meio de um tratamento geoestatístico, foi dedicada ao estudo da distribuição espacial da variável, ou combinação linear de variáveis, identificada na primeira etapa.

Este trabalho foi realizado na porção sul do Leque do Taquari, na Baixa Nhecolândia (Figura 14).

\section{MATERIAIS E MÉTODOS}

\section{1. Área de estudo e aquisição de dados}

Utilizou-se um conjunto de 3 amostragens de águas superficiais da Nhecolândia, num total de 307 amostras.

Amostragem I: A primeira amostragem foi feita no decorrer desta pesquisa, e totaliza 73 amostras georeferenciadas, coletadas na porção sul da Nhecolândia ao norte de Aquidauana em 2010 (Figura 14). 


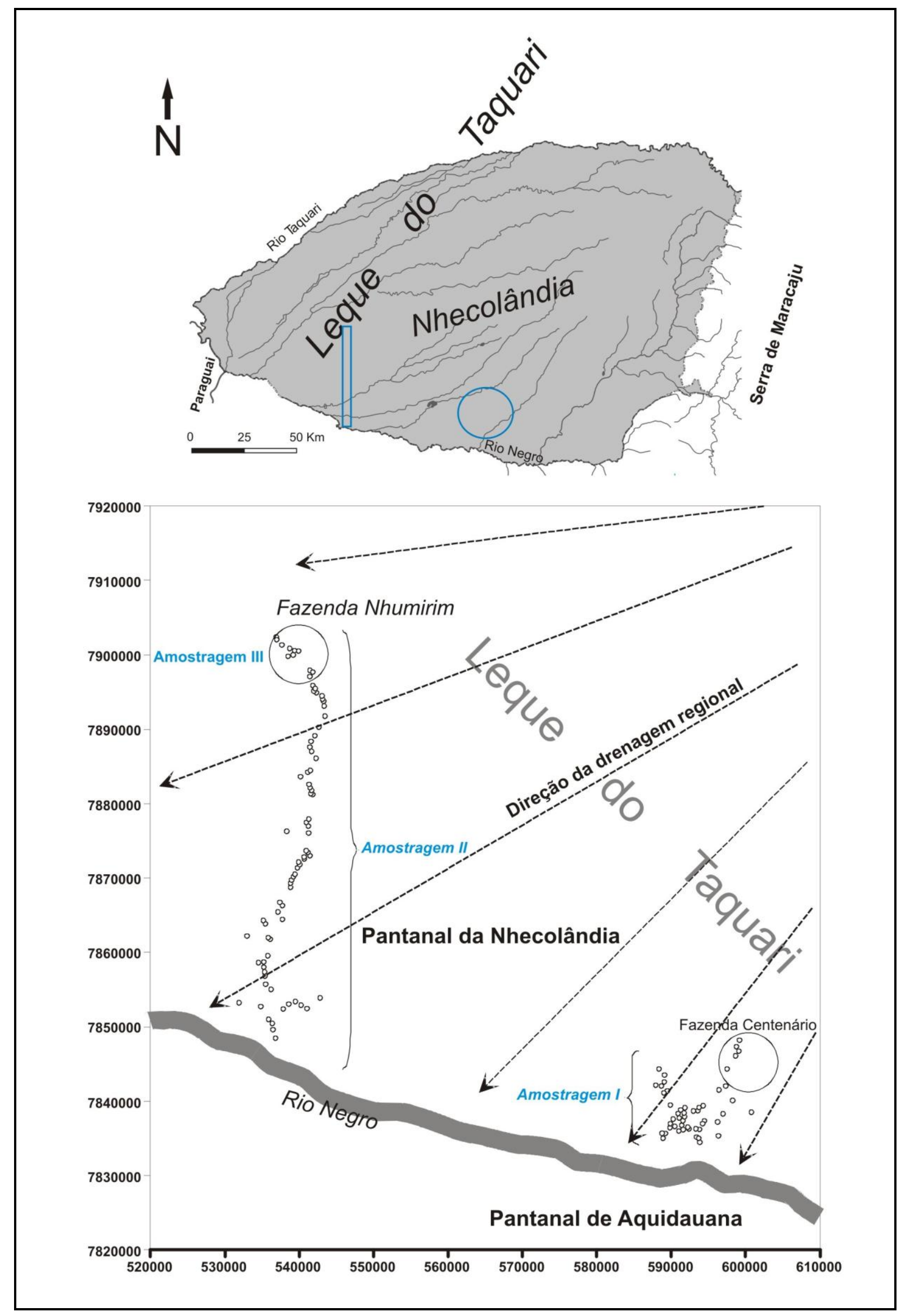

Figura 14. Localização das amostragens I, II e III no Pantanal da Nhecolândia. 
As medidas de $\mathrm{pH}$ e condutividade elétrica (CE) da água foram feitas in situ colocando-se o eletrodo diretamente na água, a aproximadamente $20 \mathrm{~m}$ da borda para o centro dos corpos d'água. Os aparelhos portáteis utilizados foram: pHmetro modelo HI 98140, condutivímetro modelo HI 9838 (ambos Hanna Instruments) e GPS modelo Holux m241. Paralelamente, coletaram-se amostras de águas, filtradas no local da amostragem com filtros de acetato de celulose de 0,45 $\mu \mathrm{m}$, e em seguida armazenadas em frascos de polietileno de $125 \mathrm{ml}$. Essas amostras foram preservadas ao abrigo da luz, e em temperatura de $4{ }^{\circ} \mathrm{C}$, para análises em laboratório da composição catiônica, aniônica, da alcalinidade e sílica. As análises químicas dos elementos maiores $\left(\mathrm{Cl}^{-}, \mathrm{SO}_{4}^{-2}, \mathrm{Alc}, \mathrm{Na}^{+}, \mathrm{K}^{+}, \mathrm{Mg}^{2+}\right.$ e $\left.\mathrm{Ca}^{2+}\right)$ foram realizadas no Laboratório de Ecologia Ambiental e Geoprocessamento (NUPEGELCENA-USP), segundo os procedimentos analíticos de rotina nesse laboratório.

Amostragem II - A segunda amostragem foi realizada por Mascré (2004), totalizando 74 amostras georeferenciadas. Elas foram coletadas ao longo de um segmento norte-sul, saindo da Fazenda Nhumirim (Embrapa Pantanal) ao norte, até as proximidades do Rio Negro, ao sul. Esse segmento interceptou a drenagem regional que é orientada, grosso modo, de NE a SE (Figura 14). A composição das águas em elementos maiores foi determinada no Laboratório de Geociência Ambiental (Toulouse/Fr).

Amostragem III - A terceira amostragem foi feita por Fernandez (2007) nas imediações da Fazenda Nhumirim, e totaliza 156 amostras não georeferenciadas. Desta amostragem não há análises químicas em laboratório, apenas medidas de CE e $\mathrm{pH}$ in situ no campo. 


\subsection{Tratamento dos dados}

\subsubsection{Análise em Componentes Principais (ACP)}

O objetivo dos tratamentos estatísticos pela análise em componentes principais (ACP) é identificar os eixos de variabilidade na composição química das águas superficiais da Nhecolândia, e hierarquizar os processos responsáveis por essa variabilidade. Esses tratamentos foram realizados somente com as amostragens I e II georeferenciadas, das quais se analisaram as variáveis $\mathrm{CE}, \mathrm{pH}$, $\mathrm{Na}^{+}, \mathrm{Ca}^{+}, \mathrm{Mg}^{2+}, \mathrm{K}^{+}, \mathrm{Cl}^{-}, \mathrm{SO}_{4}{ }^{2-}$ e alcalinidade.

Em função do número de amostras (147) e do número de variáveis analisadas (9), empregou-se a análise em componentes principais (ACP), que permite relacionar grande número de variáveis por suas dimensões comuns. Em outros termos, esta análise condensa informações em conjuntos menores de variáveis estatísticas, com perda mínima de informações (Anderson et al., 2005).

A ACP foi feita com base na matriz de correlação, em que as variáveis são normalizadas pela média e pelo desvio padrão. Disto decorrem 2 consequências (Rezende Filho, 2011), a saber:

$1^{\circ}$. Cada variável tem o mesmo peso, independente do tipo de unidade escolhida $\mathrm{mol} / \mathrm{L}, \mathrm{mmol} / \mathrm{L}, \mathrm{Meq} / \mathrm{L}, \mu \mathrm{S} / \mathrm{m}, \mu \mathrm{S} / \mathrm{cm}$. Consequentemente, pode-se tratar e comparar variáveis com unidades diferentes, sejam parâmetros físico-químicos (condutividade elétrica, temperatura, $\mathrm{Ca}^{2+}, \mathrm{Na}^{+}$dentre outros), sejam parâmetros sem unidade como o $\mathrm{pH}$.

$2^{\circ}$. Os eixos são ortogonais em um multi-espaço, e isto traduz, teoricamente, processos independentes entre si. 
A hierarquização dos processos associados a cada eixo fatorial é feita em função do valor próprio de cada eixo. Em geral, nas ciências da terra é difícil interpretar eixos fatoriais com valores inferiores a $10 \%$ da variabilidade total (Rezende Filho, 2011).

O objetivo é determinar os principais eixos de variabilidade, e a combinação linear " $X$ " de variáveis melhor associadas a esses eixos, pela fórmula:

$$
X=\alpha_{1} V_{1}+\alpha_{2} V_{2}+\ldots+\alpha_{n} V_{n}
$$

Onde $V_{i}$ são as variáveis e $\alpha_{i}$ os respectivos coeficientes.

Num segundo momento, a distribuição dessa combinação linear de variáveis foi estudada por meio de um tratamento geoestatístico.

\subsubsection{Tratamento geoestatístico dos resultados da ACP}

A combinação linear " $X$ " de variáveis determinada pela ACP corresponde a uma informação condensada, que expressa melhor a variabilidade química das águas de superfície da Nhecolândia. A distribuição espacial regional dessa variabilidade foi estudada nas seguintes etapas:

1․ Análise estatística descritiva (máximo, mínimo, média, variância, desvio padrão e coeficiente de variação). O objetivo foi visualizar o comportamento dos dados, e identificar a existência ou não de valores discrepantes que possam inviabilizar suas aplicações. Essa análise foi feita segundo as fórmulas:

\begin{tabular}{|l|l|}
\hline $\begin{array}{l}\text { Fórmula da Variância: } v=\frac{1}{n} \sum_{i=1}^{n}\left(x_{i}-\bar{x}\right)^{2} \\
\begin{array}{l}v=\text { variância } \\
\sum=\text { soma }\end{array}\end{array}$ & $\begin{array}{l}\text { Fórmula do Desvio Padrão: } \mathbf{S}=\sqrt{v} \\
v=\text { variância }\end{array}$ \\
$\begin{array}{l}x_{i}=\text { dado estatístico } \\
\bar{X}=\text { média dos dados estatísticos } \\
n=\text { número de amostras }\end{array}$ & \\
\hline
\end{tabular}


$2^{\circ}$. Análise da distribuição estatística por meio do histograma de distribuição. O objetivo é verificar se a distribuição estatística se aproxima de uma lei normal, requisito para o tratamento geoestatístico. Caso contrário, deve-se realizar uma transformação dos dados brutos para se aproximar de uma lei normal.

$3^{\circ}$. Estudo do semivariograma experimental e de suas características fundamentais: patamar, alcance, efeito pepita, contribuição.

$4^{\circ}$. Ajustamento de um modelo teórico de variograma pelo método dos mínimos quadrados.

$5^{\circ}$. Krigagem e representação cartográfica dos dados.

A seguir mostraremos com mais detalhe os procedimentos que envolvem o tratamento geoestatístico. Lembrando que um tratamento geoestatístico consiste na escolha, apresentação, análise e interpretação de dados georreferenciados por meio de um conjunto de técnicas para analisar e inferir valores de uma variável distribuída no espaço (Camargo, 1997). Portanto, os estudos de semivariogramas e suas características fundamentais, juntamente com as técnicas de krigagem, constituem a base do tratamento geoestatístico de dados georreferenciados.

\section{a) Semivariograma}

O semivariograma analisa o grau de dependência espacial entre amostras num campo experimental, e permite definir parâmetros necessários para estimar valores para locais não amostrados. O semivariograma pode ser estimado pela fórmula:

$$
\gamma(h)=\frac{1}{2 N(h)} \sum_{i=1}^{N(h)}\left(Z\left(x_{i}\right)-Z\left(x_{i}+h\right)\right)^{2}
$$


Onde: y (h) é o semivariograma estimado ou experimental; $h$ vetor distância média entre os pontos da classe; $N(h)$ o número de pares de pontos da classe e, z $\left(x_{i}\right)$ e $z\left(x_{i}+h\right)$ são os valores da variável coletados nos pontos $x_{i}$ e $x_{i}+h(i=1, \ldots, n)$ separados pelo vetor $h$.

Essa fórmula expressa a evolução da variabilidade da variável, estudada no campo experimental, em função da distância que separa os pontos amostrados. A análise dessa função é realizada por meio de quatro características fundamentais do semivariograma, isto é: o alcance, o patamar, o efeito pepita e a contribuição (Figura 15).

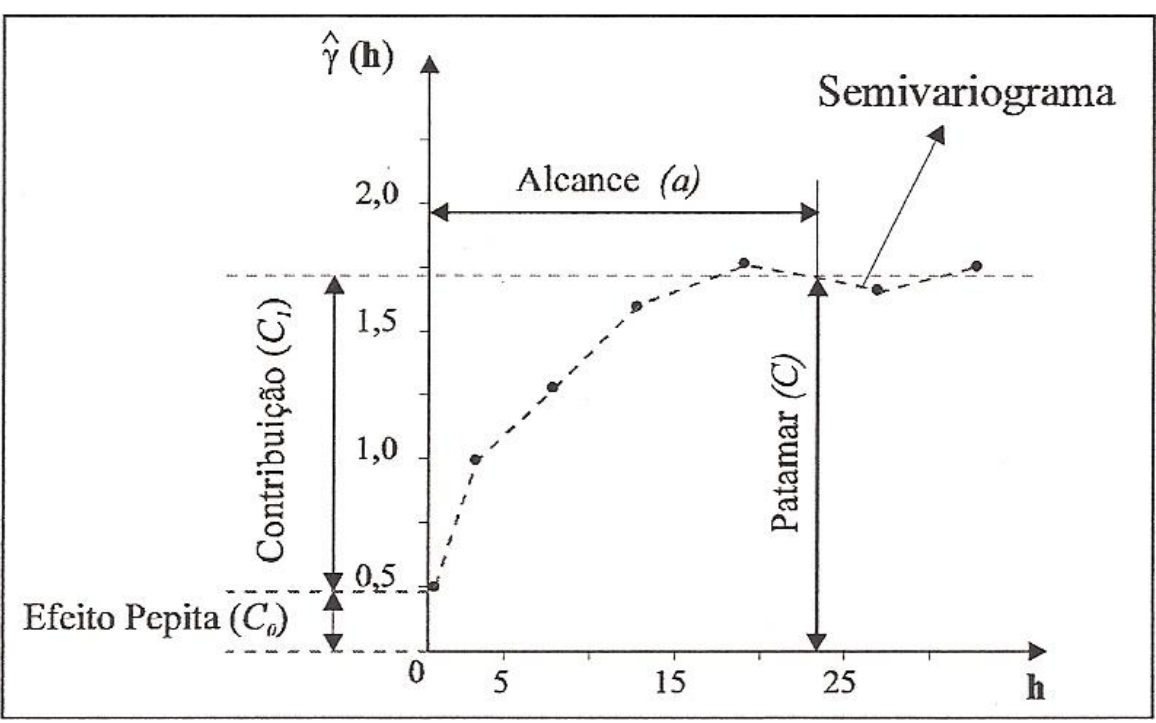

Figura 15. Características do semivariograma.

Alcance (a): $O$ alcance é a distância dentro da qual as amostras se apresentam correlacionadas espacialmente.

Patamar (C): O patamar é o valor do semivariograma que corresponde ao alcance (a). Deste valor em diante, considera-se que não existe mais dependência espacial entre as amostras, porque a variância da diferença entre pares de amostras $(\operatorname{Var}[z(x)-z(x+h])$ torna-se invariante com a distância. 
Efeito Pepita ( $\left.C_{0}\right):$ O efeito pepita é o valor positivo do semivariograma à medida que $\mathrm{h}$ tende para 0 (zero). Esse valor revela a descontinuidade do semivariograma para distâncias menores do que a menor distância entre as amostras. Dois fatores podem ser responsáveis pela presença de um efeito pepita:

$\left.1^{\circ}\right)$ instabilidade do aparelho utilizado para a aquisição dos valores (variável estudada), ou de suas localizações (georeferenciamento);

$2^{\circ}$ ) densidade de pontos de amostragem insuficiente para analisar espacialmente a variabilidade que ocorre a distâncias menores do que a menor distância entre as amostras.

Nem sempre é possível identificar o fator responsável pela presença de um efeito pepita, pois ele pode resultar de uma combinação desses dois fatores.

Contribuição $\left(\mathcal{C}_{1}\right)$ : A contribuição é a diferença entre o Patamar (C) e o Efeito Pepita $\left(\mathrm{C}_{0}\right)$.

A partir dessas características, a variância total de uma determinada propriedade é desmembrada em diferentes distâncias amostradas e, com isso, objetiva encontrar a estrutura da variância.

\section{b) Krigagem}

O método de Kriging, muitas vezes traduzido como Krigagem, é um método de regressão usado em geoestatística para aproximar ou interpolar dados. Ele parte do princípio que pontos próximos no espaço tendem a ter valores mais parecidos do que pontos mais afastados. Neste método, os pesos são atribuídos de acordo com a variabilidade espacial expressa no semivariograma (Vieira, 1998). Assim, a krigagem deve ser vista como uma otimização da interpolação, baseada na estrutura da variabilidade em função da distância de interpolação. 
De uma maneira prática, ele consiste em calcular a interpolação da variável estudada a partir de um modelo matemático ajustado ao variograma experimental. Geralmente, o ajustamento do modelo matemático teórico é realizado pelo método dos mínimos quadrados, muito empregado na geração de mapas de distribuição de variáveis no espaço.

\section{RESULTADOS}

\subsection{Estatística Descritiva}

Os resultados das análises estatísticas descritivas são apresentados na Tabela 1. Nota-se que a gama de condutividade elétrica é extensa, varia de 16 $\mu \mathrm{S} . \mathrm{cm}^{-1}$ a $60 \mu \mathrm{S} . \mathrm{cm}^{-1} . \mathrm{O} \mathrm{SO}_{4}{ }^{2-}$ apresenta o maior coeficiente de variação $(3,42)$, e em seguida aparecem o $\mathrm{Na}^{+}(3,36)$, a Alc $(3,24)$, a CE $(3,10)$, o $\mathrm{Cl}^{-}(2,82)$, e o $\mathrm{K}^{+}$ (2,69). $\mathrm{O} \mathrm{Mg}^{2+}$ e o $\mathrm{Ca}^{2+}$ apresentam coeficientes de variação bem menores, de 1,19 e 1,16 respectivamente.

Tabela 1. Estatística descritiva das variáveis (Amostragens I e II = 147 amostras).

\begin{tabular}{cccccccc}
\hline Variável & Unidade & Mínimo & Máximo & Média & $\begin{array}{c}\text { Variância } \\
\mathbf{v}^{*}\end{array}$ & $\begin{array}{c}\text { Desvio } \\
\text { Padrão }\end{array}$ & $\begin{array}{c}\text { Coef. de } \\
\text { variação }\end{array}$ \\
\hline $\mathbf{p H}$ & - & 5,6 & 9,95 & 7,4 & 1,35 & 1,16 & 0,15 \\
$\mathbf{C E}$ & $\mu \mathrm{S} \cdot \mathrm{cm}^{-1}$ & 16 & 60400 & 2302 & 51255986 & 7183 & 3,10 \\
$\mathbf{C l}$ & $\mathrm{mmol} / \mathrm{L}$ & 0,011 & 49 & 1,9 & 28 & 5,35 & 2,82 \\
$\mathbf{S O}_{4}{ }^{2-}$ & $\mathrm{mmol} / \mathrm{L}$ & 0,007 & 42,5 & 1,6 & 29 & 5,44 & 3,42 \\
$\mathbf{A l c}^{-}$ & $\mathrm{mmol}$ & 0,102 & 511 & 19 & 3798 & 61,8 & 3,24 \\
$\mathbf{N a}^{+}$ & $\mathrm{mmol} / \mathrm{L}$ & 0,037 & 537 & 18,6 & 3941 & 63 & 3,36 \\
$\mathbf{K}^{+}$ & $\mathrm{mmol} / \mathrm{L}$ & 0,035 & 65,4 & 3,1 & 72 & 8,5 & 2,69 \\
$\mathbf{M g}^{2+}$ & $\mathrm{mmol} / \mathrm{L}$ & 0,032 & 3,1 & 0,35 & 0,18 & 0,42 & 1,19 \\
$\mathbf{C a}^{2+}$ & $\mathrm{mmol} / \mathrm{L}$ & 0,037 & 3,7 & 0,48 & 0,32 & 0,57 & 1,16 \\
\hline
\end{tabular}

\subsection{Matriz de Correlação}

A matriz de correlação é apresentada na Tabela 2. Há fortes correlações positivas entre Condutividade Elétrica (CE) e Sódio (0,999), CE e Alcalinidade 
$(0,998)$, e CE e Potássio $(0,984)$. Secundariamente, também se observa boa correlação entre CE e Cloreto $(0,882)$, e Sulfato $(0,859)$. Isto indica que as águas com cargas mais elevadas apresentam maiores teores desses elementos químicos.

Tabela 2. Matriz de correlação das variáveis (147 amostras).

\begin{tabular}{cccccccccc}
\hline Variáveis & $\mathbf{p H}$ & $\mathbf{C E}$ & $\mathbf{C l}$ & $\mathbf{S O}_{4}{ }^{2-}$ & $\mathbf{A l c}$ & $\mathbf{N a}^{+}$ & $\mathbf{K}^{+}$ & $\mathbf{M g}^{2+}$ & $\mathbf{C a}^{2+}$ \\
\hline $\mathbf{p H}$ & 1,000 & & & & & & & & \\
$\mathbf{C E}$ & 0,505 & 1,000 & & & & & & & \\
$\mathbf{C l}^{-}$ & 0,535 & $\mathbf{0 , 8 8 2}$ & 1,000 & & & & & & \\
$\mathbf{S O}_{4}{ }^{2-}$ & 0,418 & $\mathbf{0 , 8 5 9}$ & 0,721 & 1,000 & & & & & \\
$\mathbf{A l c}^{+}$ & 0,490 & $\mathbf{0 , 9 9 8}$ & 0,865 & 0,841 & 1,000 & & & & \\
$\mathbf{N a}^{+}$ & 0,490 & $\mathbf{0 , 9 9 9}$ & 0,884 & 0,858 & $\mathbf{0 , 9 9 8}$ & 1,000 & & & \\
$\mathbf{K}^{+}$ & 0,531 & $\mathbf{0 , 9 8 4}$ & 0,848 & 0,851 & $\mathbf{0 , 9 8 3}$ & 0,978 & 1,000 & & \\
$\mathbf{M g}^{2+}$ & 0,210 & 0,017 & 0,038 & 0,125 & 0,003 & $-0,002$ & 0,040 & 1,000 & \\
$\mathbf{C a}^{2+}$ & 0,285 & 0,035 & 0,051 & 0,204 & 0,014 & 0,016 & 0,055 & 0,824 & 1,000 \\
\hline
\end{tabular}

\subsection{Eixos Fatoriais}

O valor próprio de cada eixo fatorial está apresentado na Tabela 3. Os 2 primeiros eixos fatoriais, F1 e F2, representam, respectivamente, 64,98 \% e $21,15 \%$ da variância total explicada. Portanto, o primeiro plano fatorial explica até $86,14 \%$ da variância total da amostragem (Figura 17). Nota-se também que a partir do terceiro eixo a porcentagem da variância explicada é inferior a $10 \%$, tornando difícil interpretá-lo. Por isto, considerou-se apenas o primeiro plano.

Tabela 3. Análise em componentes principais - valores próprios.

\begin{tabular}{cccc}
\hline Eixos Fatoriais & Valor Próprio & $\begin{array}{c}\text { Variância } \\
\text { Explicada (\%) }\end{array}$ & $\begin{array}{c}\text { Percentagem } \\
\text { Acumulada }\end{array}$ \\
\hline F1 & 5,84 & $\mathbf{6 4 , 9 8}$ & 64,98 \\
F2 & 1,90 & $\mathbf{2 1 , 1 5}$ & 86,13 \\
F3 & 0,65 & $\mathbf{7 , 2 3}$ & 93,37 \\
\hline
\end{tabular}

As Figuras 16 e 17 mostram a repartição das amostras e das variáveis no primeiro plano fatorial da ACP. Observam-se, claramente, dois conjuntos de variáveis associados ao primeiro e ao segundo eixo fatorial. O primeiro conjunto, 


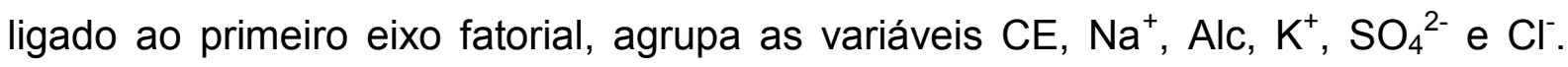
Este agrupamento concorda com a correlação positiva que essas variáveis apresentam na matriz de correlação (Tabela 2). O segundo conjunto, associado ao segundo eixo fatorial, é constituído pelas variáveis $\mathrm{Ca}^{2+}$ e $\mathrm{Mg}^{2+}$. $\mathrm{O} \mathrm{pH}$ está em posição intermediária entre os dois conjuntos de variáveis, e com um peso bem menor do que a CE no resultado da ACP.

O primeiro plano fatorial, com $86 \%$ da variância, destaca o peso da carga química total das águas na variabilidade química regional. Estes dados confirmam os resultados apresentados para a Nhecolândia, a partir de estudos realizados em escalas local e regional (Barbiéro et al., 2002, 2008, Rezende Filho et al., 2012), e justificam a análise do comportamento dos elementos químicos nas águas submetidas à concentração por evaporação.

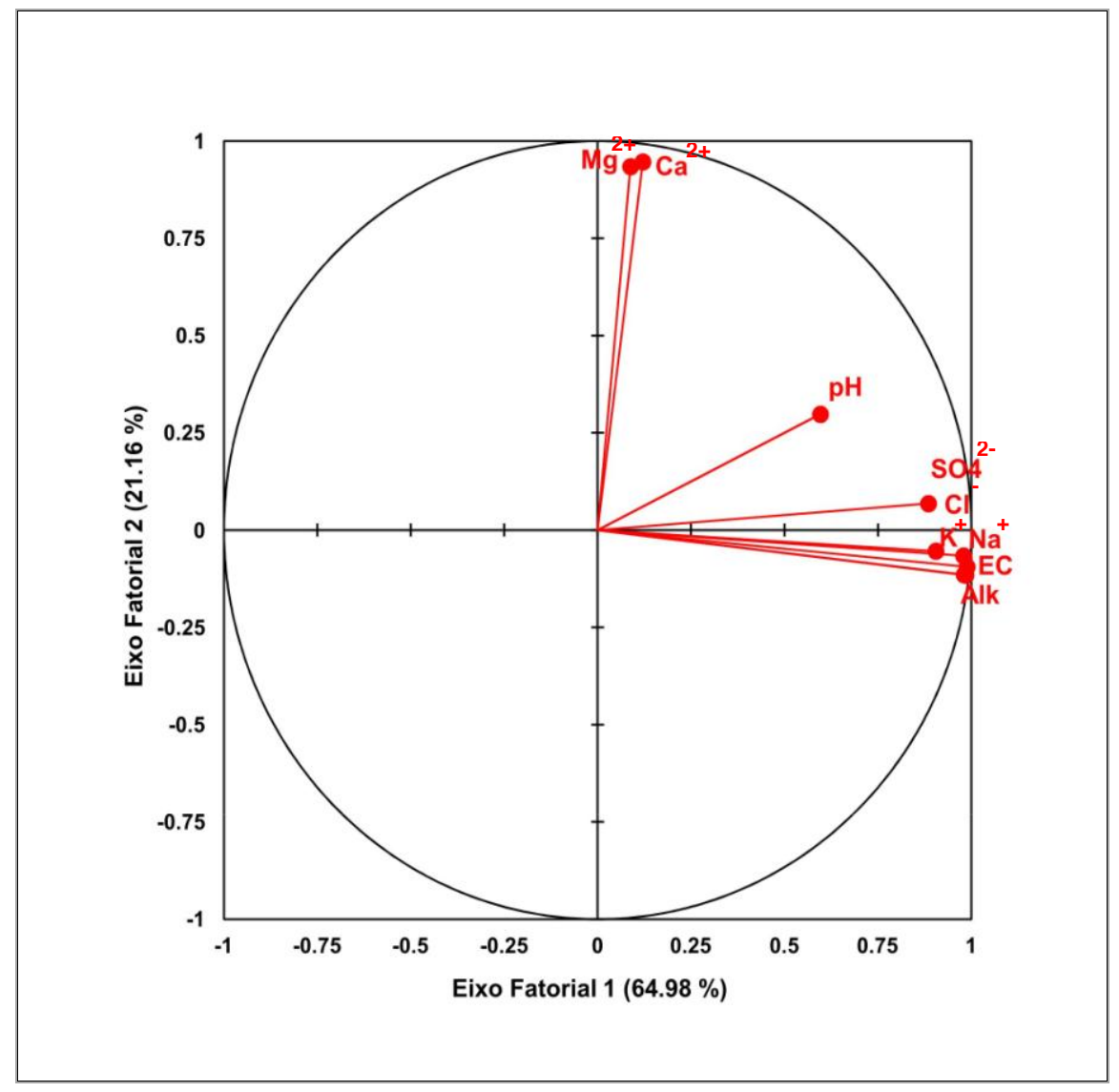

Figura 16. Distribuição das variáveis no primeiro plano fatorial da ACP. 


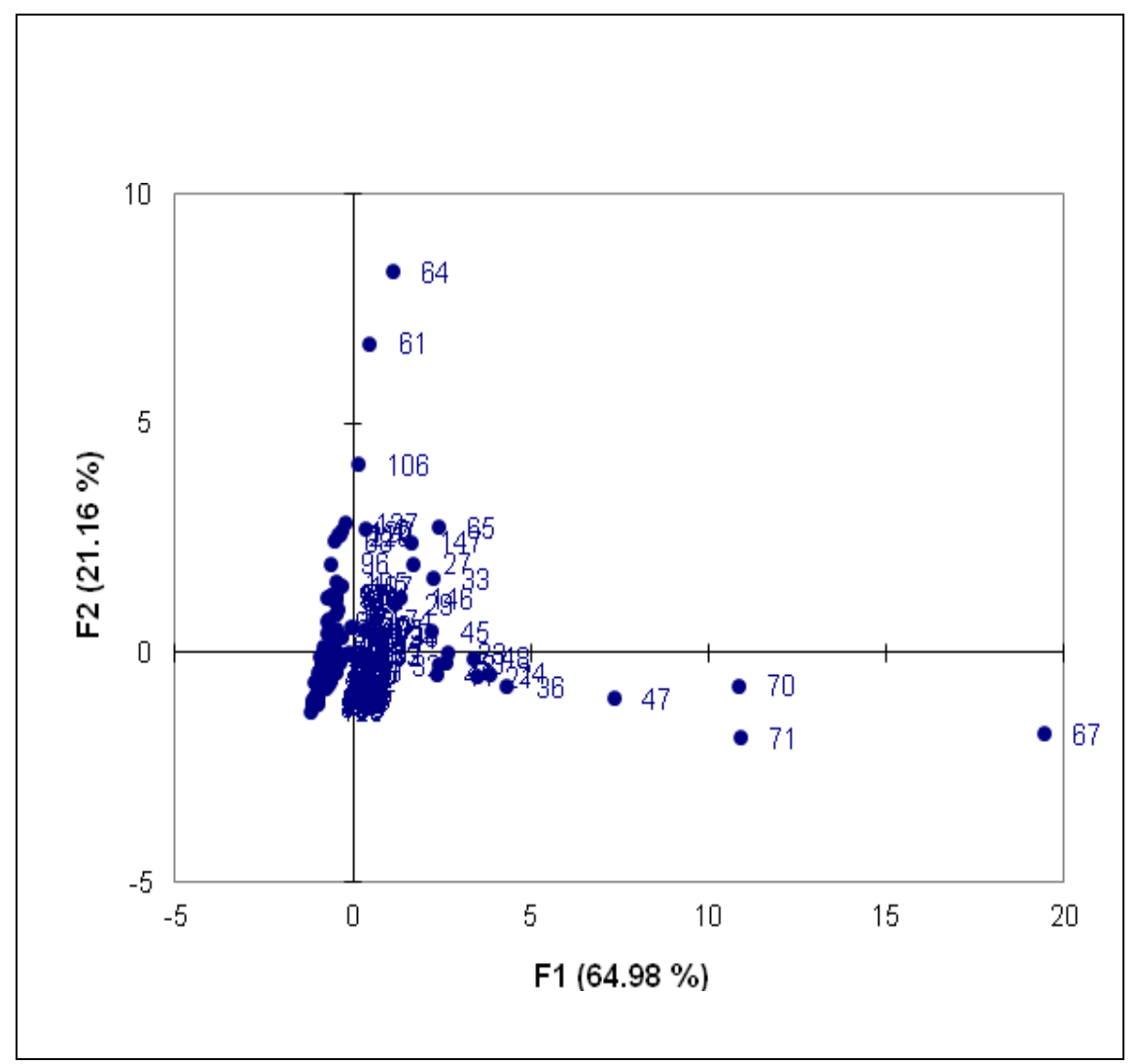

Figura 17. Distribuição das amostras e das variáveis no primeiro plano fatorial da ACP.

\subsection{Diagramas de concentração}

Os diagramas de concentração foram construídos a partir das amostragens de águas I e II, e dos teores em $\mathrm{Na}^{+}$, a fim de avaliar a concentração relativa essas águas (Figura 18). Apesar de certa dispersão das nuvens de pontos, a concentração dos elementos é proporcional ao fator de concentração para os valores de $\mathrm{Na}^{+}$até 5 $\mathrm{mmol}_{\mathrm{c}}$. Para concentrações maiores em sódio, nota-se um aumento proporcional de

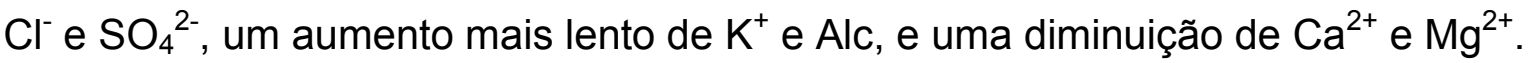

Esse tipo de comportamento dos íons é comum na Nhecolândia. Ele já havia sido identificado em outras pesquisas, que o relacionaram à precipitação de calcita magnesiana, de silicatos de magnésio e potássio (Furquim, 2007; Furquim et al., 2008). 


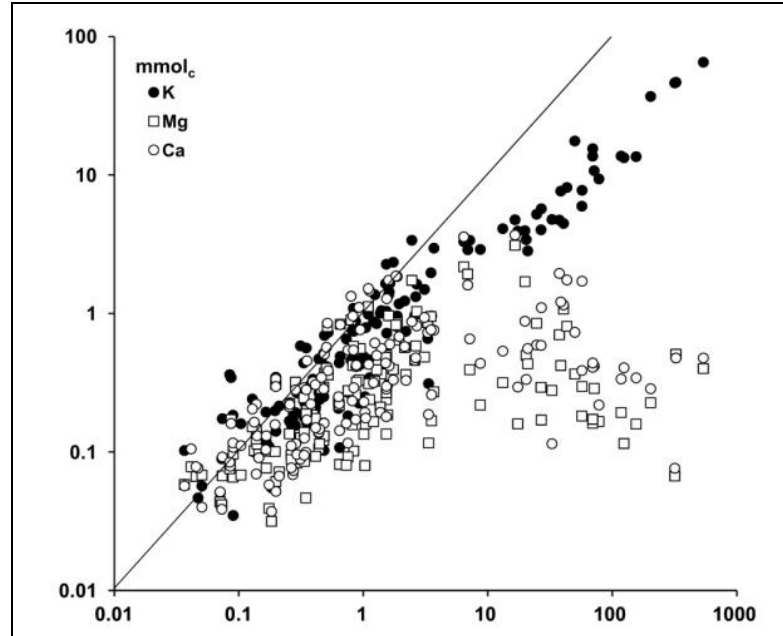

(a)

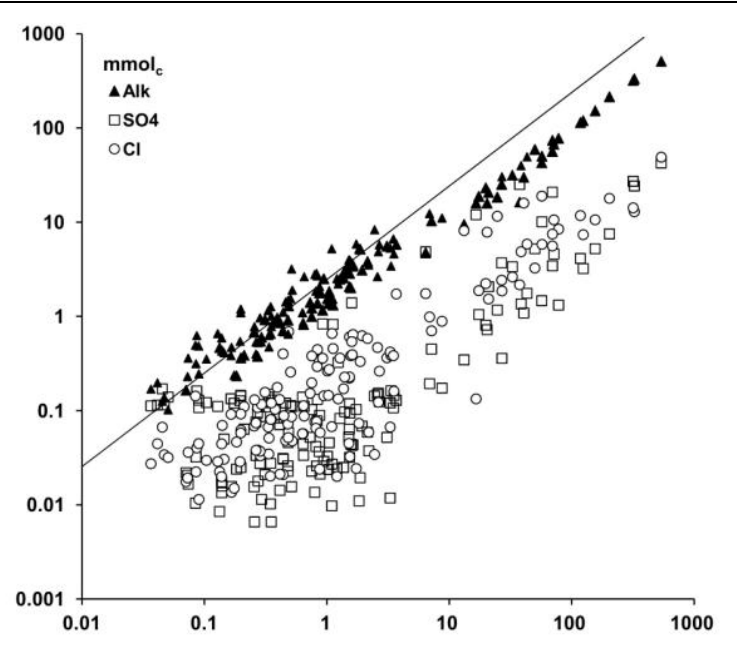

(b)

Figura 18. Diagrama de concentração: (a) cátions e (b) ânions.

Esses resultados, diagramas e ACP, mostram que o segundo eixo fatorial da ACP traduz um controle do $\mathrm{Ca}^{2+}$ e do $\mathrm{Mg}^{2+}$ pelas precipitações salinas, Mg-Calcita e Mg-Silicatos, durante a concentração das águas por evaporação. Isto indica que os dois primeiros eixos fatoriais ressaltam a variabilidade química decorrente do processo de evaporação das águas: de um lado, pelo aumento da concentração de vários elementos na solução, e de outro, pelo controle de $\mathrm{Ca}^{2+}$ e $\mathrm{Mg}^{2+}$ pelas precipitações salinas. Portanto, a variável CE, nitidamente associada ao eixo 1 da ACP, também expressa a variabilidade explicada pelo eixo 2 . Consequentemente, a CE é uma variável que representa a soma das variâncias explicadas pelos dois eixos fatoriais, equivalente a $86 \%$ da variância total.

Em função disto, a combinação linear de variáveis "X" pesquisada (1) pode ser reduzida a uma expressão simples:

$$
\mathrm{X}=1 \mathrm{CE}
$$


Em síntese, isso permite usar a variável CE nas análises geoestatísticas, visando entender a distribuição da variabilidade química das águas na região, a seguir apresentadas.

\section{DISCUSSÃO DOS RESULTADOS}

\subsection{Distribuição estatística das amostragens I, II e III.}

O estudo integrado da ACP com os diagramas de concentração permitiu associar a variável CE a aproximadamente $86 \%$ da variabilidade química regional das águas. Este resultado facilita o estudo da distribuição estatística dessa variabilidade, e permite incorporar ao conjunto de amostras as águas da amostragem III, dando maior amplitude a este estudo.

A gama dos valores de salinidade observada é extensa, varia de 16 a 71000 $\mu S . \mathrm{cm}^{-1}$, e ultrapassa a gama de salinidade da água estabelecida inicialmente por Richards (1954), para classificar águas de irrigação. Isto significa que as águas de superfície da Nhecolândia cobrem uma grande gama de carga iônica.

Se enquadrarmos essa gama de valores de CE na classificação de Richards (1954), 181 amostras se encaixam na classe hipohalina (CE de 0 a $750 \mu$ S.cm ${ }^{-1}$ ), e 126 na classe de águas salinas ou hipersalinas (CE acima de $750 \mu$ S.cm ${ }^{-1}$ ).

O histograma apresentado na Figura 19-a indica que mais de $85 \%$ das amostras têm valores de CE abaixo de $2500 \mu \mathrm{S} . \mathrm{cm}^{-1}$, e isto corresponde à faixa dos menores valores da gama. A repartição geral de todos os valores de CE não se enquadra na distribuição estatística dita "normal", e por isto não pode ser diretamente utilizada para espacialização dessa variável. Para isto foi necessário fazer uma transformação logarítmica dos dados de CE em $\log _{10}(C E)$, a fim de ajustá-los a uma distribuição normal. 

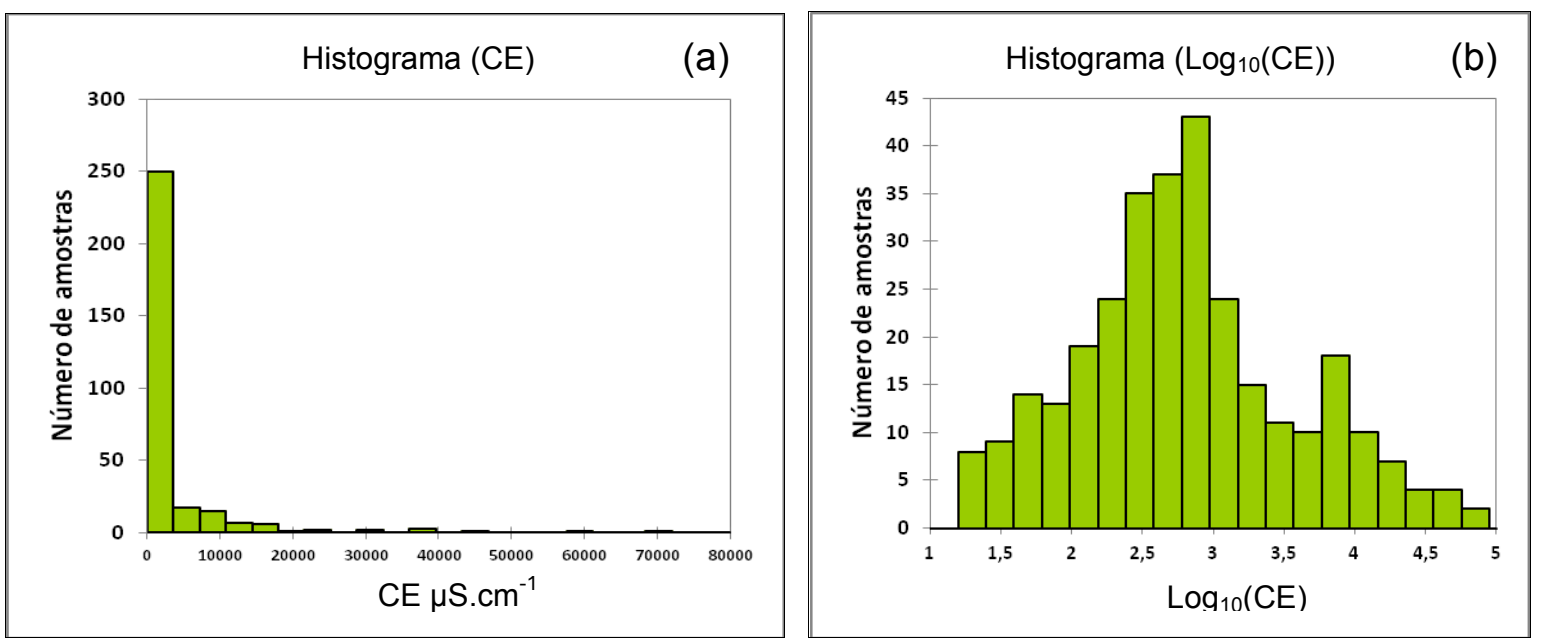

Figura 19. Histogramas: (a) da variável CE e (b) de $\log _{10}(C E)$.

O histograma da Figura 19-b mostra a distribuição do $\log _{10}(C E)$. Nota-se que a transformação da variável CE em $\log _{10}(\mathrm{CE})$ detalha melhora distribuição dos valores que compõem a gama de condutividade elétrica observada. Por isto, empregou-se o $\log _{10}(\mathrm{CE})$ para analisar a distribuição espacial da condutividade elétrica.

O histograma (19-b) tem característica bimodal bem marcada, com uma primeira moda centralizada no valor $\log _{10}(C E)$ de 2,8 , equivalente a uma condutividade elétrica de $600 \mu \mathrm{S} . \mathrm{cm}^{-1}$, de maior frequência. A segunda moda se centraliza no valor 3,7 , e equivale a uma condutividade elétrica de $5.000 \mu S . \mathrm{cm}^{-1}$, de menor frequência. Essa distribuição destaca ausência, na amostragem realizada, de lagoas com valores intermediários de $\log _{10}(C E)$, de 3,3 a 3,5, equivalentes à faixa de condutividade elétrica entre 2.000 e $3.000 \mu$ S. $\mathrm{cm}^{-1}$.

No primeiro plano fatorial da $\mathrm{ACP}$ a variável $\mathrm{pH}$ se localiza em posição intermediária entre os dois primeiros eixos. Nessa posição, o pH provavelmente expressa a influencia de um outro fator fortemente relacionado ao eixo fatorial 1 , não ligado à mineralização das águas. $\mathrm{O}$ estudo da relação $\log _{10}(\mathrm{CE})$ e $\mathrm{pH}$ mostra uma 
boa correlação dessas variáveis, pois o pH aumenta gradualmente em função da condutividade (Figura 20).

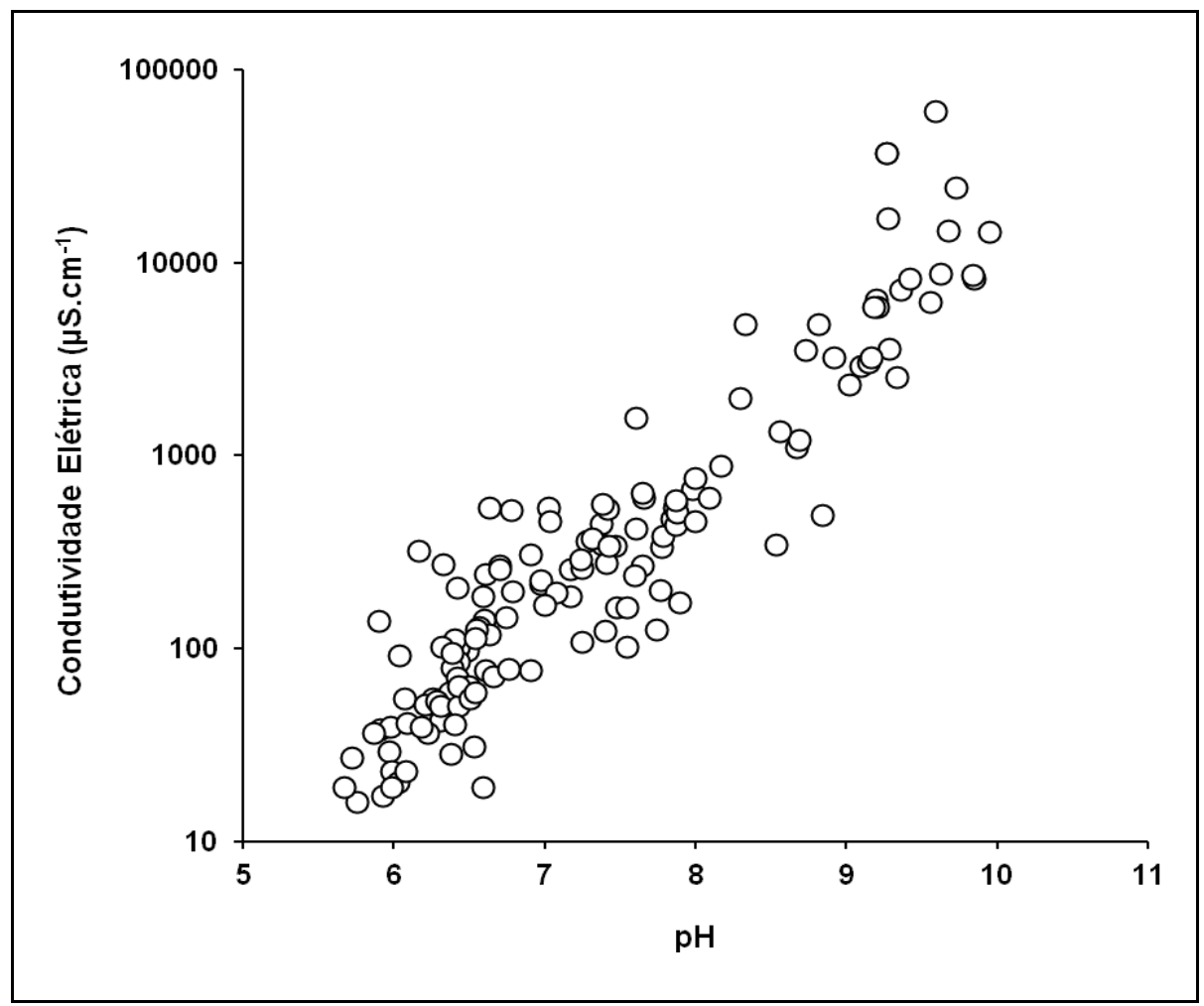

Figura 20. Correlação do $\log _{10}$ (CE) e pH (307 amostras).

Isto confirma que a variável $\log _{10}(\mathrm{CE})$ representa a variabilidade dos eixos 1 e 2, mas também que a variabilidade do $\mathrm{pH}$ e do $\log _{10}(\mathrm{CE})$ está ligada a um mesmo e único processo, isto é, à concentração das águas por evaporação.

A Tabela 4 apresenta os resultados das análises estatísticas descritivas do $\log _{10}(C E)$. Nota-se que os valores do desvio padrão $(0.769)$ e do coeficiente de variação (0.274) colocam em evidência grande variabilidade na amostragem, e confirmam a heterogeneidade dos dados. 
Tabela 4. Estatística descritiva.

\begin{tabular}{lc}
\hline \multicolumn{1}{c}{ Variáveis } & $\log _{10}(\mathrm{CE})$ \\
\hline $\mathrm{N}^{\circ}$ de Observações & 307 \\
Mínimo & 1,204 \\
Máximo & 4.851 \\
Média & 2.804 \\
Variância (n) & 0.590 \\
Desvio Padrão & 0.769 \\
Coeficiente de variação & 0.274 \\
\hline
\end{tabular}

\subsection{Semivariograma da variável $\log _{10}(C E)$}

Como os dados da amostragem III não foram georeferenciados, a análise da distribuição espacial da variável $\log _{10}(C E)$ foi baseada somente nas amostragens I e II. O semivariograma experimental na Figura 21 se caracteriza pela ausência de efeito pepita e um alcance muito baixo, inferior a $200 \mathrm{~m}$, mostrando que a curtas distâncias se atinge a variabilidade máxima.

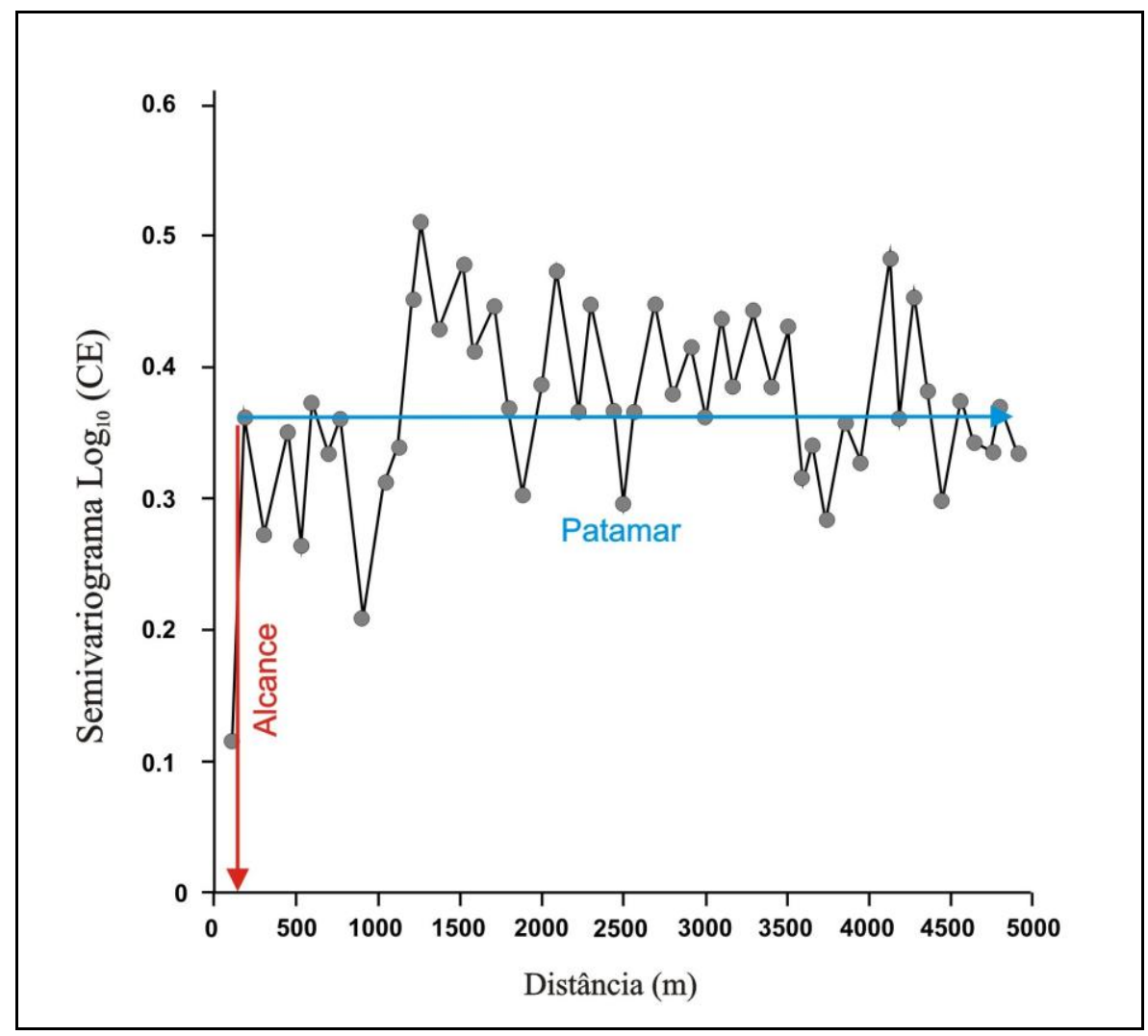

Figura 21. Semivariograma do $\log _{10}(C E)$. 
A configuração do semivariograma indica ausência de dependência da variável $\log _{10}(C E)$ para distâncias superiores a $200 \mathrm{~m}$. Como o valor de $200 \mathrm{~m}$ corresponde, aproximadamente, ao tamanho das lagoas, os dados só podem ser extrapolados em outros pontos de uma mesma lagoa, desde que seu tamanho não exceda 200 m. A partir de 200 m a semivariância atinge um patamar relativamente estável, que indica não existir um padrão espacial de distribuição da condutividade elétrica das águas de superfície na região. A impossibilidade de extrapolar os dados para distâncias superiores a $200 \mathrm{~m}$ influi na maneira de representar, em mapas, a distribuição da variável $\log _{10}(C E)$.

\subsection{Expressão espacial da distribuição}

O estudo do semivariograma mostrou que apesar de tratar-se de uma variável numérica os valores de $\log _{10}(\mathrm{CE})$ não podem ser extrapolados. A primeira consequência disto é a impossibilidade de produzir mapas, com base na extrapolação de valores, e em curvas de isovalores. Neste caso, o único tipo de representação cartográfica possível é por meio de classes pontuais de valores. A Figura 22 apresenta um exemplo a partir da amostragem I feita ao norte de Aquidauana (MS).

Para esse exemplo, definiu-se um total de 20 classes, numa tentativa de abranger toda gama de condutividade elétrica observada. As classes são apresentadas na Tabela 5, e a Figura 22 apresenta graficamente seus agrupamentos em 10 intervalos, cada qual representado por cores diferentes.

Essa representação cartográfica das classes de CE obtidas neste trabalho mostra que a salinidade não apresenta um padrão de organização espacial na área estudada na Nhecolândia. 
Tabela 5. Classes de condutividade elétrica $\left(\log _{10}(C E)\right)$.

\begin{tabular}{ccccc}
\hline \multicolumn{2}{c}{ Limite Inferior } & \multicolumn{2}{c}{ Limite Superior } & Frequência \\
\hline Log $_{10}(\mathrm{CE})$ & $\mathrm{CE}$ & $\log _{10}(\mathrm{CE})$ & $\mathrm{CE}$ & \\
\hline 1 & 0 & 1,194052 & 3050 & 0,000 \\
1,194052 & 3050 & 1,388104 & 6100 & 0,054 \\
1,388104 & 6100 & 1,582156 & 9150 & 0,048 \\
1,582156 & 9150 & 1,776207 & 12200 & 0,102 \\
1,776207 & 12200 & 1,970259 & 15250 & 0,075 \\
1,970259 & 15250 & 2,164311 & 18300 & 0,122 \\
2,164311 & 18300 & 2,358363 & 21350 & 0,088 \\
2,358363 & 21350 & 2,552415 & 24400 & 0,116 \\
2,552415 & 24400 & 2,746467 & 27450 & 0,116 \\
2,746467 & 27450 & 2,940518 & 30500 & 0,054 \\
2,940518 & 30500 & 3,13457 & 33550 & 0,027 \\
3,13457 & 33550 & 3,328622 & 36600 & 0,014 \\
3,328622 & 36600 & 3,522674 & 39650 & 0,048 \\
3,522674 & 39650 & 3,716726 & 42700 & 0,027 \\
3,716726 & 42700 & 3,910778 & 45750 & 0,034 \\
3,910778 & 45750 & 4,10483 & 48800 & 0,027 \\
4,10483 & 48800 & 4,298881 & 51850 & 0,020 \\
4,298881 & 51850 & 4,492933 & 54900 & 0,007 \\
4,492933 & 54900 & 4,686985 & 57950 & 0,014 \\
4,686985 & 57950 & 4,881037 & 61000 & 0,007 \\
\hline
\end{tabular}




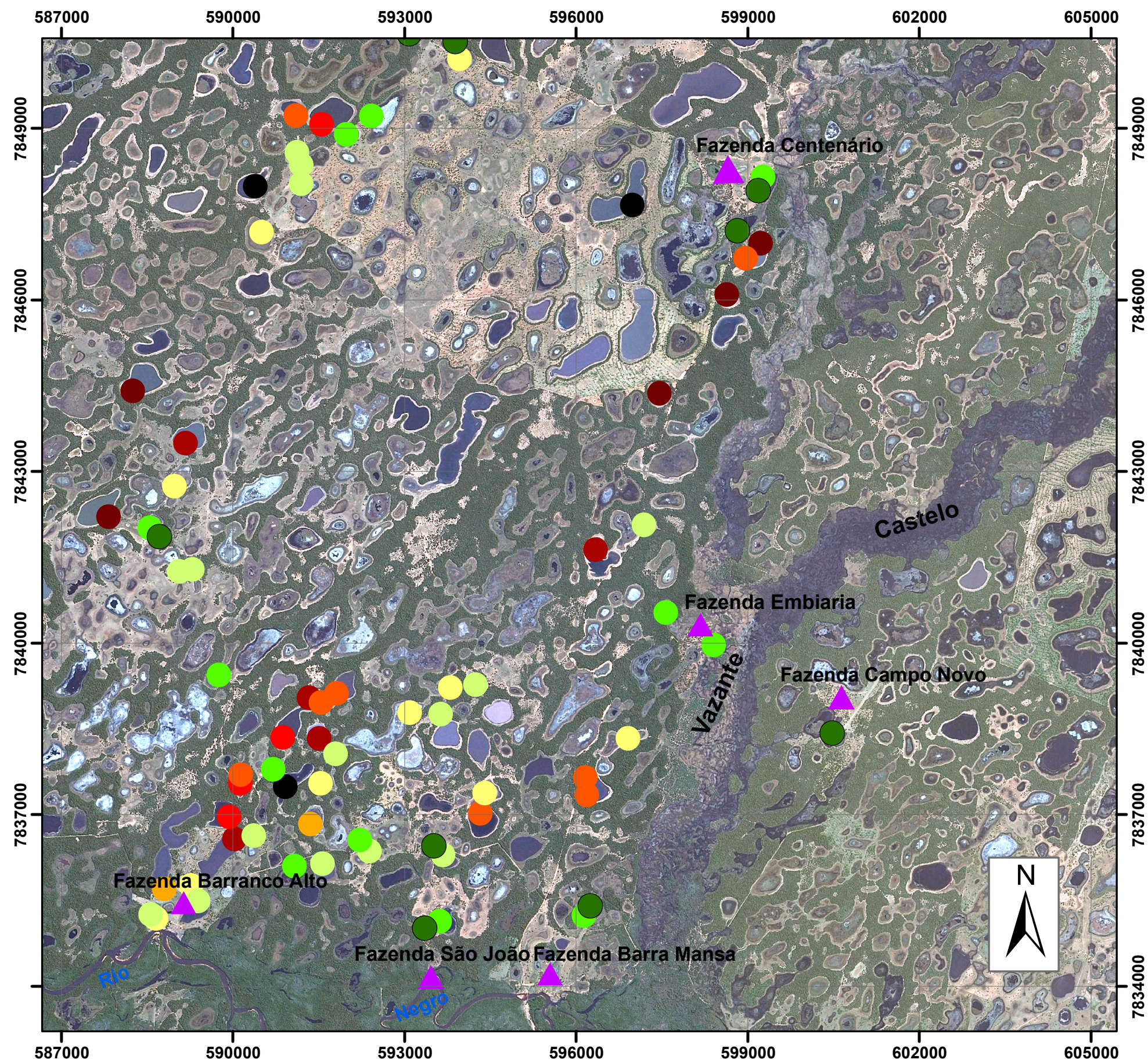

Figura 22. Classes de CE das águas de salinas $e$ baías na Nhecolândia/MS.

\section{Legenda}

Classes de CE:

$42-107$

$108-226$

O $227-360$

○ $361-635$

○ $636-1098$

$1099-3220$

$3221-4750$

$4751-8650$

$8651-24350$

24351-60400

$\triangle$ Sedes das Fazendas

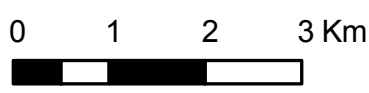

Projeção Universal Transversa de Mercator Fuso $21 \mathrm{~S}$. Datum Horizontal Córrego Alegre.

Elaboração: Elisângela R. C. Martins. 2012. Fonte: Imagem Google Earth/2010. 


\section{CONSIDERAÇÕES GERAIS}

Um dos objetivos deste estudo foi identificar os eixos e os processos de variabilidade química das águas da Nhecolândia, a partir de amostragens de águas (147 amostras), e suas análises físico-químicas.

O primeiro plano fatorial da ACP, formado pelos eixos 1 e 2 , explicou até $86 \%$ da variabilidade total, o que é considerável. Os dois principais eixos fatoriais traduzem: (i) o primeiro, a concentração das soluções pela evaporação, (ii) o segundo, o controle do $\mathrm{Ca}^{2+}$ e do $\mathrm{Mg}^{2+}$ durante a concentração. Esses dois eixos estão ligados a um único processo, que é a salinização das águas por evaporação. Assim, a variável CE pode substituir a combinação linear " $X$ " de variáveis no estudo da distribuição espacial da variabilidade química das águas na Nhecolândia. Por outro lado, a distribuição estatística da CE exige uma transformação logarítmica $\log _{10}(\mathrm{CE})$ dessa variável.

O estudo regional da condutividade elétrica das águas superficiais da Nhecolândia revela quatro pontos fundamentais:

$\left.1^{\circ}\right)$ ocorrência de elevadas gamas de condutividade elétrica;

$2^{\circ}$ ) boa correlação entre pH e CE da água;

$\left.3^{\circ}\right)$ presença de valores de alcance muito baixos (<200 m);

$4^{\circ}$ ) distribuição bimodal do $\log _{10}(\mathrm{CE})$, com duas modas bem distintas, a primeira de maior frequência com CE de $600 \mu \mathrm{S} . \mathrm{cm}^{-1}$, e a segunda, de menor frequência, com CE de $5000 \mu \mathrm{S} . \mathrm{cm}^{-1}$.

Estes quatro pontos serão considerados a seguir. 


\subsection{Elevadas gamas de condutividade elétrica e pH.}

Cabe lembrar que a identificação de extensas gamas de condutividade elétrica e de pH nas águas superficiais da Nhecolândia não é uma especificidade deste estudo. Ao contrário, estes resultados vêm corroborar os de vários autores que trabalharam nessa região (Tabela 6). Conclui-se, portanto, que elas são características das águas superficiais da Nhecolândia (Barbiéro et al., 2002; Fernandes, 2007; Mariot et al., 2007; Barbiéro et al., 2008; Furquim et al., 2008, 2010 a e b; Rezende Filho, 2011).

Tabela 6. Gamas de CE e pH identificadas na Baixa Nhecolândia.

\begin{tabular}{ccccc}
\hline Autores & pH (mín) & pH (máx) & CE (mín) & CE (máx) \\
\hline Barbiéro et al. (2002) & 7.1 & 9.8 & $20 \mu \mathrm{S} . \mathrm{cm}^{-1}$ & $4.000 \mu \mathrm{S} . \mathrm{cm}^{-1}$ \\
Fernandes (2007) & 5,51 & 10,32 & $29 \mu \mathrm{S} . \mathrm{cm}^{-1}$ & $68.100 \mu \mathrm{S} . \mathrm{cm}^{-1}$ \\
Mariot et al. (2007) & 6.6 & 9.8 & $150 \mu \mathrm{S} . \mathrm{cm}^{-1}$ & $75.000 \mu \mathrm{S} . \mathrm{cm}^{-1}$ \\
Furquim et al. (2008) & 5.5 & 10.5 & $20 \mu \mathrm{S} . \mathrm{cm}^{-1}$ & $20.000 \mu \mathrm{S} . \mathrm{cm}^{-1}$ \\
Presente estudo & 5.9 & 9.95 & $42 \mu \mathrm{S} . \mathrm{cm}^{-1}$ & $24.350 \mu \mathrm{S} . \mathrm{cm}^{-1}$ \\
\hline
\end{tabular}

Em decorrência desta concordância, pode-se considerar que a amostragem realizada neste trabalho é representativa da Nhecolândia, e que o processo responsável pela variabilidade espacial da CE atua em escala regional.

Levando-se em conta essa extensa gama de CE e as condições climáticas atuais, com precipitação média anual de $1100 \mathrm{~mm}$ e evaporação média anual de $1300 \mathrm{~mm}$ (ETP/P cerca de 1.3), percebe-se que elas não favorecem nem a acumulação de sais nem a manutenção da salinidade na paisagem. Em função disto, podem-se considerar duas hipóteses não exclusivas: 
$\left.1^{a}\right)$ que o processo responsável pela salinidade é bastante poderoso: ele poderia ser decorrente da presença de um estoque de sal acumulado em fases secas anteriores, mas que ainda afetaria, localmente, a química da água.

$2^{\mathrm{a}}$ ) que o efeito desse processo é acumulativo no tempo, de ano para ano: a distribuição atual da salinidade na paisagem poderia ser decorrente de prolongados anos de funcionamento desse sistema de lagoas. Contudo, sabe-se hoje, que a condição básica para manter a salinidade é o isolamento das águas salinas dos fluxos atuais, e anuais, das águas superficiais pouco mineralizadas das cheias do Pantanal.

A correlação $\mathrm{pH}$ e $\log _{10}(\mathrm{CE})$ é concordante com dados obtidos em pesquisas anteriores realizadas em escala local na Nhecolândia. As águas desta região apresentam uma alcalinidade mais elevada que os teores em cálcio, e quando submetidas ao processo de evaporação evoluem dentro de uma via alcalina sódica (Barbiéro et al., 2002, 2004). Vários estudos descreveram as precipitações salinas e a neoformação de argilas que acompanham o processo de evaporação das águas: (1) da Mg-calcita, ou calcitas magnesianas, com aproximadamente $5 \%$ de Mg; (2) dos silicatos magnesianos tipo estevensita e saponita (Furquim et al., 2008, 2010a). Nessas condições em que a evaporação é acompanhada por precipitações de sais, a alcalinidade e o pH aumentam, e os teores em cálcio e magnésio diminuem; e (3) da Fe-ilita, ou ilita ferruginosa, que explicaria o controle do potássio em solução (Furquim et al., 2010b).

A dispersão da nuvem de pontos de $\mathrm{Cl}^{-}$e $\mathrm{SO}_{4}{ }^{2-}$ nos diagramas de concentração pode ser atribuída às transformações pedológicos locais (Barbiéro et al., 2008; Rezende Filho, 2011), mas também a processos redox, ou ainda, a uma poluição decorrente da fertilização dos solos nos planaltos (Rezende Filho, 2011). 
Em síntese, a concentração das águas é acompanhada de uma elevação do $\mathrm{pH}$ que pode, rapidamente, alcançar valores próximos de 10. A boa correlação entre $\log _{10}(\mathrm{CE})$ e $\mathrm{pH}$ indicam que as águas evoluem dentro de um quadro químico único, expresso pela via alcalina sódica, atualmente bem conhecido.

\subsection{Alcances baixos e distribuição bimodal da variável $\log _{10}(C E)$.}

A análise geoestatística revelou valores de alcance muito baixos, inferiores a 200m. Esta distância, a partir da qual não há mais independência da variável $\log _{10}$ (CE), destaca que os processos responsáveis pela variabilidade química das águas agem localmente, ou seja, entre lagoas vizinhas. Estes resultados justificam um estudo local, que será apresentado no próximo capítulo.

A distribuição bimodal do $\log _{10}(C E)$ das águas dessa porção sul da Nhecolândia comporta informações adicionais. Esse processo, com ação local, também age de forma dicotômica, pois favorece o aparecimento seja de águas diluídas com pH neutro a ligeiramente ácido, seja de águas concentradas e alcalinas com pH elevado.

Outros pontos foram ressaltados neste capítulo: (i) que o processo parece agir na proximidade imediata das lagoas, e (ii) que ele produz efeitos de limiares nas características físico-químicas das águas.

No próximo capítulo, será apresentado o estudo de 4 salinas e seus entornos imediatos, a fim verificar os pontos aqui levantados. 
CAPÍTULO III

MORFOLOGIA DE SALINAS NA NHECOLÂNDIA 
O capítulo anterior apresentou o estudo realizado em escala regional, que destacou ampla gama de valores de condutividade elétrica das águas superficiais da Nhecolândia, e o caráter local dos processos a eles ligados. Isto coloca em pauta os materiais de sustentação física das salinas, e suas morfologias, ou seja, a própria cobertura pedológica ligada às salinas. O objetivo deste capítulo é pesquisar no entorno imediato das lagoas salinas, em um raio de aproximadamente $200 \mathrm{~m}$, os fatores responsáveis pela variabilidade observada da CE das águas. Para isto, utilizou-se métodos diretos de observação da cobertura pedológica, e métodos indiretos por indução eletromagnética, complementados por uma caracterização dos constituintes do solo em laboratório.

\section{MATERIAIS E MÉTODOS}

\section{1. Áreas de estudo}

Para realizar este estudo foram selecionadas quatro salinas. Os critérios que guiaram essa seleção foram: (1) ambientes mais preservados ou pouco remanejados, principalmente por desmatamento nas proximidades imediatas das salinas; (2) condutividade elétrica da água acima de $2000 \mu \mathrm{S} . \mathrm{cm}^{-1}$; (3) grau de salinidade representativa da gama de salinidade regional, que varia de 2000 à 70000 $\mu S . \mathrm{cm}^{-1} ;$ (4) facilidade de acesso, e proximidade das salinas umas das outras, para otimizar os trabalhos de campo.

$\mathrm{Na}$ Figura 23 são apresentadas as quatro salinas localizadas na Fazenda Centenário, que preencheram esses critérios. As coordenadas e a condutividade elétrica das águas, medidas no campo são apresentadas na Tabela 7. 
Tabela 7. Localização e condutividade elétrica das 4 salinas selecionadas.

\begin{tabular}{c|cc|cc}
\hline Salinas & \multicolumn{2}{c|}{ Coordenadas UTM } & \multicolumn{2}{c}{ CE $\mu$ S.cm ${ }^{-1}$} \\
& $X^{-1}$ & Y & Set/09 & Mai /10 \\
\hline Verde & 598915 & 7846624 & 1980 & 2395 \\
Preta & 591165 & 7849306 & 4750 & 1128 \\
Grande & 591394 & 7849336 & - & 3080 \\
60 mil & 590459 & 7847808 & 60400 & - \\
\hline
\end{tabular}

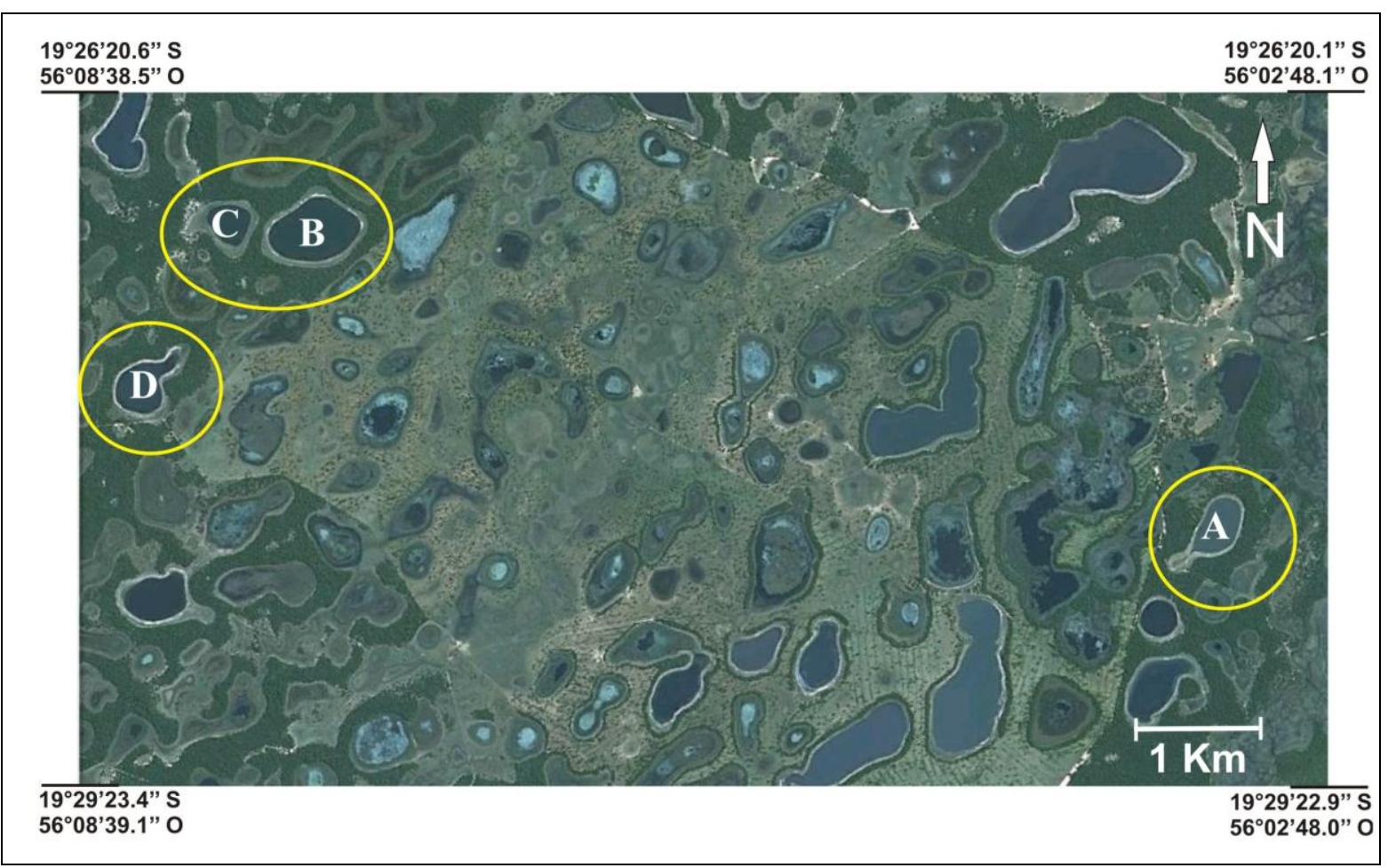

Figura 23. Localização das salinas para estudos em escala local: (A) Salina Verde, (B) Salina Grande, (C) Salina Preta e (D) Salina 60 Mil (Fonte: Imagem Google Earth/2012).

\subsubsection{Salina Verde}

A Salina Verde $\left(0.15 \mathrm{Km}^{2}\right)$ se localiza nas Coordenadas UTM $598915 \mathrm{~W}$ 7846624 S, Zona 21. A vegetação da cordilheira de entorno apresenta-se bem preservada, e a salina é cercada por uma praia de areia branca bem desenvolvida. A forma é ligeiramente arredondada com um alongamento para sudoeste em forma de divertículo com direção SW-NE. O fundo da lagoa é composto de espessa camada escura de matéria orgânica, e a cor da água é verde. Esta coloração se dá pela presença de grande quantidade de algas, principalmente cianobactérias (Santos et 
al., 2011). Durante o período de cheia, o nível da água da salina sobe e se expande até o divertículo SW-SE, reforçando sua forma alongada. Depois, quando inicia o período de seca há uma retração da água, e o divertículo passa a funcionar, de maneira fugaz, como uma pequena salina independente. Assim, durante um curto período de tempo prevalecem duas salinas nessa área. A Salina Verde tende a permanecer com água por muito mais tempo durante a estação seca, e chega a secar apenas se esta for muito prolongada. Em seu nível mais baixo são frequentes os borbulhamentos de gases na água, que adquire um aspecto mais viscoso, e cor verde mais escura (Foto 2). A CE da água, medida em setembro de 2009 e maio de 2010, variou de 1980 a $2395 \mu$ S. $\mathrm{cm}^{-1}$.
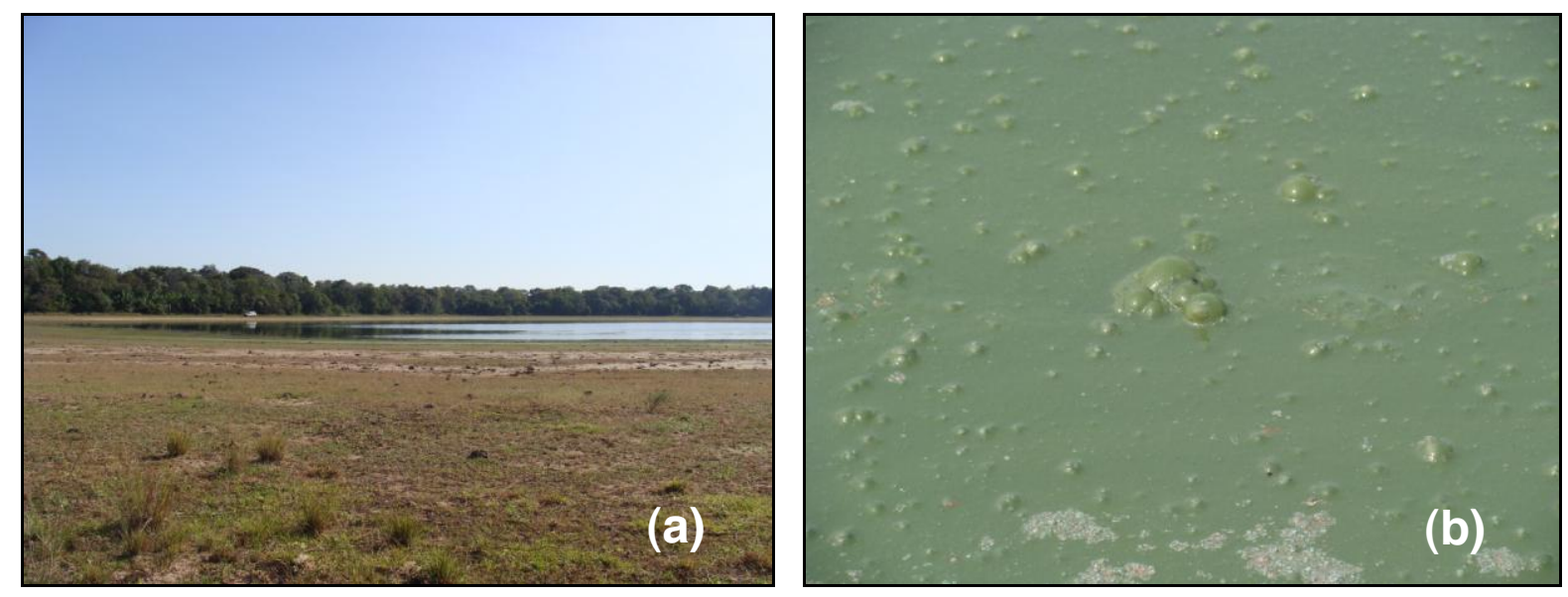

Foto 2. Salina Verde nos períodos: (a) úmido e (b) seco com borbulhamentos.

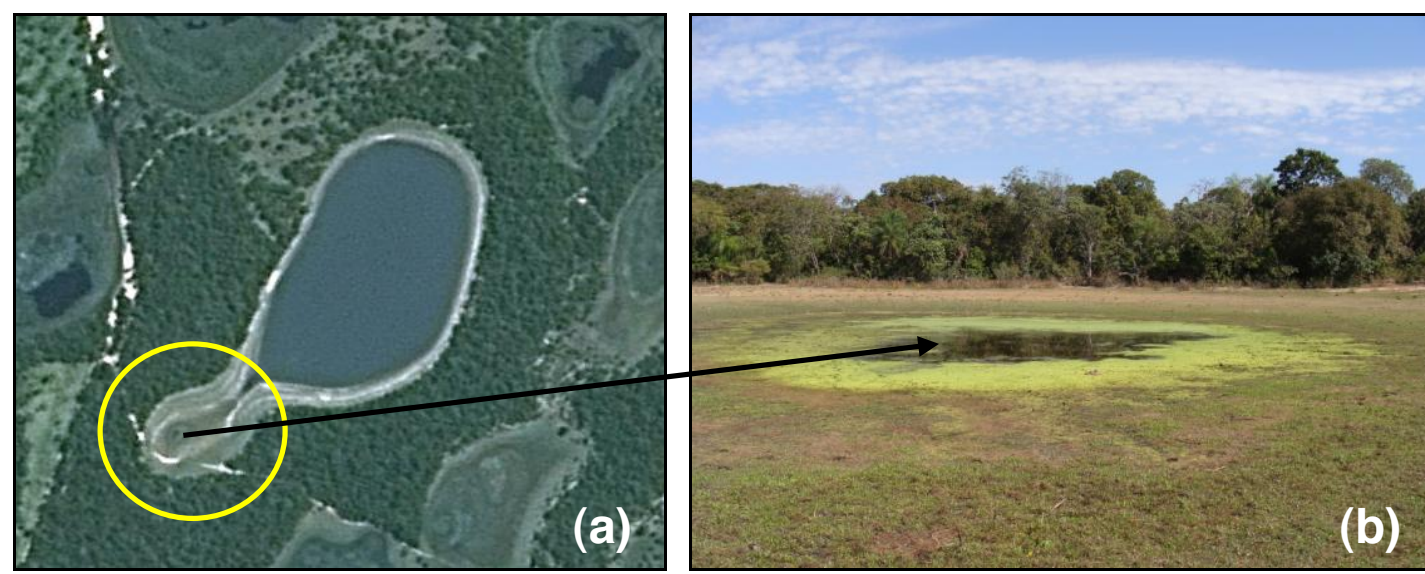

Figura 24. (a) Salina Verde com destaque do alongamento em forma de divertículo (Fonte: Google Earth), e (b) divertículo quando funciona como pequena salina independente (Foto do autor, 2011). 


\subsubsection{Salina Preta}

A Salina Preta $\left(0.09 \mathrm{Km}^{2}\right)$ se localiza nas coordenadas UTM $591165 \mathrm{~W}$ 7849306 S, Zona 21 (Foto 3). As cordilheiras sustentam a vegetação de seu entorno, que também é bem preservada. Esta salina é arredondada, e tem uma praia cuja forma não é arredondada. Um lado da praia é retilíneo e estreito enquanto o lado oposto é mais largo, em forma de língua, com contorno irregular. A praia de areia branca no entorno imediato da salina é pouco extensa e irregular, pois a maior parte se encontra recoberta por gramíneas e arbustos. O fundo é basicamente arenoso, coberto por uma camada de alguns centímetros de sedimento orgânico escuro, e água de cor marrom escuro, sem algas. Na estação úmida, o grau de salinidade da água não é considerado muito alto se comparado ao das demais, e aumenta na estação seca. Nos anos 2009 e 2010, a CE da água variou de 1128 a $4750 \mu \mathrm{S} . \mathrm{cm}^{-1}$. Essa salina é mais profunda que as outras, pois normalmente atinge mais de $2,5 \mathrm{~m}$ na parte central. Ela não seca no período de estiagem, quando se observa apenas uma ligeira diminuição de $0,5 \mathrm{~m}$ no nível da água. Ela está muito próxima da Salina Grande, da qual é separada por uma cordilheira, a uma distância aproximada de $100 \mathrm{~m}$ de uma praia para outra (Figura 23).
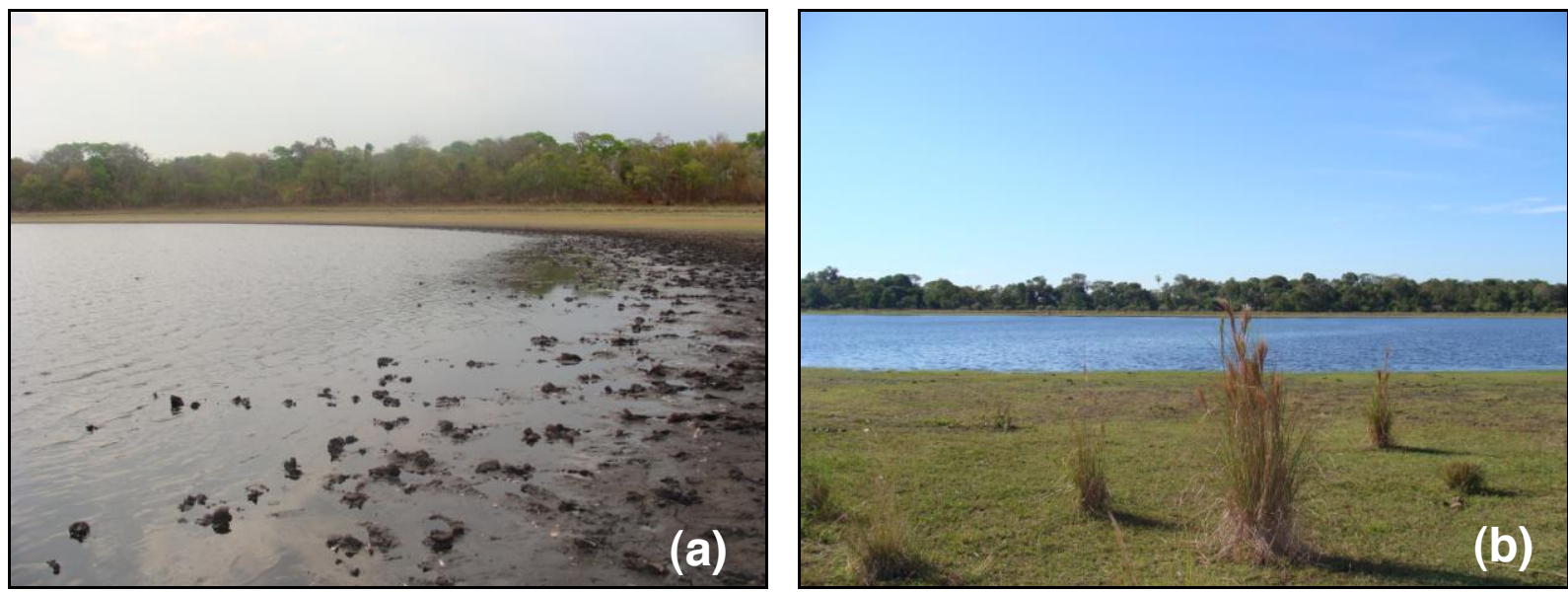

Foto 3. Salina Preta nos períodos: (a) seco e (b) úmido. 


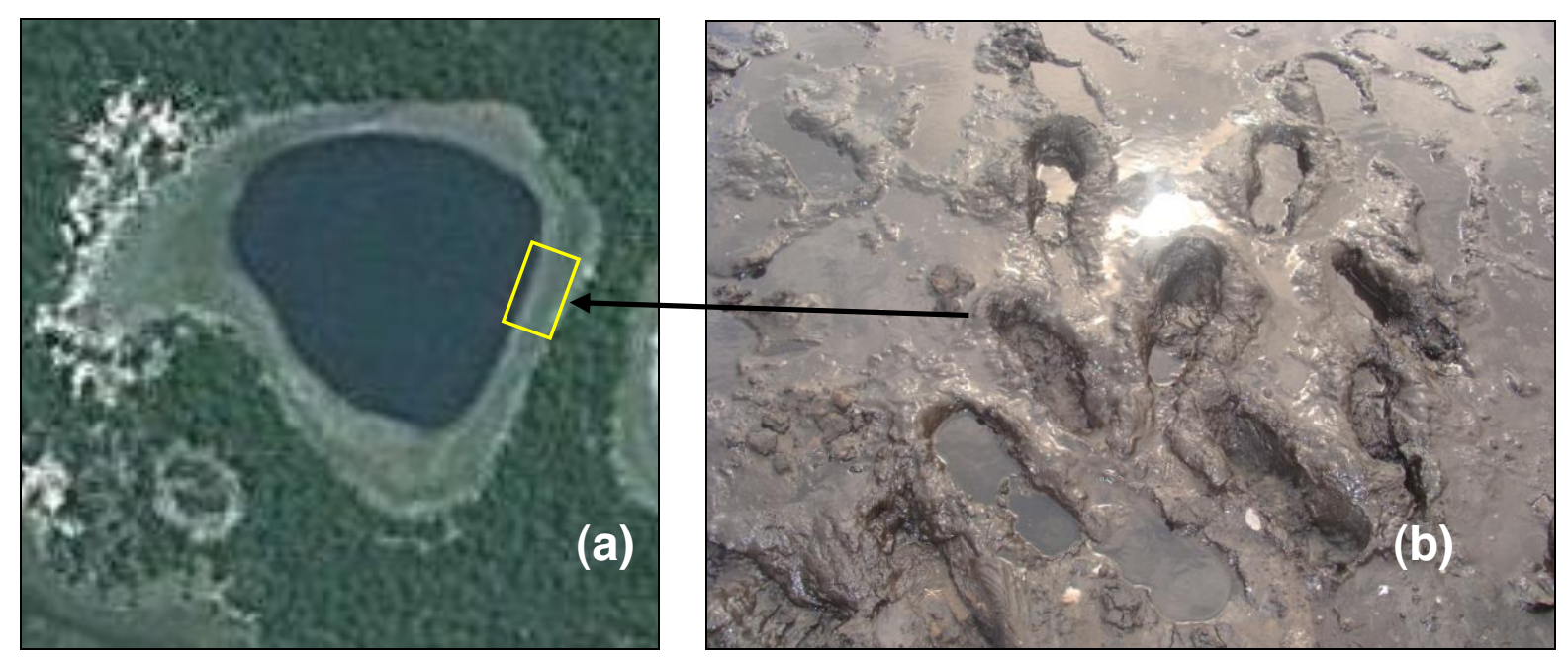

Figura 25. (a) Salina Preta (b) sedimento escuro do fundo da salina com alguns centímetros de espessura, melhor observado no período de estiagem.

\subsubsection{Salina Grande}

A Salina Grande $\left(0.32 \mathrm{Km}^{2}\right)$ se localiza nas coordenadas UTM $591394 \mathrm{~W}$ 7849336 S, Zona 21. Observa-se na Figura 23 e Foto 4 que a vegetação da cordilheira em seu entorno é bem preservada, e que a cordilheira a isola das águas das vazantes. A forma desta salina é ligeiramente alongada a arredondada, com uma pequena reentrância para norte, e uma praia extensa de areia branca parcialmente coberta por gramíneas. O seu fundo é composto por uma camada pouco espessa de sedimento cinza esverdeado orgânico, sobreposto a um material arenoso. A água é verde e contém algas. Essa salina secou totalmente no período de estiagem de 2009, e mesmo no período úmido de 2010 o nível da água não subiu totalmente, permanecendo baixo, com salinidade elevada e CE da água de 3080 $\mu \mathrm{S} . \mathrm{cm}^{-1}$. 


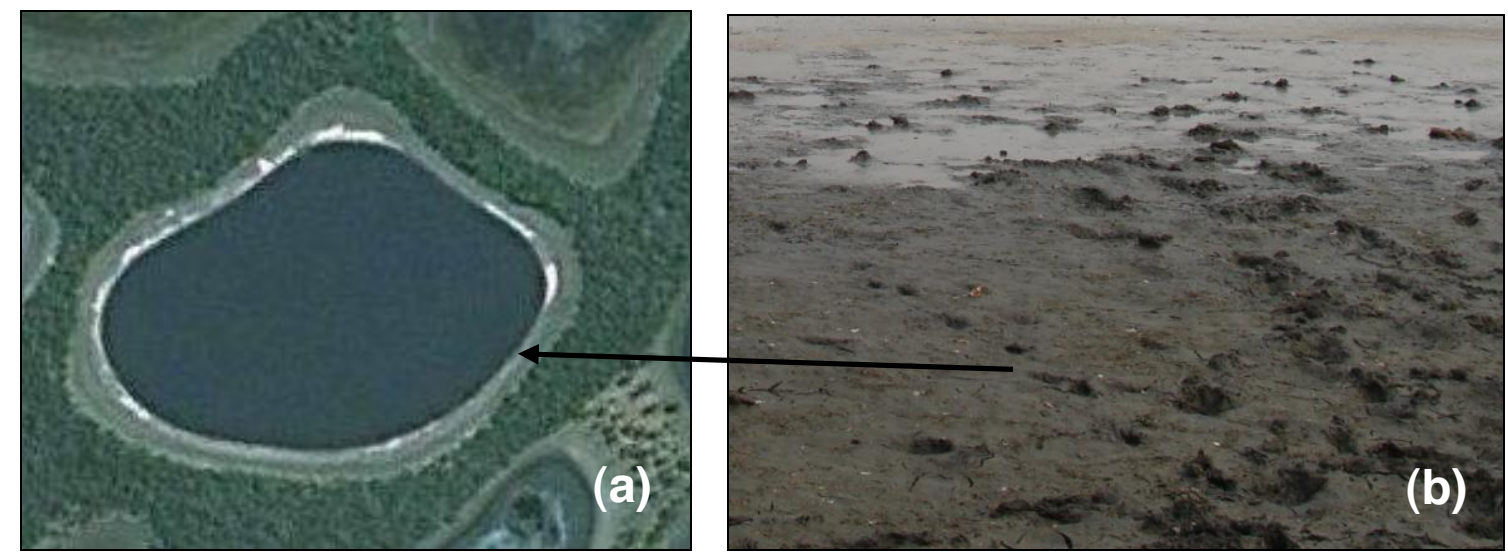

Figura 26. (a) Salina Grande e (b) sedimento orgânico do fundo da salina.
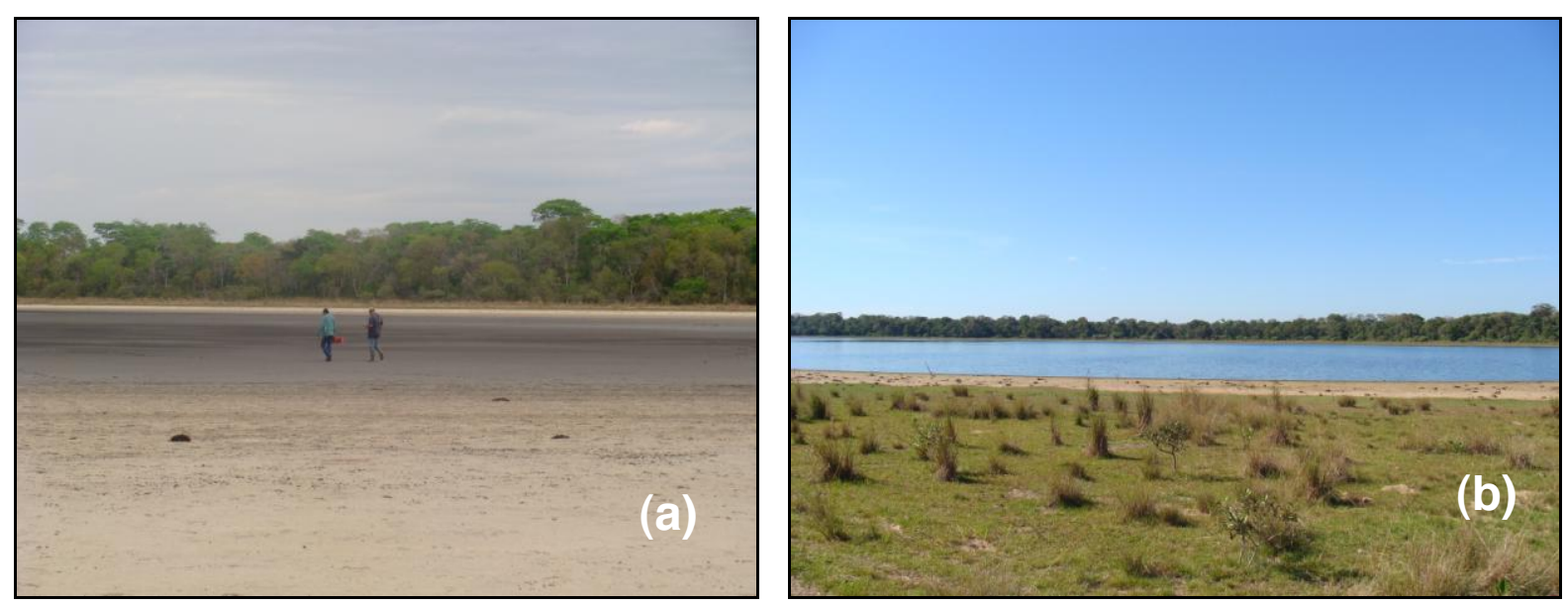

Foto 4. Salina Grande nos períodos: (a) seco e (b) úmido.

\subsubsection{Salina 60 Mil}

A Salina 60 Mil $\left(0.14 \mathrm{Km}^{2}\right)$ se localiza nas coordenadas UTM $590459 \mathrm{~W}$ e 7847808 S, Zona 21. A vegetação de entorno nas cordilheiras é bem preservada. A forma é arredondada, com um alongamento pronunciado para nordeste, e direção SW-NE. Apresenta extensa praia de areia branca, com faixa restrita de gramínea. $\mathrm{O}$ fundo desta salina é composto de um material arenoso muito endurecido, cimentado como laje, recoberto por sedimentos escuros orgânicos com aproximadamente 20 $\mathrm{cm}$ de espessura. O limite entre o material orgânico e a laje é abrupto. A água é esverdeada clara, com algas. Essa salina apresentou valores de salinidade extremamente altos, e em setembro de 2009 a CE da água foi de $60400 \mu \mathrm{S} . \mathrm{cm}^{-1}$. O 
nível de água abaixa muito durante o período de estiagem, quando quase chega a secar (Foto 5). A cheia de 2010 alagou o entorno dessa salina, que permaneceu sem acesso até maio de 2010.
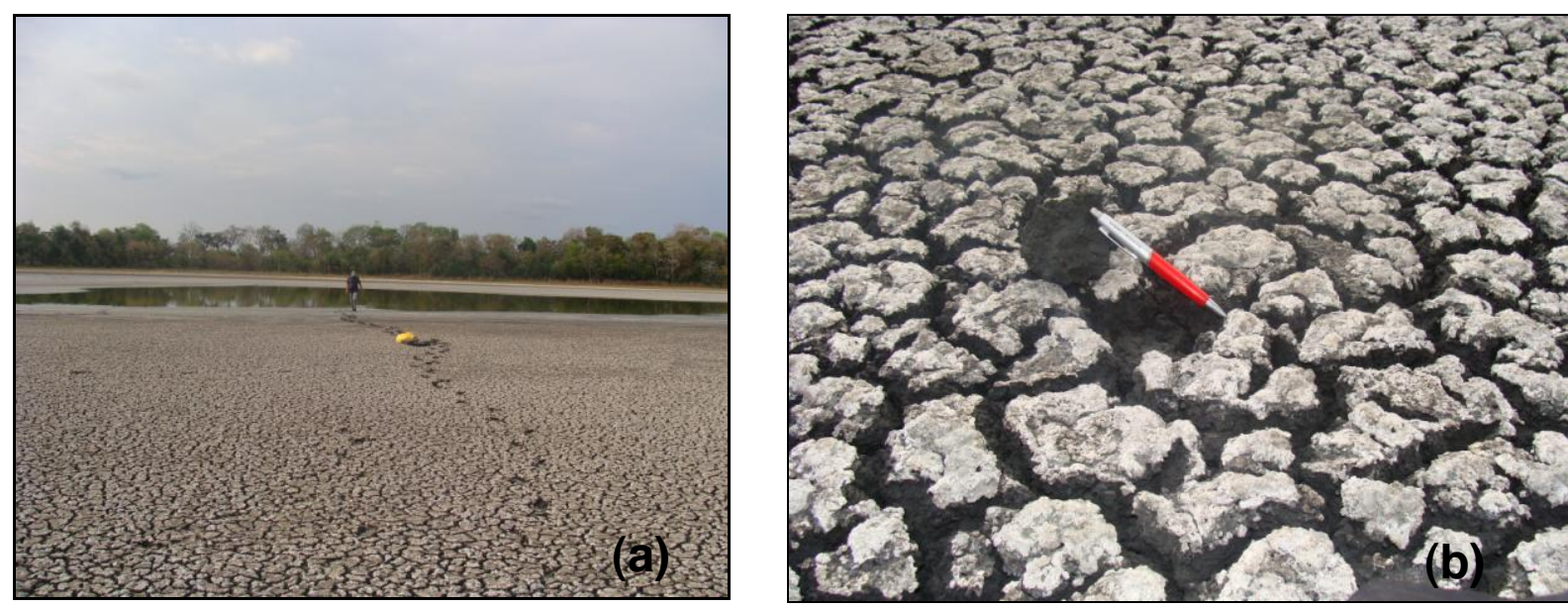

Foto 5. (a) Salina 60 Mil no período seco de setembro/2009 e (b) sedimento orgânico do fundo da salina recoberto por florescência de sais (em branco).

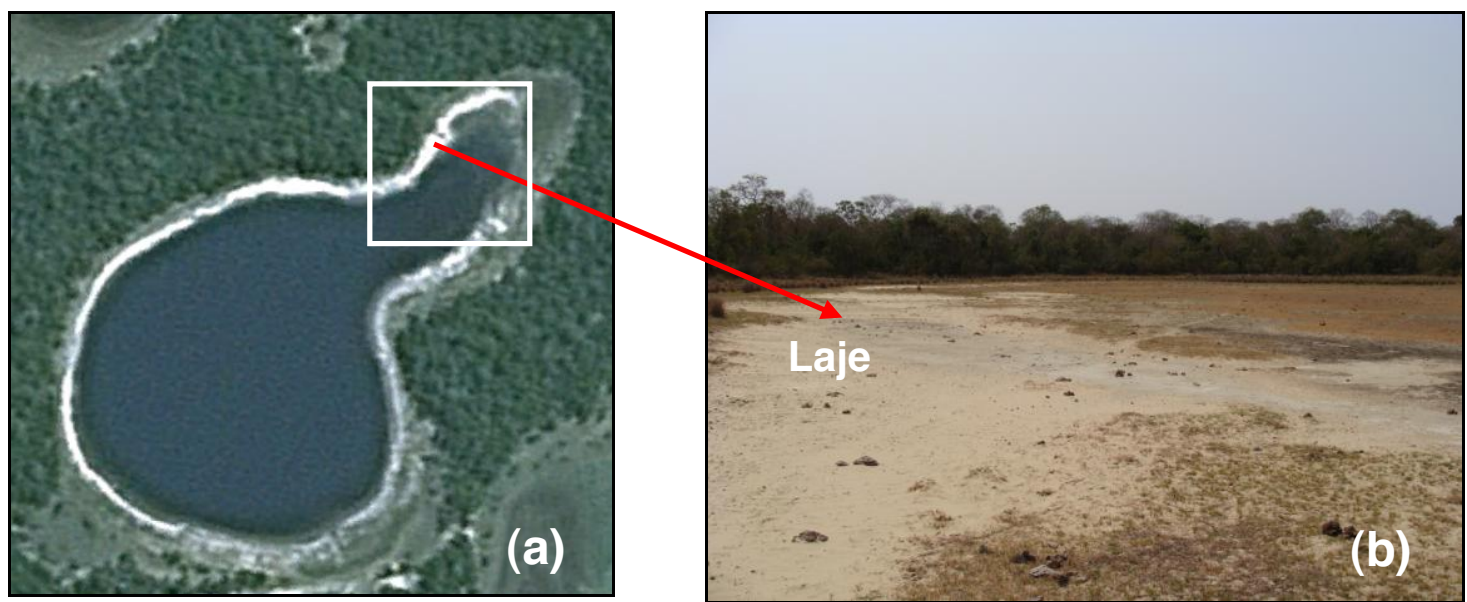

Figura 27. Localização da laje (a) e (b) foto da laje que aflora em superfície.
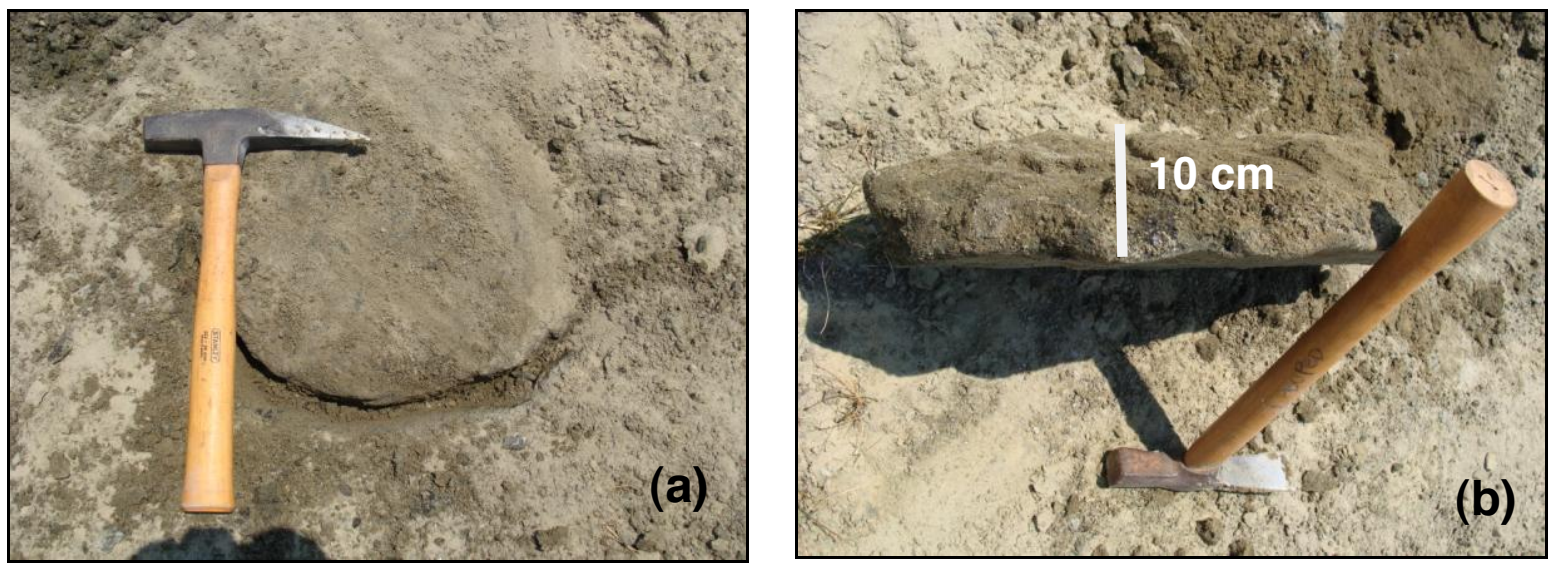

Foto 6. Coleta de amostras da laje (a) e (b). 


\subsection{Mapeamento por indução eletromagnética (EM38 e EM31)}

Pesquisas realizadas anteriormente no Pantanal da Nhecolândia mostram que a topografia pouco marcada dessa região dificulta o posicionamento de sequências, para observações da cobertura pedológica. Além disto, que o tipo de vegetação não segue, necessariamente, a organização dos solos. Nesse caso, topografia e vegetação não podem ser referências para posicionar pontos de observações da cobertura pedológica. Por isto, sugerem a aplicação de métodos geofísicos não destrutivos de observações indiretas do solo por indução eletromagnética, que é uma técnica rápida de medida da condutividade elétrica aparente (CEa) dos solos (Barbiéro et al., 2002; Rezende Filho, 2006, Barbiéro et al., 2008).

\subsubsection{Equipamentos e funcionamento}

A condutividade elétrica é definida como a habilidade de um material em conduzir corrente elétrica. Isto é uma propriedade intrínseca do solo que depende, principalmente, do seu teor de argila, e de seus graus de umidade e de salinidade (McNeill, 1980). O grau de cimentação dos horizontes, produzido por pontes de natureza variável (sílica, calcário, argila) entre os grãos, também interfere na capacidade do material de conduzir corrente elétrica.

Os métodos eletromagnéticos indutivos se baseiam na propagação de ondas eletromagnéticas de baixa frequência $(<1 \mathrm{MHz})$ : uma corrente primária se propaga na bobina transmissora do aparelho e cria um campo magnético primário. Este campo afeta o campo magnético do meio condutor, no caso o solo, e induz o aparecimento de correntes elétricas secundárias, que ao se propagarem pelo condutor produzem um campo magnético secundário. Por sua vez, este campo 
propaga a corrente elétrica secundária do condutor para a bobina receptora do aparelho. A razão da corrente elétrica secundária pela primária é linearmente proporcional à condutividade do terreno. Essa informação expressa a condutividade elétrica do solo, que é lida diretamente no equipamento em miliSiemens por metro $(\mathrm{mS} / \mathrm{m})$

Para este estudo utilizaram-se dois condutivímetros eletromagnéticos, o EM31-MK2 e o EM38-MK2 (Geonics). Trata-se de dispositivos portáteis com aquisição rápida de medidas, cujo tempo depende principalmente da velocidade de locomoção do observador de um ponto a outro de medida. Estes aparelhos são acoplados a um GPS (modelo Holux m241) a fim de georeferenciar as medidas.

Os aparelhos EM31-MK2 e o EM38-MK2 medem a condutividade elétrica aparente, que é a média ponderada de condutividade em função da profundidade (McNeill, 1980; McNeill e Bosnar, 1999). Os aparelhos podem ser utilizados em duas posições em função da orientação das bobinas: nas posições horizontal (DMH) Dipolo Magnético Horizontal, e vertical (DMV) Dipolo Magnético Vertical. Dependendo da posição do dipolo, muda-se a sensibilidade da resposta dos aparelhos, o que geralmente possibilita discriminar a profundidade das camadas mais condutoras.

As diferenças entre esses dois aparelhos são, de um lado, a distância entre as bobinas transmissoras e receptoras, e de outro, a frequência de indução. Estas diferenças conferem aos equipamentos diferentes profundidades de investigação. A Figura 28 apresenta as curvas de repostas dos aparelhos em função da profundidade, e a Foto 7 mostra o procedimento de aquisição dos dados de CEa do solo com os aparelhos no campo. 


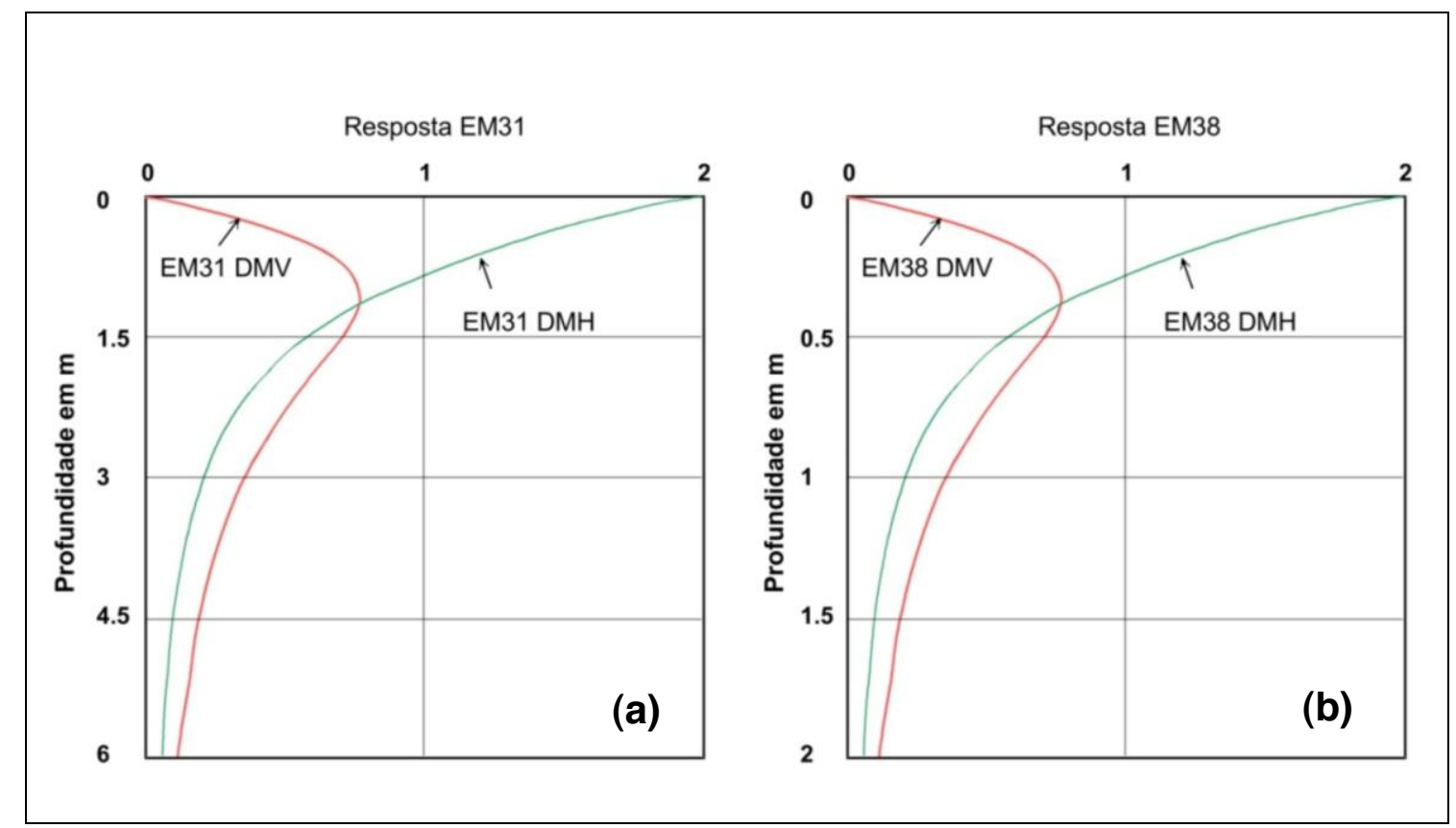

Figura 28. Curvas de respostas do (a) EM31 e (b) EM38, em função da profundidade efetiva de investigação.
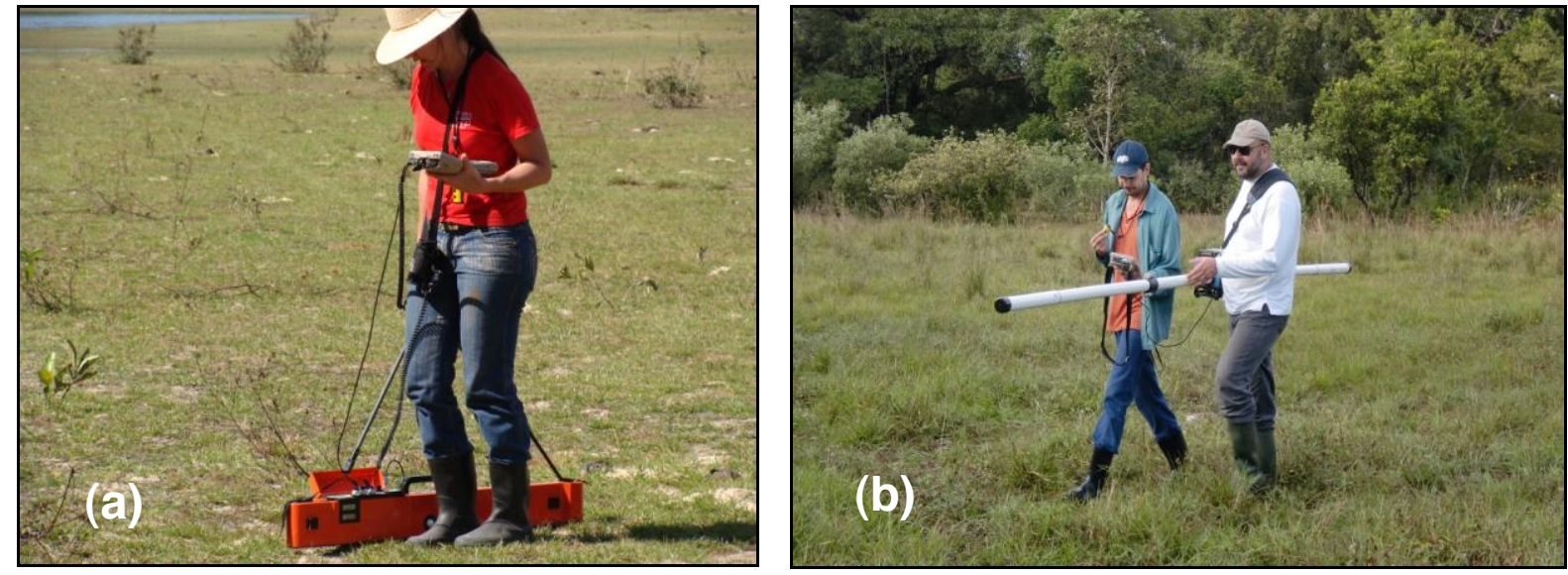

Foto 7. Aquisição de dados de CEa do solo com os aparelhos (a) EM38-MK2 e (b) EM31-MK2.

O EM38-MK2 possui $1 \mathrm{~m}$ de espaçamento entre bobinas, e frequência de indução de $14.6 \mathrm{kHz}$. A posição em dipolo horizontal (DMH) é mais sensível para os horizontes superficiais, e cerca de $75 \%$ do sinal da condutividade elétrica aparente vem da profundidade de investigação de 0 a 0,75m (Figura 28 (b), curva verde). Em posição de dipolo vertical (DMV), cerca de $75 \%$ do sinal da condutividade elétrica aparente vem da profundidade de investigação de 0 a 1,5m, com baixa sensibilidade para os horizontes superficiais (Figura 28 (b), curva vermelha). A leitura da 
condutividade aparente é imediata, após posicionar o aparelho na superfície do solo ele demora aproximadamente um segundo para estabilizar, e em seguida é dada a medida.

O EM31-MK2 possui uma distância entre bobinas de 3,66 metros, e uma frequência de indução de $9,8 \mathrm{kHz}$, o que aumenta a profundidade efetiva de investigação para 6 metros de profundidade (Figura 28 (a)). Para efetuar as medidas, o aparelho é mantido a aproximadamente $1 \mathrm{~m}$ da superfície do solo, e a medida é registrada manual, ou automaticamente, em função da programação definida (cada segundo, cada 5 segundos, etc.), e da velocidade de locomoção do operador.

Numerosos trabalhos utilizando o EM38 foram divulgados na literatura científica. A maior parte deles é dirigida à agricultura e ao mapeamento da salinidade dos solos (Diaz e Herrero, 1992; Bennett e George, 1995; Barbiéro et al., 2001; Sudduth et al., 2001; Lesch e Corwin, 2005). Recentemente, ele foi aplicado ao estudo da variabilidade química das unidades de paisagem da Nhecolândia (Rezende Filho, 2006, Barbiéro et al., 2008). Ao contrário, são poucos os trabalhos feitos com o EM31, apesar de sua aplicação poder abranger diversas áreas de estudos (Sheets e Hendrickx, 1995; Hauck et al., 2004; Barbiéro et al., 2007).

\subsubsection{Procedimentos de aquisição dos dados}

Os procedimentos de aquisição de dados dependem do tipo de aparelho. No caso do EM38-MK2, a aquisição dos dados é feita manualmente pelo operador. O aparelho é conectado a um microcomputador (Allegro DAS70-CX), no qual se faz a

programação da aquisição e gestão dos dados com o programa DAT38MK2 (Figura 29). Ao microcomputador também se conecta, via porta Bluetooth, um GPS (modelo 
Holux m241). O conjunto de dados registrados ao mesmo tempo é: a CEa (condutividade elétrica aparente), o tempo em h, min., seg., e a posição georeferenciada em coordenada UTM (X, Y).

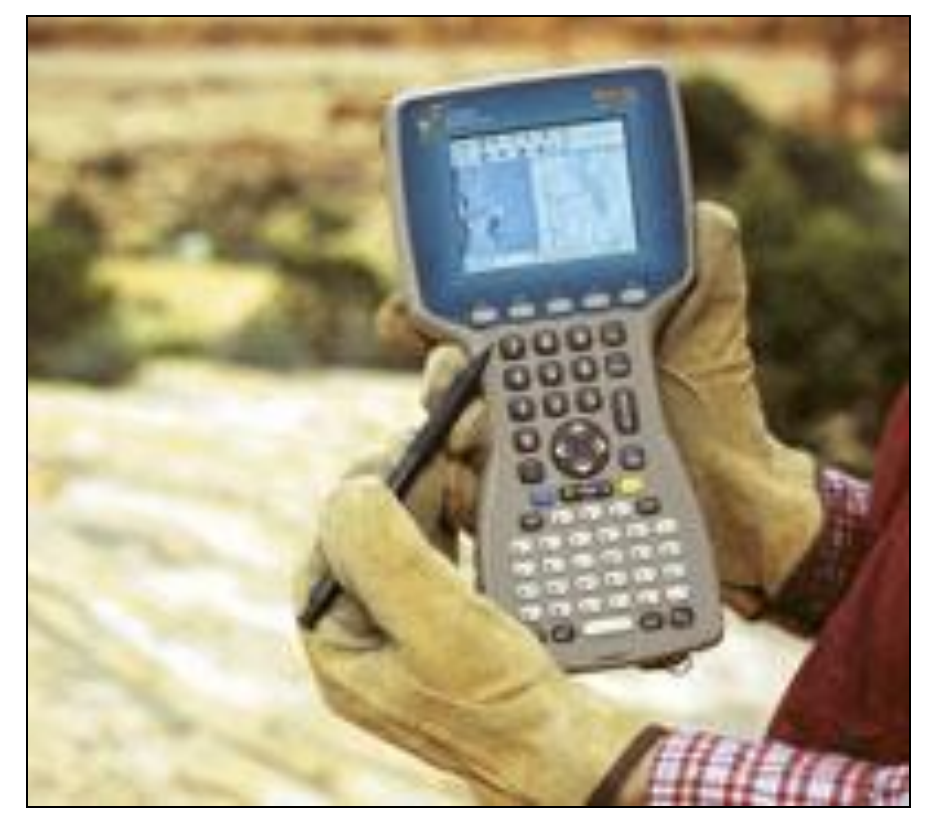

Figura 29. Micro-computador (Allegro DAS70-CX).

No caso do EM31-MK2, o programa DAT31MK2 não permite uma conexão via Bluetooth. A aquisição de dados é realizada de maneira independente com o microcomputador, modelo Allegro DAS70-CX, e com o GPS após sincronização dos relógios de cada aparelho. A correspondência entre o valor de CEa e a posição do ponto de medição é realizada posteriormente, ajustando-se o tempo em cada arquivo onde os dados foram armazenados.

Durante a prospecção, tentou-se manter uma distância de $10 \mathrm{~m}$ entre os pontos de medidas, e também entre as linhas de prospecção. Este procedimento foi adotado para as todas salinas.

\subsubsection{Tratamento dos dados}

Os dados brutos de Condutividade Elétrica Aparente (CEa) foram tratados pelos mesmos métodos estatísticos e geoestatísticos descritos no capítulo anterior, a 
saber: análise da distribuição estatística, análise do variograma experimental, ajustamento de um modelo pelo método dos mínimos quadrados, krigeagem e representação cartográfica.

\subsection{Morfologia dos solos e caracterização físico-química dos constituintes e das águas}

As observações diretas dos solos em trincheiras e tradagens foram posicionadas de maneira a recobrir as principais faixas de variabilidade da condutividade elétrica aparente (CEa) dos solos. Essas observações foram guiadas pelo método da análise estrutural da cobertura pedológica (Boulet et al., 1982).

As análises granulométricas foram realizadas por pipetagem e peneiramento após remoção da matéria orgânica por tratamento $\mathrm{H}_{2} \mathrm{O}_{2}$ a uma temperatura de $50^{\circ} \mathrm{C}$, segundo métodos utilizados no Laboratório de Sedimentologia (IG, USP), Foto 8.
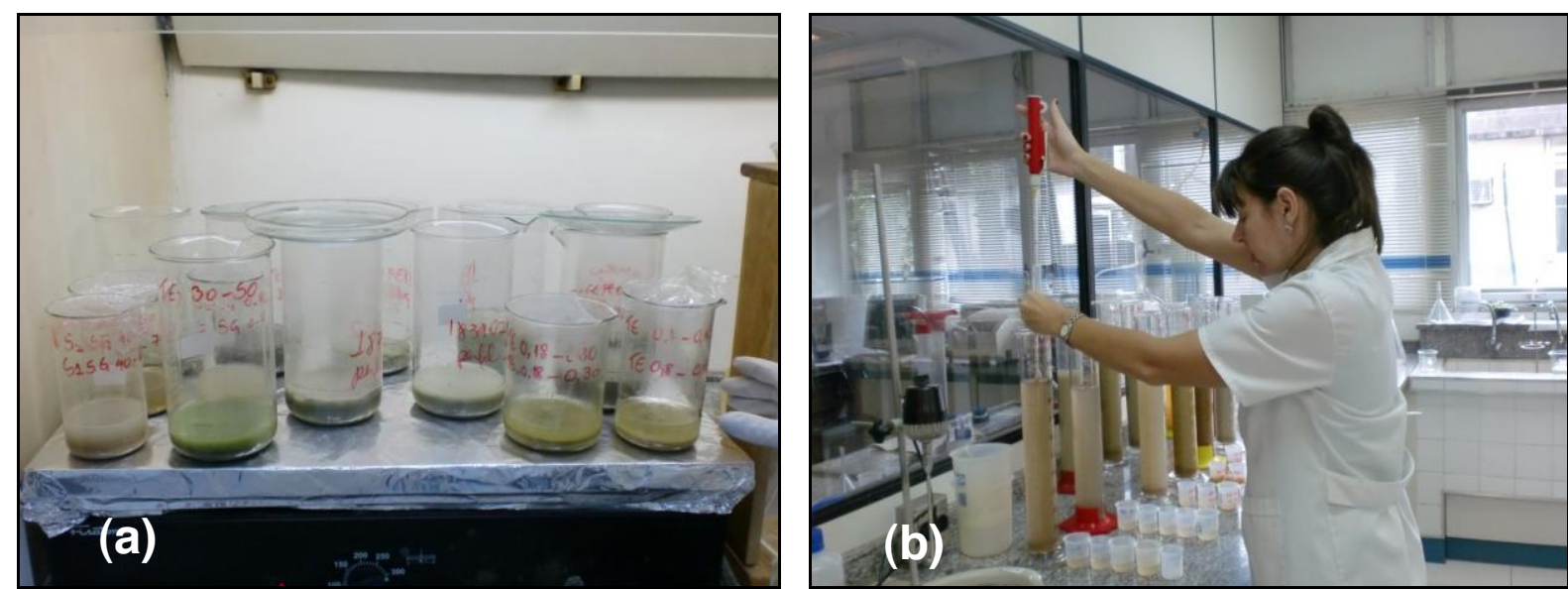

Foto 8. Extração da matéria orgânica (a) e pipetagem (b).

A mineralogia da fração argila foi identificada por Difração de Raios X sobre 4 lâminas orientadas, três dos horizontes profundos areno-argilosos e uma do contato entre estes e os horizontes arenosos superficiais. Três tipos de tratamentos foram utilizados: (1) condição natural; (2) saturação em etileno glicol, e (3) 
aquecimento ao forno a $500^{\circ} \mathrm{C}$ durante 4 horas. As análises das lâminas foram realizadas no Laboratório de Difração de Raios X (IG, USP), com o aparelho Brucker Siemens, modelo D5000, operando em $40 \mathrm{Kw}$ e $40 \mathrm{~m} \AA$ (miliamper) com tubo de cobre Ka.

As características físico-químicas das águas e dos sedimentos foram medidas in situ conforme descrito anteriormente no Capítulo II, dentro das salinas a aproximadamente 20 metros das bordas. Os materiais utilizados foram um pHmêtro (modelo $\mathrm{HI}$ 98140), um condutivímetro que também mede a temperatura em ${ }^{\circ} \mathrm{C}$ (modelo HI 9838), um pHmêtro com medidor de redox (modelo HI 98150), um medidor de turbidez (modelo HI 98703), e um medidor de oxigênio dissolvido (modelo $\mathrm{HI}$ 9148), todos do HANNA Instruments (Foto 9). As medidas foram realizadas no período seco, dezembro e abril de 2009, 2010 e 2011, sendo que a de maio de 2010 ocorreu no período de transição do úmido para o seco.

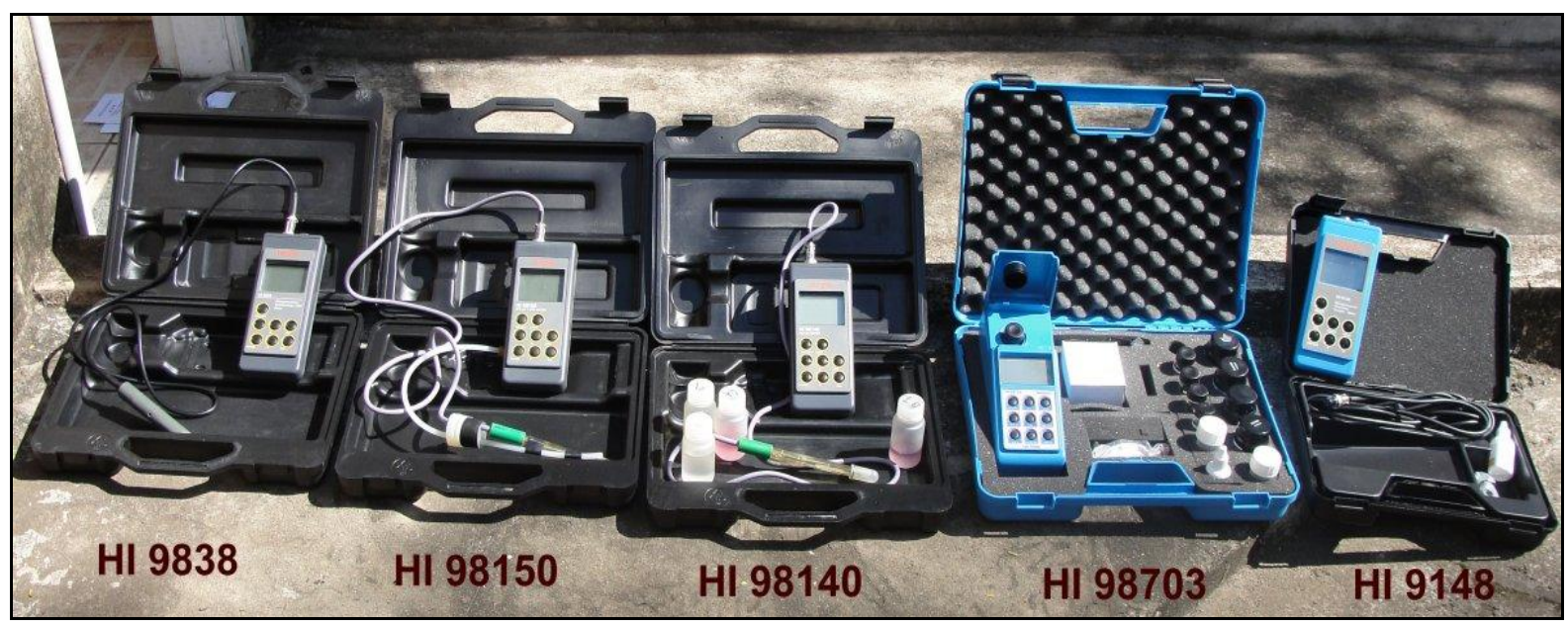

Foto 9. Da esquerda para direita, os aparelhos: Condutivímetro, Ehmêtro, pHmêtro, Turbidímetro e Oxímetro.

As medidas de $\mathrm{pH}$ e redox dos sedimentos são apresentados em termos de gama de valores mínimos e máximos de 10 medidas realizadas mantendo a sonda (eletrodo) durante 10 segundos no sedimento. 


\section{RESULTADOS}

\subsection{Características físico-químicas das águas e dos sedimentos das salinas.}

A Tabela 8 apresenta os resultados das medidas in situ da Condutividade Elétrica $\left(C E\right.$ em $\left.\mu S . \mathrm{cm}^{-1}\right)$, Temperatura $\left(C^{\circ}\right)$, Oxigênio Dissolvido (O.D\%) e Turbidez (NTU) da água e, pH e Redox (Eh em mv) da água e sedimento, realizadas nas 4 salinas.

Observa-se que, de um modo geral, no mesmo período do ano ocorre uma grande variabilidade da CE entre as águas das salinas. Em 2010, durante a estação seca (abril a setembro), por exemplo, há um aumento significativo da condutividade elétrica, cuja proporção é variável para cada salina: 8,1 vezes para a Salina Verde, 3,7 para a Salina Grande, e apenas 2,1 para a Preta.

Há também uma variabilidade expressiva em relação aos valores de $\mathrm{pH}$, embora a Salina Preta apresente valores relativamente estáveis se comparados com os resultados obtidos nas demais salinas. Enquanto na Salina Preta o $\mathrm{pH}$ varia de 8.5 a 9.47 , nas demais salinas os valores variam de 7.3 a 10.26 .

Tal como, as diferenças de valores observadas nos parâmetros $\mathrm{CE}$ e pH, os dados dos parâmetros (Temperatura, O.D, Turbidez e Redox) revelam igualmente essa variabilidade.

Estes resultados serão discutidos detalhadamente no decorrer deste Capítulo. 
Tabela 8. Características físico-químicas das salinas nos períodos secos, de abril a setembro (2009, 2010 e 2011) e, úmido de outubro a março (2010).

\begin{tabular}{|c|c|c|c|c|c|c|c|c|c|c|c|c|}
\hline & \multicolumn{3}{|c|}{ Setembro/2009 } & \multicolumn{5}{|c|}{ Maio/ 2010} & \multirow[b]{2}{*}{ Verde } & \multicolumn{2}{|c|}{ Setembro/2010 } & \multirow[b]{2}{*}{$60 \mathrm{Mil}$} \\
\hline & Verde & Grande & Preta & $60 \mathrm{Mil}$ & Verde & Grande & Preta & $60 \mathrm{Mil}$ & & Grande & Preta & \\
\hline $\mathrm{CE}\left(\mu \mathrm{S} . \mathrm{cm}^{-1}\right)$ & 1980 & - & 4750 & 60400 & 2395 & 3080 & 1128 & - & 19473 & 11470 & 2440 & 7150 \\
\hline $\mathrm{pH}$ & 7,3 & - & 8,82 & 7,9 & 10.08 & 9,47 & 8,88 & - & 9,37 & 9,82 & 9,03 & 9,25 \\
\hline Temp $\mathrm{C}^{\circ}$ & 25,4 & - & 29,2 & 26,3 & 25.4 & 25.6 & 25.4 & - & 34 & 27.3 & 30.6 & 34.5 \\
\hline Eh (Sed.) mV & - & - & - & - & $-178 /+16$ & $-9 /+38$ & $-184 /+137$ & - & $-200 /-243$ & $-100 /-139$ & $-16 /+140$ & $-180 /-201$ \\
\hline Eh (água) mV & - & - & - & - & +136 & +381 & +266 & - & +72 & -19 & +384 & -134 \\
\hline $\mathrm{pH}$ (sed) & - & - & - & 9 & $9,60 / 9,73$ & $9,36 / 9,38$ & $9,86 / 9,94$ & - & - & - & - & - \\
\hline \multirow[t]{3}{*}{ Turbidez (NTU) } & - & - & - & - & - & - & - & - & $>1000$ & $>1000$ & $>1000$ & $>1000$ \\
\hline & & \multicolumn{2}{|c|}{ Outubro/2010 } & & & \multicolumn{2}{|c|}{ Julho/2011 } & & & \multicolumn{2}{|c|}{ Outubro/2011 } & \\
\hline & Verde & Grande & Preta & $60 \mathrm{Mil}$ & Verde & Grande & Preta & $60 \mathrm{Mil}$ & Verde & Grande & Preta & $60 \mathrm{Mil}$ \\
\hline $\mathrm{CE}\left(\mu \mathrm{S} . \mathrm{cm}^{-1}\right)$ & 1330 & 6530 & 2005 & 1755 & 1400 & 2250 & 570 & 659 & 1858 & 3740 & 740 & 1270 \\
\hline $\mathrm{pH}$ & 9.78 & 9.8 & 9.09 & 9.55 & 10,25 & 9,87 & 8,50 & 9,47 & 10,26 & 9,77 & 8,97 & 9.98 \\
\hline Temp $\mathrm{C}^{\circ}$ & 25 & 28.7 & 28.1 & 27.6 & 33,9 & 28,5 & 25,4 & 24,2 & 31,8 & 30,8 & 30,7 & 36,1 \\
\hline Eh (Sed.) mV & $-321 /-239$ & $-379 /-324$ & $+86 /+106$ & $-174 /-164$ & $-330 /-240$ & $-190 /+114$ & $-40 /+57$ & $-155 /+131$ & - & -244 & -200 & -183 \\
\hline Eh (água) mV & +174 & +276 & +236 & +176 & +216 & +211 & +200 & +332 & +285 & +251 & +319 & +262 \\
\hline O.D (\%) & 149 & 12 & 72 & 105 & 385,7 & 247,7 & 67,9 & 80,1 & 190 & 57,5 & 53 & 56,4 \\
\hline Turbidez (NTU) & 9.8 & 477 & 150 & 132 & 124 & 164 & 41,0 & 4,3 & 448,2 & 154 & 49,8 & 6,6 \\
\hline
\end{tabular}




\subsubsection{Gama de condutividade elétrica das águas}

No capítulo anterior mostrou-se que no caso da Nhecolândia há uma distribuição bimodal da condutividade elétrica das águas de superfície. A segunda moda recobre a faixa de CE de 1000 a $70000 \mu S . \mathrm{cm}^{-1}$, ou seja, a faixa que corresponde às águas das salinas.

A Figura 30 apresenta a gama de condutividade elétrica das águas das salinas, que varia de 500 a $60000 \mu$ S. $\mathrm{cm}^{-1}$, sendo a maioria acima de $1000 \mu \mathrm{S} . \mathrm{cm}^{-1}$. Esses valores mostram que essas águas são representativas da gama regional, e confirmam seus enquadramentos na segunda moda da distribuição regional da CE.

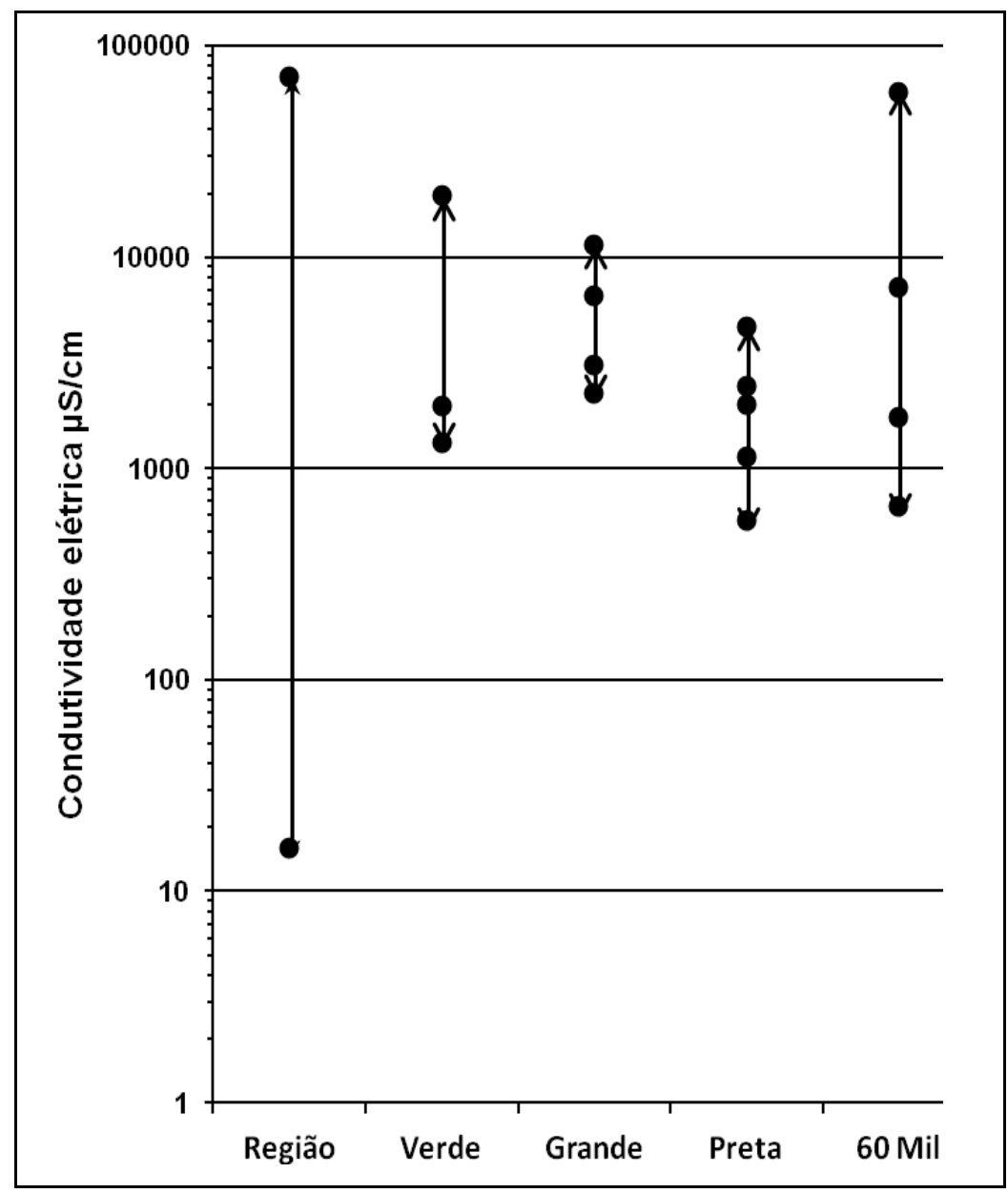

Figura 30. Gama da condutividade elétrica das águas de superfície na Nhecolândia, e as das salinas estudadas. Os pontos pretos representam os valores de CE medidos in situ de 2009 a 2011. 
A Tabela 9 destaca, nesse período, que a relação entre condutividade máxima e mínima é pequena, da ordem de 5, na Salina Grande, e grande, próxima de 100, nas Salinas 60 Mil, Verde e Preta. Nota-se também que as variações de pH não acompanham, necessariamente, essas variações de condutividade.

Tabela 9. Relação condutividade máxima e mínima, pH máximo e mínimo das águas das salinas de setembro de 2009 a julho de 2011.

\begin{tabular}{lcccc}
\hline & Verde & Grande & Preta & $\mathbf{6 0}$ Mil \\
\hline CEmax/CEmin & 14,641 & 5,0978 & 8,2456 & 91,654 \\
pHmax/pHmin & 2,95 & 0,4 & 0,59 & 0,22 \\
\hline
\end{tabular}

\subsubsection{Oxigênio dissolvido e condições redox nas águas e sedimentos.}

Do mesmo modo que a CE, os valores de saturação em oxigênio dissolvido (OD\%) apresentam forte variabilidade, de 10\% a 400\% aproximadamente. Salientase que esses valores são apenas indicativos, apesar de certamente refletirem fortes variações diárias. Isto porque se percebe que os menores valores correspondem às medidas efetuadas no período da manhã, e os maiores as de final de tarde. Entretanto, esses valores são indicativos de forte atividade biológica durante o dia com importante produção de oxigênio pela fotossíntese.

Os valores do potencial redox nos sedimentos são muito baixos, podendo atingir $-300 \mathrm{mV}$. As condições são, portanto, muito reduzidas, com grande influência nos ciclos dos elementos maiores, sobretudo por estarem associadas a elevados valores de $\mathrm{pH}$.

A gama de valores de Eh e $\mathrm{pH}$ dos sedimentos das salinas é apresentada na Figura 31. Esse diagrama, de Pourbaix, mostra a predominância das diferentes 
formas de carbono relacionadas aos valores de Eh e $\mathrm{pH}$, juntamente com o domínio de estabilidade da água.

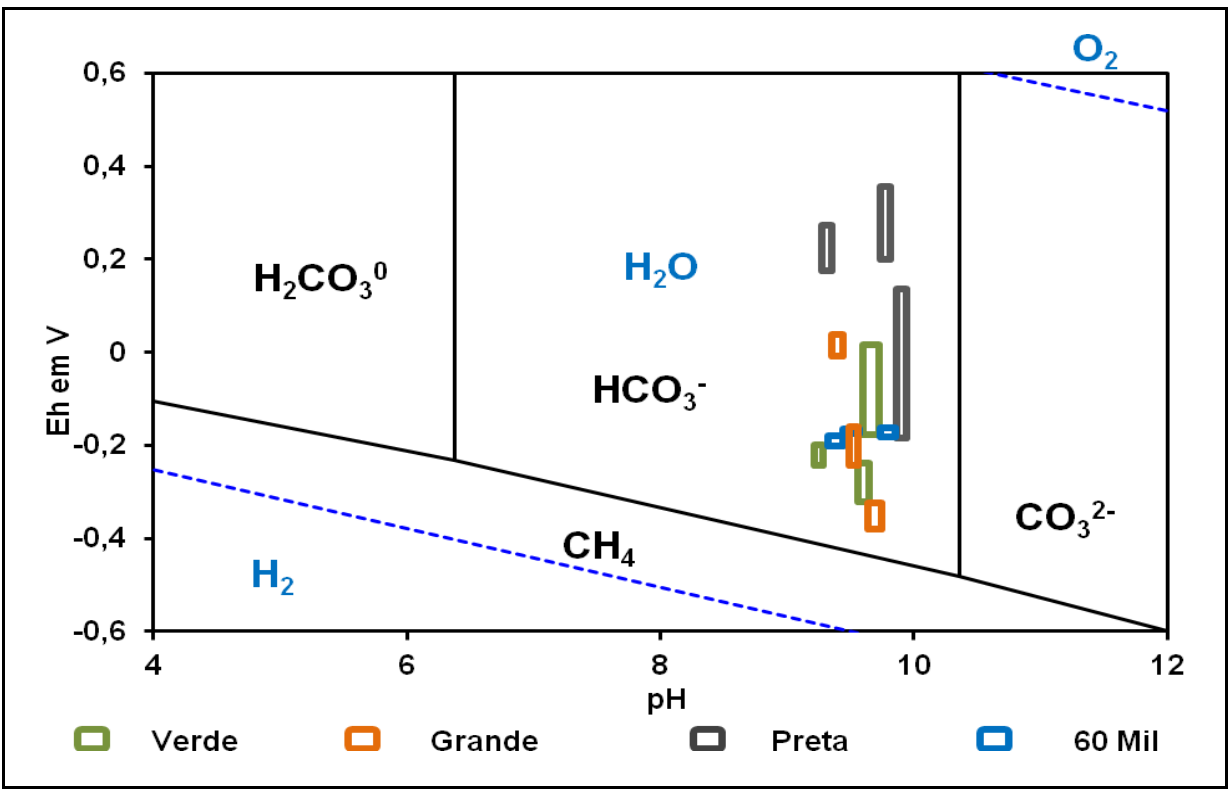

Figura 31. Gamas de pH-Eh observadas nos sedimentos das salinas.

\subsection{Mapeamento da CEa dos solos ao redor da Salina Verde}

Neste momento, serão apresentados somente os resultados do mapeamento da CEa dos solos da Salina Verde. Num segundo, esses resultados serão comparados aos das outras salinas.

\subsubsection{Mapeamento com o EM38}

A Figura 32 apresenta os 1512 pontos de medidas realizadas com o EM38(DMV) em posição vertical ao redor da Salina Verde. A Tabela 10 apresenta os resultados da estatística descritiva dos dados de CEa do solo.

O ambiente de entorno da Salina Verde é relativamente condutor de eletricidade, com valores de CEa que atingem até $250 \mathrm{mS} / \mathrm{m}$, cuja média é próxima de $100 \mathrm{mS} / \mathrm{m}$. 


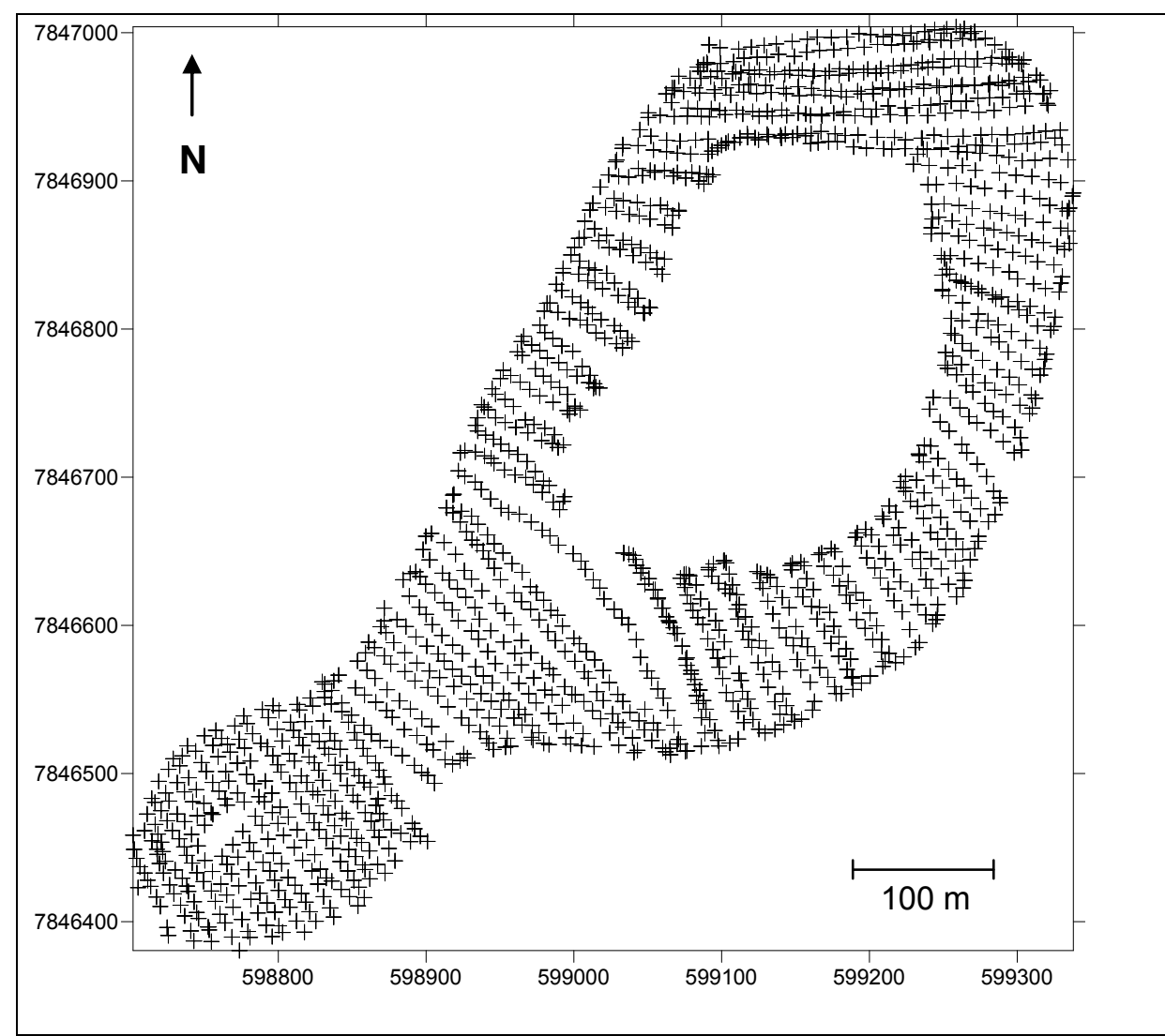

Figura 32. Pontos de medidas da CEa do solo na Salina Verde (EM38-DMV em posição vertical).

Tabela 10. Estatística descritiva.

\begin{tabular}{lc}
\hline Variáveis & CEa $(\mathrm{mS} / \mathrm{m})$ \\
\hline$N^{\circ}$ de Observações & 1512 \\
Mínimo & 47,588 \\
Máximo & 244,212 \\
Média & 98,66 \\
Variância (n) & 1080,50 \\
Desvio Padrão & 32,871 \\
Coeficiente de Variação & 33,31 \\
\hline
\end{tabular}

A Figura 33 apresenta o histograma dos valores de CEa. Nota-se que a distribuição desses valores é nitidamente bimodal, com a primeira moda centrada em $60 \mathrm{mS} / \mathrm{m}$, e a segunda em $110 \mathrm{mS} / \mathrm{m}$. Como essa repartição da gama de valores de CEa se aproxima de uma normal, esses dados podem ser diretamente utilizados, 
sem transformação logarítmica da $\mathrm{CEa}$ em $\log _{10}(\mathrm{CE})$, no estudo da distribuição espacial dessa variável.

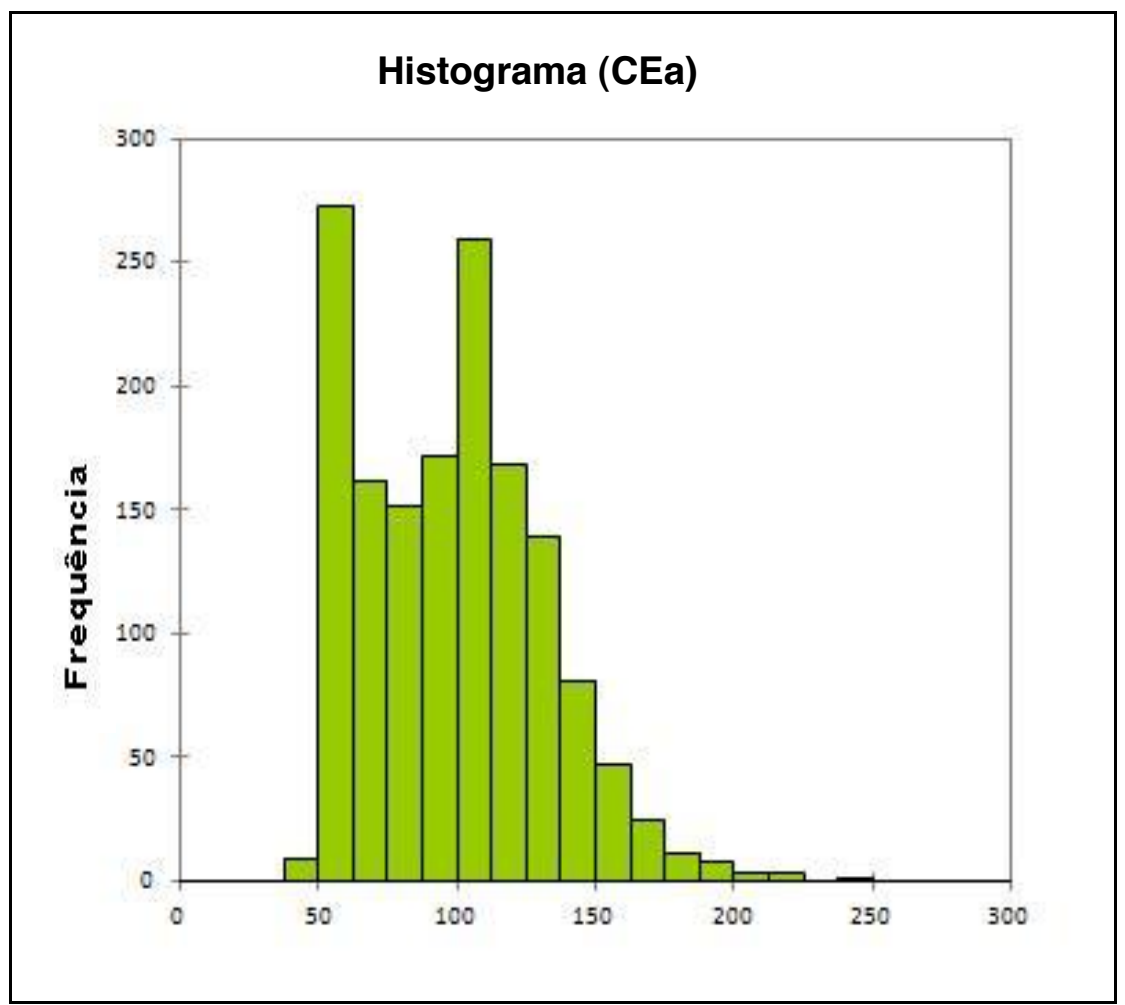

Figura 33. Histograma dos valores de CEa da Salina Verde (EM38-DMV).

O variograma experimental é apresentado na Figura 34. Ele se caracteriza pela ausência de efeito pepita, e por um patamar de $1000 \mathrm{mS}^{2} \cdot \mathrm{m}^{-2}$. O alcance é de $60 \mathrm{~m}$ aproximadamente. Esse variograma se ajustou a um modelo de tipo exponencial, com patamar de $1028 \mathrm{~ms}^{2} \cdot \mathrm{m}^{-2}$, e alcance de $42 \mathrm{~m}$. Este modelo serviu de base para confeccionar o mapa de distribuição de CEa apresentado na Figura 35.

O mapa da Figura 35 destaca que essa gama de valores de CEa se distribui em faixas, com forma de anéis contínuos a descontínuos ao redor da Salina Verde. Esse zoneamento traduz uma organização espacial da CEa centrada na Salina. 


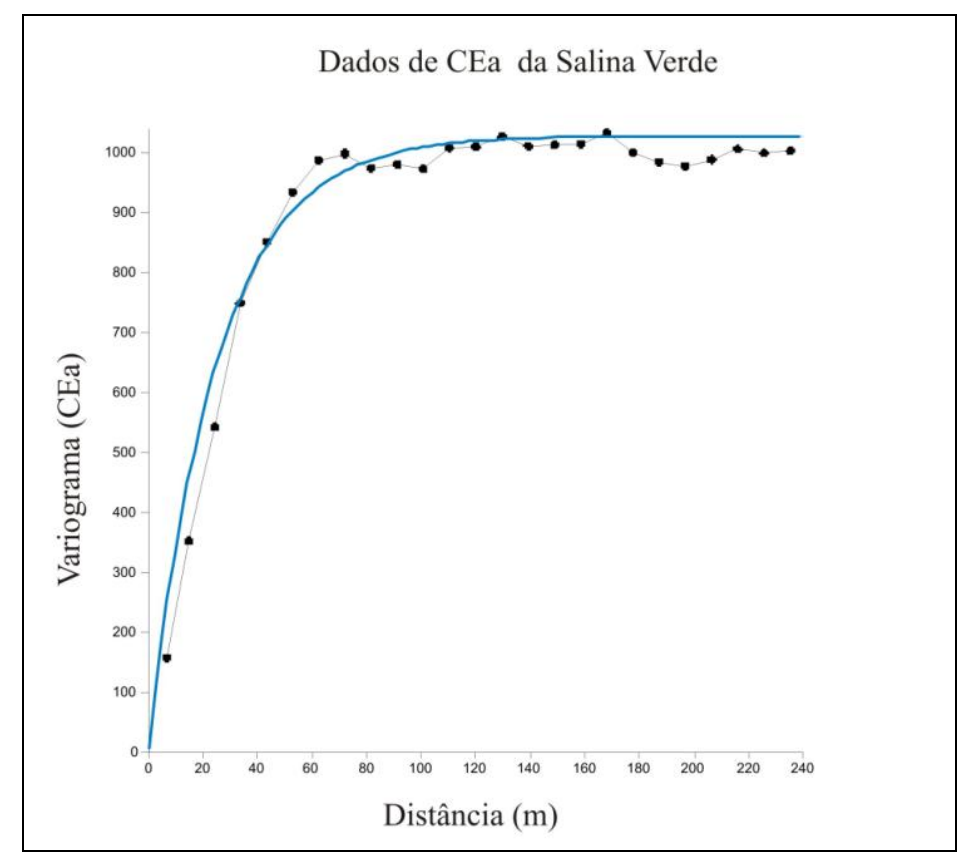

Figura 34. Variograma experimental dos dados de condutividade elétrica aparente (EM38), e a linha em azul, a do modelo ajustado.

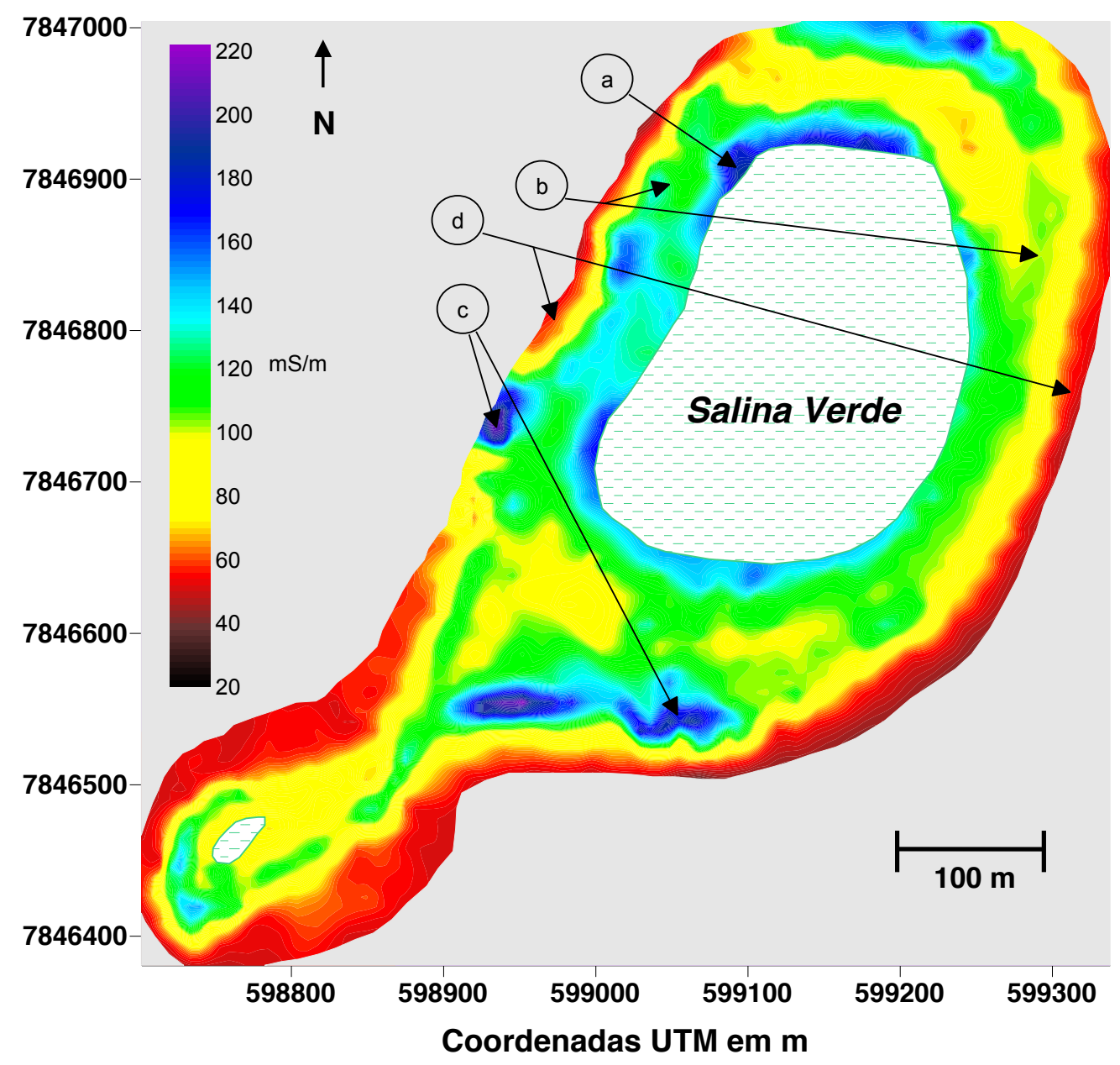

Figura 35. Mapa de distribuição da CEa ao redor da Salina Verde. 
Partindo-se da borda da salina em direção à cordilheira, nota-se:

(1) um primeiro zoneamento (a), em forma de anel descontínuo, localizado no entorno imediato da salina, corresponde aos valores de CEa entre 140 e 190 $\mathrm{mS} / \mathrm{m}$, e pontualmente, entre 190 e $220 \mathrm{mS} / \mathrm{m}$, estes os mais elevados da série;

(2) na sequência deste, aparece um segundo zoneamento (b) em forma de anel contínuo bem marcado, com CEa de 100 a $140 \mathrm{mS} / \mathrm{m}$. Este zoneamento se estende, quase contínuamente, até o divertículo da salina onde configura um semicírculo ao redor da pequena salina que aí se manisfesta;

(3) após este segundo zoneamento, observam-se manchas individualizadas (c) com CEa de 160 a $220 \mathrm{mS} / \mathrm{m}$ distribuidas em forma de um grande anel externo descontínuo, quase no limite da praia com a cordilheira;

(4) finalmente, um último zoneamento (d) é formado pelos valores mais baixos da série, entre 20 e $100 \mathrm{mS} / \mathrm{m}$. Percebe-se pelos valores deste zoneamento que a CEa diminui em direção à cordilheira, enquanto a topografia se eleva gradativamente.

\subsubsection{Comparação entre os mapeamentos EM38 Dipolos Magnéticos Vertical (DMV) e Horizontal (DMH).}

Lembra-se que o dipolo magnético em posição horizontal do EM38 prospecta melhor os horizontes superficiais. Estes horizontes influem muito pouco na resposta do aparelho em posição vertical. A Figura 36 apresenta os mapas do alongamento SW da Salina Verde feitos com base nas duas posições (Vertical e Horizontal) do aparelho. Os histogramas com as gamas de valores da CEa desses mapas aparecem na Figura 37. 

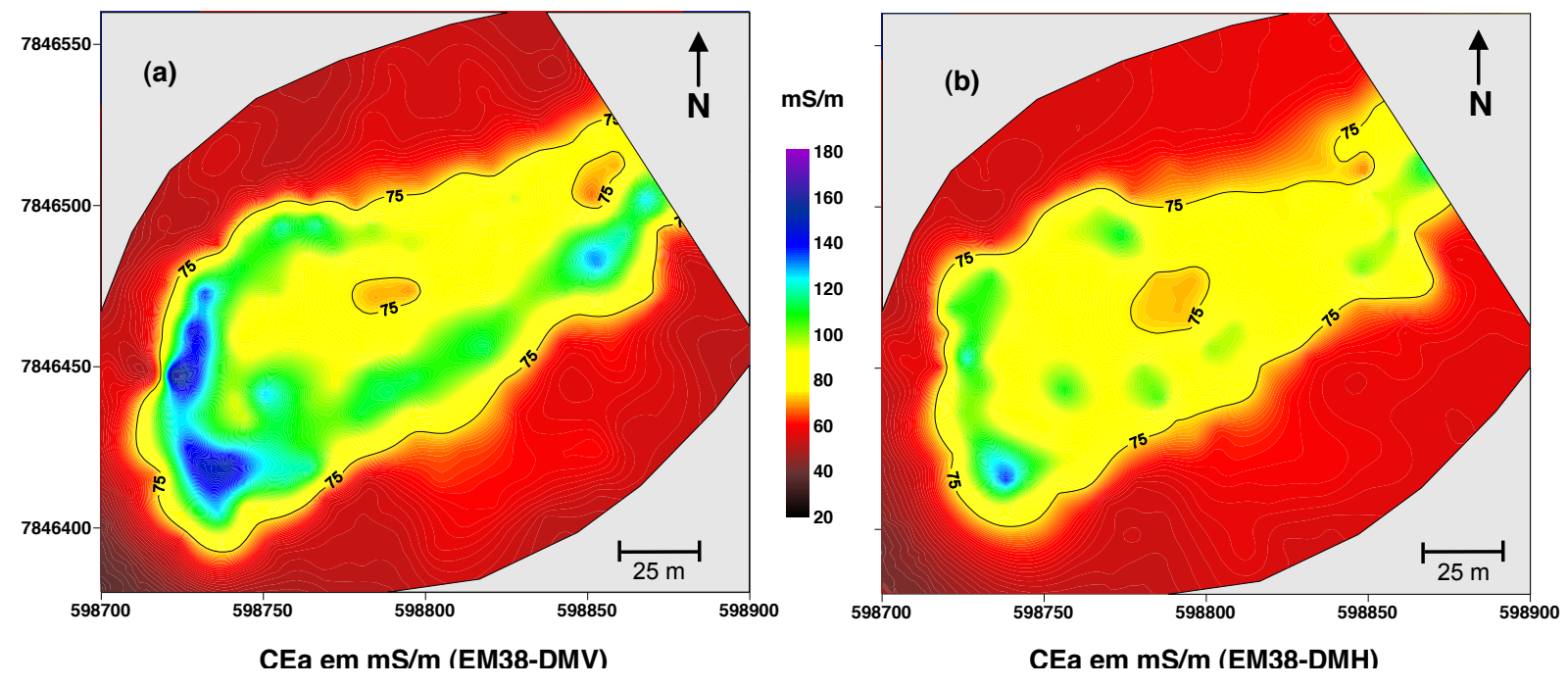

Figura 36. Mapas da distribuição da condutividade elétrica aparente (CEa) no alongamento SW da Salina Verde: (a) EM38-DMV e (b) EM38-DMH.
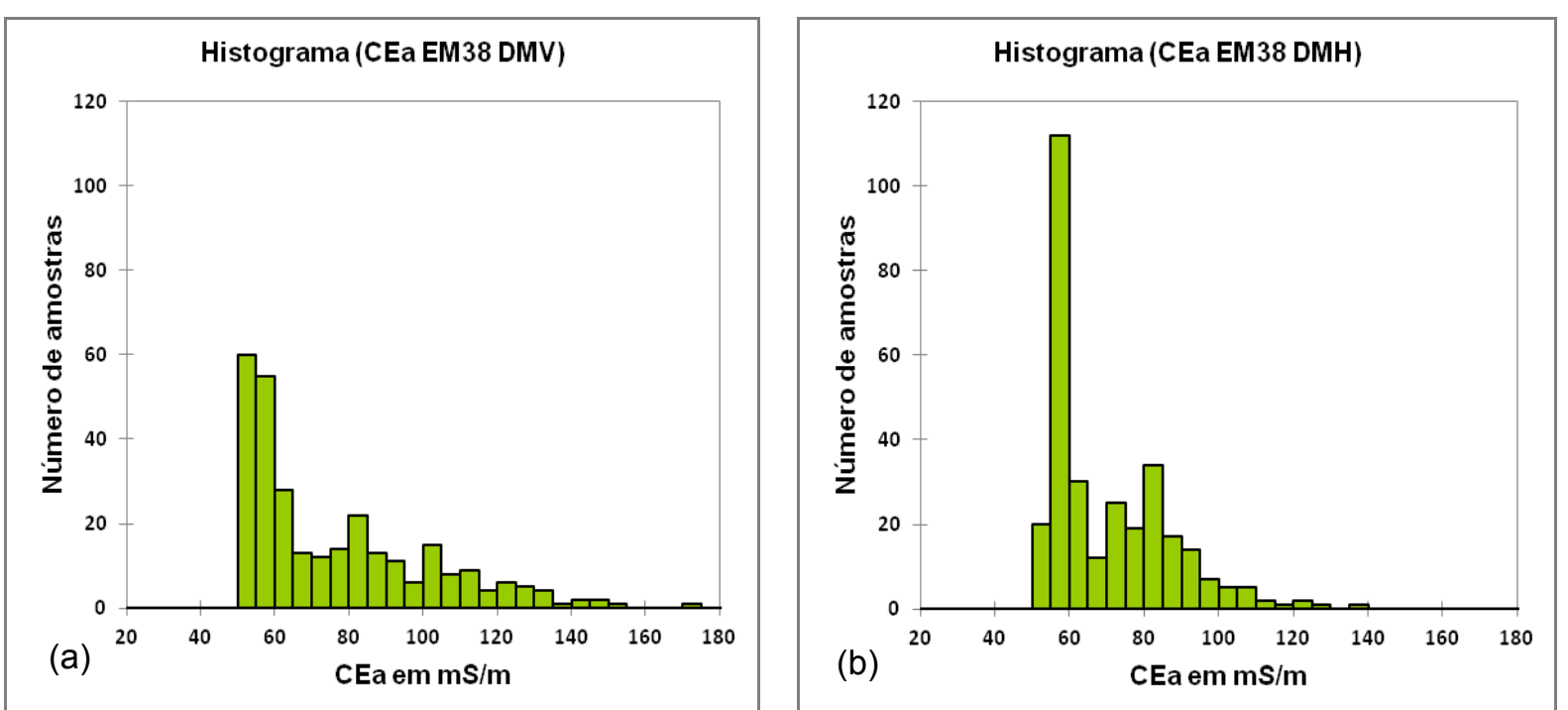

Figura 37. Histograma de distribuição dos valores de CEa: (a) EM38- DMV e (b) EM38-DMH.

Comparando-se os dois mapas da Figura 36 percebe-se: (1) que as linhas de isovalores de CEa a $75 \mathrm{mS} / \mathrm{m}$ ocupam as mesmas posições. Isto mostra que a distribuição dos baixos a médios valores de CEa são similares nos dois mapas; (2) ao contrário, os valores mais elevados, superiores a $100 \mathrm{mS} / \mathrm{m}$, são muito atenuados no mapa com os valores obtidos em posição horizontal (DMH) do EM38, fato que se confirma pelo histograma da Figura 37. Em síntese, no mapa da Figura 36-b se observa o desaparecimento da informação sobre as zonas mais condutoras 
registradas pelo aparelho em posição vertical (DMV) da Figura 36-a. Este dado indica que os horizontes mais condutores se localizam em profundidades superiores a $1 \mathrm{~m}$.

A prospecção do EM38 é muito mais eficaz do que o EM31 nos primeiros 20 centímetros do solo, e por isto, os horizontes mais condutores localizados nessa faixa de profundidade ficam melhores definidos nos mapas. Porém, abaixo dessa faixa, as variações de CEa não podem mais ser identificadas pelo EM38, e passam a ser melhor captadas pelo EM31, cuja profundidade de prospecção atinge até $6 \mathrm{~m}$.

\subsubsection{Mapeamento com o EM31}

Utilizou-se o EM31 para identificar a distribuição espacial da CEa dos horizontes mais profundos ao redor das salinas. O cruzamento das respostas dos dois aparelhos permitiram observar mudanças na cobertura pedológica e identificar correspondências entre os mapas delas resultantes.

O mapa dos valores de CEa obtidos com o EM31-DMV em posição vertical é apresentado na Figura 38. As organizações que aparecem neste mapa são muito similares às do mapa de CEa obtidos com o EM38-DMV em posição vertical. Entretanto, registram-se algumas diferenças: (1) a gama de valores de CEa medidos pelo EM31 com um máximo de $120 \mathrm{mS} / \mathrm{m}$, corresponde, aproximadamente, à metade dos medidos pelo EM38; (2) em profundidade, os valores de CEa não aumentam na proximidade imediata da salina, indicando que o horizonte mais condutor é, neste caso, o horizonte superficial. 


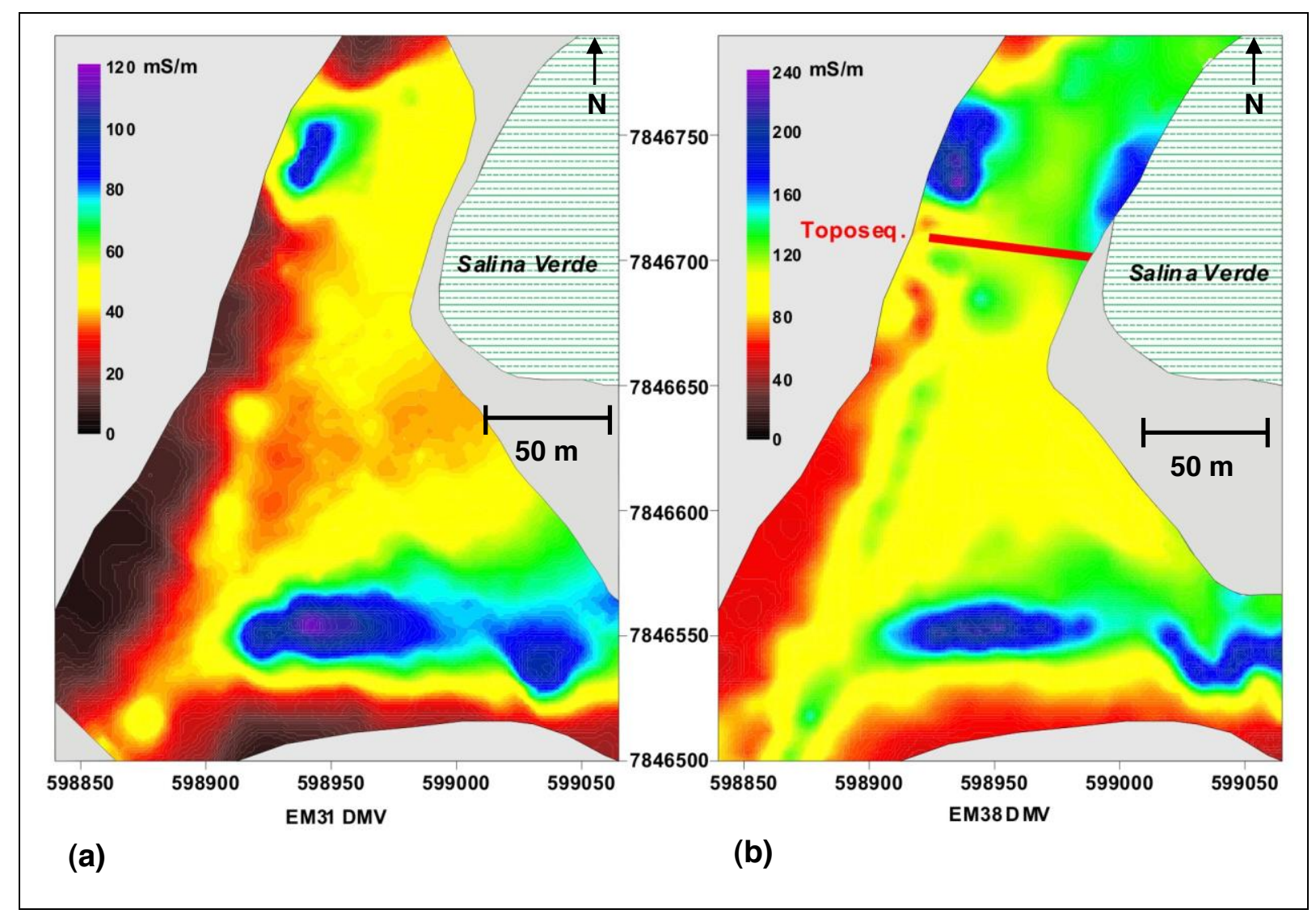

Figura 38. Mapas de distribuição da CEa na porção SW da Salina Verde: (a) EM31DMV e (b) EM38-DMV; localização da sequência de solo em vermelho.

\subsection{O solo na Salina Verde}

O mapeamento por indução eletromagnética coloca em evidência fortes contrastes de CEa, cujos valores são distribuídos em forma de anéis concêntricos, mais ou menos contínuos, ao redor da Salina Verde. Nesta etapa do trabalho, o objetivo é verificar se existe correspondência entre essa distribuição e a morfologia dos solos. Com este objetivo, estudou-se uma sequência de solos na praia oeste da Salina Verde, cujo traçado procurou recortar as principais variações observadas de CEa (Figura 38). Ao longo dessa sequência também foram efetuadas medidas pontuais de CEa. 
A Tabela 11 apresenta as variações da CEa (EM38-DMV) nessa sequência. A gama total de valores é de 96 a $120 \mathrm{mS} / \mathrm{m}$, com grandes oscilações de um ponto a outro.

Tabela 11. Valores de CEa na sequência de solos da Salina Verde.

\begin{tabular}{lcccccccc}
\hline Ponto & T1 & T8 & T2 & T3 & T4 & T5 & T6 & T7 \\
\hline CEa EM38-DMV em mS/m & 96 & 123 & 99 & 104 & 118 & 111 & 114 & 120 \\
\hline
\end{tabular}

\subsubsection{Características morfológicas e físico-químicas do solo}

A sequência se inicia no limite da cordilheira com a praia e segue até a borda da salina (Figura 39). Esse perfil tem 54,30 metros de comprimento, e um desnível de 1,07 metros. As descrições morfológicas da trincheira e das sondagens estão no Anexo 1. A Figura 40 apresenta a sequência de solo, e a Figura 41, as classes texturais dos horizontes.

Partindo-se da cordilheira (T1), e do topo para a base do perfil, observa-se uma sucessão vertical dos seguintes horizontes: (1) horizonte arenoso bege claro; (2) horizonte arenoso verde claro; (3) horizonte cinza escuro, plástico, com estrutura pouco nítida, e textura argilo-arenosa no topo e arenosa na base; e (4) horizonte verde silto-arenoso endurecido. Do lado oposto, na borda da salina, também se observam 4 horizontes do topo para a base do perfil: (5) horizonte superficial orgânico com $30 \mathrm{~cm}$ de espessura, e textura areia franca; (6) horizonte arenoso verde escuro; (7) horizonte verde com textura franco-argilo-arenosa a francoarenosa, cuja matriz cinza esverdeada apresenta volumes endurecidos verdes escuros e marrons; (8) horizonte cinza claro com textura no limite das classes arenosa e areia franca. 


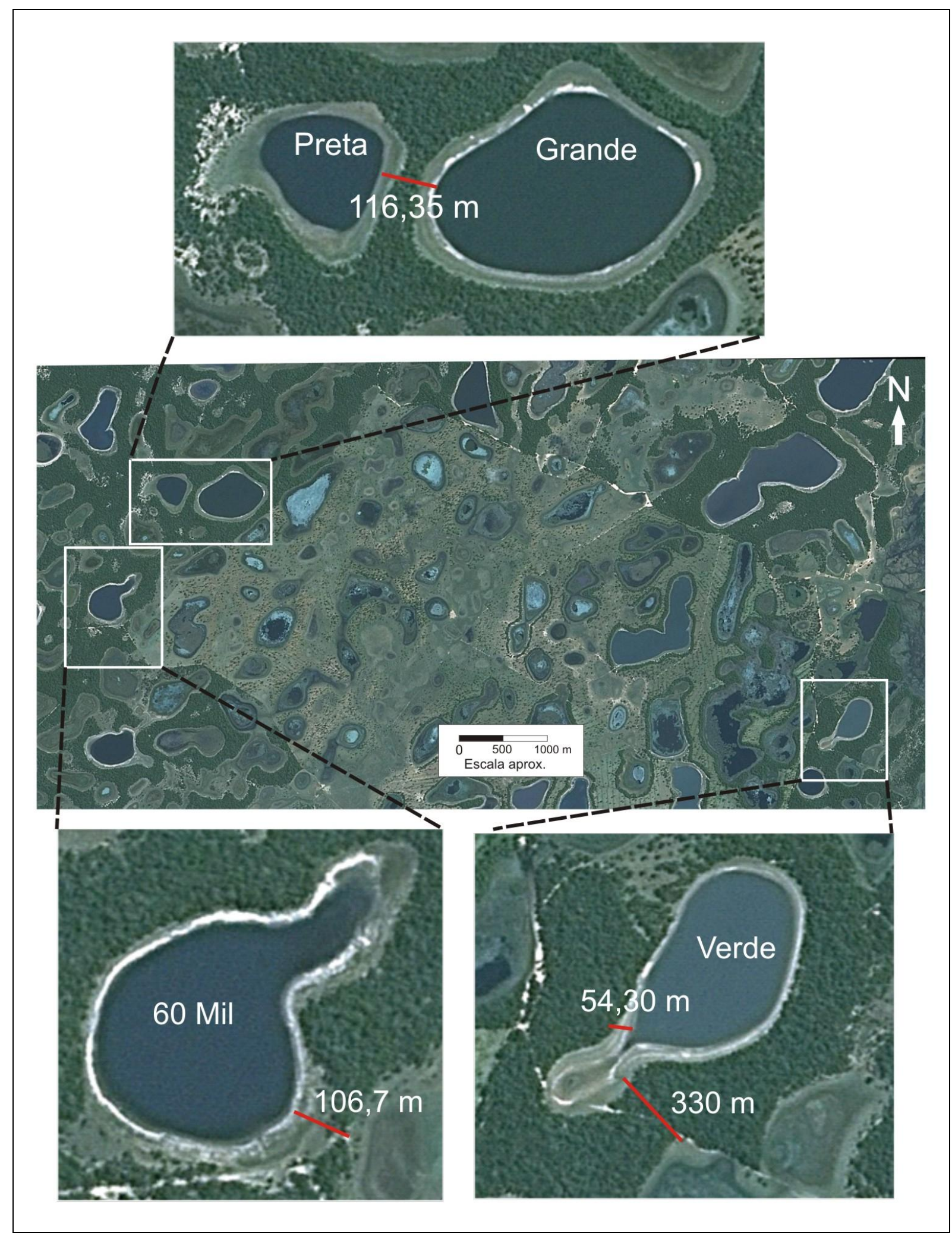

Figura 39. Localização das sequências de solos (em vermelho) nas Salinas Preta e Grande, 60 mil e Verde (Fonte: Imagem Google Earth, 2010). 

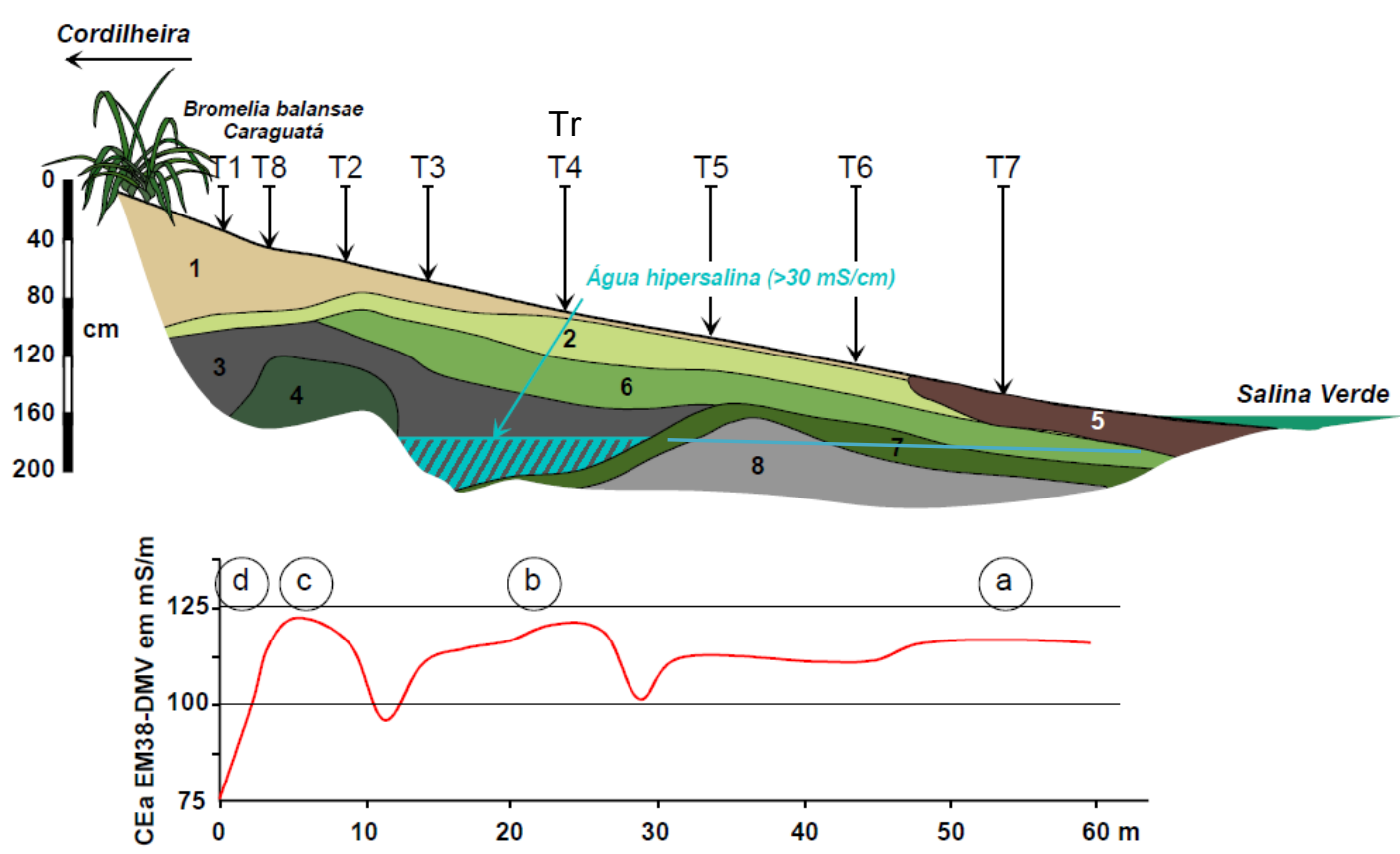

Legenda:

1 Horizontes T1 Tradagens (a) Setores de CEa Tr Trincheira

Elaboração: Barbiéro, 2012.

Figura 40. Sequência de solos da Salina Verde com as organizações vertical e lateral dos horizontes e gráfico da distribuição da CEa (EM38-DMV).

A distribuição lateral dos horizontes não é progressiva, mas marcada por ondulações acentuadas dos limites entre horizontes. O horizonte superficial (1) é espesso junto à cordilheira, afina-se abruptamente em T2, e depois progressivamente até $\mathrm{T} 4$, a partir do qual permanece com 2 a $4 \mathrm{~cm}$ de espessura até desaparecer entre T6 e T7. A espessura dos horizontes (2) e (6) são, grosso modo, constantes, sendo o (2) mais fino sob o horizonte (1), e o (6) sob o horizonte (5). Os horizontes (2) e (6) se prolongam até a borda da lagoa, onde o horizonte (2) desaparece, e o (6) se aloja sob o horizonte (5). O horizonte (3) é mais espesso entre T2 e T4, e se afina progressivamente para desaparecer no ponto T5, onde é substituído pelo horizonte (7). O horizonte endurecido (4) aparece em forma de coifa somente na base da sequência, entre os pontos T1 e T2, e apresenta uma elevação 
no ponto T8. À jusante, o horizonte (5) de superfície desaparece progressivamente entre T6 e T7.

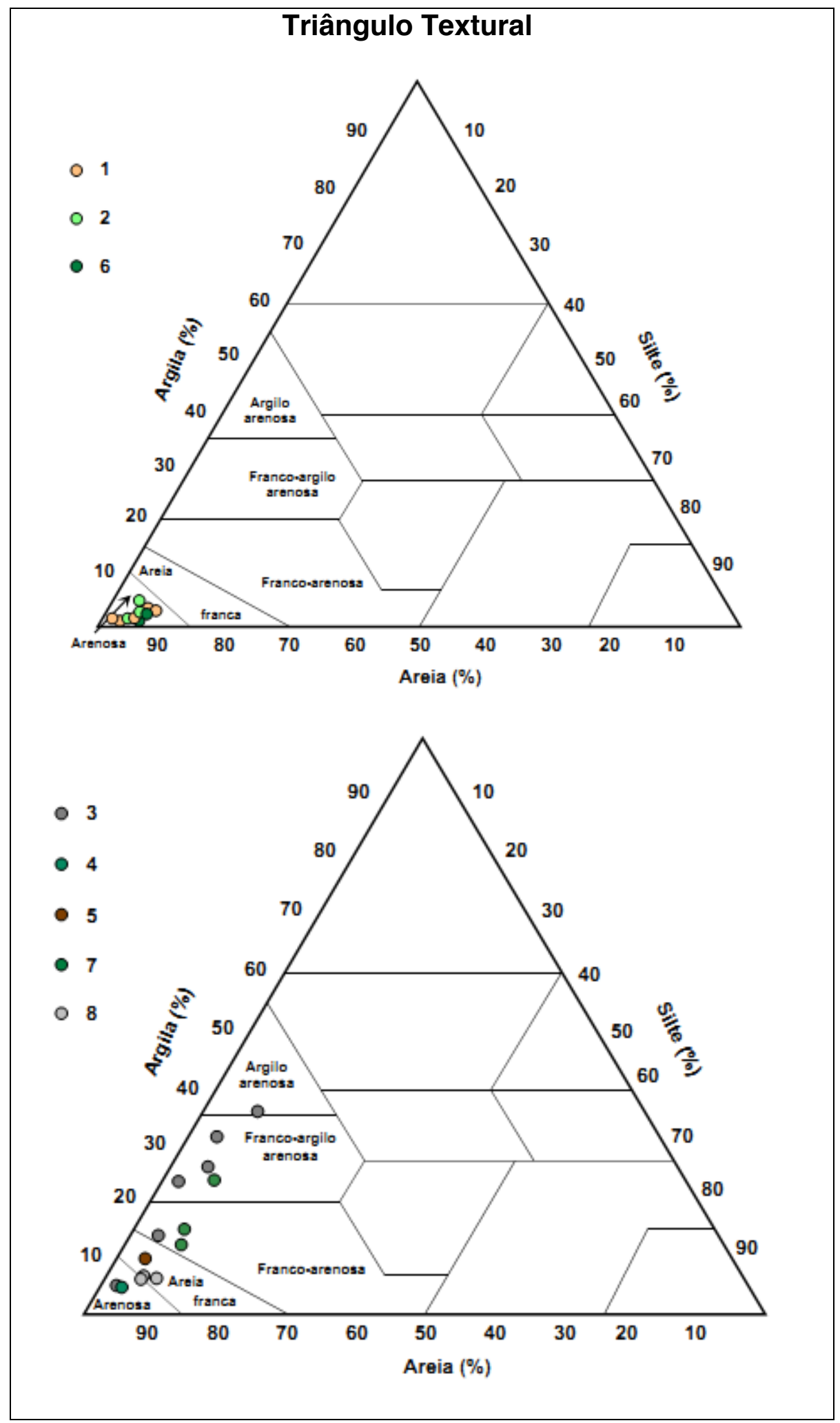

Figura 41. Triângulo de textura dos horizontes da sequência de solo da Salina Verde. 
A cor verde dos horizontes (2) e (6) não se altera ao ser exposta ao ar, mas desaparece durante o tratamento da amostra com $\mathrm{H}_{2} \mathrm{O}_{2}$, comprovando tratar-se de matéria orgânica. Efetivamente, observações de amostras desses horizontes feitas com uma lupa mostram que essa cor é dada pela presença de algas recobrindo os grãos de areia, sobre os quais formam finas películas. Portanto, essa coloração é provocada pela elevação do nível da água da salina durante a estação chuvosa, que quando abaixa, na estação seca, produz um depósito de algas nos interstícios dos grãos de areia. Ao contrário da cor verde dos horizontes (4) e (7) que se altera para tons amarelados ao ser exposta ao ar, comprovando não estar ligada a algas, mas ao estado do ferro contido no fundo matricial argiloso.

Considerando-se que a estrutura maciça predomina em todos os horizontes, a do horizonte (3) é tão pouco desenvolvida que nem pode ser considerada, as principais diferenciações morfológicas observadas entre os horizontes se restringem à cor, à textura, e ao grau de cimentação dos constituintes que aparece somente em profundidade. A base do horizonte (3), de T3 até a meia distância entre T4 e T5, é saturada por uma água muito salina, cuja condutividade elétrica, medida em julho de 2011 , foi superior a $30.000 \mu$ S. $\mathrm{cm}^{-1}$.

Os dados de textura apresentados na Figura 41, e Anexo 2, permitem distinguir na sequência dois grupos de horizontes. Um grupo composto pelos horizontes arenosos (1), (2) e (6), de superfície e sub-superfície, cuja textura se enquadra na classe arenosa; e outro grupo, formado pelos horizontes profundos (3), (4) e (6), com teores em argila entre 10 a 38\%, cuja textura oscila entre as classes areia-franca, franco-arenosa, franco-argilo-arenosa e argilo-arenosa. Entretanto, ocorrem duas exceções, uma diz respeito ao teor em argila próximo de $10 \%$ do horizonte (5), superficial, situado na borda imediata da salina à jusante; e a outra, à 
textura mais grosseira do horizonte (8) em profundidade. Neste grupo, a fração argila é composta de argilo-minerais tipo caulinita, ilita e esmectita, mais minerais primários, quartzo e traços de feldspato (Anexo 3).

O complexo de troca (Figura 42 e Anexo 4) é saturado em sódio, cujos teores abrangem uma grande gama de valores, com os menores abaixo de $2 \%$ e os maiores acima de $50 \%$. Estes altos valores aparecem no topo do horizonte (3) e na base do horizonte (2), mas sobretudo no (6), na porção acima do lençol de água hipersalina. Os valores são ainda altos, de 30 a $45 \%$, na parte superior dos horizontes (4) e (7), mas diminuem em profundidade nos horizontes (3) e (8), para atingir menos de $5 \%$.

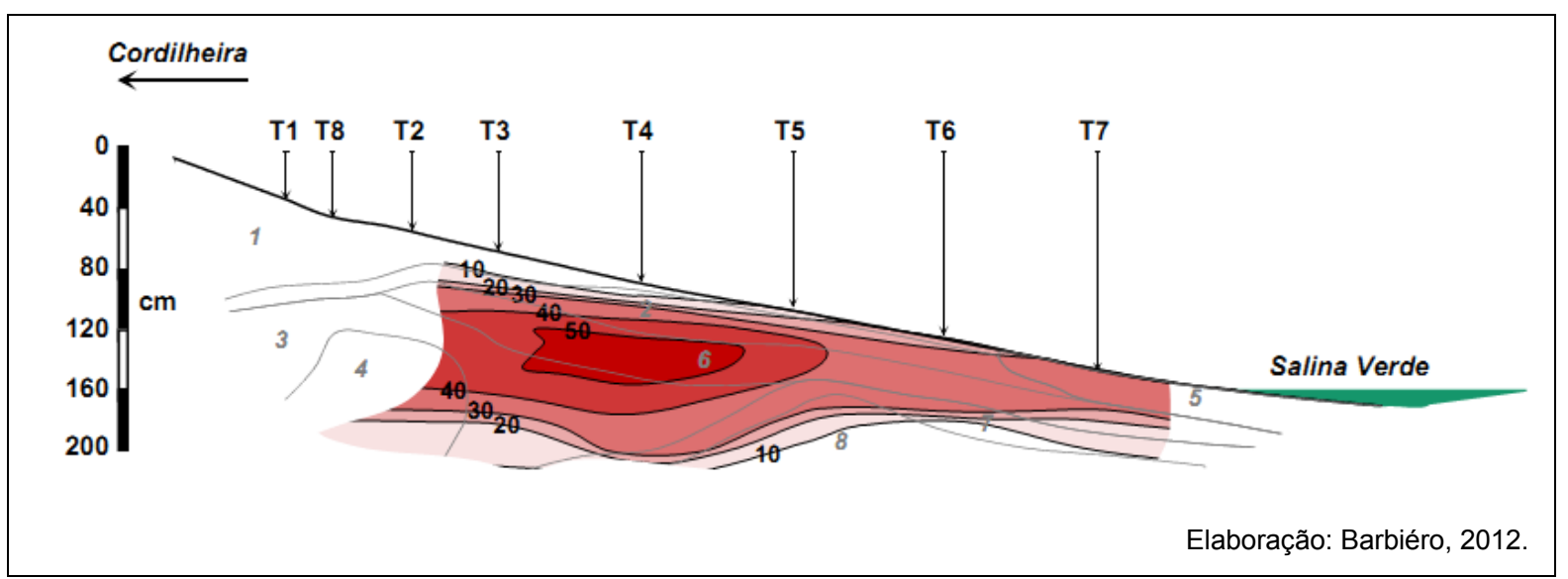

Figura 42. Distribuição do sódio trocável em \% da capacidade de troca.

Esta saturação em sódio é excepcional e afeta a estrutura do solo, sendo, portanto responsável pela estrutura maciça observada no conjunto dos horizontes. Em geral, observa-se perda de estrutura a partir de 15\% de sódio trocável (Soltner, 1979), e este é o caso na maior parte dos horizontes estudados nessa sequência da Salina Verde. Além disto, e por sua monovalência, o sódio não é um íon prioritário de fixação no complexo de troca, em decorrência, altos teores em sódio trocável 
geralmente correspondem a graus elevados de alcalinização e sodicização dos solos.

A distribuição dos valores de $\mathrm{pH}$ é apresentada na Figura 43. Os gradientes são muito elevados nos horizontes superficiais, onde rapidamente os valores passam de 5,5 a 10. No horizonte (6) também são registrados altos valores de $\mathrm{pH}$, mas que progressivamente diminuem em direção à base do horizonte (3), e francamente no horizonte (8).

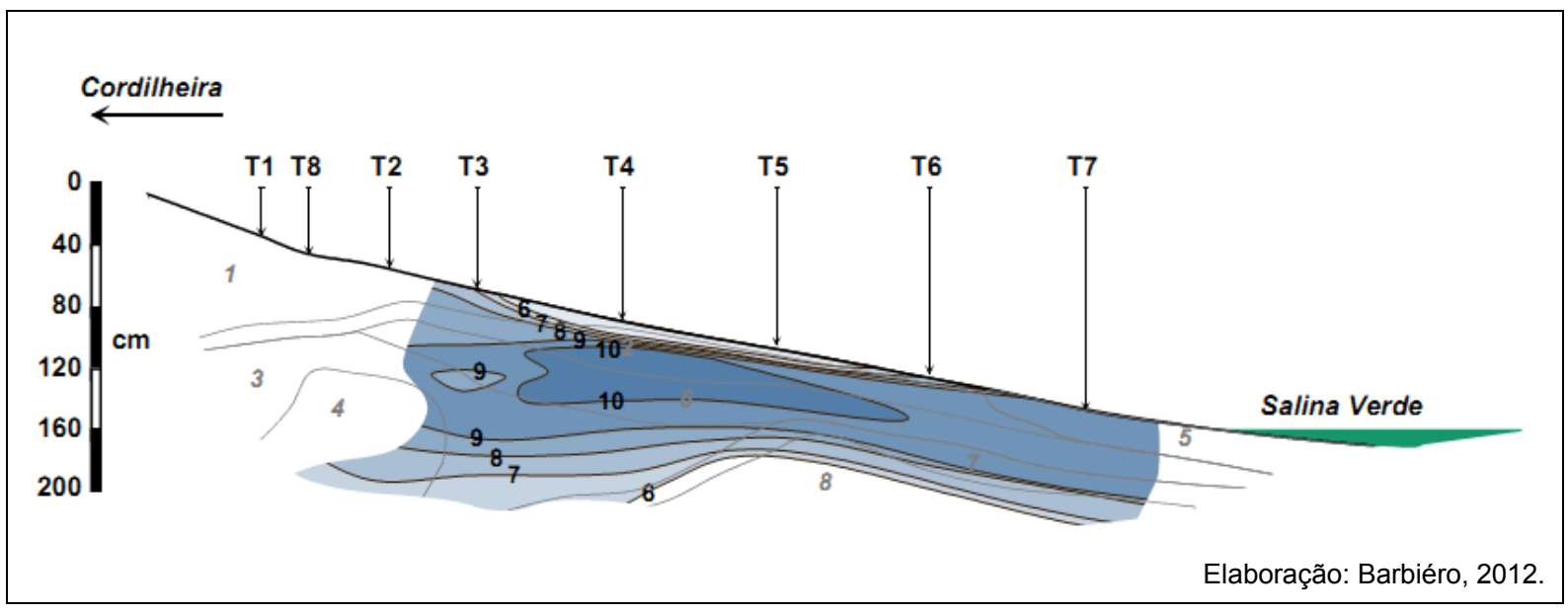

Figura 43. Distribuição do $\mathrm{pH}\left(\mathrm{H}_{2} \mathrm{O}\right)$ do solo.

\subsubsection{Morfologia e condutividade elétrica aparente do solo}

O estudo dessa sequência possibilitou ligar morfologia do solo e distribuição dos valores de CEa, cujas oscilações configuram 4 setores, a saber: (a), (b), (c) e (d) apresentados no gráfico da Figura 40.

O setor (a), com CEa de 112,5 mS/m, é situado na proximidade da Salina Verde e corresponde ao horizonte (5) superficial. Este horizonte apresenta textura um pouco mais fina que os horizontes (1) e (2), com um teor em argila próximo a 10\%. O segundo setor (b) está ligado a um pequeno aumento da CEa, de 112,5 para $118 \mathrm{mS} / \mathrm{m}$, e coincide com a presença da água hipersalina armazenada na base do 
horizonte (3). Na estação seca esta água se apresenta muito mais concentrada do que a água da salina, com valor de CE de $80.000 \mu \mathrm{S} . \mathrm{cm}^{-1}$. O setor (c) apresenta um pico de altos valores de CEa, os mais altos dessa série, de 118 a $122 \mathrm{mS} / \mathrm{m}$, que corresponde a uma subida abrupta do horizonte endurecido (4). A resposta em termos de valores de CEa depende, provavelmente, da espessura dessa camada cimentada.

Finalmente, o setor (d) apresenta uma forte queda nos valores de CEa, que passa de 122 para $75 \mathrm{mS} / \mathrm{m}$, portanto, os mais baixos da série. Essa queda é concordante com duas características da cobertura pedológica: de um lado, a elevação da topografia e o aumento da espessura dos horizontes arenosos superficiais, de outro, o mergulho do horizonte (4) em profundidade.

\subsection{Morfologia e condutividade elétrica aparente dos solos na cordilheira}

Em direção à cordilheira observa-se que o horizonte arenoso superficial (1) se torna mais espesso e atinge mais de $2 \mathrm{~m}$, que corresponde ao setor (d) acima descrito. Considerando-se que o contato deste horizonte com o horizonte subjacente se situa fora do campo de investigação do EM38, recorreu-se ao EM31 para mapear a CEa do solo na cordilheira.

Fez-se um corte de $330 \mathrm{~m}$, saindo da Salina Verde, passando pela cordilheira, até uma baía localizada a SE. No período de cheia, esta baía se conecta temporariamente com a Vazante do Castelo. A Figura 44-a apresenta uma síntese simplificada da morfologia do solo desse corte, onde se distinguem os horizontes arenosos superficiais e os horizontes profundos com textura mais fina, e teores de 15 a $30 \%$ de argila. Os valores de CEa obtidos com o EM31, em posição vertical (DMV) estão apresentados na Figura 44-b. 
O solo é constituído basicamente de areia, cor bege clara, cujo total varia de 94 a 97\%, com predominância das frações areia fina a muito fina, que se torna progressivamente mais fina e branca em profundidade. O contato entre esses dois conjuntos de horizontes, arenosos superficiais e endurecidos profundos, tem forma ondulada, e é geralmente abrupto, com uma transição que se faz em menos de 10 $\mathrm{cm}$.

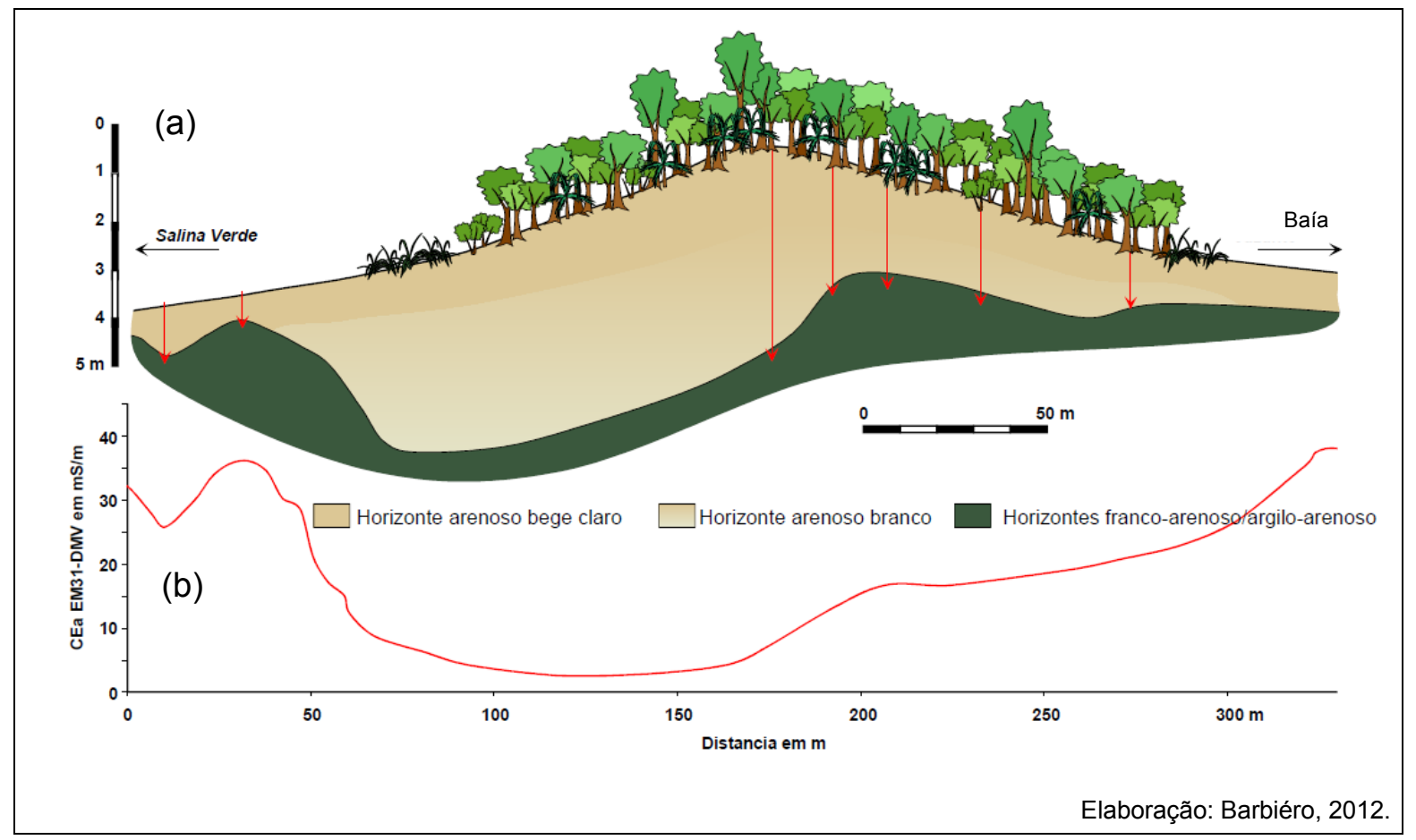

Figura 44. Sequência de solo entre a Salina Verde, a Cordilheira e a Baía (a); Perfil dos valores de CEa (EM31-DMV) nessa sequência (b).

A forma da curva dos valores de CEa segue as principais ondulações desse contato, e indica que a resposta do aparelho é determinada pela profundidade do contato. O agenciamento morfológico desses horizontes superficiais e profundos mostra a presença de duas elevações, que juntas formam uma espécie de vale em U dissimétrico. A primeira ondulação aparece na extremidade da cordilheira próxima à baía, a uma profundidade de $205 \mathrm{~cm}$, e ligeiramente deslocada em relação ao ponto topográfico mais alto da cordilheira. A segunda aparece próxima à Salina 
Verde, a $35 \mathrm{~cm}$ de profundidade, também registrada na carta de CEa feita com os dados do EM38-DMV.

\subsection{Morfologia e CEa dos solos das outras salinas}

A seguir, serão apresentados os estudos morfológicos das outras 3 salinas.

\subsubsection{Salina Preta}

O mapeamento EM38-DMV ao redor da Salina Preta foi feito em dois períodos, o primeiro em maio de 2010, após uma seca prolongada e uma estação chuvosa muito curta, e o segundo em julho de 2011, após uma estação chuvosa marcada por índices pluviométricos excepcionais, com grande acúmulo de chuvas. O mapa é apresentado na Figura 45, e destaca a variação do nível da água nesse período.

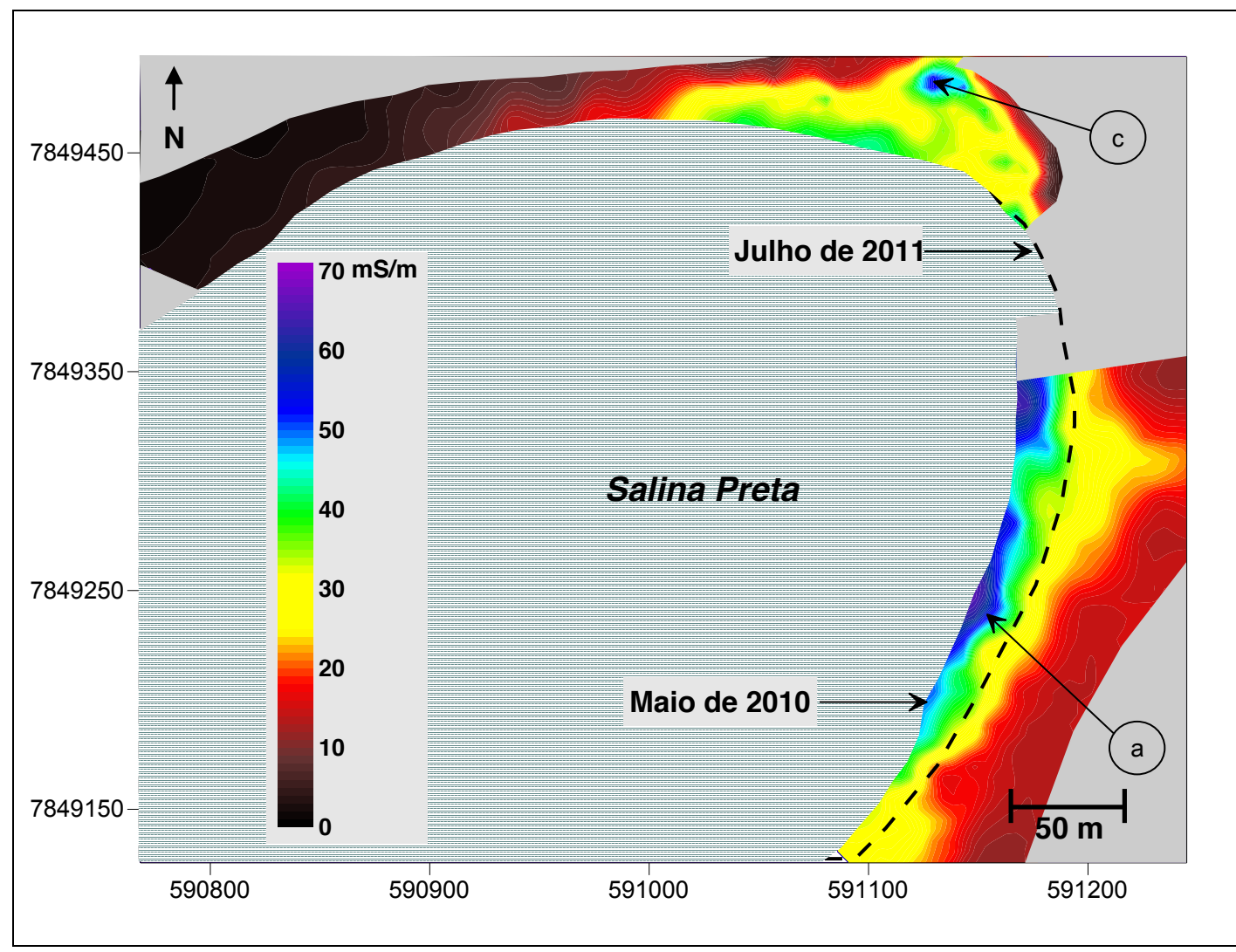

Figura 45. Distribuição dos valores de CEa ao redor da Salina Preta, e em preto pontilhado variação do nível da água na salina. 
A gama de valores da CEa é bem menor do que a da Salina Verde, de 0 a $70 \mathrm{mS} / \mathrm{m}$. O valor mais alto, de $70 \mathrm{mS} / \mathrm{m}$, se localiza na borda imediata da Salina Preta, no setor (a) do mapa. Nota-se que esse setor (a) desaparece com a subida das águas em 2011.

O setor (b) presente no mapa de CEa da Salina Verde (Figura 40), não aparece neste mapa da Salina Preta, e o setor (c) ocorre somente a NE, em um ponto isolado, com apenas algumas dezenas de metros.

Os valores de CEa desses dois setores (a) e (c) são da ordem de 60 à 70 $\mathrm{mS} / \mathrm{m}$, ao contrário da Salina Verde, onde o setor (a) é de 140 a $180 \mathrm{mS} / \mathrm{m}$ e o (c) de 180 a $220 \mathrm{mS} / \mathrm{m}$.

Os tons de cores utilizados nesse mapa da Figura 45 individualizam porções diferenciadas de valores de CEa. Contudo, acentuam contrastes de CEa que na realidade, não são tão marcantes, já que a gama é pequena e os valores são baixos. Mesmo assim, percebe-se que os valores de CEa diminuem nitidamente para oeste, onde o horizonte arenoso de superfície é mais espesso e de cor branca.

\subsubsection{Salina Grande}

A Figura 46 apresenta o mapeamento EM31-DMV feito nas praias das Salinas Preta e Grande, as quais foram ligadas por um perfil atravessando a cordilheira. A mesma escala de cores usada para as duas acentua a diferença entre as gamas de valores de CEa apresentadas por cada uma dela. Do lado da Salina Preta, a gama de valores é de 0 a um máximo aproximado de $70 \mathrm{mS} / \mathrm{m}$, enquanto que na da Salina Grande os valores máximos atingem 220 mS/m. Estes máximos são superiores aos identificados na praia da Salina Verde, que é de $120 \mathrm{mS} / \mathrm{m}$. A localização desses altos valores de CEa equivalem na Salina Verde aos locais da 
praia onde se observa uma elevação do horizonte endurecido (4) em direção à superfície.

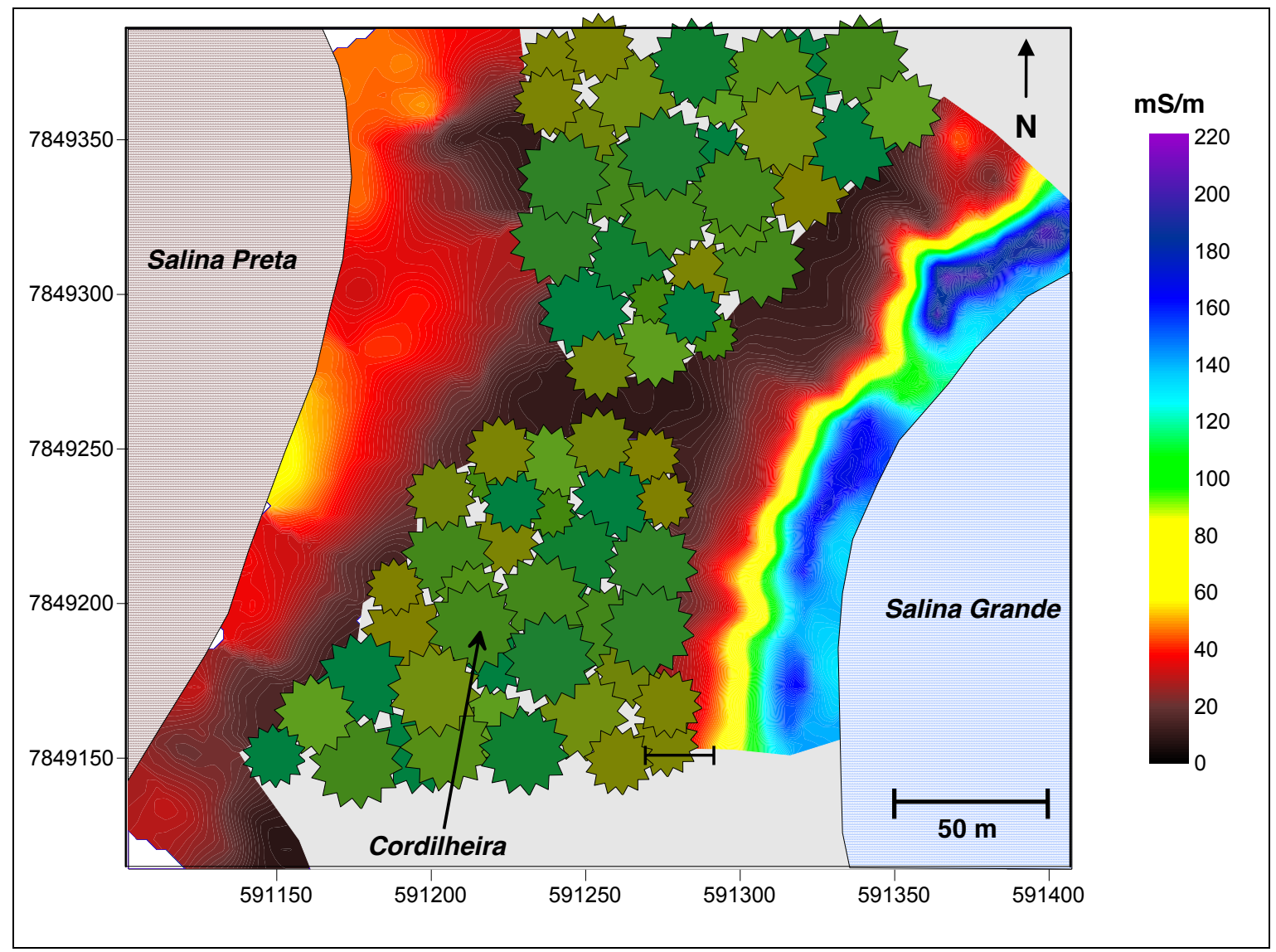

Figura 46. Mapeamento EM38-DMV entre a Salina Preta e a Salina Grande. Notar a diferença das respectivas gamas de condutividade elétrica aparente (CEa).

\subsubsection{Morfologia do Solo nas Salinas Grande e Preta}

A morfologia do solo foi estudada em uma sequência feita por tradagens e medidas de CEa com o EM31-DMV em modalidade vertical. Ela se inicia no limite da Salina Grande, atravessa a cordilheira e acaba no limite da Salina Preta. Esse corte tem 116 metros de comprimento, com um desnível de 4,40 m entre a Salina Grande e a parte mais alta da cordilheira, e de 3,32 m entre esta parte da cordilheira e a Salina Preta.

O perfil simplificado da cobertura pedológica, apresentado na Figura 47, mostra os horizontes arenosos superficiais, e seus contatos abruptos com o 
horizonte esverdeado endurecido, areno-argiloso profundo. $\mathrm{Na}$ cordilheira, este horizonte esverdeado é tão endurecido, que não permitiu a continuidade das tradagens.

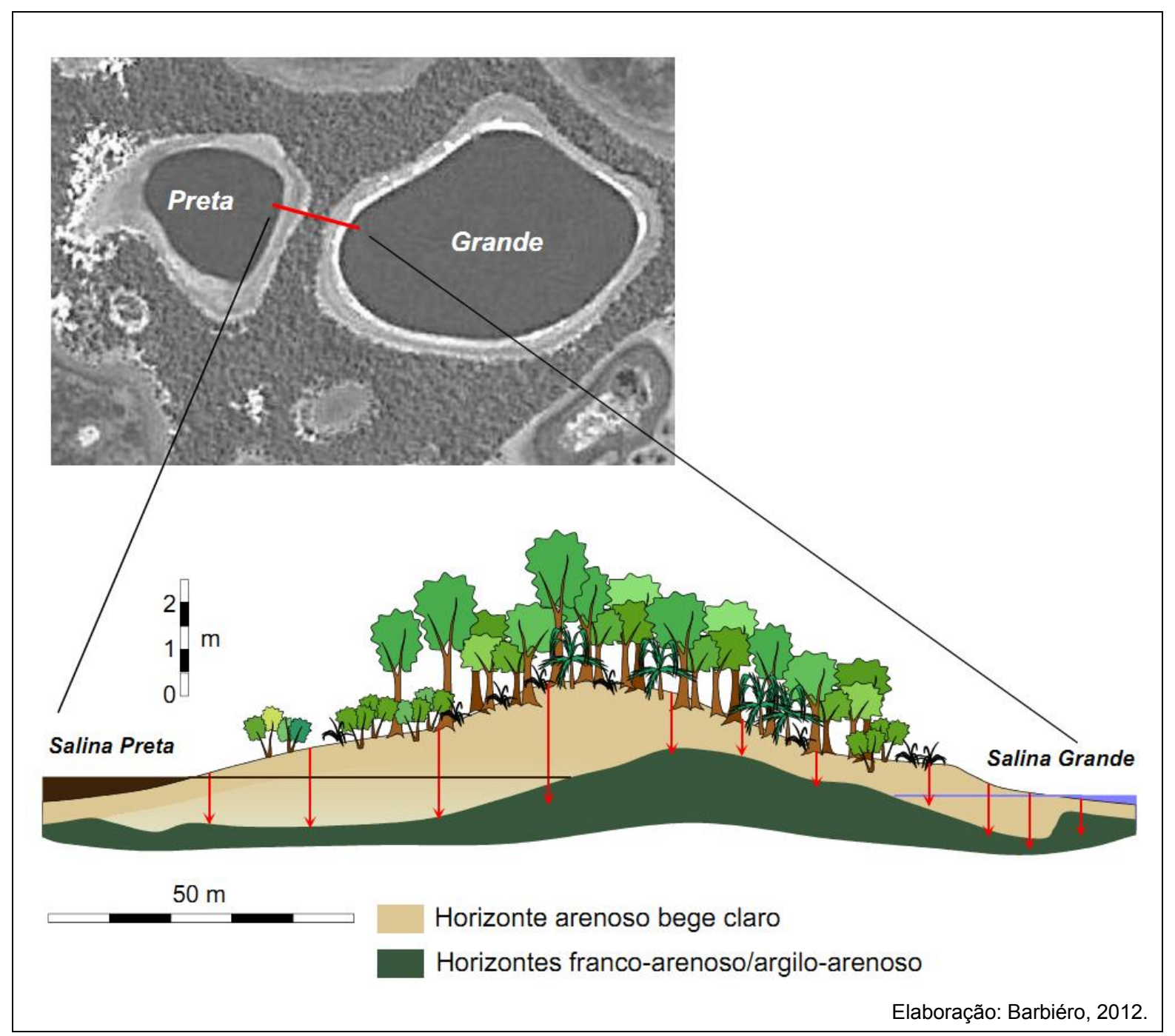

Figura 47. Sequência de solo passando pela cordilheira e ligando as Salinas Grande e Preta.

Em primeiro lugar, destaca-se a forma nitidamente ondulada do horizonte profundo, formando canaletas, mais acentuada do lado da Salina Grande do que do lado da Salina Preta. Além disto, nota-se também que o nível da água entre as salinas apresenta uma diferença de aproximadamente $1 \mathrm{~m}$ entre uma e outra, e isto em maio de 2010 quando o nível regional das águas estava estabilizado após alguns meses sem precipitações. O lençol freático entre as duas salinas se encontra 
separado por uma elevação do horizonte esverdeado endurecido, cujo topo está ligeiramente deslocado do ponto topográfico mais alto da cordilheira. Consequentemente, apesar da proximidade física essas duas salinas, provavelmente apresentam funcionamentos hidrológicos independentes.

\subsubsection{Salina $60 \mathrm{Mil}$}

A Figura 48 apresenta o mapeamento com o EM31-DMV realizado no período de seca ao redor da Salina 60 Mil, em que a água estava circunscrita apenas à sua porção mais arredondada. Destaca-se ao norte da salina uma mancha com valores de CEa superiores a $80 \mathrm{mS} / \mathrm{m}$, ligada à subida do horizonte (4) endurecido praticamente na superfície do solo. Pode-se dizer, portanto, que essa mancha corresponde ao setor (c), descontínuo, descrito ao redor da Salina Verde. Em geral, há na cordilheira uma diminuição dos valores de CEa, mas com ligeiros aumentos ligados às ondulações dos horizontes endurecidos profundos. O perfil da cobertura pedológica estudado confirma a forma ondulada do horizonte esverdeado profundo, argilo-arenoso endurecido, cujo contato com o conjunto de horizontes arenosos de superfície apresenta 4 ondulações nítidas, das quais as mais acentuadas se localizam nas proximidades da Salina 60 Mil. 


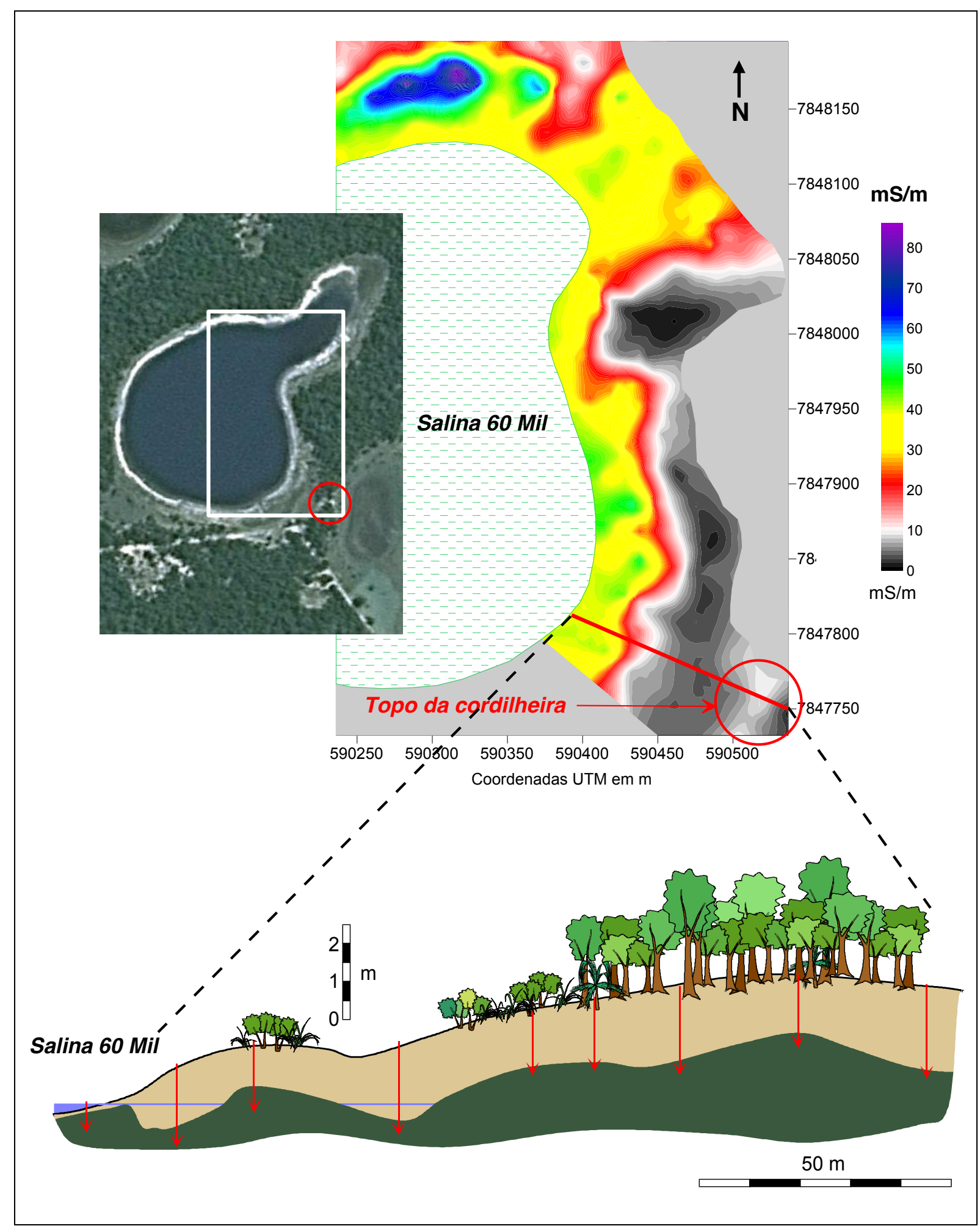

Figura 48. Mapeamento EM31-DMV e perfil de solo entre a cordilheira e a Salina 60 Mil. 


\section{DISCUSSÃO}

\subsection{Sistema representativo da Nhecolândia}

Os mapeamentos, em particular o apresentado na Figura 35, mostram que os valores de condutividade elétrica aparente (CEa) são organizados em faixas com forma de anéis, mais ou menos contínuos, ao redor das salinas. Os diferentes setores de CEa coincidem com as organizações verticais e laterais dos horizontes, suas profundidades e espessuras, e com a presença de água salina armazenada entre os horizontes sub-superficiais e profundos. Isto evidência que a distribuição da gama de CEa se faz em função das salinas, mas, sobretudo, que a própria cobertura pedológica se organiza ao redor das salinas. Estas observações parecem concordar com a hipótese de que a formação dos horizontes, sobretudo os profundos mais ou menos endurecidos, seja comandada por uma sedimentação química induzida pela presença de águas muito alcalinas das salinas.

A seguir serão apresentados elementos visando uma colocação mais pertinente dessa hipótese.

\subsubsection{Similaridades morfológicas}

A morfologia da sequência de solos estudada na Salina Verde apresenta grandes similaridades com a Salina do Meio descrita por Furquim (2007) na Fazenda Nhumirim. Esta se localiza a uma distância de $83 \mathrm{~km}$, em linha reta, da área de estudo do presente trabalho. A morfologia dos solos dessas duas salinas é apresentada na Figura 49.

As duas sequências se assemelham pelo tamanho, pela inclinação da topografia, pelas características morfológicas dos solos e pelas distribuições dos horizontes. 


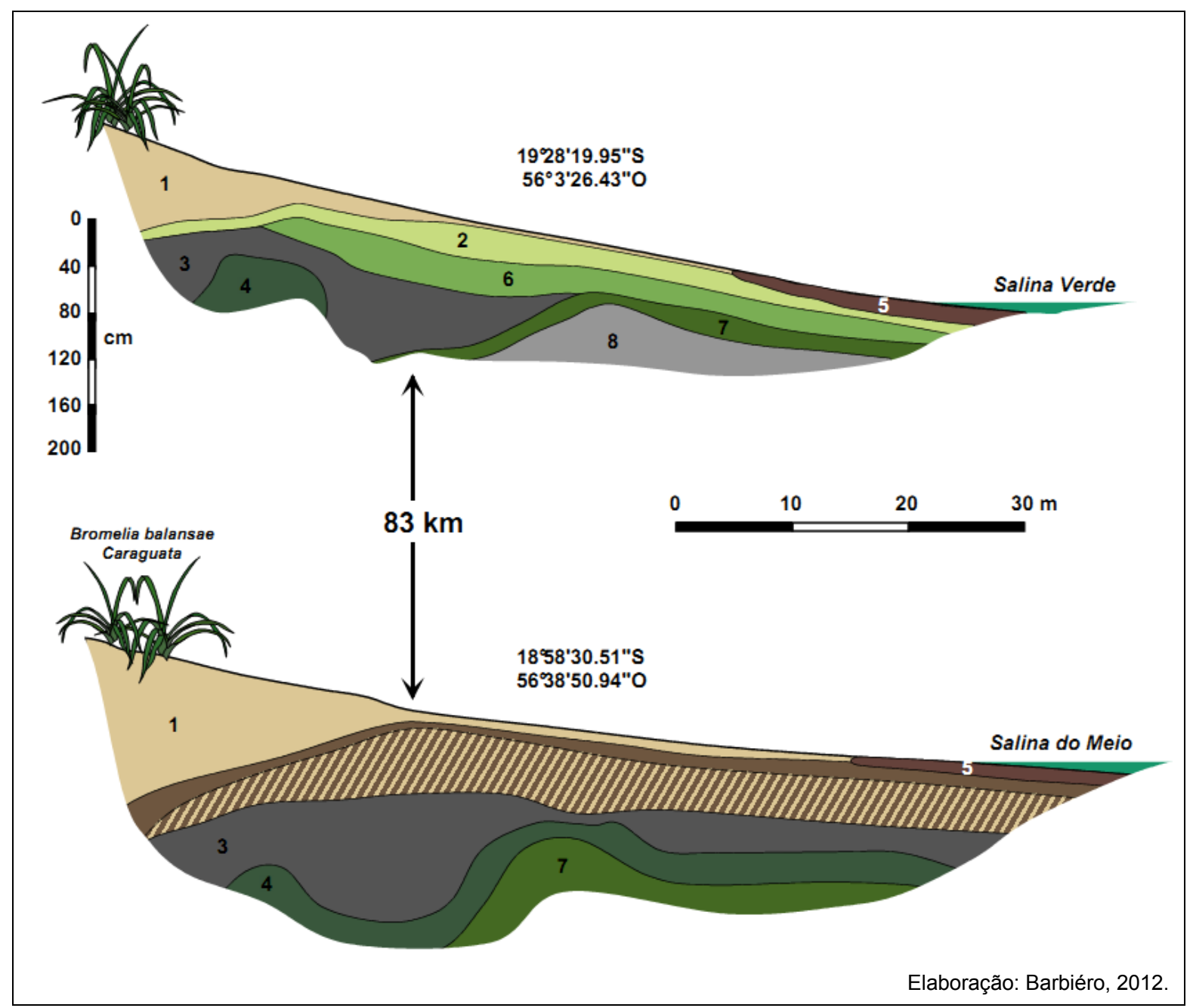

Figura 49. Comparação entre a morfologia dos solos na Salina Verde (presente trabalho) e na Salina do Meio (adaptada de Furquim, 2007).

Em primeiro lugar, os horizontes arenosos de superfície (1), (2) e (6) aparecem nas duas sequências. Contudo, na Salina do Meio os horizontes (2) e (6) não apresentam coloração verde dada pelas algas. Em segundo lugar, nota-se, em superfície, e na proximidade imediata da salina, a presença do horizonte orgânico escuro (5) mais extenso na Salina Verde que na Salina do Meio.

Em terceiro lugar, a sequência da Salina do Meio também se caracteriza por horizontes profundos endurecidos com forma ondulada, cujos limites superiores com os horizontes arenosos apresentam elevações semelhantes àquelas descritas na sequência da Salina Verde. 
Furquim (2007) e Furquim et al., (2010a) destacaram que a diferença entre os horizontes (4) e (7) recai no grau de cimentação pela sílica amorfa que cada um apresenta. Na Salina do Meio, o horizonte (4) endurecido se estende ao longo da sequência, e seu limite superior faz duas ondulações bem marcadas. Ao contrário, o horizonte (4) na Salina Verde se reduz a um volume individualizado, de algumas dezenas de metros situado no limite praia-cordilheira, com contato superior apresentando uma única ondulação. O horizonte (7) nesta salina é pouco endurecido, e logo abaixo dele aparece um horizonte cinza-claro arenoso (8), que não aparece na Salina do Meio. Lembrando que a base do horizonte (7) não pode ser atingida pelo trado manual na Salina do Meio dado o alto grau de cimentação desse horizonte.

Estas diferenças morfológicas são reforçadas pelas distribuições dos valores de $\mathrm{pH}$ nas duas sequências, como mostra a Figura 50. Enquanto na Salina do Meio os valores de $\mathrm{pH}$ acima de 10 praticamente generalizam-se ao conjunto dos horizontes, o $\mathrm{pH}$ na Salina Verde atinge o valor 10 somente em uma pequena zona circunscrita entre os topos dos horizontes (2) e (3), que se estende sobre o horizonte (7). A diminuição dos valores de $\mathrm{pH}$ em direção à base do perfil não foi observada na Salina do Meio.

Em síntese, a morfologia da cobertura pedológica da Salina Verde faz parte de um padrão morfológico comum na Nhecolândia, e isto provavelmente traduz presença dos mesmos tipos de constituintes e funcionamentos hidrológicos similares. Entretanto, é importante considerar as diferenças entre elas dadas, de um lado, pela abrangência espacial dos valores elevados de $\mathrm{pH}$, e de outro, pelo grau de cimentação dos horizontes profundos pela sílica amorfa, mais marcadas na Salina do Meio. Em decorrência disto, pode-se dizer que o processo de alcalinização 
dos solos, com aumento de $\mathrm{pH}$, é mais pronunciado na Salina do Meio que na Salina Verde.

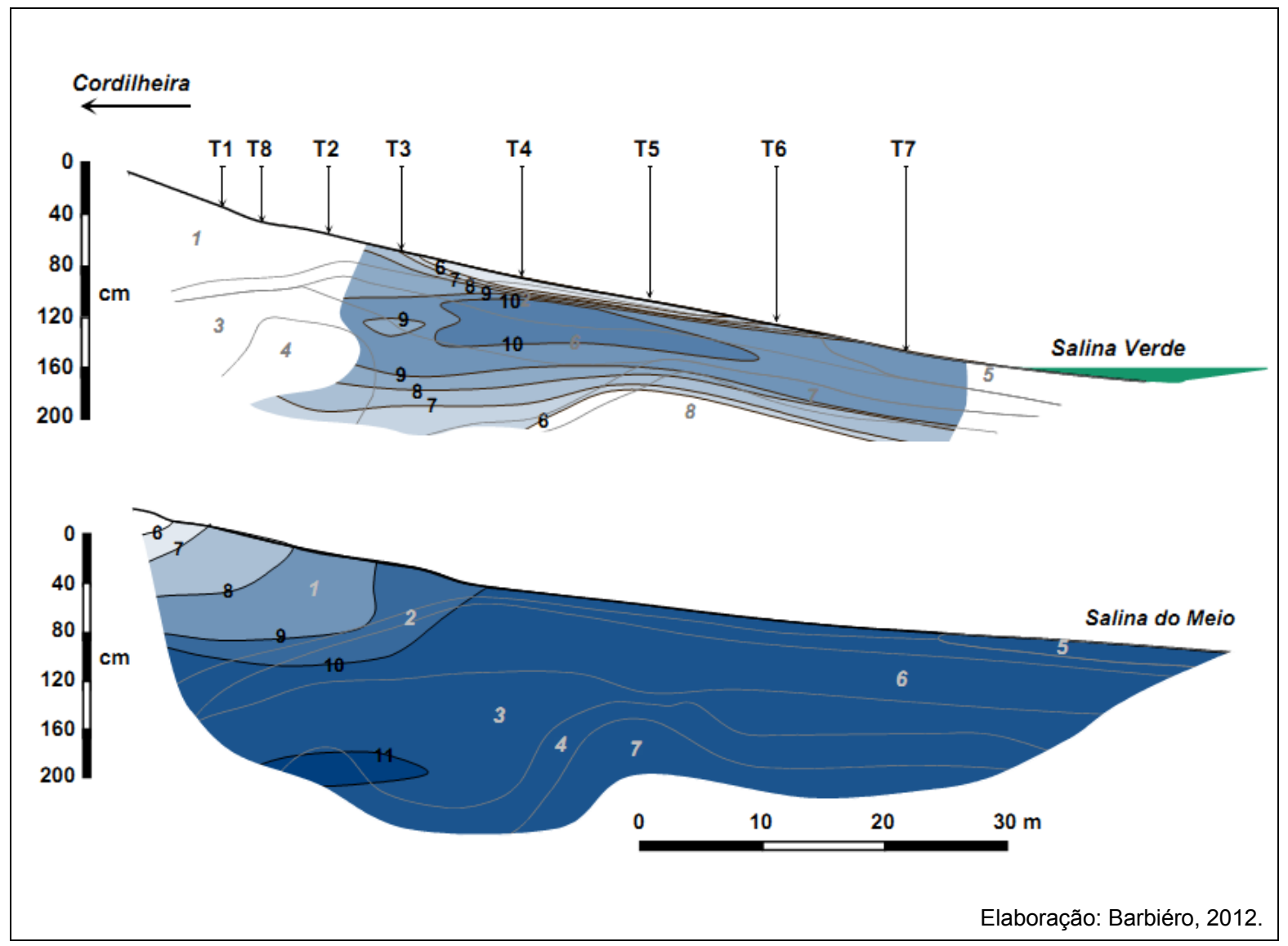

Figura 50. Distribuição do $\mathrm{pH}\left(\mathrm{H}_{2} \mathrm{O}\right)$ dos solos nas Salinas Verde e do Meio (esta adaptada de Furquim et al., 2010).

\subsubsection{Similaridades físico-químicas}

O mapeamento da Salina do Meio, realizado por indução eletromagnética EM38-DMV por Barbiéro et al., (2008), é apresentado na Figura 51 juntamente com o mapeamento da Salina Verde realizado no decorrer deste trabalho. Nota-se que a Salina do Meio é menor que a Salina Verde, porém apresentam, claramente, uma organização similar de distribuição dos valores de CEa. A gama de valores de CEa é de 20 a $220 \mathrm{mS} / \mathrm{m}$ em ambos os mapas. 


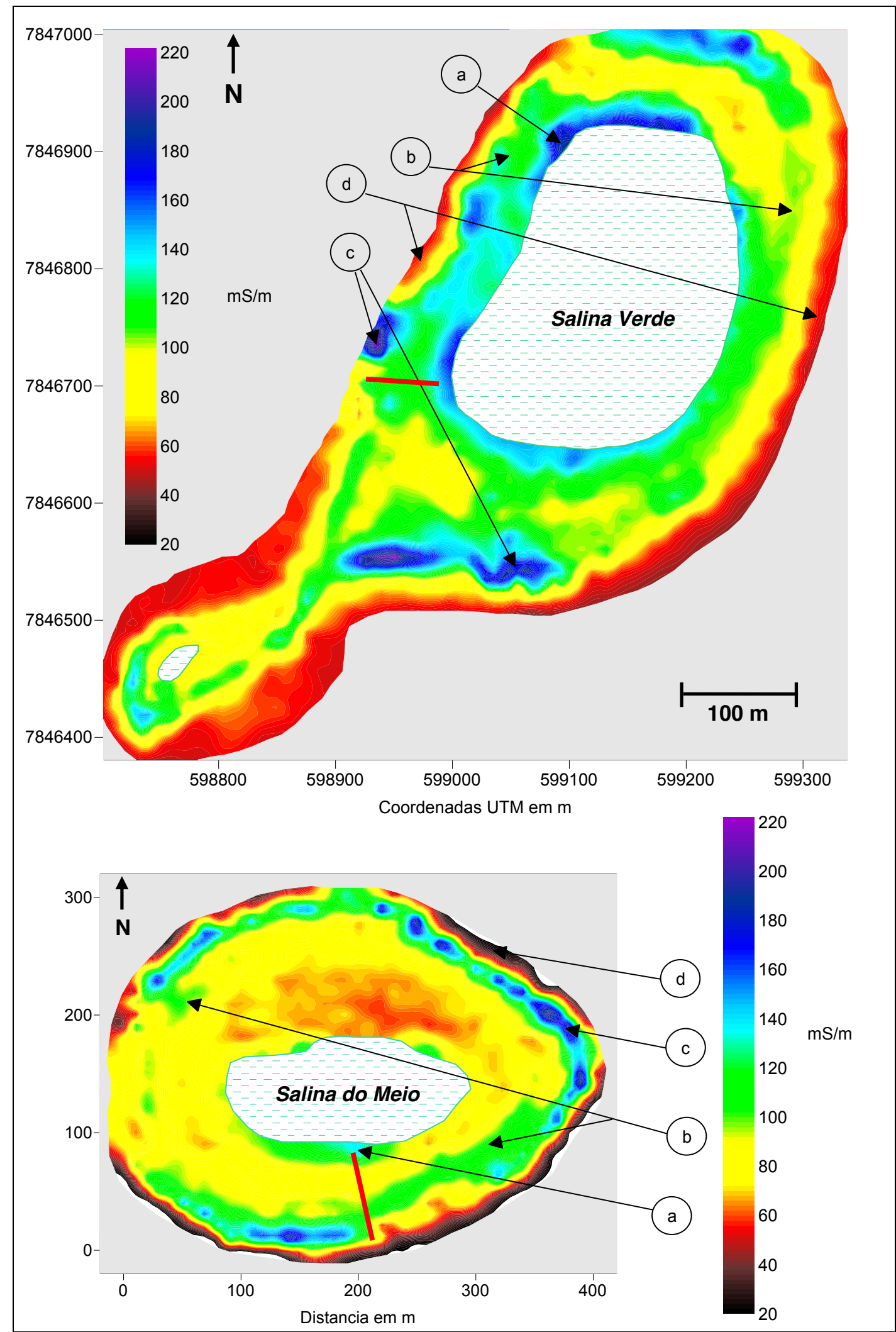

Figura 51. Mapas de distribuição dos valores de CEa ao redor das Salinas Verde e do Meio (este adaptado de Barbiéro et al., 2008).

O zoneamento da CEa por faixas em forma de anéis mais ou menos contínuos aparece ao redor das duas salinas, aqui denominados de setores. O setor 
(a) aparece na proximidade imediata das duas salinas, sendo muito mais desenvolvido na Verde que na do Meio, e em ambas está ligado ao horizonte orgânico (5) superficial. O setor (b) corresponde às goteiras formadas pelas ondulações do horizonte (4), onde se armazena uma água muito concentrada na Salina Verde, com alto valor de CE, na estação seca. O setor (c), pouco marcado no local onde foi posicionada a sequência de solos descrita por Furquim (2007), corresponde a uma subida do horizonte (4) na Salina Verde, e finalmente, nas duas, uma diminuição dos valores de CEa em direção à cordilheira que caracteriza o setor (d).

\subsubsection{Similaridades funcionais}

A morfologia dos solos na cordilheira se caracteriza por contatos abruptos entre os horizontes arenosos de superfície e os horizontes profundos, geralmente endurecidos, e com textura mais fina, franco-arenosa a argilo-arenosa (Figura 52). Esse contato também é nitidamente ondulado, e apresenta elevações que são ligeiramente deslocadas em relação ao ponto topográfico mais alto do centro da cordilheira. As sequências de solos estudadas entre as Salinas Grande e Preta, mas igualmente na cordilheira ao redor da Salina 60 Mil, também apresentam essa morfologia.

A morfologia dos solos da cordilheira que contorna a Salina do Meio também é marcada por elevações no contato dos dois conjuntos de horizontes, superficiais e profundos (Barbiéro et al., 2007). Nesta salina a infiltração da água diminui, aproximadamente, de $1 / 1000$ dos horizontes arenosos superficiais para os horizontes profundos argilo-arenosos endurecidos. Interessante lembrar que na 
Salina do Meio esses horizontes endurecidos apresentam grandes proporções de sódio no complexo de troca, e alto grau de cimentação pela sílica amorfa.

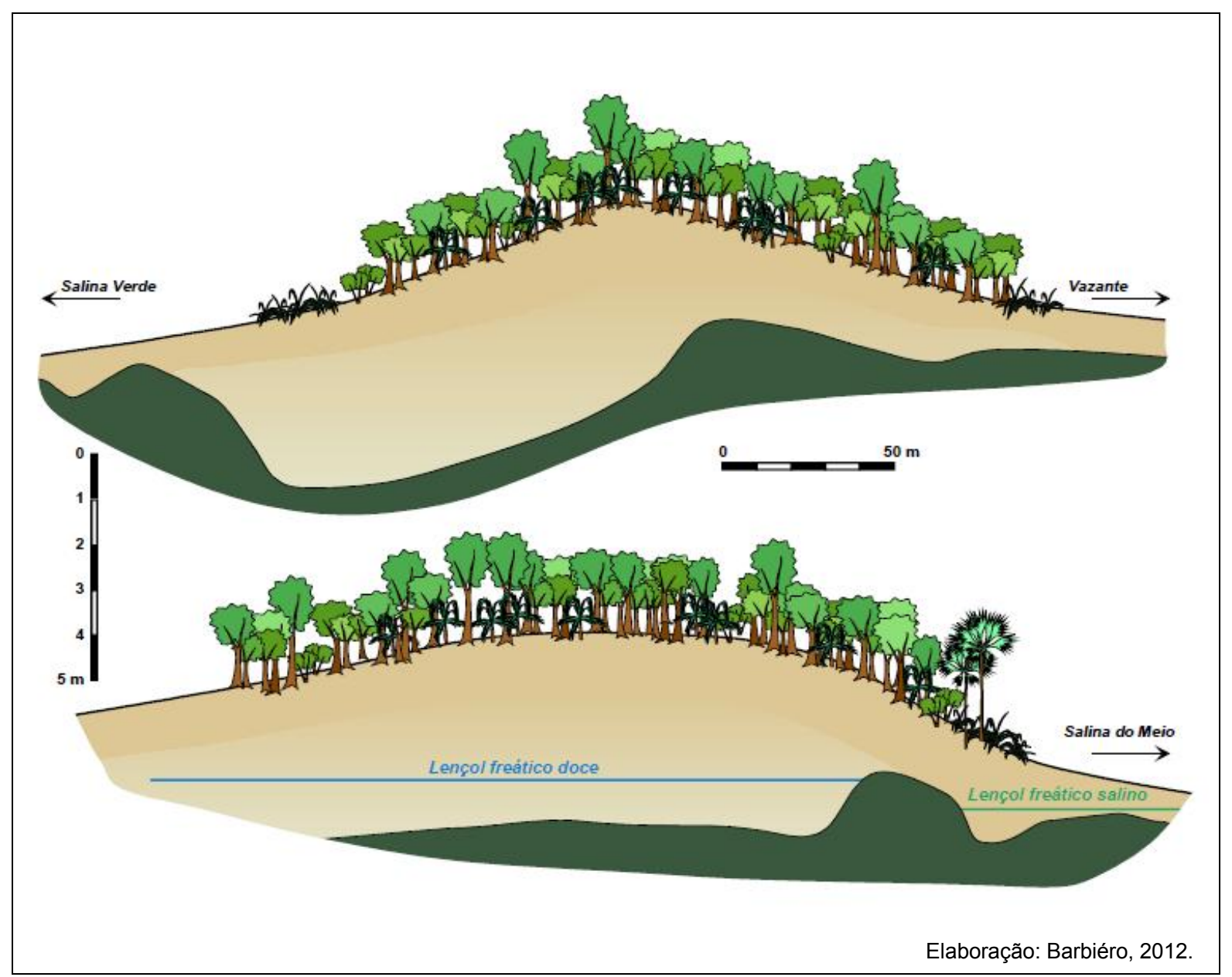

Figura 52. Morfologia de solos das cordilheiras contíguas às Salinas Verde e do Meio (esta adaptada de Barbiéro et al., 2008).

Em síntese, o contato entre esses horizontes é fundamental para entender a dinâmica subsuperficial da água, pois a diferença de potencial hidráulico que apresentam certamente governa os fluxos de água entre salinas e cordilheiras. Outro ponto importante a destacar é que na estação seca, a elevação do contato desses horizontes endurecidos fragmenta o lençol freático em dois segmentos, um de água doce na cordilheira, e outro de água salgada na salina (Barbiéro et al., 2008). No capítulo 4 essas questões serão retomadas. 


\section{CONSIDERAÇÕES GERAIS}

O segundo capítulo mostrou que o principal eixo de variabilidade química das águas é o grau de salinidade que apresentam, e que a variável condutividade elétrica (CE) das águas se inscreve no primeiro plano fatorial da ACP, que responde por aproximadamente $86 \%$ da variabilidade total da amostragem, o que é considerável.

Neste capítulo 3 destaca-se, em primeiro lugar, o fato de que, ao mesmo tempo, algumas salinas se concentram enquanto outras se diluem. Em outros termos, enquanto algumas salinas evoluem dentro de gamas muito elevadas de salinidade, outras evoluem dentro de gamas muito reduzidas.

Estes fatos indicam, ao menos na escala de três anos de observação deste trabalho, que a salinidade não responde simplesmente a uma concentração por evaporação ou a uma diluição por precipitações. Outros fatores devem intervir no comportamento da salinidade, sem que se possa, nesse estágio e neste trabalho, definir quais são. Voltaremos a estes aspectos no capítulo 4.

Um segundo ponto diz respeito à grande variabilidade das condições redox nos sedimentos das salinas, que deixa entrever tendências, isto é, condições mais anóxicas nas Salinas Verde e Grande, e mais óxicas na Salina Preta. Estes resultados podem ser melhor compreendidos se considerar-se as florações de cianobactérias que ocorrem nas Salinas Verde e Grande, mas não na Salina Preta. Essas algas produzem sazonalmente sedimentos orgânicos, cuja decomposição muito rápida contribui para abaixar o potencial redox nos sedimentos de fundo das salinas.

Alguns outros pontos foram avançados neste capítulo, e se referem ao perímetro das salinas. Os diferentes modos de prospecção, e suas combinações, 
são pertinentes para elaborar mapas detalhados da distribuição da Condutividade Elétrica Aparente (CEa) dos solos ao redor das salinas e nas cordilheiras. No presente trabalho, esses mapeamentos ressaltam o padrão morfológico da distribuição dos valores de CEa, em faixas anelares, mais ou menos contínuas, ao redor das salinas. Essas faixas, denominadas de setores, concordam com a morfologia da cobertura pedológica, que se repete, de maneira mais ou menos completa, nos diferentes sítios estudados.

Destaca-se, igualmente, a similaridade morfológica da cobertura pedológica ao redor das salinas estudadas neste trabalho, e destas com a de outra localizada a uns 83 km de distância, na porção oeste da Nhecolândia. Isso coloca em evidência que a cobertura pedológica apresenta um padrão morfológico regional, e confirma que os exemplos estudados neste trabalho são representativos da Nhecolândia.

Nessa morfologia de solos, que se repete de um sítio para outro, dois aspectos chamam a atenção:

$\left.1^{\circ}\right)$ Se assumimos os resultados dos estudos geoestatísticos apresentados no capítulo 2, o processo que controla o grau de salinidade das águas se situa num raio de aproximadamente 200 m, a partir da borda das salinas. Esta distância indica, necessariamente, a cordilheira, onde se observa uma elevação do contato entre os horizontes arenosos permeáveis, de superfície, e os horizontes profundos francoarenosos a argilo-arenosos endurecidos, e pouco permeáveis.

$\left.2^{\circ}\right)$ No interior da cobertura pedológica ao redor das salinas existe, localmente, um estoque de águas hipersalinas, que podem ser remobilizadas a qualquer momento.

Estes dois aspectos guiaram os trabalhos que serão apresentados no próximo capítulo. 


\section{CAPÍTULO IV}

FUNCIONAMENTO HIDROLÓGICO E TIPOLOGIA DE

SALINAS 
Este capítulo será dedicado a uma síntese das informações obtidas sobre a variabilidade da composição química das águas, e sobre os sistemas pedológicos ao redor das salinas. Estes dois aspectos têm representatividade regional, conforme se mostrou nos capítulos anteriores, e afetam o funcionamento atual das salinas. Para isto, serão retomadas informações geradas em pesquisas anteriormente desenvolvidas na Nhecolândia.

O objetivo é, de um lado, tentar elaborar um modelo de funcionamento hidrológico das salinas baseado no conjunto de observações realizadas até agora nessa área; e de outro, identificar parâmetros que neste trabalho possibilitem esboçar uma tipologia de salinas, ao menos para os exemplares aqui estudados.

\section{MODELO DE FUNCIONAMENTO HIDROLÓGICO}

A Nhecolândia é alimentada principalmente pelas águas do Rio Taquari, cujo perfil químico se caracteriza por uma alcalinidade residual calcita positiva (Rezende Filho, 2011; Rezende Filho et al., 2012, no prelo). Nesse perfil, os teores em alcalinidade são sempre mais elevados que os teores em cálcio, comum nas águas que drenam rochas graníticas e areníticas, como é o caso da Bacia do Taquari na Bacia do Alto Paraguai (Rezende Filho et al., 2012, no prelo).

Nesse contexto, se as águas são submetidas a uma concentração por evaporação, elas evoluem numa via alcalina sódica (Valles et al., 1991), que é

acompanhada, de um lado, por um controle do $\mathrm{Ca}^{2+}$ e do $\mathrm{Mg}^{2+}$, e de outro, por um aumento da alcalinidade e do pH, e nos estágios finais, por uma solubilização da sílica. Este é exatamente o contexto geoquímico identificado na Nhecolândia (Barbiéro et al., 2002, 2008, Furquim, 2007; Rezende Filho, 2011). 
A concentração das águas pelo processo de evaporação é muito comum, característico de climas secos e áridos, onde as chuvas são limitadas, com taxas de evaporação que excedem as de precipitação. Este é o caso, por exemplo, do grande Rift Africano onde foram descritos numerosos lagos alcalinos (Wood e Talling, 1988), ou do Delta do Okavango, mencionados no Capítulo 1.

No Pantanal da Nhecolândia, as taxas anuais de evaporação são moderadas da ordem de 1400 mm, embora excedam as de precipitação anual, de 1100 mm. Contudo, essas condições não são suficientes nem para acumular nem para manter sais na paisagem.

A questão que se coloca é dupla, pois se trata de compreender: $\left(1^{\circ}\right)$ como lagoas submetidas a essas condições podem apresentar graus de salinidade tão elevados (?), e $\left(2^{\circ}\right)$ como lagoas tão próximas umas das outras, de 120 a $150 \mathrm{~m}$, e submetidas às mesmas condições climáticas, podem apresentar graus tão diferentes, muito alto e muito baixo, de salinidade (?).

Ainda não existem respostas satisfatórias para isto, mas talvez elas possam ser buscadas nos regimes hidrológicos das lagoas, que veremos a seguir.

\subsection{Funcionamento hidrológico da Salina do Meio}

Com base em um monitoramento piezométrico de 3 anos foi proposto um modelo de funcionamento hidrológico da Salina do Meio, visando explicar a acumulação de elementos químicos, e a salinidade (Barbiéro et al., 2007, 2008). Esse modelo se baseia na presença de uma soleira, identificada na cobertura pedológica da cordilheira, que determina os fluxos das águas sub-superficiais em direção à salina (Figura 53). 


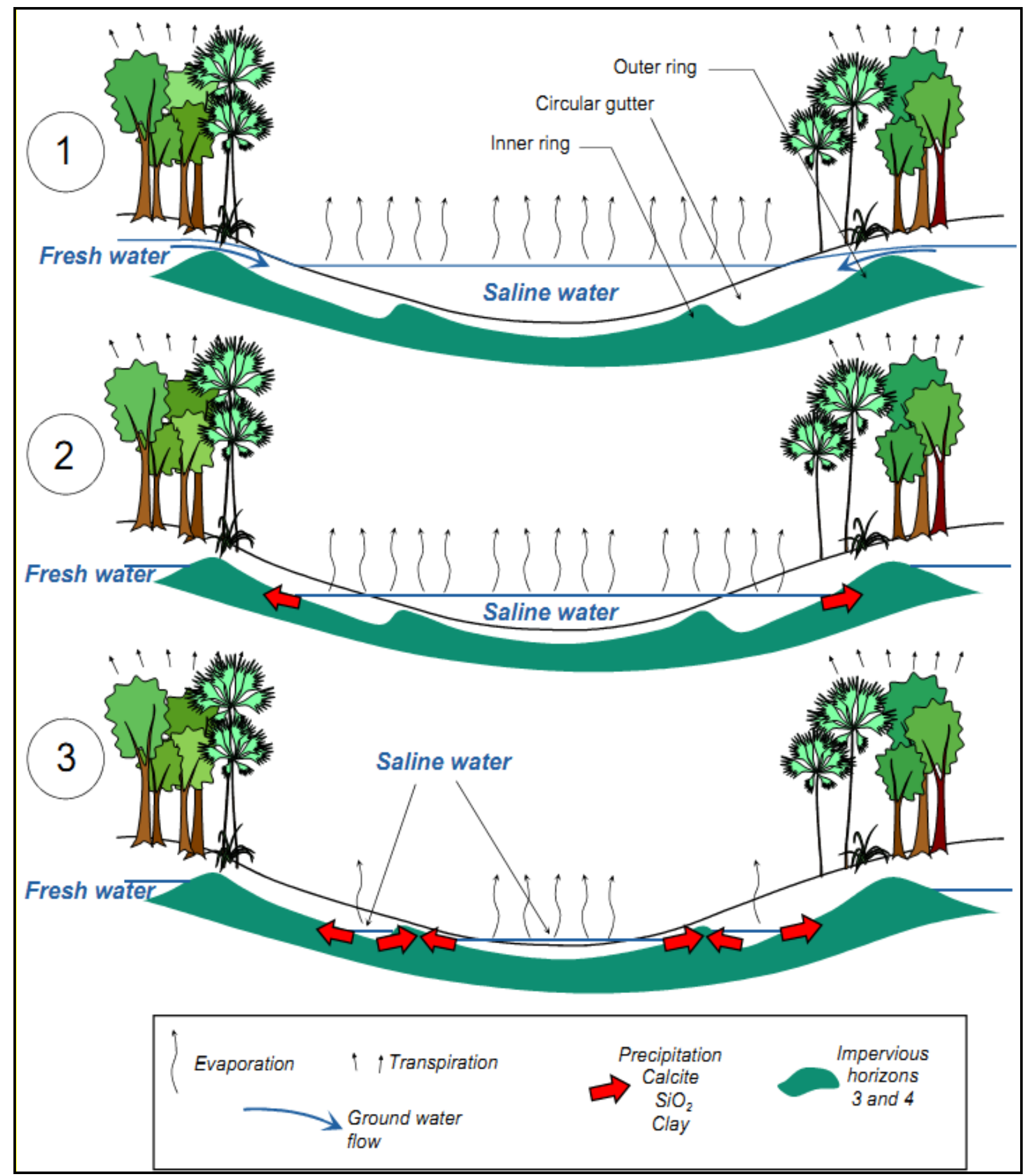

Figura 53. Modelo de funcionamento hidrológico da salina e gênese das ondulações dos horizontes profundos endurecidos (adaptado de Barbiéro et al., 2008).

Na estação úmida, a altura do nível da água no Pantanal se eleva rapidamente. As salinas da Nhecolândia também são submetidas a esse aumento do nível da água regional, mas basicamente da água sub-superficial. Quando o nível da água do lençol sobe e ultrapassa a soleira, formada pelas elevações dos 
horizontes profundos endurecidos, a água escoa da cordilheira em direção à salina, onde fica retida e da qual só pode sair por evaporação (Figura 53). Na estação seca, ao contrário, quando o nível da água abaixa, a soleira fragmenta o lençol freático, que passa a funcionar em dois segmentos independentes, um de água doce ligado à cordilheira, e outro de água salgada ligado à salina (Figura 53-2). A soleira desconecta as águas, e impede que a água salgada da salina aflua no lençol de água doce na cordilheira (Barbiéro et al., 2007; 2008). Portanto, a soleira isola, em porções restritas da paisagem, as águas salgadas, mas também as próprias salinas (Figura 53).

Estes autores relacionaram esse modelo de funcionamento hidrológico à gênese da cobertura pedológica ao redor das salinas, sobretudo da forma ondulada dos horizontes profundos, areno-argilosos endurecidos. Na estação úmida e início da seca, o nível da água na salina é alto, e favorece a neoformação de argila na cordilheira, ou no limite cordilheira-praia na salina (Figura 53-2). Após ruptura do lençol freático pela soleira, o nível da água na salina começa a descer, principalmente por evaporação, favorecendo a neoformação de argila na porção da praia contígua à salina.

Os movimentos do lençol e as oscilações da altura da lâmina da água na própria salina respondem, provavelmente, pelo desenvolvimento da forma ondulada dos horizontes profundos, endurecidos por cimento silicoso (Figura 53-3).

\subsection{Abrangência do modelo}

O modelo acima descrito se aplica ao funcionamento hidrológico da Salina do Meio. Contudo, também pode ser aplicado a outras salinas da Nhecolândia considerando-se a similaridade morfológica da cobertura pedológica que 
apresentam. Segundo esse modelo, percebe-se que a entrada de água na salina se faz unicamente pela chuva, e pela quantidade de água do lençol freático que a cada ano ultrapassa a soleira (Figura 54).

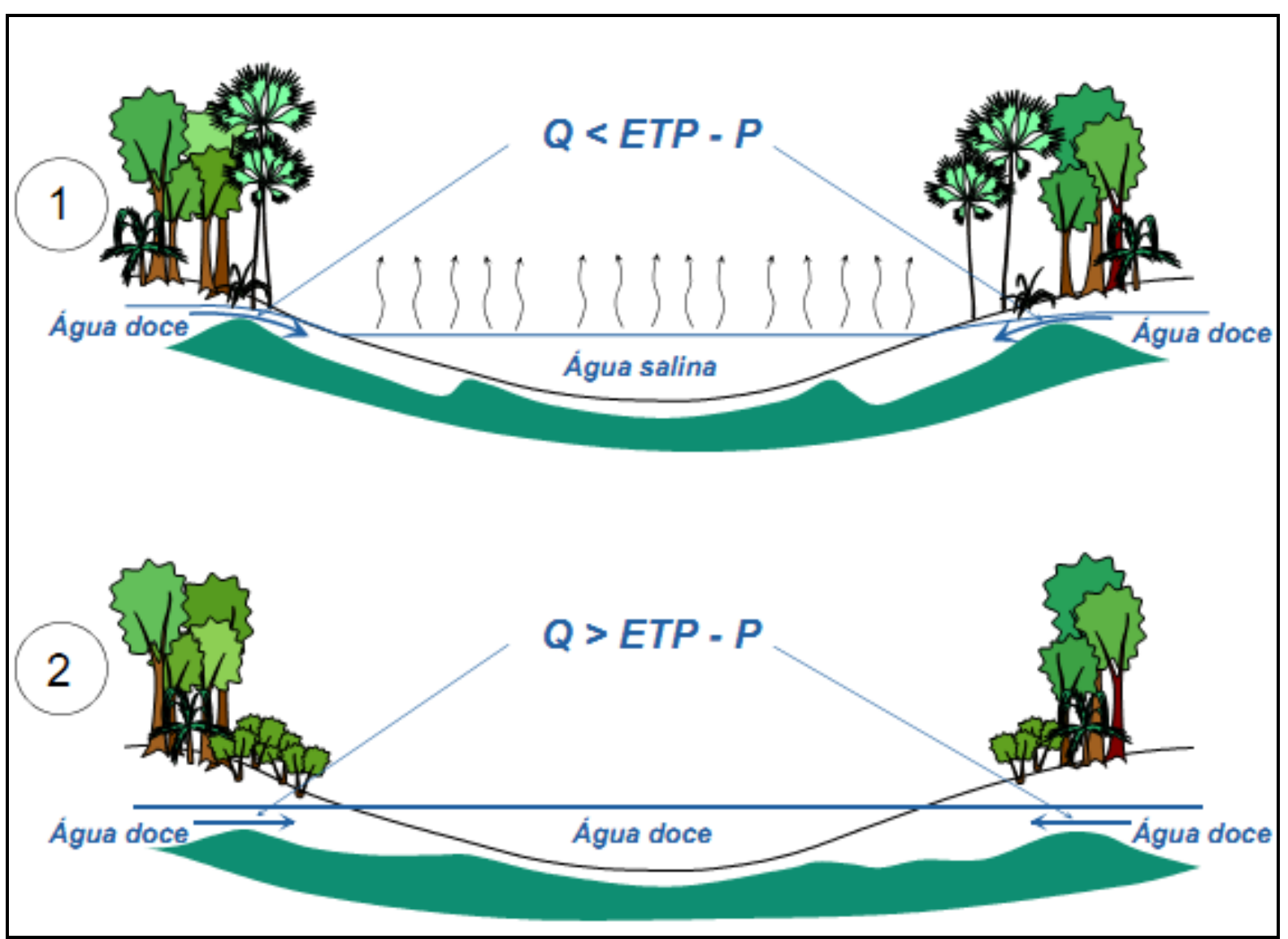

Figura 54. Modelo de funcionamento hidrológico em função da altura da soleira (Q: Volume anual de água que atravessa a soleira, ETP: Evapotranspiração anual, P: Precipitação anual).

Deste modo, ao ultrapassar a soleira, uma fração da água do lençol freático escoa em direção às depressões das lagoas. A quantidade média de água que flui por ano (Q) vai depender da altura da soleira, e da altura do nível freático regional. Portanto, (Q) diminui com o aumento da altura da soleira. Levando-se em conta isto, duas situações podem ocorrer:

(1) se $(Q<$ ETP-P) o grau de salinidade da lagoa aumenta a cada ano (Figura 54-1); 
(2) se $(Q>E T P-P)$ a cada ano a lagoa recebe água doce do lençol freático e a salinidade é mantida em níveis baixos (Figura 54-2).

Este esquema descreve um funcionamento de médio a longo prazos, pois a água da salina pode ser diluída nos anos de enchentes excepcionais.

\subsection{Adequação do modelo de funcionamento aos dados coletados}

O funcionamento hidrológico acima descrito explica como lagoas sujeitas a taxas anuais similares de evaporação e precipitação podem apresentar diferentes graus de concentração de íons dissolvidos (TDS). Como se trata de um processo que é acumulativo no tempo, esse funcionamento explica, satisfatoriamente, a amplitude da gama de salinidade observada na Nhecolândia.

Esse modelo é concordante com a distribuição bimodal da condutividade elétrica medida em 307 lagoas (Figura 55). Lembrando-se que a primeira moda corresponde às águas pouco concentradas, a hipótese é que elas provêm de lagoas onde a forma ondulada do horizonte profundo endurecido é pouco desenvolvida, ou seja, onde as soleiras são ou muito baixas, ou inexistentes. Neste caso, os fluxos de entrada de água sub-superficial são superiores às taxas de evaporação $(Q>E T P$ P). Por sua vez, a segunda moda corresponde às águas que se concentram de ano em ano. Neste caso, os fluxos de entrada de água sub-superficial são reduzidos pela altura da soleira, e, portanto, inferiores às taxas de evaporação $(\mathrm{Q}<\mathrm{ETP}-\mathrm{P})$. 


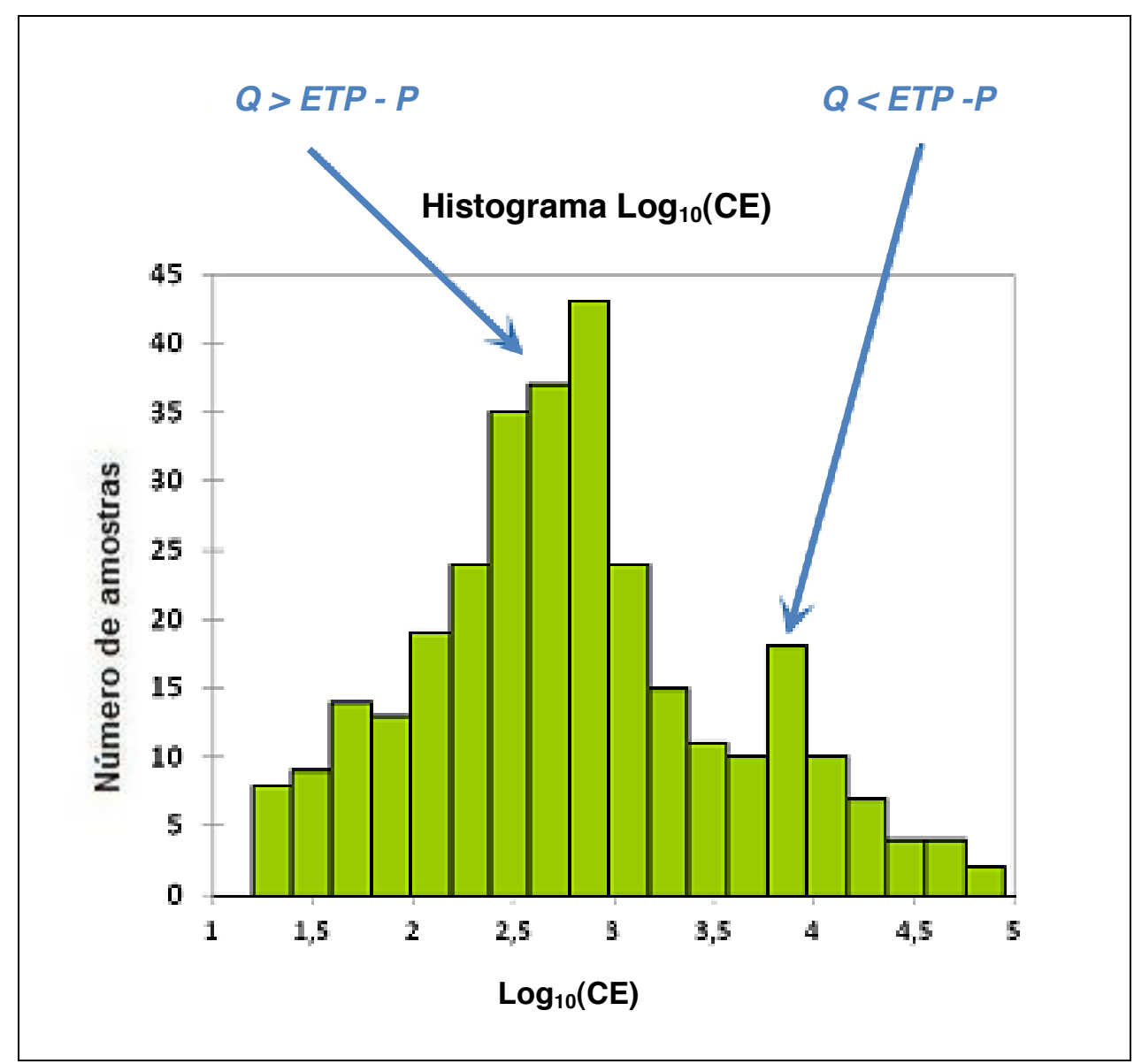

Figura 55. Modelo de funcionamento hidrológico de salinas e distribuição do $\log _{10}(C E)$.

Além da morfologia do solo, as variações anuais das taxas de precipitação, que definem a amplitude das cheias ao longo do tempo, igualmente contribuem para o funcionamento desse modelo. Há anos em que a elevação do nível regional das águas só é suficiente para ultrapassar certas faixas de altura de soleiras. Nesse caso, apenas serão diluídas as águas de lagoas com soleiras dentro desse limite de altura. Ao contrário, lagoas nas quais a altura da soleira esteja fora dessa faixa, suas águas serão submetidas a uma concentração. Esse funcionamento define estruturas em patamares, ou limiares, e respondem porque, em um mesmo período e com as mesmas condições climáticas, as águas de algumas lagoas se diluem, e a de outras se concentram. Estes fatos também foram observados nas áreas experimentais trabalhadas nesta pesquisa. 
Deste modo, um único tipo de água, evoluindo em uma via alcalina, sujeita a ciclos de concentração e diluição, pode explicar a relação observada entre pH e CE, mas também o fato de lagoas situadas tão próximas umas das outras apresentarem graus de mineralização, ou concentração, tão diferentes.

Em síntese, percebe-se que o controle do grau de salinidade das águas ocorre localmente, pois depende da presença, e sobretudo, da altura das soleiras, e isto vem corroborar os pequenos valores do alcance, de cerca de $200 \mathrm{~m}$, da variável $\log _{10}(\mathrm{CE})$ mostrado pelo variograma (Figura 21).

O modelo de funcionamento hidrológico proposto pelos autores (Barbiéro et al., 2008) para a Salina do Meio, também pode ser aplicado para as salinas estudadas neste trabalho, e explica, qualitativamente, o conjunto de observações e de medidas efetuadas no decorrer desta pesquisa. Na segunda parte deste capítulo, e a partir de um estudo de caso, esse modelo será testado para explicar a dinâmica sazonal da salinidade.

\section{FUNCIONAMENTO SAZONAL DA SALINA VERDE}

Este item apresenta o monitoramento da Salina Verde durante um ano hidrológico.

\subsection{Monitoramento, aquisição e tratamento dos dados}

Esse estudo teve por base a instalação, na parte mais profunda da Salina Verde, de uma sonda modelo «CTD Diver ${ }^{\circledR}$ » (Schlumberger Water Service) no final da estação seca, em setembro de 2010. As coordenadas UTM desse ponto são 529061 W e 7847050 S, Zona 21. Esse modelo de sonda permite monitorar três parâmetros ao mesmo tempo: 1) $(P)$ = Pressão exercida na sonda, que é a soma da 
pressão barométrica mais a pressão da coluna de água sobre a sonda; 2) (T em $\left.{ }^{\circ} \mathrm{C}\right)=$ Temperatura e, 3$)\left(\mathrm{CE}\right.$ em $\left.\mathrm{mS} \cdot \mathrm{cm}^{-1}\right)=$ Condutividade Elétrica da água.

Para obter $(P)$, que equivale às variações do nível da lâmina da água na salina, recorreu-se a medidas das variações da pressão barométrica. Com este fim, instalou-se na Fazenda Embiaria uma segunda sonda, modelo « Baro Diver $®$ », no ponto com Coordenadas UTM 598173,63 W e 7840040,81 S, Zona 21. Essa sonda foi instalada na cordilheira, em local sombreado, dentro de um tubo de PVC colocado a 1,20 m de profundidade no solo, a fim de protegê-la das variações de temperatura (Figura 56).

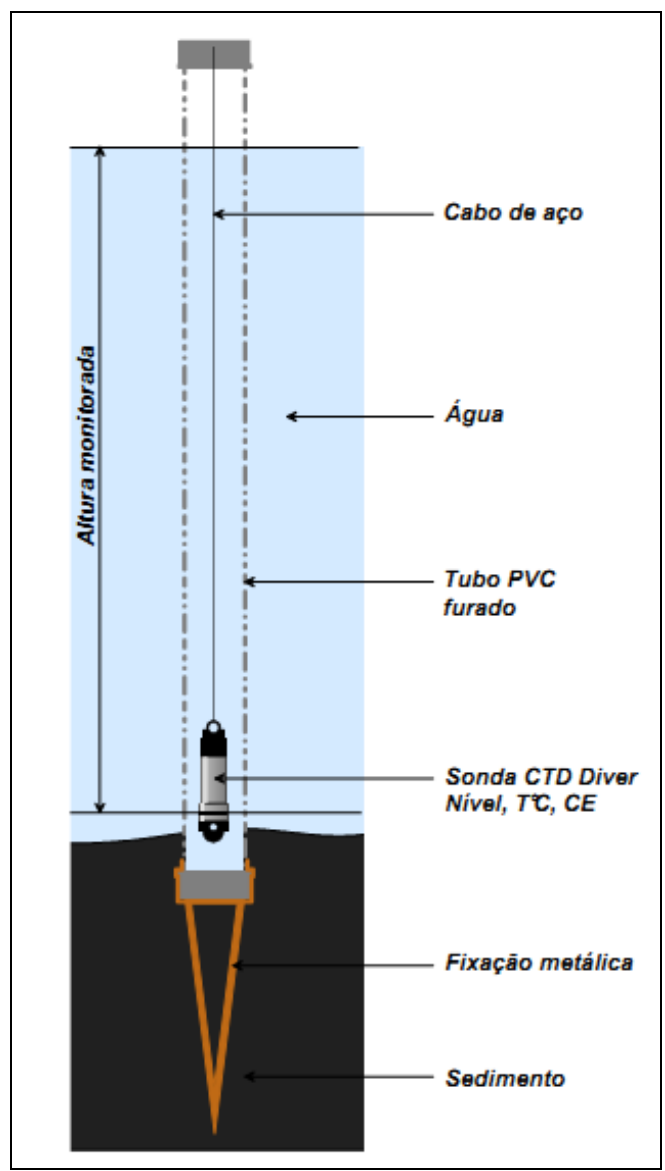

Figura 56. Ilustração da sonda protegida dentro de cano PVC instalada na Salina Verde.

As duas sondas foram programadas para aquisição automática de dados, a cada 3 horas, durante o período setembro de 2010 a outubro/2011, ou seja, durante 
um ano hidrológico completo. As variações da altura da coluna de água sobre a sonda foram obtidas subtraindo-se a pressão atmosférica da pressão total $(P)$ registrada pela sonda.
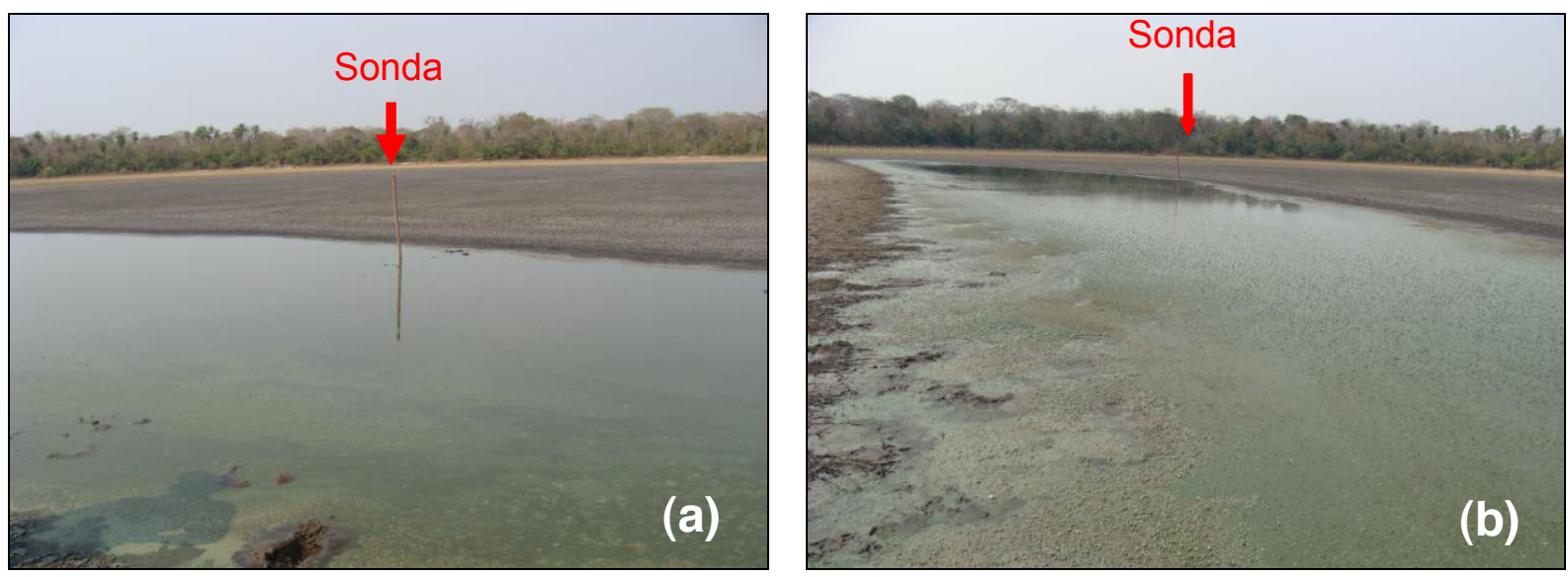

Foto 10. (a) e (b) Sonda instalada na Salina Verde no final da estação seca (Setembro/2010).
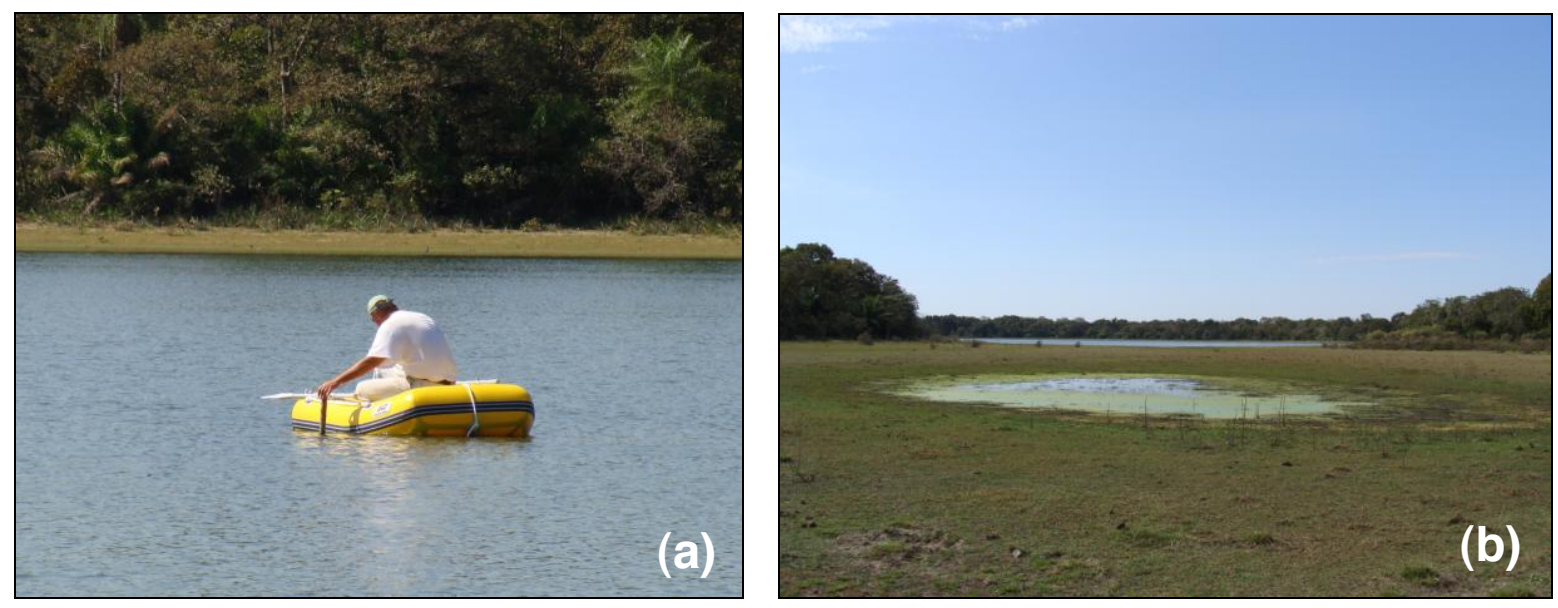

Foto 11. (a) Retirada da sonda para leitura dos dados, (b) divertículo da Salina Verde (visão sentido SW-NE) após grande cheia (Julho/2011).

\subsection{Resultados do monitoramento da água}

Os dados de condutividade elétrica e do nível da água na Salina Verde estão apresentados na Figura 57. O contexto meteorológico do período de monitoramento foi bastante peculiar. Instalou-se a sonda após dois anos particularmente secos, seguidos de uma estação chuvosa muito intensa em 2011, que abrangeu o ano de 
monitoramento. Nesse ano, a temperatura variou de $20,5^{\circ} \mathrm{C}$ a $31^{\circ} \mathrm{C}$, a condutividade elétrica da água de $16.000 \mu \mathrm{S} . \mathrm{cm}^{-1}$ a $500 \mu \mathrm{S} . \mathrm{cm}^{-1}$, e o nível da água da salina de 25 a $225 \mathrm{~cm}$.

No início do monitoramento, em setembro de 2010, o grau de salinidade da água era elevado, de $16.000 \mu \mathrm{S} . \mathrm{cm}^{-1}$. No final da estação seca, as primeiras chuvas provocaram, simultaneamente, uma subida do nível da água, uma diminuição da temperatura, e a condutividade elétrica (CE) passou, em apenas 15 dias, de 16.000 $\mu$ S.cm ${ }^{-1}$ para $11.000 \mu S . \mathrm{cm}^{-1}$. Em seguida, e no início de outubro, a CE volta a subir, com picos oscilando entre 13.500 e $11.500 \mu{\mathrm{S} . \mathrm{cm}^{-1}}^{-}$, e até final de outubro estaciona ao redor de $13.000 \mu \mathrm{S} . \mathrm{cm}^{-1}$, quando se instala a estação chuvosa. O nível de água na salina, até então muito baixo, começa a elevar-se.

Nota-se, em novembro, uma queda abrupta nos valores de CE, que

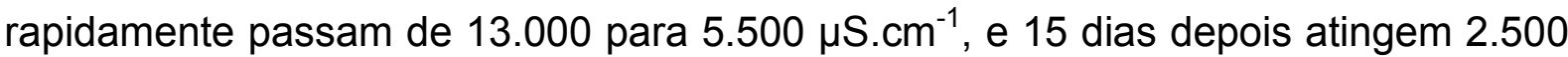
$\mu S . \mathrm{cm}^{-1}$. Esta diminuição dos valores de CE é acompanhada de uma subida do nível da água na salina, que passa, também em alguns dias, de 40 a $60 \mathrm{~cm}$. Porém, logo após essa queda, os valores de CE voltam rapidamente a subir, e atingem 12.000 $\mu S . \mathrm{cm}^{-1}$, e se mantém com pequenas oscilações nessa faixa de valores até quase o final de dezembro de 2010. A partir do início de janeiro de 2011 , os valores de CE começam novamente a diminuir de maneira abrupta, pois em apenas 2 dias passam de $12.000 \mu$ S. $\mathrm{cm}^{-1}$ para $2.000 \mu$ S. $\mathrm{cm}^{-1}$. 


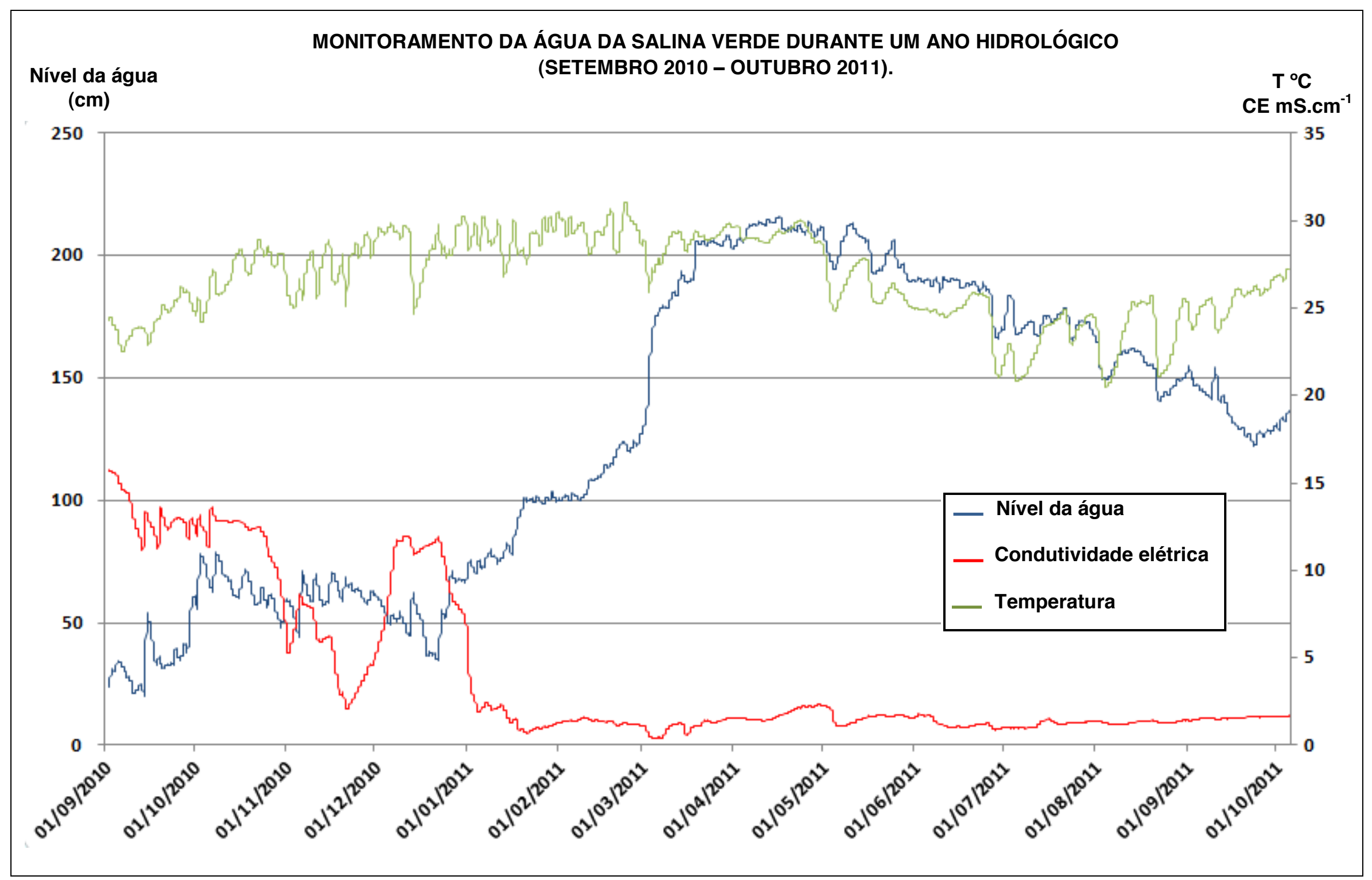

Figura 57. Dados do monitoramento durante um ano hidrológico na Salinas Verde de setembro/2010 a outubro/2011. 
Nesse intervalo de tempo, o nível da água na Salina não apresenta aumentos significativos, mas a partir quase do final de dezembro/10 começa a subir, concomitante a uma diminuição dos valores de CE. Em detalhe, nota-se que a chuva de 10 de dezembro marca um ligeiro decréscimo nos valores de CE, acompanhado de uma subida do nível da água e de uma diminuição da temperatura. Porém, a partir de fevereiro de 2011, a CE se instala na faixa entre 500 e $2000 \mu{\mathrm{S} . \mathrm{cm}^{-1}}^{\text {e aí }}$ permanece até o final do monitoramento.

A expressiva elevação do nível de água na Salina Verde, a partir de janeiro até metade de março de 2011, está ligada aos altos índices pluviométricos desses meses, que somados chegam a um total de $1377 \mathrm{~mm}$. Somente os $671 \mathrm{~mm}$ de precipitação ocorridos em março correspondem a aproximadamente $50 \%$ desse total, sendo que o mês de janeiro contribuiu com $347 \mathrm{~mm}$, fevereiro com $254 \mathrm{~mm}$, e abril com $105 \mathrm{~mm}$. Nesse período, o nível da água na Salina passou de 60 a 210 $\mathrm{cm}$.

Percebe-se, que apesar de algumas chuvas a estação úmida começou, efetivamente, apenas a partir de 20 de dezembro de 2010, e o gráfico mostra uma resposta significativa do nível da água na salina, que aumenta, e uma diminuição nítida da condutividade elétrica da água, cujos valores vão se estabilizar em torno de $2000 \mu \mathrm{S} . \mathrm{cm}^{-1}$.

A partir de maio, instala-se a estação seca e o nível da água na salina começa progressivamente a diminuir, e a condutividade elétrica da água apresenta um pequeno aumento no final de setembro de 2011. Nota-se, entretanto, que no período final do monitoramento o nível da água na salina diminuiu em pequenos patamares, mas não voltou ao nível inicial, mantendo-se cerca de $100 \mathrm{~cm}$ acima do nível registrado no início do monitoramento, em setembro de 2010. 


\subsection{Discussão dos resultados}

Globalmente, o monitoramento da CE, do nível e da temperatura da água na Salina Verde traduz os processos de diluição e concentração da água nas estações chuvosa e seca, respectivamente. Contudo, o monitoramento também ressalta comportamentos sazonais e interanuais que não podem ser explicados por um simples esquema de diluição/concentração.

\subsubsection{Funcionamento interanual}

Considerando-se as variações do nível e da CE da água apresentadas no gráfico (Figura 57), percebe-se que até o final do monitoramento, em outubro de 2011, a Salina Verde ainda não havia recobrado as condições físico-químicas do início do monitoramento, em outubro de 2010. Isto indica existir variações interanuais dessas condições, que dependem da intensidade anual das chuvas.

O modelo conceitual apresentado na Figura 54 permite interpretar, qualitativamente, essa tendência. Tudo indica que o nível das águas não sobe suficientemente a cada ano para ultrapassar a altura da soleira ao redor das salinas. Este é provavelmente, o caso de 2009 e 2010, onde só entrou água na salina diretamente pelas chuvas, provocando sua diluição. Além disto, se as taxas de evaporação anual excederam as de precipitação houve aumento da salinidade de um ano para o outro.

Ao contrário, durante os anos excepcionalmente chuvosos, como foi o caso de 2011, dois mecanismos podem ser responsáveis pela diluição das águas na salina: $1^{\circ}$ ) se as taxas de precipitação anual excederem as de evaporação, observase um efeito de diluição das águas diretamente pelo balanço (P-ETP) positivo; $2^{\circ}$ ) se o nível regional da água no Pantanal se elevar muito, o volume de "Q" que 
ultrapassa a soleira em direção à salina aumenta, e pode gerar um balanço $(Q+P>E T P)$ positivo, provocando, igualmente, uma diluição das águas na salina.

Em resumo, esse modelo (Figura 54) traduz um funcionamento hidrológico a longo prazo, em que o grau de salinidade de uma lagoa se « estabiliza » entorno de um valor médio, em função tanto das taxas anuais de precipitação e evaporação, quanto da altura da soleira ao redor da salina.

\subsubsection{Variabilidade sazonal de salinidade}

O gráfico do monitoramento da água na Salina Verde, Figura 57, também destacou uma variação da salinidade que não pode ser explicada pelo simples esquema de concentração/diluição. Nota-se, no período de 20 de novembro/2010 a 5 de janeiro de 2011, um descompasso entre a curva de resposta da salinidade com a do nível da água na salina. Nesse curto período de tempo a salinidade aumentou abruptamente, passando de 7000 para $2000 \mu$ S.cm ${ }^{-1}$. Em seguida, sem que o nível da água diminuísse, ela voltou rapidamente a subir para $13000 \mu \mathrm{S} . \mathrm{cm}^{-1}$, ou seja, com uma velocidade muito maior do que permite a evaporação. Esse comportamento da curva da salinidade traduz, necessariamente, uma remobilização de um estoque de sal pré-existente, que no início da estação chuvosa é despejado na salina.

Com base nos conhecimentos da morfologia do solo ao redor da salina é possível formular uma hipótese para explicar esse descompasso, e esse aumento brusco da salinidade, logo após sua queda, no inicio da estação chuvosa. Coloca-se em pauta o estoque de água hipersalina, armazenada na base do horizonte (3), também identificado por altos valores de CEa durante o mapeamento por indução eletromagnética (Figura 35). Esse estoque também foi observado nas sondagens 
pontuais, feitas com um trado, onde se mediu a condutividade elétrica (CE) dessa água, cujos valores variam de 15.000 a $80000 \mu S . \mathrm{cm}^{-1}$. Trata-se, efetivamente, de um estoque de água hipersalina, armazenado na goteira formada por duas ondulações pronunciadas dos horizontes (4) e (7) endurecidos (Figura 35).

A Figura 58 apresenta um esquema desse quadro, feito a partir do conhecimento sobre a morfologia da cobertura pedológica ao redor da Salina Verde. Essa morfologia permite propor um modelo teórico de funcionamento da salinidade que pode explicar, de maneira qualitativa, as observações feitas durante o monitoramento da Salina Verde (Figura 59).

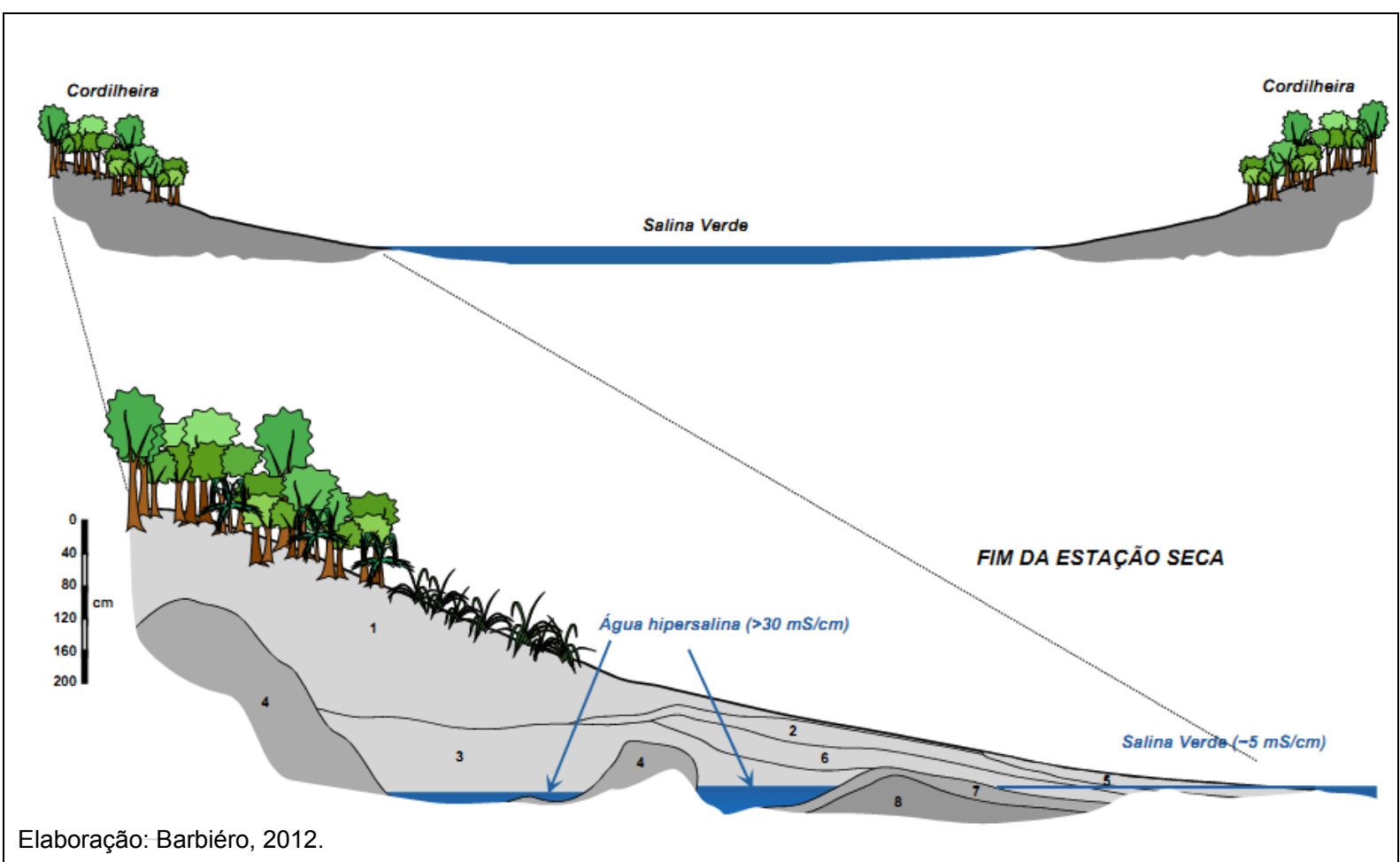

Figura 58. Morfologia da cobertura pedológica ao redor da Salina Verde e funcionamento interanual da salinidade.

A situação inicial (Figura 59-A) corresponde a uma salinidade média da Salina Verde, de $5000 \mu \mathrm{S} . \mathrm{cm}^{-1}$, e presença da água armazenada na base do horizonte (3), com CE da ordem de $30000 \mu \mathrm{S} . \mathrm{cm}^{-1}$. 


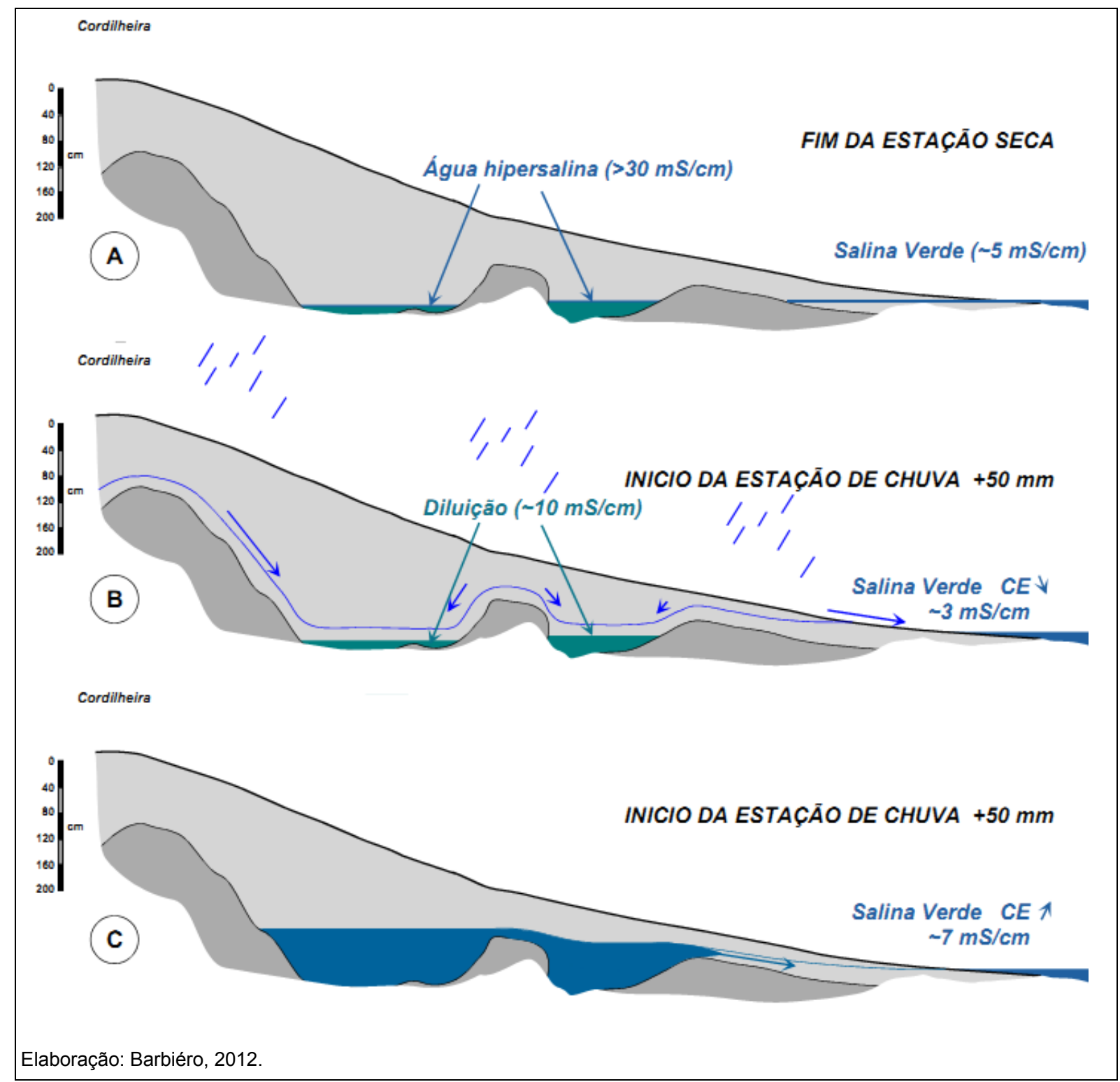

Figura 59. Modelo de Funcionamento Hidroquímico de "Estruturas em Patamares".

Nesta situação inicial, a água da salina não se concentra conectada ao lençol de água hipersalina. Uma precipitação direta, de $50 \mathrm{~mm}$ de chuva, aumenta em $50 \mathrm{~mm}$ o nível da água na salina. Considerando-se que a porosidade nos horizontes arenosos é de aproximadamente $40 \%$, esse volume de chuva provoca no horizonte superficial uma zona de saturação de $125 \mathrm{~mm}$ de espessura (Figura 59-B). A infiltração dessa água é rápida nos horizontes superficiais, arenosos e permeáveis, e ao atingir os horizontes profundos, endurecidos e pouco permeáveis, ela se redistribui nas depressões formadas entre as ondulações destes horizontes 
(Figure 59-C). Ao atingir o estoque de água hipersalina, ela o preenche e promove uma diluição dessa água. O grau de diluição vai depender do volume de água que infiltrou. Se o nível desse lençol hipersalino subir o suficiente para ultrapassar a altura das soleiras, então ele vai se despejar na salina, fazendo aumentar, abruptamente, o grau de salinidade da água, que no início da estação úmida havia começado a diminuir (Figura 59-C).

Esse mecanismo ainda pode ser mais pronunciado após um longo período de seca, em decorrência do qual diminui-se muito o volume de água na salina, e aumenta-se muito o grau concentração da água no reservatório salino, situado ao redor da salina.

Este funcionamento, aqui descrito apenas hipotética e qualitativamente, também pode ser transposto para outras salinas da Nhecolândia, pois essa morfologia da cobertura pedológica, geradora de reservatórios de sal, vem sendo frequentemente, identificada, e descrita, na Nhecolândia, conforme salientou-se no capítulo anterior.

\section{TIPOLOGIA DE SALINAS}

Na definição de critérios para fazer uma tipologia de lagoas é importante considerar o quadro geográfico no qual se inserem, ou tipo de ambiente, se são perenes ou intermitentes, se as fases úmidas e de inundação são regulares ou irregulares, se são profundos ou rasos, dentre outros (Tundisi e Tundisi, 2008). Esse quadro define os fatores ecológicos dos lagos, como morfologia, morfometria, condições edáficas, clima, drenagem, gênese, entre outros. A esses dados ambientais pode-se acrescentar fatores próprios dos lagos, como características 
físico-químicas, biológicas, comportamento limnológico, comunidade fitoplanctônica, entre outras (Kleerekoper, 1944; Izaguirre e Vinocur, 1994; Kolada et al., 2005).

As áreas úmidas naturais apresentam duas grandes categorias, costeiras (marinhas), e interiores (lacustres, fluviais, aluviais, glaciais), cada qual subdividida em diferentes tipos. Dentro dessa tipologia geral, a categoria áreas úmidas interiores do tipo $Q$ e $R$ enquadram lagos salinos, alcalinos, salobros, permanentes ou intermitentes (Barnaud, 1998 e Frazier, 1999 apud Fustec et al., 2000).

Há uma tipologia genética de lagos, cujos principais são: tectônicos, vulcânicos, glaciais, fluviais, eólicos, marinhos, hidroquímicos, desérticos, salinos (Hutchinson, 1957 apud Tundisi e Tundisi 2008; Williams, 1964; Harmmer 1986 apud Lerman et al., 1995; Meybeck, 1995). Nesse quadro, há uma tipologia genérica, em três categorias, para lagos salinos, baseada no total de sólidos dissolvidos (TDS) que apresentam (Meybeck, 1995), isto é, oligo-salinos (TDS < 20g/L), mesosalinos $(20<$ TDS $<40 \mathrm{~g} / \mathrm{L})$ e hipersalinos (TDS $>40 \mathrm{~g} / \mathrm{L}$ ).

No Brasil, destacam-se dois exemplos. O primeiro se refere à tipologia feita para os lagos do sistema lacustre do Médio Rio Doce, baseada em critérios geomorfológicos, como características morfométricas, forma, profundidade máxima e mínima, desenvolvimento de praia; e limnológicos, como processos de misturas, estabilidade de estratificação, circulação efetiva, composição e diversidade biológica, biomassa, produtividade primária, e composição química dos sedimentos (Mousinho Meis e Tundisi, 1986). Esses critérios permitiram aos autores de definir 4 tipos principais de lagos, a saber; Tipo (1) D. Helvécio (dendrítico, profundo, e circulação lenta); Tipo (2) Jacaré e Barra (dendrítico, raso, e circulação rápida), Tipo (3) Lago Carioca (arredondado, raso, maior ciculação efetiva que o tipo D. Helvécio), 
e finalmente, o quarto, que representa os estágios evolutivos finais dos lagos por assoreamento, e Tipo (4) Áreas Alagadas.

O segundo se refere à tipologia feita para o sistema lacustre da várzea do médio e baixo curso do Amazonas, baseado em critérios morfológicos obtidos por imagens radar (Melack, 1984 apud Melack e Fosberg, 2001; Tundisi et al., 1999). Essa tipologia define 6 categorias de lagos em função de suas formas: redondo-oval, dique, dendrítico, crescente, ferradura, composto. Estimou-se também o número de lagos em cada categoria, sendo o tipo predominante o de lago redondo-oval, com 5020 unidades, seguido pelos tipos dique (1520), e dendrítico (830). Recentemente, essa tipologia foi retomada, mostrando-se que essas formas apresentam variações sazonais, resultantes da coalescência e aglutinação dos lagos no período úmido, que fazem com que eles migrem de uma categoria para outra (França, 2007).

\subsection{Critérios para uma tipologia}

Levando-se em conta os critérios acima apresentados, gerais-ambientais e particulares-intrínsecos, selecionou-se um conjunto de dados, obtidos no decorrer deste trabalho, a fim de avaliar se podem ser aplicados numa base, para definir uma tipologia das salinas aqui estudadas.

Elegeu-se dois conjuntos de dados, um morfológico, e outro, das características físico-químicas das águas e sedimentos das salinas.

\subsubsection{Critérios morfológicos regionais}

Para tentar agrupar um conjunto de dados morfológicos sobre as salinas recorreu-se, em primeiro lugar, a um mapeamento fisiográfico de um corte feito na porção sul da Nhecolândia, abrangendo parte do Rio Negro, nas Coordenadas $55^{\circ} 58^{\prime} 20.6$ e $56^{\circ} 10^{\prime} 57.8^{\prime \prime} \mathrm{W}$, e 19²6’08.8' e 19³6'14.7'" S. 
Esse mapeamento foi feito por fotointerpretação de uma imagem de satélite (Google Earth, 2010), de onde foram compiladas informações, para um papel ultrafan e com o apoio de mesa de luz, da rede de drenagem atual, da forma, cor, e tamanho das lagoas, e da vegetação. Este trabalho foi completado por observações de campo, a fim de estabelecer uma legenda apropriada, que viesse a ser representativa da área analisada.

A definição da legenda se apoiou em material cartográfico, principalmente de geomorfologia fluvial (Gregory, 1977; Christofoletti, 1981; Gohain e Parkash, 1990; Ab' Saber, 2006), e do carste (Coutard et. al., 1978; Uagoda, 2006), que contribuíram apenas parcialmente para essa definição.

O mapa está apresentado na Figura 60. Considerando-se que o objetivo aqui não é fazer uma tipologia geral de todas as lagoas mapeadas, o foco será dirigido às lagoas salinas, identificadas no mapa por um "S". Embora a unidade lagoas com praias apresentem as mesmas características das lagoas salinas, elas não foram mapeadas como tal. Como não foi possível verificar cada uma, optou-se por colocá-las dentro de outra unidade, pois todas as lagoas salinas foram confirmadas em campo.

As lagoas Salinas se encontram isoladas da drenagem atual, e apresentam formas arredondadas e alongadas, cercadas de cordilheiras, e praias bem nítidas de areia branca. As praias têm forma bem ajustada à da lâmina da água, apresentam solo arenoso, ausência de vegetação arbustiva, eventualmente com setores restritos de gramíneas.

A distribuição espacial das salinas nessa área mapeada tem, no geral, caráter aleatório, embora integre localmente o alinhamento NE-SW observado no conjunto das lagoas situadas mais nas partes central e extremo SE da Figura. Tudo 
indica que esse alinhamento é concordante com a direção dos paleofluxos identificados no lobo 7, por Zani (2008). Esse lobo abandonado foi caracterizado como o mais antigo do leque aluvial do Taquari por Assine (2003). Percebe-se, à esquerda das Vazantes Castelinho e Castelo, cinco pequenos grupos de salinas, separados por uma grande cordilheira, em branco, que essas salinas se encontram melhor ajustadas a esse alinhamento NE-SW. Embora no lobo 7 tenha sido observada uma tendência dos eixos das lagoas se orientarem no sentido NE-SW (Zani, 2008), nota-se também que essa direção não é a única, nem a predominante, do conjunto de lagoas do sistema lacustre da Nhecolândia, mesmo nesse lobo 7.

Em síntese, os dados morfológicos que podem ser retidos deste mapeamento fisiográfico, e compor critérios para uma tipologia são: forma das salinas, presença de praia branca e cordilheira, isolamento da rede de drenagem atual. 
Figura 60. Mapa de distribuição das principais unidades da paisagem da Nhecolância - Pantanal/MS

$1902608.88^{\prime \prime}$
$56^{\circ} 10^{\circ} 57.8^{\prime \prime}$

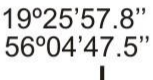

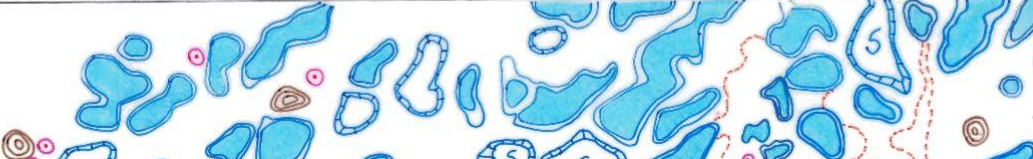

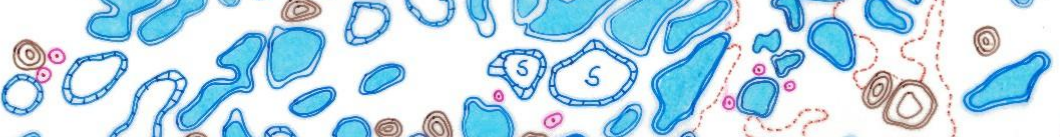

1 5505838.1"

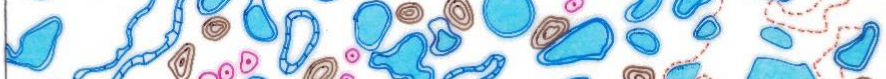

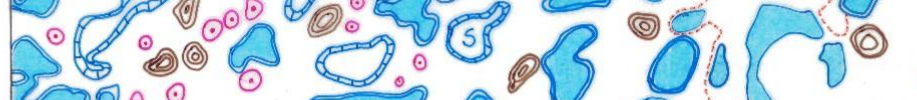

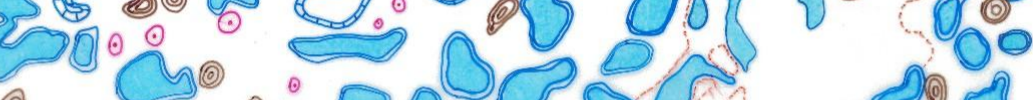

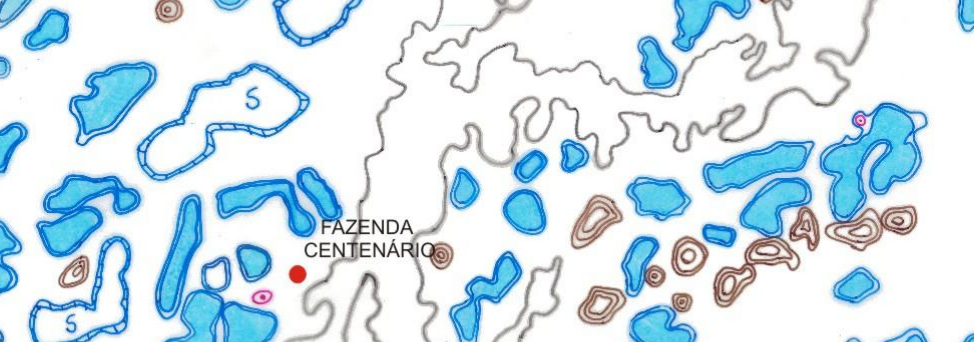
003

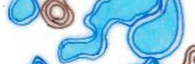

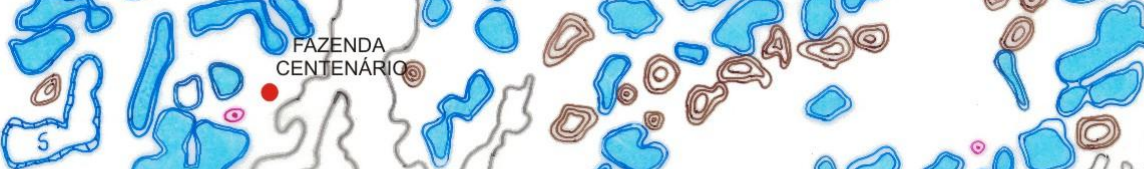

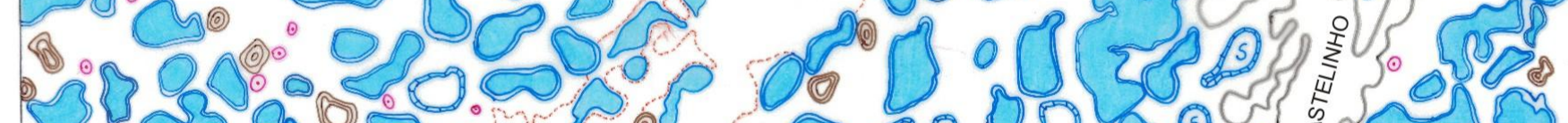

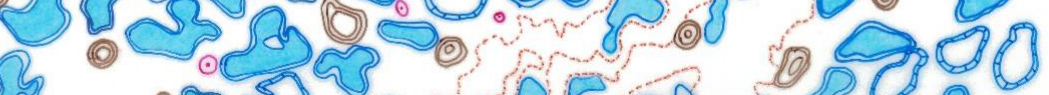

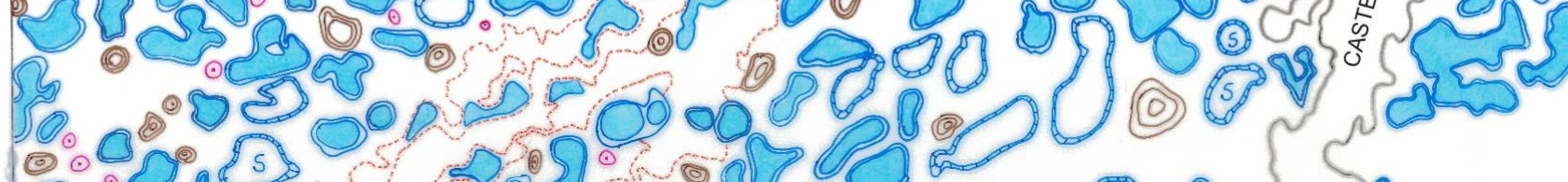

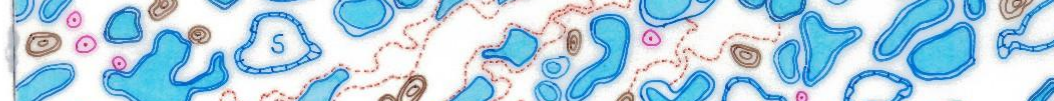

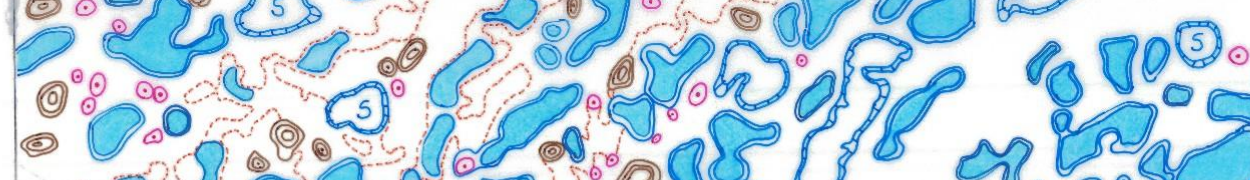
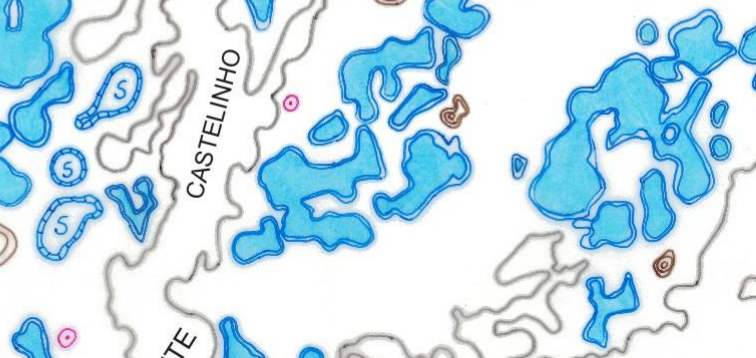
505 1000

.0050002
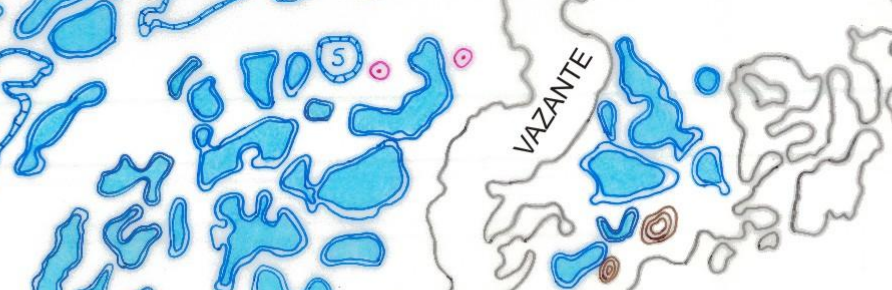
काज?

i. 00003

- D. 200

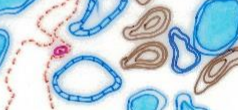

So.

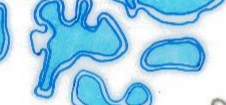

500010

(a) (a)

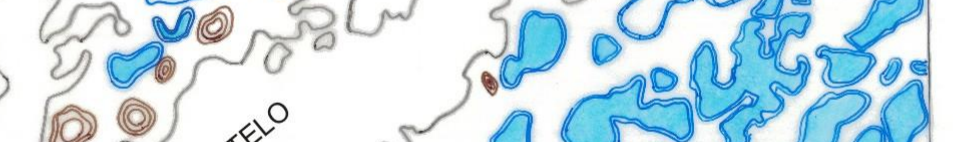

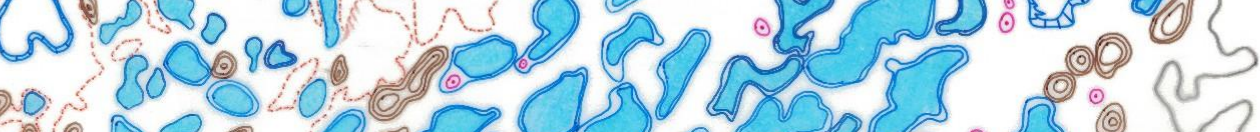

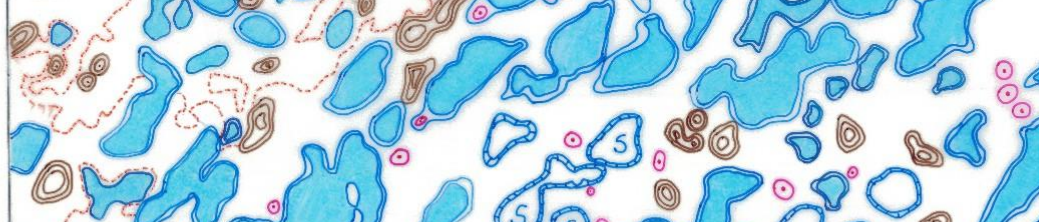

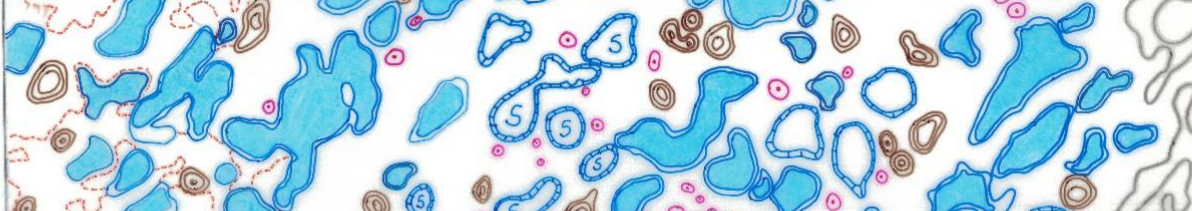

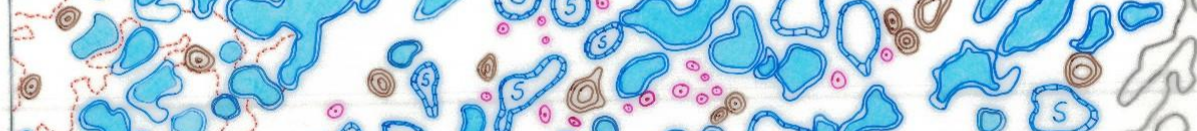

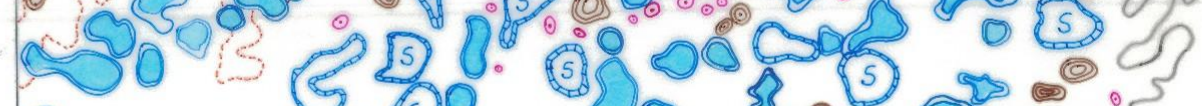

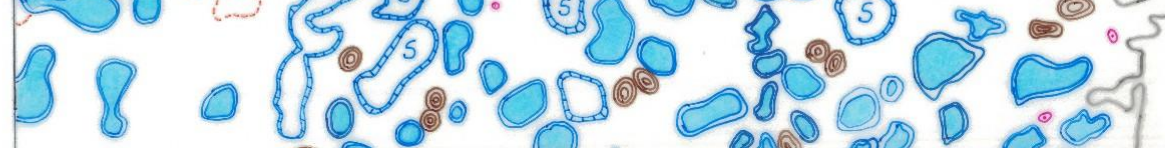
o son.
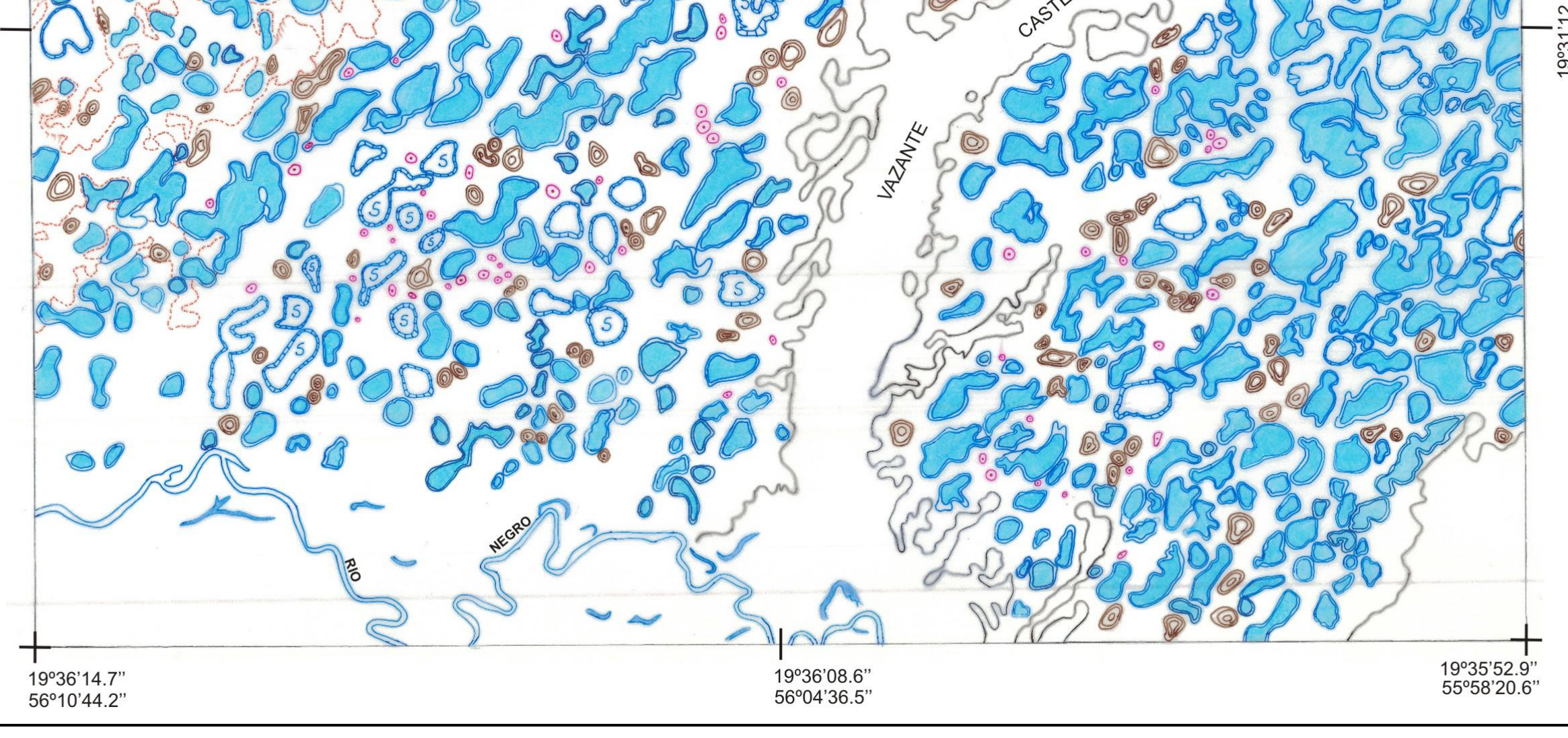

\section{LEGENDA}
Lagoas com praia
(5) Lagoas salinas
Lagoas com diferentes
(C) Lagoas com zoneamento anelar
- Pequenas depressões
高 Vazantes
Vazantes descontinuas e/ou corixos
ـ Meandros abandonados
- Sede da Fazenda

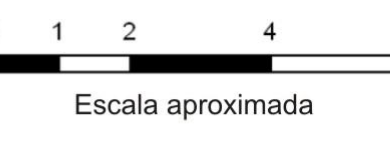 $6 \mathrm{Km}$ 


\subsubsection{Critérios físico-químicos e morfológicos das salinas}

As variáveis selecionadas neste tópico, apresentadas na Tabela 12, envolvem aspectos morfológicos, e características físico-químicas da água e dos sedimentos das salinas, das quais se ressaltam os seguintes aspectos:

(1) CE em $\mu \mathrm{S} . \mathrm{cm}^{-1}$ (Mín-Máx) e pH (Mín-Máx): a maior variabilidade de CE e pH ocorre nas Salinas Grande, Verde e 60 Mil, com maiores amplitudes entre diluição e concentração, que na Salina Preta, onde os valores de CE e pH são menores e relativamente estáveis.

(2) Oxigênio Dissolvido, Algas, Cor e Turbidez: a Salina Preta é a única que não apresenta \% de (OD) acima de 100\%. Isso está em concordância com outra peculiaridade desta salina, a ausência de algas azuis (cianobactérias) em suas águas, cuja cor é preta. Ao contrário, as demais salinas apresentam floração de algas. As algas imprimem cor esverdeada clara na água das (Salinas Grande e 60 Mil), e verde escura (Salina Verde). Cabe ressaltar que nas Salinas Verde e 60 Mil há, temporariamente, uma curta retração da população de algas, quando as águas sofrem significativa diluição pelo aumento do nível da lâmina de água, e principalmente quando ela ultrapassa os limites da própria praia. O índice de turbidez da Salina Preta tende a ser baixo em relação às demais, o que se associa a ausência de algas, e muitos elevados nas Salinas Grande e Verde, geralmente com saturação, e a 60 Mil, passa sazonalmente de < 10 à saturação, com grande variabilidade.

\section{(3) Forma da Salina, Profundidade e Fundo da Salina X Matéria}

Orgânica: as salinas apresentam, basicamente, duas formas: arredondada (Grande e Preta) e alongada com divertículo (Verde e 60 Mil). Todas as salinas são rasas, 
com cerca de $80 \mathrm{~cm}$ as (Salinas Grande e $60 \mathrm{Mil}$ ), com $100 \mathrm{~cm}$ a Verde, e $200 \mathrm{~cm}$ a Salina Preta, a mais profunda de todas. O fundo das salinas difere, principalmente, pela cor, espessura e composição. O fundo das Salinas Grande, Verde e 60 Mil é arenoso, e o da Preta, areno-argiloso. No entanto, entre as salinas com fundo arenoso, a diferença recai na espessura da camada orgânica que o recobre, isto é, nas (Salinas Grande e 60 Mil) essa camada é pouco espessa, aproximadamente 20 $\mathrm{cm}$, cor cinza esverdeada, sendo que na 60 Mil o fundo arenoso é cimentado, em forma de laje, e passagem abrupta entre ele e a camada orgânica. A Salina Preta apresenta uma fina camada orgânica escura, ao contrário da Verde, onde essa camada é muito espessa, superior a $100 \mathrm{~cm}$.

(4) Praia de entorno e resposta aos períodos de estiagens: as praias ao redor das Salinas Grande, Verde e 60 Mil são mais extensas, bem definidas e com eflorescências de sais quando secam no período de estiagem. Na Salina Preta, ao contrário, além da extensão da praia ser menor, ela apresenta arbustos e gramíneas. A Salina Preta é a única a não secar nos períodos de estiagem, mesmo nos mais excepcionais, contrário da Salina Grande, que secou totalmente em setembro/2009, e da Verde e 60 Mil que podem ficar quase totalmente secas no final do período de estiagem. 
Tabela 12. Variáveis selecionadas para o ensaio de tipologia envolvendo as Salinas Grande, Verde, 60 Mil e Preta.

\begin{tabular}{|c|c|c|c|c|}
\hline Água/Salinas & Grande & Verde & $60 \mathrm{Mil}$ & Preta \\
\hline $\begin{array}{c}\text { CE em } \mu \text { S.cm }{ }^{-1} \text { (Mín- } \\
\text { Máx) }\end{array}$ & 2250 a 11470 & 1330 a 19473 & 659 a 60400 & 570 a 4750 \\
\hline $\begin{array}{c}\text { Oxigênio Dissolvido } \\
(\%)\end{array}$ & Alto & Alto & Alto & Baixo \\
\hline $\begin{array}{c}\text { Algas } \\
\text { (cianobactérias) }\end{array}$ & Presente & $\begin{array}{l}\text { Presente com curta } \\
\text { retração. }\end{array}$ & $\begin{array}{l}\text { Presente com curta } \\
\text { retração. }\end{array}$ & Ausente \\
\hline Forma da salina & Arredondada & Alongada com divertículo & Alongada com divertículo & Arredondada \\
\hline $\begin{array}{l}\text { Profundidade } \\
\text { (aproximada) }\end{array}$ & $80 \mathrm{~cm}$ & $1 \mathrm{~m}$ & $80 \mathrm{~cm}$ & $2 \mathrm{~m}$ \\
\hline Praia no entorno & $\begin{array}{l}\text { Bem definida, com areia } \\
\text { branca e eflorescência de } \\
\text { sais no período de seca. }\end{array}$ & $\begin{array}{l}\text { Bem definida, com areia } \\
\text { branca e eflorescência de } \\
\text { sais no período de seca. }\end{array}$ & $\begin{array}{l}\text { Bem definida, com areia } \\
\text { branca e eflorescência de } \\
\text { sais no período de seca. }\end{array}$ & $\begin{array}{l}\text { Com presença de } \\
\text { gramíneas e a forma não } \\
\text { é concordante com os } \\
\text { limites da água. }\end{array}$ \\
\hline $\begin{array}{c}\text { Resposta aos } \\
\text { períodos de estiagem }\end{array}$ & $\begin{array}{l}\text { Pode secar totalmente } \\
\text { (setembro/2009) }\end{array}$ & $\begin{array}{l}\text { Seca quase totalmente } \\
\text { (setembro/2009) }\end{array}$ & $\begin{array}{l}\text { Pode secar totalmente } \\
\text { (setembro/2009) }\end{array}$ & Nunca seca \\
\hline
\end{tabular}




\subsection{Ensaio de tipologia}

Das 11 variáveis apresentadas na Tabela 12, apenas duas, forma e turbidez, não foram selecionadas para o ensaio de tipologia. As outras 11 permitiram identificar 2 grupos de salinas, um formado apenas pela Salina Preta, e o outro, pelas Salinas Verde, Grande e 60 Mil. A variável forma também individualiza 2 grupos, mas com salinas diferentes, um grupo com forma arredondada, Salinas Preta e Grande; e outro, com forma alongada, a Verde e a 60 Mil. A variável turbidez individualizada 3 grupos, com fortes variações, e por isto foi descartada.

Por outro lado, pelo mapeamento fisiográfico identificou-se, na escala da região, diferentes tipos e formas de lagoas. Contudo, essa morfologia regional não pode ser utilizada nessa etapa do ensaio, pois restrito às 4 salinas estudadas em detalhe. Contudo, percebe-se que do ponto de vista da forma, as salinas com alongamento em divertículo (Salina Verde e 60 Mil) são relativamente comuns, com 6 exemplares no mapa, e as de forma arredondada (Salina Grande e Preta), mais frequentes, com 9 exemplares. Para que as salinas identificadas no mapa fisiográfico pudessem integrar o ensaio, seria necessário fazer medidas in situ de suas características físico-químicas, o que não foi possível no decorrer deste trabalho.

As variáveis selecionadas, assim como os dois tipos de salinas que elas permitiram individualizar, estão apresentadas na Tabela 13. 
Tabela 13. Ensaio de Tipologia: Tipo 1 Salina Preta e Tipo 2 Salina Verde, e suas características.

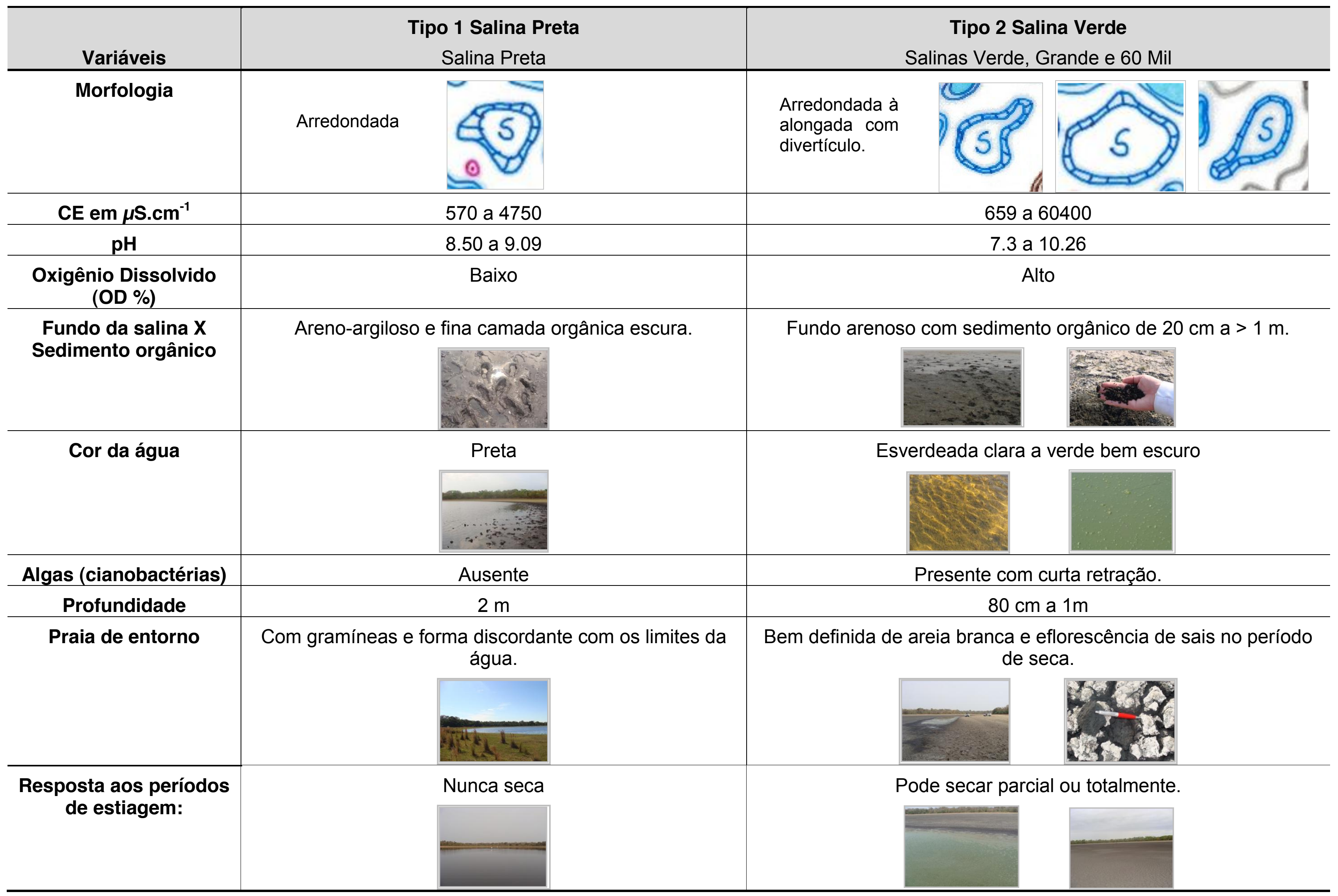




\section{CONSIDERAÇÕES GERAIS}

Neste capítulo foi apresentado, em primeiro lugar, uma síntese sobre a variabilidade química das águas, e da morfologia dos solos ao redor das salinas na Nhecolândia. Para isto, recorreu-se a um modelo teórico de funcionamento hidrológico de salinas, do qual se discutiu a abrangência. Esta síntese salienta, de um lado, a importância da evaporação no processo de concentração das águas; de outro, o fato de que embora as taxas de evaporação excedam as de precipitação no Pantanal, elas são moderadas e insuficientes tanto para acumular quanto para manter sais nessa paisagem. Neste contexto, a salinidade somente pode ser explicada pela morfologia dos solos ao redor das salinas, caracterizada por soleiras formadas por horizontes profundos areno-argilosos endurecidos. Na estaca seca, quando o nível regional da água abaixa, essa soleira fragmenta o lençol freático, que passa a funcionar como segmentos independentes. Um segmento de água doce ligado à cordilheira, e outro de água salgada ligado à salina. Na estação úmida, o aumento regional do nível da água eleva o nível do lençol freático, que por sua vez ultrapassa a soleira, restabelecendo-se a conexão dos dois segmentos.

Esse comportamento tem caráter regional, pois essa morfologia da cobertura pedológica ao redor das salinas tem sido sistematicamente observada e descrita nessa região. Portanto, esse modelo mostra que o grau de salinidade nessa área não depende apenas das condições climáticas, mas, sobretudo, das "estruturas em patamares" formadas pela cobertura pedológica.

Em segundo lugar, o monitoramento da água na Salina Verde mostrou:

$\left(1^{\circ}\right)$ que os dados coletados, seja em escala regional, seja em escala local, convergem para um funcionamento hidroquímico de "estruturas em patamares". 
Esse funcionamento controla, a longo prazo, o grau de concentração das águas nas salinas, quiçá a própria variabilidade regional da condutividade elétrica nas lagoas da Nhecolândia. Neste quadro, as águas mais ou menos concentradas mudam de perfil químico pelos processos de neoformação, envolvendo sínteses de calcita, e de silicatos de magnésio e potássio. A gama de concentração das águas, e as mudanças de perfil químico a ela associadas são igualmente responsáveis pela variabilidade química das águas dessas lagoas;

$2^{\circ}$ ) que esse modelo de funcionamento hidrológico explica, a longo prazo, a presença seja de lagoas salinas, seja de lagoas de água doce. Isto se confirma pela distribuição bimodal da condutividade elétrica das águas em escala regional, e também localmente, pela variabilidade inter-anual da salinidade, que é uma função das taxas anuais de precipitação e evaporação ligadas às características morfológicas da cobertura pedológica ao redor das salinas.

Em terceiro lugar, o ensaio de uma tipologia para as 4 salinas estudadas, feito a partir das principais similaridades físico-químicas entre elas, permitiu definir 2 tipos de salinas. O Tipo 1 Salina Preta difere do Tipo 2 Salina Verde em praticamente todas as variáveis selecionadas. Isto parece evidenciar um funcionamento hidro-biogeoquímico muito diferente entre o Tipo 1 Salina Preta, e o Tipo 2 Salina Verde, onde se incluem as Salinas Grande e 60 Mil, comprovam que o universo "Salinas" no sistema lacustre da Nhecolândia não é homogêneo. 
CONCLUSÃO GERAL 
Os objetivos que nortearam esta pesquisa foram identificar, e compreender, os eixos da variabilidade química das águas da Nhecolândia e suas distribuições espaciais, bem como os processos responsáveis pela variabilidade e suas influências no funcionamento hidrobiogeoquímico das salinas. Com base neste conjunto de informações, principalmente das características físico-químicas e morfológicas das salinas e seu entorno imediato, buscou-se definir critérios para propor uma tipologia de salinas. As principais conclusões deste trabalho serão apresentadas por tópicos, dos quais um será dedicado às perspectivas futuras de trabalhos.

\section{1 - Variabilidade química das águas regionais da Nhecolândia}

O estudo regional da variabilidade química das águas superficiais mostrou, por meio da Análise em Componentes Principais, que o processo de concentração e diluição das águas explica até $86 \%$ da variabilidade total, que demonstra a importância desse processo na Nhecolândia. Embora as gamas de condutividade elétrica das águas serem amplas, as condições climáticas atuais (ETP/P cerca de 1.3) não são favoráveis nem a uma salinização por evaporação, nem a uma manutenção da salinidade na paisagem.

Estes resultados levaram a duas hipóteses, não excludentes, sobre a origem da salinidade das lagoas da Nhecolândia: $1^{a}$ ) uma ligada à presença de um estoque de sal, provavelmente acumulado em fases secas pretéritas, mas que ainda pode marcar a química da água localmente; $2^{\mathrm{a}}$ ) outra ligada a um processo com efeito acumulativo no tempo, de ano para ano, e a distribuição atual da salinidade na paisagem seria decorrente de anos de funcionamento desse sistema de lagoas. Neste caso, contudo, a condição de manutenção da salinidade é o isolamento das 
águas salinas dos fluxos atuais, e anuais, das águas superficiais pouco mineralizadas das cheias do Pantanal.

\section{2 - Distribuição estatística da CE das águas de superfície}

A condutividade elétrica se revelou um parâmetro pertinente para estudo da distribuição espacial da variabilidade química das águas na Nhecolândia, e sua transformação logarítmica, em $\log _{10}(C E)$, relevante para análises espaciais.

A distribuição estatística da CE das águas é bimodal, e traduz pela moda principal a presença de lagoas com água diluída, e pela moda secundária, a de lagoas com água concentrada, e uma quase ausência de lagoas com água de concentrações intermediárias. Isto indica que o processo que controla a salinidade age de modo dicotômico, favorecendo ou águas doces ou águas salinas.

O variograma experimental da variável $\log _{10}(C E)$ indica uma ausência de padrão espacial na distribuição da condutividade elétrica das águas em escala regional. Ele ressalta um alcance pequeno da variável, e mostra, efetivamente, que acima de 200 m não há mais correlação espacial entre os valores. Considerando-se que esta distância corresponde, aproximadamente, a mais curta distância que separa duas lagoas, conclui-se que a CE das águas das lagoas são independentes entre si.

Isto reforça a hipótese de que o processo que controla a salinidade das águas superficiais age localmente, entre lagoas, mais precisamente, na cobertura pedológica ao redor das lagoas.

\section{3 - Morfologia das salinas e o comportamento do lençol freático.}

O estudo em escala local, por meio de observações diretas e indiretas, ressalta a similaridade morfológica da cobertura pedológica ao redor das salinas, 
mas também com a de outras áreas da Nhecolândia, revelando tratar-se de um “padrão" morfológico regional.

Uma das características morfológicas da cobertura pedológica a ser destacada é a forma ondulada do contato, abrupto, entre o conjunto de horizontes superficiais arenosos, e os horizontes profundos endurecidos, franco-arenosos a areno-argilosos, que apresentam forma ondulada, cujas ondulações são mais ou menos abertas. O contraste de permeabilidade entre esses horizontes produz uma diminuição na permeabilidade, da ordem de 1000, exatamente nesse contato. Consequentemente, esse contato passa a controlar os fluxos da água subsuperficial, e funciona como uma soleira que se manifesta com uma fragmentação do lençol freático. Constatou-se que essas elevações se situam na cordilheira, a uma distância aproximada de $200 \mathrm{~m}$ da borda das salinas. Outro fator importante a ressaltar é a existência de um estoque de água hipersalina sujeita à remobilização, armazenada na base do horizonte (3). Essas observações levaram ao monitoramento da água na Salina Verde.

\section{3 - Variabilidade sazonal da salinidade}

Os dados do monitoramento da salinidade na Salina Verde, assim como os resultados dos estudos, regional e local, da variabilidade química convergem para um funcionamento hidroquímico de estruturas em patamares. Esse funcionamento controla, a longo prazo, o grau de concentração das águas nas salinas, mas também a variabilidade regional da salinidade nas águas das lagoas da Nhecolândia.

O modelo de funcionamento hidrológico apresentado explica não apenas a presença de salinas, mas igualmente a de lagoas de água doce. A abrangência desse modelo foi confirmada pelos resultados do presente trabalho, sobretudo pela distribuição bimodal da condutividade elétrica das águas, e variabilidade interanual 
da salinidade. Esta variabilidade interanual é função do jogo entre condições climáticas, taxas anuais de precipitação e evaporação, e características morfológicas da cobertura pedológica, principalmente, da altura das soleiras ao redor das salinas. Embora esse modelo hidrológico tenha abrangência regional, ele não explica as diferenças de salinidade entre salinas, nem as diferenças de salinidade de uma salina ao longo do tempo.

A hipótese para explicar as mudanças abruptas da salinidade nas salinas, em intervalos de tempo muito curtos, está associada ao nível do lençol hipersalino subsuperficial. No início da estação úmida, o nível da água do lençol pode subir o suficiente para ultrapassar a altura das soleiras, e então o reservatório de águas hipersalinas é despejado na salina, fazendo aumentar, abruptamente, sua salinidade.

Levando-se em conta as observações realizadas, a hipótese é que este modelo de funcionamento pode ser ampliado a outras salinas, pois essa morfologia, com reservatório salino dentro da cobertura pedológica, tem sido também identificada em outras porções da Nhecolândia.

Outro fator importante a ressaltar, ligado a essa variabilidade inter-anual da salinidade, é o comportamento das algas azuis (cianobactérias) nas Salinas Verde e 60 Mil. Observou-se que por um curto espaço de tempo houve uma significativa redução de algas. Isto ocorreu quando as salinas se diluíram pelo aumento do nível da água na estação úmida. Depois, à medida que as águas voltaram a concentrarse, iniciou-se uma produção primária que aumentou em direção ao período seco, com ocorrência até de florações de algas. Isto vem confirmar que as cianobactérias se desenvolvem melhor nesses ambientes alcalinos das salinas, com valores elevados de condutividade elétrica e de $\mathrm{pH}$, como mostrado por Santos et al., 2011. 


\section{4 - Ensaio de tipologia}

Em função do número de salinas estudadas em escala local ser relativamente pequeno, para transformar o "ensaio de tipologia" numa "tipologia de salinas" efetiva, é necessário recorrer-se a observações e medições físico-químicas das demais salinas identificadas no mapeamento fisiográfico.

Algumas observações e medições de campo efetuadas em mais 2 salinas (Salina Almir Sater e 37000 Mil) possibilitam enquadrá-las no Tipo 2 Salina Verde. Destas 2 salinas, a primeira apresenta características similares à Salina Verde, e a segunda, à 60 Mil. Esses dados não foram utilizados para o ensaio de tipologia aqui realizado, pelo fato do número de medições ser relativamente menor, dadas as condições de campo nos períodos úmidos não permitirem acesso às salinas.

Enfim, esse ensaio deixa entrever funcionamentos hidro-biogeoquímicos diferenciados entre as salinas de Tipo 1 Salina Preta, e as de Tipo 2 Salina Verde, e comprovam que as salinas não constituem um universo homogêneo no sistema lacustre da Nhecolândia.

\section{5 - Perspectivas para trabalhos futuros}

No futuro, o mapeamento fisiográfico aqui realizado em um pequeno recorte espacial, deve ser ampliado a toda Nhecolândia, de maneira que possibilite compreender melhor identificadas, as relações entre as unidades morfológicas identificadas, principalmente com a drenagem. A importância desse mapeamento é reforçada na medida em que se observa uma forte associação entre variabilidade morfológica das lagoas e variabilidade química das águas.

Para a continuidade do monitoramento anual e sazonal da salinidade nas salinas da Nhecolândia, sugere-se seguir com o método de aquisição de dados pela instalação de sondas, modelo "CTD Diver", em outras salinas, que se mostrou muito 
eficiente na Salina Verde. Em complementaridade a essas informações, pesquisas futuras não podem se prescindir da instalação de uma Mini Estação Meteorológica automática, para aquisição de séries longas de dados locais de precipitações, e evaporação, visto que as taxas de precipitação mensal obtidas localmente diferem muito dos registros da estação meteorológica de Aquidauana, a mais próxima da área de estudo.

Do mesmo modo, para passar de um ensaio para uma tipologia efetiva das salinas é necessário obter séries de medições mais longas e sistemáticas, das variáveis utilizadas neste trabalho. Um conjunto maior de informações podem definir melhor o perfil físico-químico das salinas, e servir de base para uma tipologia mais ampla que venha abarcar um maior número de Salinas.

O estudo detalhado das 4 salinas mostrou que a Salina Preta é muito diferente das demais, o que é demonstrado claramente no ensaio de tipologia. Em campo, por meio de observações pontuais do solo e da água, se constatou em algumas porções do entorno desta salina, a presença de um horizonte orgânico preto, que é provavelmente transferido em solução para a água da Salina, que é preta. Durante este trabalho, não foi possível estudar melhor esse horizonte. A partir disto, colocam-se algumas questões: $1^{\circ}$ ) Estaria a Salina Preta se dessalinizando, e por isso, apresenta um funcionamento hidroquímico muito diferente das demais (?) e, $2^{\circ}$ ) Qual é a relação entre suas características fisico-químicas e a morfologia da salina, cuja praia não é concordante com os limites da água, diferentemente das demais salinas. Além disto, constatou-se que a condutividade elétrica aparente do solo (CEa) dessa porção oeste "discordante" é extremamente baixa. $3^{\circ}$ ) Existiria alguma associação dessa morfologia com a drenagem de entorno, e por isso, esta salina nunca vem a secar nos períodos de estiagem (?). Neste sentido, sugere-se 
investigações mais detalhadas envolvendo a organização pedológica do seu entorno, bem como análises mais detalhadas dos sedimentos orgânicos e da água.

A morfologia alongada, com divertículo, das Salinas Verde e 60 mil, é frequente na Nhecolândia. No estudo realizado neste trabalho são exatamente essas salinas que apresentam a maior variabilidade de CE, ou de salinidade, sobretudo a 60 Mil que passou, de uma estação para outra, de 659 a $60.400 \mu \mathrm{S} \mathrm{cm}^{-}$ ${ }^{1}$. Estas informações sugerem maiores estudos da laje, sobretudo de sua relação com a pouca profundidade dessa salina.

Pesquisas futuras, baseadas em monitoramentos sequências de dados ao longo do tempo, com medições abrangendo sucessões de estações seca e úmida, poderiam também viabilizar uma modelização, com simulação da evolução dessas salinas. 
REFERÊNCIAS BIBLIOGRÁFICAS 


\section{REFERÊNCIAS BIBLIOGRÁFICAS}

Ab'Saber, A. N. 1954b. O Pantanal dos Parecis na região de Diamantino (Mato Grosso). In: Boletim Paulista de Geografia, São Paulo, n.17, 63-69p.

Ab'Saber, A. N. 1957. Contribuição à geomorfologia do Litoral Paulista. Revista Brasileira de Geografia, ano XVII, n. 1, 3-48p. Rio de Janeiro.

Ab'Saber, A. N. 1966. O domínio dos mares de morros no Brasil. Geomorfologia, São Paulo, n. 2. p.1-9.

Ab'Sáber, A. N. 1988. O Pantanal Mato-Grossense e a teoria dos refúgios. Revista Brasileira de Geografia, 50 (número especial 1-2): 9-57p.

Ab'Saber, A. N. 2006. Brasil: Paisagens de Exceção: o litoral e o Pantanal MatoGrossense patrimônios básicos. Cotia, SP: Ateliê Editorial, 182p.

Adámoli, J. 1986. A dinâmica das inundações no Pantanal. In: Anais do $1^{\circ}$ Simpósio sobre recursos naturais e sócio-econômicos do Pantanal. Brasília - DF. DDT Embrapa/CPAP - UFMS. Documentos 5:51-61p.

Adámoli, J. 1982. O Pantanal e suas relações fitogeográficas com os cerrados: discussão com o conceito "complexo do Pantanal". In: Congresso Nacional de Botânica 32, Teresina - Anais...Teresina: Sociedade Botânica do Brasil. 109-119p.

Alfonsi, R. R., Camargo, M. B. P. 1986. Condições climáticas para a Região do Pantanal Matogrossense. In: $1^{\circ}$ Simpósio sobre recursos naturais e sócio-econômico do Pantanal, 1., 1984. Corumbá/MS. Anais... Brasília: EMBRAPA-DDT, p. 29 a 42, (EMBRAPA, CPAP. Documentos, 5).

Almeida, F. F. M. 1945. Geologia do Sudoeste Matogrossense. Boletim do DNPM/DGM, 116: 1-118p.

Almeida F. F. M., Lima, M. A. 1956. Excursion guidebook 1.18th International Congress of Geography. Rio de Janeiro, Brazil.

Almeida, T. I. R. de, Sígolo, J. B., Fernandes, E., Queiroz Neto, J. P. de; Barbiero, L.; Sakamoto, A. Y. 2003. Proposta de classificação e gênese das lagoas da Baixa Nhecolândia - MS com base em sensoriamento remoto e dados de campo. Revista Brasileira de Geociências, 83-90p.

Almeida, T. I. R. de., Fernandes, E., Mendes, D., Sígolo, J. B. 2006. Distribuição espacial de diferentes classes de lagoas do Pantanal da Nhecolândia, MS: uma contribuição ao estudo de sua compartimentação e gênese. Anais: I Simpósio de Geotecnologias no Pantanal, Campo Grande, Brasil: Embrapa Informática Agropecuária/INPE, 155-164p.

Alvarenga, S. M.; Brasil, A. E.; Pinheiro, R.; Kux, H. J. H. 1984. Estudo geomorfológico à Bacia do Alto Rio Paraguai e Pantanais Mato-Grossenses. In: Brasil. Ministério das Minas e Energia. Secretaria Geral. Projeto RadamBrasil. Boletim Técnico.

Alvarenga, S. M., Brasil, A. E., Del'Arco, D. M. 1982. Geomorfologia. In: Brasil. Ministério das Minas e Energia. Projeto RadamBrasil. Folha SF.21 Campo Grande, 1982. (Levantamento de Recursos Naturais, 28). 125-184p. 
Anderson, R. E.; Black, W. C.; Hair Jr., J. F.; Tatham, R. L. 2005. Análise Multivariada de Dados. Editora: Bookman Companhia ED, edição 1, 600p.

Arruda Justiniano, L. A. de. 2010. Dinâmica Fluvial do Rio Paraguai entre a foz do Sepotuba e a foz do Cabaçal. Dissertação (Universidade do Estado do Mato Grosso), Cáceres. 71p.

Assine, M. L. 2003. Sedimentação na Bacia do Pantanal Mato-grossense, CentroOeste do Brasil. Rio Claro, SP: 106p. Tese (Livre-Docência) - UNESP - Instituto de Geociências e Ciências Exatas, Departamento de Geologia Sedimentar, Campus de Rio Claro.

Assine, M. L., Soares, P. C. 2004. Quaternary of the Pantanal, west-central Brazil. Quaternary International 114 (1): 23-34p.

Assine, M. L. 2005. River avulsions on the Taquari megafan, Pantanal Wetland, Brazil. Geomorphology v. 70, 357-371p.

Assine, M. I., Silva, A. 2009. Contrasting fluvial styles of the Paraguay river in the northwestern border of the Pantanal wetland, Brazil. Geomorphology, v. 113, n. 3-4, 189-199p.

Assine, M. L. 2010. Pantanal Mato Grossense: uma paisagem de exceção. In: $A$ obra d Aziz Nacib Ab'Saber. Orgs: Modenesi-Gauttiere, M. C.; Bartorelli, A.; Mantesso-Neto, v.; Carneiro, C. D. R.; Lisboa, M. B. de A. L. São Paulo: editora Beca-BALL.

Azevedo, A. de. 1964. Brasil: a Terra e o Homem. Companhia Editora Nacional, São Paulo.

Barbiero, L, Cunnac, S., Mané, L., Laperrousaz, C., Hammecker, C., Maeght, J. L. 2001. Salt distribution in the Senegal middle valley analysis of a saline structure on planned irrigation schemes from N'Galenka creek. Elsevier, Agricultural Water Management, 46, 201-213p.

Barbiero, L., Queiroz Neto, J. P., Ciornei, G., Sakamoto, A., Capellari, B., Fernandes, E., Valles, V. 2002. Geochemistry of water and groundwater in the Nhecolândia, Pantanal of Mato Grosso, Brazil: variability and associated processes. Wetlands, v.22, n.3, 528-540p.

Barbiero L., Valles V., Cheverry C., 2004. Reply to the comment - Some observations with respect to sodicity hazard of irrigation waters, by Van Hoorn, J.W. Agricultural water Management 68, 177-184p.

Barbiero, L., Mohamedou, A., Roger, L., Furian, S., Aventurier, A., Rémy, J. C., Marlet, S. 2005. The origin of Vertisols and their relationships to Acid Sulface Soils in the Senegal valley. Revista Catena, Elsevier, 93-116p.

Barbiéro, L., Furquim, S. C., Valles, V., Furian, S., Sakamoto, A., Rezende Filho, A. T., Graham, R. C., Fort, M. 2007. Natural arsenic in Groundwater and alkaline lakes at the upper Paraguay basin, Pantanal, Brazil. In Battacharya P., Mukherjee A.B., Bundschuh J., Zevenhoven R., Loeppert R.H. (Ed.) Arsenic in Soil and Groundwater Environment: Biogeochemical interactions. Elsevier Book Series "Trace metals and other contaminants in the environment" (J.O. Nriagu, Serie Ed.), v 9, Chapter 4, 101$126 p$. 
Barbiero, L., Rezende Filho, A. T., Furquim, S. A. C., Furian, S.; Sakamoto, A. Y.; Valles, V.; Graham, R. C.; Fort, M.; Fereira, R. P. D.; Queiroz Neto, J.P. 2008. Soil morphological control on saline and freshwater lake hydrogeochemistry in the Pantanal of Nhecolândia, Brazil. Geoderma, 148: 91-106p.

Barros, A. M., Silva, R. H. da., Cardoso, O. R. F. A., Freire, F. A., Junior, J. J. S., Rivetti, M., Luz, D. S. da, Palmeira, R. C. B, Tassinari, C. C. G. 1982. Geologia. In: Brasil. Ministério das Minas e Energia. Projeto Radam Brasil. Folha SD.21. Cuiabá. (Levantamento de Recursos Naturais, 26) 25-192p.

Barroux, G, Sonke, J. E., Boaventura, G., Viers, J., Godderis, Y., Bonnet, M. P., Sondag, F., Gardoll, S., Lagane, C., Seyler, P. 2006. Seasonal dissolved rare earth element dynamics of the Amazon River main stem, its tributaries, and the Curuaí floodplain. Geochemistry, Geophysics, Geosystems, 7, 1-18p.

Bauer-Gottwein, P., Langer, T., Prommer, H., Wolski, P., Kinzelbach, W. 2007. Okavango Delta Islands: interaction between density-driven flow and geochemical reactions under evapo-concentration. Elsevier, Journal of Hydrology, 335: 389-405p.

Bauer, P., Supper, R., Zimmermann, S., Kinzelbach, W. 2006. Geoelectical imaging of groundwater salinization in the Okavango Delta, Botswana. Elsevier, Journal of Applied Geophysics 60, 126-141p.

Bennett, D. L., George, R. L. 1995. Using the EM38 to measure the effect of soil salinity on eucalyptus geobulus in south-western Australia. Elsevier, Agricultural Water Mangement (27): 69-86p.

Bezerra-Neto, J. F., Pinto-Coelho, R. M. 2008. Morphometric study of Lake Dom Helvécio, Parque Estadual do rio Doce (PERD) Minas Gerais, Brazil: a re-avaluation. Acta Limnologica Brasiliensia, V. 20, n 2, 161-167 p.

Boulet, R., Chauvel, A., Humbel, F.X., Lucas, Y. 1982. Analyse structurale et cartographie en pédologie. I - Les études de toposéquences et principaux apports à la connaissance des sols. II - Une méthode d'analyse prenant en compte l'analyse tridimensionnelle des couvertures pédologiques. III - Passage de la phase analytique à une cartographie générale synthétique. Cahier ORSTOM Séries Pédologie 19, 309-351p.

Braun, E. H. G. 1977. Cone Aluvial do Taquari - Unidade Geomorfológica marcante na Planície Quaternária do Pantanal. Revista Brasileira de Geografia, 39, n 4, 164180p.

Brighenti, L. S. 2009. Avaliação limnológica da Lagoa Central (Município de Lagoa Santa-MG) Uma abordagem espacial. Dissertação (Mestrado em Ecologia, Conservação e Manejo da Vida Silvestre) Universidade Federal de Minas gerais. Belo horizonte. 91p.

Brum, P. A. R.; Sousa, J. C. 1985. Níveis de nutrientes minerais para gado, em lagoas ("baías" e "salinas") no Pantanal Sul-Matogrossense. Pesquisa Agropecuária Brasileira. Brasília, v 20 (12), 1451-1454p.

Camargo, E. C. G. 1997. Desenvolvimento, implementação e teste de procedimentos geoestatísticos (Krigagem) no sistema de processamento de informações georreferenciadas (Spring). Dissertação de Mestrado (Instituto Nacional de Pesquisas Espaciais), São José dos Campos, 123p. 
Carvalho, N. O. 1986. Hidrologia da Bacia do Alto Paraguai. In: Anais do $1^{\circ}$ Simpósio sobre recursos naturais e sócio-econômicos do Pantanal, 27 de novembro a 4 de dezembro de 1984, Corumbá (MS), 43-49p.

Chakraborty T, Kar R; Ghosh P. et al., 2010. Kosi megafan Historical records, geomorphology and the recent avulsion of the Kosi River. Quaternary International, v. 227, issue 2, 143-160p.

Christofoletti, A. 1974. Geomorfologia. São Paulo: Edgard Blücher, UNESP, $2^{\circ}$ ed., $150 p$.

Christofoletti, A. 1981. Geomorfologia fluvial. V. 1, São Paulo: Edgard Blücher. 313p.

Colinvaux, P. A., Oliveira, P. E., Bush, M. B. 2000. Amazonian and neotropical plant communities on glacial time-scales. The failure of the aridity and refuge hypotheses. Quaternary Science Reviews v. 19 (1), 141-169p.

Corradini, F. A., Zani, H., Assine, M. L., Kuerten, S., Silva, A., Gradella, F. S. 2009. Paleocanais distributários, incisão fluvial, construção e abandono de lobos deposicionais na evolução geomorfológica do megaleque do São Lourenço, Pantanal Mato-Grossense. In: Simpósio de Geotecnologias no Pantanal, 2, Corumbá. Anais... Embrapa Informática Agropecuária, 115-123 p.

Costa, J. B. S. Hasui, Y., 1997. Evolução geológica da Amazônia. In: Costa, M. L, Angélica, S. (Eds.), Contribuições à Geologia da Amazônia. Sociedade Brasileira de Geologia, Belém, 15-19p.

Coutard, J. P., Journaux, A., Marotta Melfi, C., Ozouf, J. C., Queiroz Neto,, J. P e Scatolini Watanabe, A. 1978. Carta Geomorfológica do Vale do Rio do Peixe em Marília, SP. Esc. 1.100.000. São Paulo, USP, Instituto de Geografia, Sedimentologia e Pedologia 10, 22p.

Coutinho, A. C. 1990. Segmentação e classificação de imagens Landsat-TM para mapeamento dos usos da terra na região de campinas. Dissertação de mestrado, Departamento de Ecologia, Instituto de Biociências, USP.

Cowardin, L. M., Carter, V.; Golet, F. C.; LaRoe, E. T. 1979. Classification of Wetlands and Deepwater Habitats of the United States. (U. S. Wildlife Service), Washington, 131p.

Cunha, J. da. 1943. Cobre do Jauru e lagoas alcalinas do Pantanal (Mato Grosso). Boletim do Laboratório da Produção Mineral, Rio de janeiro, 6:1-43p.

Cunha, N. G. 1981. Classificação e fertilidade de solos da Planície Sedimentar do Rio Taquari, Pantanal Matogrossense. Circular Técnica Embrapa, vol. 4, 1-55p.

Del'Arco, J. O., Silva, R. H., Tarapanoff, I., Freire, F. A., Pereira, L. G. M., Souza, S. L., Luz, D. S., Palmeira, R. C. B., Tassinari, C. C. G. 1982. Geologia da Folha SE. 21, Corumbá e parte da Folha SE. 20. In: RadamBrasil - Levantamento dos recursos naturais. Rio de Janeiro. 25-160p.

Dessert, C., Dupré, B., Gaillardet, J., François, L. M., Allègre, C. J. 2003. Basalt weathering laws and the impact of basalt weathering on the global carbon cycle. Chemical Geology, V. 202, Issues 3-4, 257-273p.

Diaz, L., Herrero, J. 1992. Salinity estimates in irrigated soils using electromagnetic induction. Soil Science 154 (2): 151-157p. 
Dupré, B., Dessert, C., Oliva, P., Goddéris, Y., Viers, J., François, L. 2003. Rivers, chemical weathering and Earth's climate. Comptes Rendus Geoscience, Volume 335, Issue 16, 1141-1160p.

Eiten, G. 1983. Classificação da vegetação do Brasil. CNPq/Coordenação editorial, Brasília, Brasil. 305p.

EMBRAPA. 2006. Sistema Brasileiro de Classificação de Solos. Centro Nacional de Pesquisa de Solos. $2^{\circ}$ Ed. Rio de Janeiro. 306p.

Esteves, F. de A. 1988. Fundamentos de Limnologia. Rio de Janeiro: Interciência: FINEP. 61-89p.

Facincani, E. M., Assine, M. L., Silva, A., Zani, H., Araújo, B. C. Miranda, G. M. 2006. Geomorfologia fluvial do leque do rio Aquidauana, borda sudeste do Pantanal, MS. In: Anais $1^{\circ}$ Simpósio de Geotecnologias no Pantanal, Campo Grande, Brasil, p. 175-181.

Fernandes, E. 2007. Organização espacial dos componentes da paisagem da Baixa Nhecolândia - Pantanal de Mato Grosso do Sul. Tese de Doutorado (Universidade de São Paulo), São Paulo, SP, 176p.

Ferraz-Vicentini, K. R., Salgado-Labouriau, M. L. 1996. Palynological analysis of a pal swamp in central Brazil. Journal of South American Earth Sciences 9, 207-219p.

França, A. M. S de. 2007. Aplicação do sensoriamento remoto no estudo da influência da dinâmica sazonal do Rio Amazonas sobre a morfologia dos sistemas lacustres. Dissertação de Mestrado (Instituto Nacional de Pesquisas Espaciais INPE), São José dos Campos. 134p.

França, A. M. da S., Patrícia, G., Sano, E. E. 2008. Gênese e morfologia dos sistemas lacustres da planície aluvial do Rio Araguaia. Anais. In: IX Simpósio Nacional Cerrado e II Simpósio Internacional Savanas Tropicais. Brasília, 1-7p.

Franco, M. S. M., Pinheiro, R. 1982. Geomorfologia da Folha SE.21. Corumbá e parte da Folha SE.20. In: RadamBrasil - Levantamento dos recursos naturais. Rio de Janeiro, p. 161-224.

Furch, K. e Junk, W. J. 1997. Physicochemical conditions in the floodplains. In: Junk, W. J. (Ed) The Central Amazon Floodplain: ecology of a pulsing system. Ecological Studies, v. 126, Springer, 69-117 p.

Furian, S. Mohamedou, A. O., Hammecker, C., Maeght, J. L., Barbiero, L. 2011. Soil cover and landscape evolution in the Senegal floodplain: a review and synthesis of processes and interactions during the late Holoceno. European Journal of soil Science. 1-11p.

Furquim, S. A. C. 2007. Formação de carbonatos e argilo-minerais em solos sódicos do Pantanal Sul-Mato-Grossense. São Paulo, Tese (Doutorado em Geografia), Faculdade de Filosofia, Letras e Ciências Humanas, Universidade de São Paulo, $171 \mathrm{p}$.

Furquim, S. A. C., Graham, R., Barbiero, L., Queiroz Neto, J. P. de, Valles, V. 2008. Mineralogy and genesis of smectites in an alkaline-saline environment of Pantanal wetland, Brazil. Clays and Clay Minerals, v. 56, 580-596p. 
Furquim, S. A. C., Graham, R. C., Barbiero, L., Queiroz Neto, J. P., Vidal-Torrado, P. 2010. Soil mineral Genesis and distribution in a saline lake landscape of the Pantanal Wetland, Brazil. Elsevier, Geoderma 154, 518-528p.

Furquim, S. A. C., Barbiero, L., Graham, R. C., Queiroz Neto, J. P., Ferreira, R. P. D., Furian, S. 2010. Neoformation of micas in soils surrounding and alkaline-saline lake of Pantanal Wetland, Brazil. Elsevier, Geoderma 158, 331-342p.

Gates, J. B; Edmunds, W. M.; Darling, W. G., Ma, J., Pang, Z., Young, A. A. 2008. Conceptual model of recharge to southeastern Badain Jaran Desert groundwater and lakes from environmental tracers. Elsevier, Applied Geochemistry, v. 23, Issue 12, 3519-3534p.

Godoi Filho, J. D de. 1986. Aspectos geológicos do Pantanal Matogrossense e de sua área de influência. In: Anais do $1^{\circ}$ Simpósio sobre recursos naturais e sócioeconômicos. Brasília - DF. DDT - Embrapa/CPAP - UFMS: 1986, 63-76p.

Gohain, K., Parkash, B. 1990. Morphology of the Kosi megafan. In: Rachocki, A. H \& Church, M. (Org). Alluvial fans: a Field approach. Chichester: Wiley, cap. 3, p. 151$178 p$.

Golterman, H. L., Clymo, R. S., Ohnstad, M. A., Blakwell Sci. 1978. Methods for Physical and Chemical Analysis of Fresh Waters. IBP Handbook $n^{\circ} 8,176-177 p$.

Gomes, C. B. 1984. Técnicas analíticas instrumentais aplicadas à Geologia. São Paulo, Edgard Blücher: PROMINÉRIO.

Gottgens, J. F., Perry, J. E., Fortney, R. H., Meyer, J. E., Benedict, M., Rood, B. E. 2001. The Paraguay-Paraná Hidrovía: Protecting the Pantanal with Lessons from the Past. BioScience, Vol. 51, $\mathrm{n}^{\circ}$ 4, 301-308p.

Gregory, K. L. 1976. River Channel Changes. Publication of the Brittish Geomorphological research group. 448 p.

Hamilton, S. K. 1999. Potential effects of a major navigation project (Paraguay-Parana hidrovia on inundation in the Pantanal floodplains. Regulated Rivers: Research \& Management $15: 289-299 p$.

Harvey, A. M., Mather, A. E., Stokes, M. 2005. Alluvial Fans: Geomorphology, Sedimentology, dynamics..

Hauck, C., Isaksen, K., Mühll, D. V., Sollid, J. L. 2004. Geophysical surveys designed to delineate the altitudinal limit of Mountain Permafrost: an example from Jotunheimen, Norway. Wiley InterScience, Process 15: 191-205p.

Irion, G., Junk, W. J., Mello, A. S. N. 1997. The large central Amazonian river floodplains near Manaus: geological, climatological, hydrological, and geomorphological aspects, 23-46p. In: Junk, W. J. (ed), The central Amazonian floodplain: ecology of a pulsing system. Ecological Studies 126, Springer, Berlin.

Izaguirre, I., Vinocur, A. 1994. Typology of shallow lakes of the Salado River Basin (Argentina), based on phytoplankton communities. Hydrobiologia, v. 277, Issue 1, 49$62 \mathrm{p}$.

Yang, X., Williams, M. A. J. 2003. The ion chemistry of lakes and late Holocene desiccation in the Badain Jaran Desert, Inner Mongólia, China. Elsevier, Catena, v. 51, Issue 1, 45-60p. 
Kardjilov, M. I., Gíslason, S. R., Gísladóttir, G. 2006. The effect of gross primary production, net primary production and net ecosystem exchange on the carbon fixation by chemical weathering of basalt in northeastern Iceland. Journal of Geochemical Exploration, v. 88, Issues 1-3, 292-295p.

Klammer, G. 1982. Die Palaeowuste des Pantanal von Mato Grosso und die Pleistozane Klimageschichte des brasilianischen Randtropen. Zeitschrift für Geomorphologie 26 : 393-416p.

Kleerekoper, H. 1944. Introdução ao estudo da Limnologia. Ministério da Agricultura, Departamento Nacional da Produção Animal, Divisão de Caça e Pesca. Rio de Janeiro, 329p.

Kolada, A., Soszka, H., Cydzik D., Golub, M. 2005. Abiotic typology of Polish lakes, Limnologica, 35, p. 50-150.

Jha, P. K., Tiwari, J., Singh, U. K., Kumar, M., Subramanian, V. 2009. Chemical weathering and associated $\mathrm{CO} 2$ consumption in the Godavari river basin, India. Chemical Geology, V. 264, Issues 1-4, 364-374p.

Junk, W. J. 1997. The central Amazon floodplain: ecology of a pulsing system. Springer -Verlag Berlim Heidelberg, 520p.

Junk, W. J., Silva, C. J. da. 1995. Neotropical Floodplains: A comparison between the Pantanal of Mato Grosso and the large Amazonian River Floodplains, p. 195-217. In: J. G. Tundisi; C. E. M. Bicudo \& T. Matsumura-Tundisi. (Eds). Limnology in Brazil. Rio de Janeiro, Brazilian Academy of Sciences, Brazilian Limnological Society, 376p.

Latrubesse, E. M e Stevaux, J. C. 2006. Características físico-bióticas e problemas ambientais associados à planície aluvial do Rio Araguaia, Brasil Central. Revista UnG - Geociências, v. 5, N. 1, 65-76p.

Ledru, M. P., 1993. Late Quaternary environmental and climatic changes in Central Brazil, Quat Res 39: 90-98p.

Lerman A., Imboden D. M. e Gat J. R. 1995. Physics and Chemistry of Lakes. Springer-Verlag, Berlin and Heidelberg GmbH and Co. KG. 350p.

Lerman, A., Wu, L., Mackenzie, F. T. 2007. CO2 and H2SO4 consumption in weathering and material transport to the ocean, and their role in the global carbon balance. Elsevier, Marine Chemistry, v. 106, Issues 1-2, 326-350p.

Lesch, S. M., Corwin, D. L. 2005. Apparent soil electrical conductivity mapping as an agricultural management tool in arid zone soils. Elsevier 46: 351-378p.

Mariot, M., Dubal, Y., Furian, S., Sakamoto, A., Vallès, V., Fort, M., Barbiero, L. 2007. Dissolved organic matter fluorescence as a water-flow tracer in the tropical wetland of Pantanal of Nhecolândia, Brazil. Elsevier, 184-193p.

Martinelli, L. A., Ometto, J. P. H. B., Ferraz, E. S., Victoria, R. L., Camargo, P. B. C., Moreira, Z. 2009. Desvendando questões ambientais em isótopos estáveis. São Paulo, Oficina de Textos, 130p.

Mascré, C. 2004. Le flúor dans lês eaux de la Nhecolândia - Pantanal do Mato Grosso do Sul - Brèsil : etude régionale et locale. Rapport de estage ingenieur maitre. Université de Provance Aix - Marseille I. France.

McCarthy, T. S., Metcalfe, J. 1990. Chemical sedimentation in the Okavango Delta, Botswana. J chem Geol 89: 157-178p. 
McCarthy, T. V. S., Mciver, J. R., Verhagem, B. T. 1991. Groundwater evolution, chemical sedimentation and carbonate brine formation on an island in the Okavango Delta swamp, Botswana. Applied Geochemistry, 6, 577-596p.

McGlue M. M., Silva, A., Corradini, F. A., Zani, H., Trees, M. A., Ellis, G. S., Parolin M., Swarzenski, P. W., Cohen, A. S., Assine, M. L. 2011 Limnogeology in Brazil's "forgotten wilderness": a synthesis from the large floodplain lakes of the Pantanal. $J$ Paleolimnol 46: 273-289p.

McNeill, J. D. 1980. Electromagnetic terrain conductivity measurement at low induction numbers. Tech. Note TN-6, Geonics Limited, Ontário, Canadá.

McNeill, J. D., Bosnar, M., 1999. Application of dipole-dipole electromagnetic systems for geological depth sounding. Technical Note TN-31. Geonics Limited, Mississauga, ON, Canadá.

Melack, J. M. 1988. Saline Lakes: proceeding of the Third International Symposium on Inland Saline Lakes, held at Nairobi, Kenya, August 1985. Reprinted from Hydrobiologia, vol. 158.

Melack, J. M. 1984. Amazon Floodplain lakes: shape, fetch and stratification. Verh. Internacional Verein limnology, Stuttgart, V. 22, 1278-1282p.

Melack, J. M. 1988. Primary producer dynamics associated with evaporative concentration in a shallow, equatorial soda lake (Lake Elmenteita, Kenya). Hydrobiologia 158: 1-14.

Melack, J. M., Forsberg, B., 2001. Biogeochemistry of Amazon floodplain lakes and associated wetlands, p. 235-276. In: McClain, M. E., Victoria, R. L., Richey, J. E. (Eds.), The biogeochemistry of the Amazon basin and its role in a changing world. New York: Oxford University Press. 384 p.

Mello, C. L., Metelo, C. M. S., Suguio, K., Kohler, H. C. 1999. Quaternary sedimentation, neotectionics and the evolution of the Doce River Middle Valley Lake system (southeastern Brazil). Revista do Instituto Geológico, IG São Paulo, 20 (1/2), 29-36p.

Meybeck, M. 1995. Global Distribution of Lakes. 2 ed. Spring - Verlag Berlin Heidelberg, 334p.

Michel, P. 1973. Les bassins des fleuves Sénegal et Gambie. Etude Géomorphologique, Mémoire ORSTOM, 63. ORSTOM, Paris.

Mohamedou, A., Ould, A. A., Barbiero, L., Caruba, R., Valles, V. 1999. Geochemistry of clay dunes and associated pan in the Senegal Delta, Mauritania. Arid Soil Research and Rehabilitation 13, 265-280 p.

Mougenot, B. 1982. Etude pedologique de la cuvette de N'Tiagar (Partie Nord), delta du fleuve Sénégal, Reserach Report. Dakar-Hann ORSTOM Centre, Dakar, Senegal.

Mousinho de Meis, M. R. 1977. As unidades morfo-estratigráficas neoquaternárias do médio Rio Doce. Anais da Academia Brasileira. V. 49, n. 3, 443-459p.

Mousinho de Meis, M. R., Monteiro, A. M. F. 1979. Upper Quaternary "rampas". Rio Doce valley, Southeastern Brazilian Plateau. Zeitschr. Für Geomorph., 23, 132-151p. 
Mousinho de Meis, R. M.; Moura, J. R. S. 1984. Upper Quaternary sedimentation and hillslope evolution: Southeastern Brazilian Plateau. Amer. J. Sci. 284 (3): 241254p.

Mousinho de Meis, M. R. e Tundisi, J. G. 1986. Geomorphology and limnological processes as a basis for lake typology: the middle Rio Doce Valley Lake System. Anais da Academia Brasileira de Ciências. vol. 58 , 103 - 120p.

Mourão, G. M.; Ishii, I. H., Campos, Z. M. S. 1988. Alguns fatores limnológicos relacionados com a ictiofauna de baías e salinas do Pantanal da Nhecolândia, MS, Brasil. Acta Limnológica Brasileira, Vol. II, 181-198p.

Mörner, N. -A., Etiope, G. 2002. Carbon degassing from the lithosphere. Global Planet, Change, v 33, Issues 1-2, 185-203p.

Nils-Axel, M., Etiope, G. 2002. Carbon degassing from the lithosphere. Global and Planetary Change, v. 33, Issues 1-2, 185-203p.

Nímer, E. 1989. Clima. In: IBGE. Geografia do Brasil - Região Centro-Oeste. Rio de Janeiro, IBGE, V.1, 23-34p.

Panosso, R. F., Attayde, J. L. e Muehe, D. 1998. Morfometria das lagoas Imboassica, Cabiúnas, Comprida e Carapebus: implicações para seu funcionamento e manejo. In: F. A. Esteves (Ed), Ecologia das lagoas costeiras na restinga de Jurubatiba e do município de Macaé. NUPEM/UFRJ/CNPq, Rio de Janeiro, 442p.

Parizzi, M. G., Labouriau, M. L., Kohler, H. C. 1998. Genesis and environmental history of Lagoa Santa, southeastern Brazil. The Holocene V. 8, No 3, 311-321p.

Penteado, M. Fundamentos de Geomorfologia. $2^{\circ}$ ed., Rio de Janeiro: IBGE, 1978. $154 p$.

Pflug, R. 1969. Quaternary lakes of Eastern Brazil. Photogrammetria 24:29-35.

Pokrovsky, O. S., Schott, J., Dupré, B. 2006. Basalt weathering and trace elements migration in the boreal Arctic zone. Journal of Geochemical Exploration, v. 88, Issues 1-3, 304-307p.

Por, F. D. 1995. The Pantanal of Mato Grosso (Brazil): World's Lasgest Wetlands. Monographiae Biologicae 73. Kluwer Academic Publisher, Dordrecht/ Boston/London. Printed in the Netherlands: 123p.

Por, F. D., Imperatriz-Fonseca, V. L., Lencione Neto, F. 1997. O Pantanal do Mato Grosso. Universidade de São Paulo. São Paulo. 33p.

Pott, A. e Pott, V. J. 2004. A flora do Pantanal. In: Revista Ação Ambiental, Universidade Federal de Viçosa, Ano VI, $n^{\circ} 26$, Janeiro/Fevereiro 2004, Viçosa MG, 19-23p.

RadamBrasil, Ministério das Minas e Energias. Secretaria Geral. 1982a. Folha SE. 21 Corumbá e parte da Folha SE. 20, Geologia, Geomorfologia, Pedologia, Vegetação e Uso potencial da terra. Vol. 27, Rio de Janeiro.

Ramberg, L., Wolski, P. 2008. Growing islands and sinking solutes: processes maintaining the endorheic Okavango Delta as a freshwater system, Plant Ecology, 196, 215-231.

Rezende Filho, A. T. 2006. Estudo da variabilidade e espacialização das unidades da paisagem: Banhado (baía/vazante), Lagoa Salina e Lagoa Salitrada no Pantanal 
da Nhecolândia, MS. Dissertação de Mestrado (Universidade Federal do Mato Grosso do Sul), Aquidauana, MS, 122p.

Rezende Filho, A. T. 2011. Variabilidade química das águas na Bacia do Alto Paraguai: uma compartimentação do Pantanal Mato-grossense. Tese de Doutorado (Faculdade de Filosofia, Letras e Ciências Humanas - Universidade de São Paulo) São Paulo, 142p.

Rezende Filho, A. T. ; Furian, S. ; Victoria, R. L. ; Mascré, C. ; Valles, V. ; Barbiero, L. 2012. Hydrochemical variability at the Upper Paraguay Basin and Pantanal wetland. Hydrology and Earth System Sciences Discussions (Print), v. 9, p. 31293163. No Prelo

Riccomini, C., Giannini, P. C. F., Mancini, F. 2003. Rios e Processos Aluviais. In: Teixeira, W., Toledo, M. C. M. de., Fairchild, T. R., Taioli, F. (Orgs) Decifrando a Terra. São Paulo: Oficina de Textos.

Richards, L. A. 1954. Diagnosis and improvement of saline and alkali soils. US Agricultural Handbook n. 60, USDA Washington VIII, 160p.

Roelandt, C., Godderis, Y., Bonnet, M. -P., Seyler, F. 2006. Modelling transfer of elements from the continent to the ocean at the large watershed scale in a tropical environment. Geochimica et Cosmochimica Acta, V. 70, Issue 18, Supplement, Page A537.

Salvi-Sakamoto, L. L. 2001. A chuva na Bacia do alto Paraguai: contribuição ao estudo de aspectos das flutuações inter-anuais durante o século $X X$. Tese de Doutorado (Faculdade de Filosofia, Letras e Ciências Humanas - Universidade de São Paulo), São Paulo.

Santos, K, R. de S., Jacinavicius, F. R., Sant'Ana, C. L. 2011. Effects of the pH on growth and morphology of Anabaenopsis elenkinii MILLER (Cyanobacteria) isolated from the alkaline shallow lake of the Brazilian Pantanal. Fottea (11) p.119-126p.

Santos, K. R. de S. 2008. Biodiversidade de algas e cianobactérias de três lagoas ("salina", "salitrada" e "baía") do Pantanal da Nhecolândia, MS, Brasil. Dissertação de Mestrado (Instituto de Botânica da Secretaria do Meio ambiente do Estado de São Paulo), São Paulo, 229p.

Schiffer, D. M. 1998. Hydrology of Central Florida Lakes - A primer. (U. S. Geological Survey circular: 1137), 38p.

Sheets, K. R., Hendrickx, J. M. H. 1995. Noninvasive Soil Water Content Measurement Using Electromagnetic Induction. Water Resources Research. Vol. 31(10), 2401-2409pp.

Shiraiwa, S. 1994. Flexura da litosfera continental sob os Andes Centrais e a origem da Bacia do Pantanal. Tese de Doutorado (Instituto Astronômico e Geofísico, Universidade de São Paulo) São Paulo, 86p.

Sieppel, S. J., Hamilton, S. K., Melack, J. M. 1992. Inundation area and morphometry of lakes on the Amazon River floodplain. Archives of Hydrobiology, v. 123, p. 385400.

Silva, J. S. V., Abdon, M. M. 1998. Delimitação do Pantanal brasileiro e suas subregiões. Pesquisa Agropecuária Brasileira, Brasília, v.33, Número Especial, p.17031711. 
Silveira, O. F. M. 1998. A Planície Costeira do Amapá: dinâmica de ambiente costeiro influenciado por grandes fontes fluviais quaternárias. Tese (Doutorado Universidade Federal do Pará) Belém, 215p.

Sinha R., Bapalu G. V., Singh L. K., et al., 2008. Flood Risk Analysis in the Kosi River Basin, North Bihar using Multi-Parametric Approach of Analytical Hierarchy Process (AHP). Photonirvachak - Journal of the Indian Society of remote Sensing 36 (4), 335-349.

Sinha, R.; Friend, P. F. 1999. Pedogenic alteration in the overbank sediments, north Bihar plains, India. Journal of the Geological Society of India, 53, 163-171.

Soares, A. P., Soares, P. C., Assine, M. L. 2003. Areias e Lagoas do Pantanal, Brasil: herança paleoclimática? Revista Brasileira de Geociências, vol. 33 (2): 211 $224 p$.

Soffiati, A. N. 1998. Aspectos históricos das lagoas do Norte do Estado do Rio de Janeiro. In: Esteves, F. A. Ecologia das lagoas costeiras do Parque Nacional da Restinga de Jurubatiba e do Município de Macaé (RJ). Rio de Janeiro, RJ: NUPEM, p. 1-38.

Soltner, D. 1979. Les bases de la production végetale. Tome 1 « le sol », $8^{\mathrm{e}}$ édition, Collection Sciences et Téchniques Agricoles, França, 452p.

Sperling, E. 1999. Morfologia de lagos e represas. Belo Horizonte, Segrac.

Sudduth, K. A., Drummond, S. T., Kitchen, N. R. 2001. Accuracy issues in electromagnetic induction sensing of soil electrical conductivity for precision agriculture. Elsevier 31: 239-264p.

Tarifa, J. R. 1986. O sistema climático do Pantanal: da compreensão do sistema à definição de prioridades de pesquisa climática. In: Anais do $1^{\circ}$ Simpósio sobre Recursos Naturais e Sócio-Econômicos do Pantanal, 27 de novembro a 4 de dezembro de 1984, Corumbá (MS): 9-27 p.

Timms, B. V. 2005. Salt lakes in Australia: present problems and prognosis for the future. Spring 552: 1-15p.

Tricart, J. 1954. Influence dês sols salés sur la deflation éolienne em basse Mauritania et dans le delta du Sénégal. Revue de Geomorphologie Dynamique, 5, 124-132.

Tricart, J. 1982. Paisagem e Ecologia. Inter-Facies - Escritos e documentos. UNESP, São José do Rio Preto, n. 76, 43p.

Tricart, J. 1988. El Pantanal: un ejemplo del impacto geomorfologico sobre el ambiente. Informaciones geograficas (Chile), 29: 81-97p.

Tudorancea, C.; Harrison, A. D. 1988. The benthic communities of the saline lakes Abijata and Shala (Ethiopia). Hydrobiologia 158: 117-123. Melack, J. M. (Ed (Saline Lakes).

Tundisi, J. G;. Matsumura-Tundidi, T. 1982. Estudos Limnológicos no sistema de lagos do Médio Rio Doce, MG-Brasil. Anais do II Sem. Regional de Ecologia, 133258.

Tundisi, J. G., Matsumura-Tundisi, T., Rocha, O. 1999. Theoretical basis for reservoir management. In Theoretical reservoir ecology and its applications. (J. G. Tundisi e 
M. Straskraba, eds). International Institute of Ecology, São Carlos and Backhuys Publishers, AH Leiden, p. 505-528.

Tundisi, J. G. et al. 2008. Conservação e uso sustentável de recursos hídricos. In: Barbosa, F. A. (Org.) Ângulos da água: desafios da integração. Belo Horizonte: Editora UFMG, p.57-83.

Tundisi, J. G., Tundisi, T. 2008. Limnologia. São Paulo, Oficina de textos, 631p.

Uagoda, R., Coelho Neto, A. L., Avelar, A. de S. 2009. Morfologia de depressões fechadas em domínio cárstico-quartzítico na Bacia do Ribeirão Santana/MG: Datações absolutas iniciais. Revista Brasileira de Geomorfologia, v. 10, n 2, p. 9198.

Uagoda, R. 2006. Reconhecimento de relevo cárstico em rochas quartzíticas: bacia hidrográfica do Ribeirão Santana, médio Vale do Rio Paraíba do Sul/Dissertação de Mestrado, PPGG-UFRJ, Rio de Janeiro.

Ussami, N., Shiraiwa, S., Domingues, J. M. L. 1999. Basement reactivation in a subAndean foreland flexural bulge: The Pantanal Wetland, SW Brasil. Tectonics, (18) p.25-39.

Wetzel, R. G. \& Likens, G. E. 1991. Limnological Analyses (2 ${ }^{\text {nd }}$ Ed.). Springer-Verlag. New York: 69-80p.

Wilhelmy, M. (1958). Das Grosse Pantanal. Die Weltumschau, 18: p.55-559.

Wood, R. B.; Talling, J. F. 1988. Chemical and algal relationships in a salinity series of Ethiopian inland waters. Hydrobiologia 158: 29-67. Melack, J. M. (ed) Saline Lakes

Vallès, V., De Cockeborne, A. M. 1992. Elaboration d'um logiciel de géochimie appliqué à l'étude de La qualité des eaux. Coloque "altération et restauration de la qualité des eaux continentales", Port Leucate, 1 et 2 Oct. 27-30p.

Valles, V., Pachepsky, I., Ponizovsky, A. A. 1991. Ivariant criteria for irrigation water quality assessment in arid and semi-arid regions. In: Genesis and Control of Fertility of Salt Affected Soils: ISSS Subcommission on Salt Affected Soils Science, USSR, V.V. Dokuchaev Soil Institute Moscow, p. 330-333.

Vieira, S. R. Geoestatística em estudos de variabilidade espacial. Campinas: IAC, 1998.

Zani, H., Assine, M. L., Araújo, B. C., Merino, E. R., Silva, A., Facincani, E. M. 2006. Lobos deposicionais na evolução do megaleque do Rio Taquari, Pantanal MatoGrossense. In: INPE, $1^{\circ}$ Simpósio de Geotecnologias no Pantanal, Campo Grande, Brasil, p. 285-292.

Zani, H. 2008. Mudanças morfológicas na evolução do megaleque do Taquari: uma análise com base em dados orbitais. Dissertação (Mestrado em Geociências e Meio Ambiente) - Universidade Estadual Paulista, Rio Claro, 96 p.

Zani, H., Assine, M. A. 2009. Análises de superfícies de tendência com dados SRTM: estudo de caso na bacia sedimentar do Pantanal. Anais XIV simpósio Brasileiro de Sensoriamento Remoto, Natal, Brasil, INPE, p. 3403-3410. 


\begin{abstract}
ANEXO 1
Descrições morfológicas da trincheira e sequências de solos estudadas.
\end{abstract}


A seguir apresentaremos as descrições morfológicas da trincheira (Salina Verde) e das tradagens realizadas nas Salinas Verde, Grande, Preta e 60 mil.

\section{TRINCHEIRA SALINA VERDE:}

A trincheira (Figura) aberta em setembro/09 na Salina Verde, período seco, está localizada entre as Coordenadas Geográficas 19²8'20.80"S e 5603'28.10 W, próximo ao T4 descrito na sequência de solo.
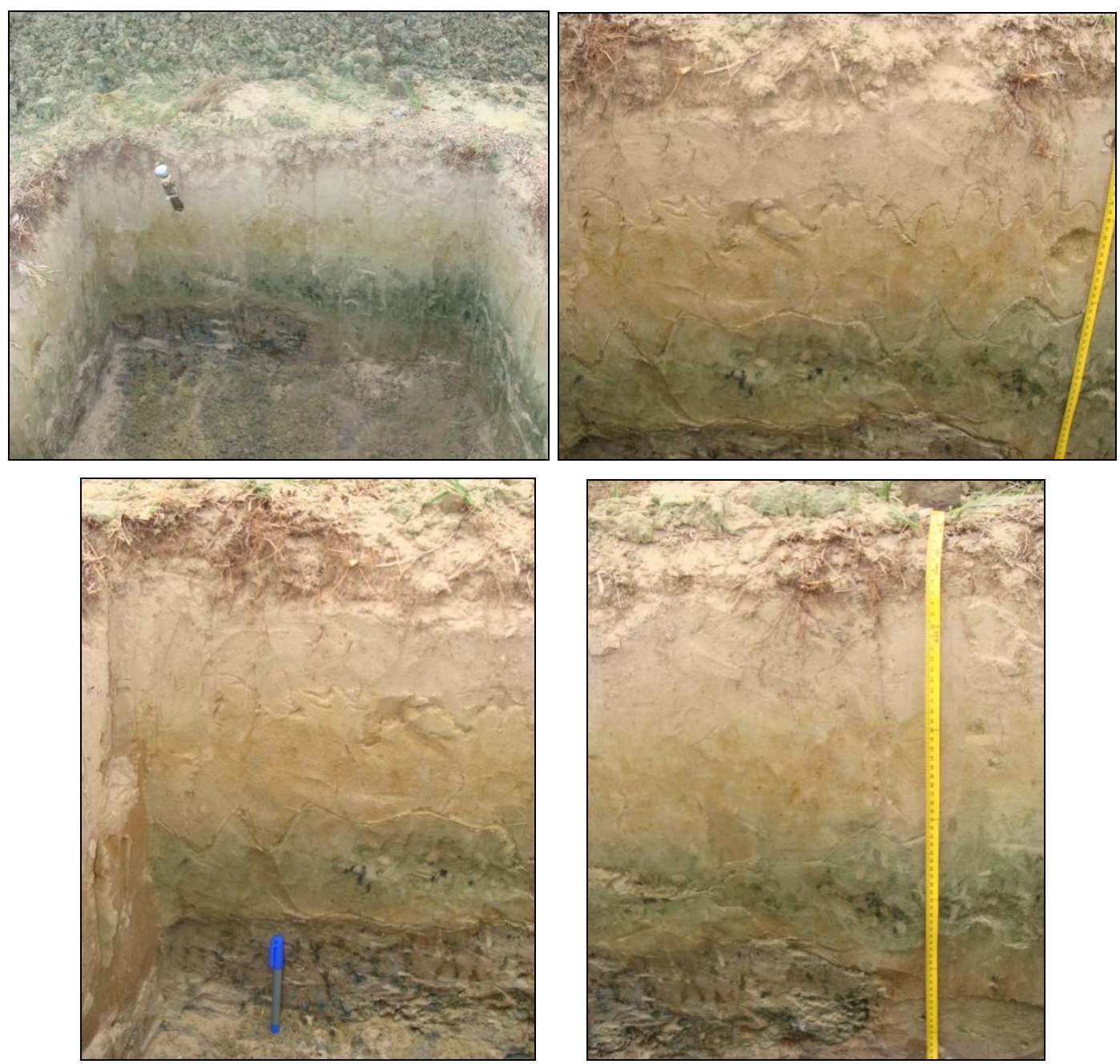

Da descrição da trincheira decorrem as seguintes informações sobre os horizontes:

Variando de 0-8 cm = Bem ondulado, horizonte com areia solta (fina) onde se concentram as raízes. Às vezes associados às raízes com pequenos agregados. 
Esses agregados podem chegar até $0,5 \mathrm{~cm}$, pouco coesos. Cores: 2.5 Y 7/2 (seco); 2.5 Y $5 / 4$ (úmido)

8 - $18 \mathrm{~cm}=$ Bem no centro desse horizonte arenoso e com poucas raízes, areia de fina para media (friável), se debita com agregado, sub-angular e friável, pouco coeso. Estrutura pouco desenvolvida, tem porosidade tubular muito fina associada a raízes. Porosidade de empacotamento (intersticial). Cor: 2.5 Y 7/4 (seca); 2.5 Y 4/3 (úmida). Limite com a camada superior é todo festonado.

Obs: Podem ter localmente manchas verdes amareladas, ligeiramente marrons, sobretudo, em volta das raízes. Essas manchas estão um pouco mais consistentes que a matriz. Cor: 5Y 6/4 (seco); 5Y 4/4 (úmida)

18 - $30 \mathbf{~ c m ~ = ~ O ~ l i m i t e ~ c o m ~ a ~ c a m a d a ~ i n f e r i o r ~ e ́ ~ f e s t o n a m e n t o ~ m a i s ~ l a r g o . ~ N a ~ m a t r i z ~}$ aparecem manchas de areia lavada arredondada, que podem ter de $1 \mathrm{~cm}$ a $0,5 \mathrm{~cm}$ de diâmetro, algumas com formas mais alongadas de até $2 \mathrm{~cm}$. Manchas associadas a raízes ocres escuras. Variação entre as cores: 5y 3/2 (no entorno das raízes); 5y 4/3 e 4 (pequenos volumes ligeiramente mais coesos).

30 - $50 \mathrm{~cm}=$ Contêm muito mais areia lavada de forma arredondada, maiores. Quebra em agregados ondulares. Cor (volumes com verde mais nítido) Gley 35G; O mais claro entre Gley 1 5/10Gy e 5/5Gy; Úmido entre Gley 1 4/5Gy e 4/10Gy. Os volumes verdes mais nítidos são ligeiramente mais coesos, com um pouco de argila com certa pegajosidade. Cor dos núcleos mais coesos; Gley $12.5 / 5 G$

$46-50 \mathrm{~cm}=$ Limite inferior ondulado com interpenetração a esquerda do corte ocorre nessa "laje" sobre a qual tem uma areia areno-argilosa de cor cinza. Essa areia tem uma espessura de 2 a $3 \mathrm{~cm}$ onde já tem volumes verdes mais endurecidos bem nítidos ainda argilosos. Parece uma auréola cinza no entorno da laje.

Obs: A argila cinza pode estar no entorno dos volumes da laje, cor entre; 5y R 5/1 e 5yR 5/2. Os volumes têm forma de poupée.

$50-70 \mathrm{~cm}=\mathrm{Na}$ base da trincheira. Lado direito do perfil onde não tem a laje abaixo do horizonte esverdeado, um horizonte de cor mais cinza com manchas menos contrastadas, ligeiramente mais escurecidas. Cor $5 y$ y $5 / 3$ (úmida, naturalmente); $5 y$ 4/3 (molhada, fica mais uniforme) 
50 - $60 \mathrm{~cm}=$ Trata-se da parte endurecida que se localiza do centro do perfil para a esquerda. Nela se observam volumes bem endurecidos. A parte exterior é bem dura, mas se consegue quebrar. A textura é pouco argilosa, e cor Gley 1 2.5/5G. No interior dos volumes aparecem algumas manchas ocres.

Nesses núcleos porosidades tubulares finas bem desenvolvidas, inferiores a 0,1 a 0,2 milímetros. Manchas ocres 7.5YR 4/6 e 4/4. Entre os volumes mais endurecidos na laje encontra-se quase água livre.

Base da trincheira = Toda festonada, cinza mais escuro muito poroso, manchas de areia lavada, onde os poros são bem nítido, porosidade tubular. Cor: 5y 5/11 e 2.5y $6 / 4$.

SALINA VERDE - Descrições das tradagens para elaboração da sequência de solo:

\section{T1 (Borda da Cordilheira)}

0 - 50 = areia bege sem horizonte orgânico.

50 = areia verde clara.

60 = algumas manchas orgânicas, pouco úmido e cinza.

$70=$ matriz mais acinzentada manchas ocres difusas, mancha cinza mais escura.

$80=$ marrom claro.

90 = pouco mais argiloso na ponta do trado cinza bem úmido.

$100=$ matriz cinza argiloso com areia marrom com colunas de argila cinza.

105 = horizonte cinza dominante argiloso muito úmido.

110 = cinza mais claro mais argiloso com alguns nódulos centimétricos de calcário.

120 = matriz cinza com partes verdes endurecidas.

\section{T2 (5,65 m abaixo da t1)}

$0-15=$ arenoso bege seco.

20 = ponta do trado começa esverdear.

30 = a cor verde começa a ficar mais escura.

$40=$ verde mais escura mais ainda arenoso

50 = camada argilosa cinza, some orgânico transição entremeados o verde mais manchas ocre.

60 = camada argilosa cinza com parte endurecida verde e ocre.

$70=$ idem

\section{T3 (5,65 $\mathrm{m}$ abaixo da t3)}

$0-20=$ areia bege sem horizonte orgânico.

20 = começa esverdear, pouco argiloso.

$30=$ arenoso esverdeado mais intenso. 
$40=$ arenoso esverdeado mais escuro.

$50=$ idem

60 = passa do esverdeado para um pouco mais cinza mais úmido.

70 = ligeiramente mais argiloso, cor mais cinza, ainda esverdeado saturado de água.

80 = bastante nódulos centimétricos, ainda arenoso, matriz cinza esverdeado arenosa.

90 = na ponta do trado fica mais cinza, pouco argiloso.

100 = cinza marrom, desaparecimento dos nódulos.

$110=$ idem, com aparecimento de água livre.

120 = pouco mais argiloso, na ponta do trado matriz cinza mais argilosa, muito úmido com volumes verdes.

$130=$ material cinza, matriz cinza com volume verde bastante contrastado.

\section{T4 (10 $\mathrm{m}$ abaixo da $\mathrm{t} 3$ )}

$0-20=$ areia fina, verde (mais amarelo).

$20-40=$ arenoso esverdeado e na ponta do trado pequeno volume argiloso verde endurecido com auréola de ferrugem.

$40-45$ = um material mais claro, areia cinza claro com alguns nódulos centimétricos.

$60=$ volumes difusos de argilas verdes.

70 = fica marrom claro, com nódulos maiores, ainda bem arenoso, na ponta do trado marrom acinzentado mais escuro ainda arenoso.

80 = marrom mais escuro, orgânico ainda arenoso com nódulos pluricentimetricos .

90 = material mais cinza argiloso, muito úmido, já com volumes esverdeados ligeiramente endurecidos.

100 = camada verde nítida, matriz cinza argilosa com volumes verdes marrons endurecidos.

$110=$ idem

\section{T5 (10 $\mathrm{m}$ abaixo da $\mathrm{t} 4)$}

$0-20=$ areia verde clara.

$20-30$ = na ponta do trado verde mais escuro.

40 = na ponta do trado alguns nódulos endurecidos da camada verde $(5 \mathrm{~cm})$.

45 = areia lavada cinza claro com nódulos centimétricos.

$60-90=$ areia lavada.

$90=$ lençol freático.

\section{T6 (10m abaixo do T5)}

$0-20=$ areia verde com manchas pretas (orgânicas) um pouco mais argilosas.

$20-30=$ areia verde com volumes argilosos da camada verde.

40 = na ponta do trado volumes da camada verde pouco endurecido dentro da matriz areia verde.

50 = camada verde saturada de água .

60 = areia lavada cinza com nódulos. 
$70=$ areia lavada cinza clara.

80 = lençol freático.

\section{T7 - 10m do T6 (final da grama)}

0 - 20 = orgânico pouco argiloso, a $5 \mathrm{~cm}$ chega na areia.

$20-40=$ verde argiloso.

$40-50=$ camada verde pouco endurecido.

\section{T8 - entre T1 e T2 a 3m do T1}

$0-30=$ areia bege clara.

40 = ligeiramente esverdeando na matriz bege.

50 = ponta do trado argiloso mosqueado de cinza, ocre e a areia verde claro muito pouco marcado.

60 = cinza argiloso com nódulos verdes mais secos e com manchas ocres.

70 = camada verde endurecida com nódulos centimétricos.

80-120 = camada cinza com manhas esverdeadas endurecidas com manchas ocres mais secas.

130 = camada verde endurecida .

SALINA GRANDE E PRETA - (atravessando a cordilheira):

\section{S1 - Início da cordilheira (Salina Grande)}

$0-20 \mathrm{~cm}$ = textura arenosa, matriz mais clara cor 10YR 6/3, com pequenos volumes milimétricos de MO (Matéria Orgânica) escuros.

30 = textura arenosa, muito úmida e com muitas raízes, mantendo-se com volumes escuros. Na ponta do trado a cor fica mais clara.

$40=$ idem, cor $10 \mathrm{YR} 7 / 3$.

A partir de 40 , a cor fica mais homogênea, arenosa, diminui o número de raízes. Cor 10YR entre $7 / 2$ e 3.

60 = idem, aparecem raízes e algumas manchas mais escuras (das próprias raízes).

$80=$ idem, com raiz e no entorno volumes mais escuros.

95 = na ponta do trado presença de raízes e aparecem pequenos nódulos de $\mathrm{MO}$ associado à raiz, arenoso e mesma cor do anterior.

115 = na ponta do trado material cinza mais escuro, ligeiramente argiloso. Cor $5 \mathrm{Y}$ $5 / 3$ (cor predominante), tem pequenas manchas mais amareladas $2.5 \mathrm{Y} 4 / 4$, tem raízes, com pequenos volumes (cinza). Não dá para ver a cor dos pequenos volumes, mais vai para o tom gley $5 / 10 y$.

$120=$ Laje

Obs. Não é possível continuar a tradagem.

\section{S2 - Limite do início da grama}

$0-30=$ textura arenosa, pequenos nódulos escuros de MO. Cor 10yr 6/3.

40 = cor idem, porém mais homogênea, textura arenosa, mais úmido e sem MO. 
60 = idem, mais úmido. Ponta do trado aparece estria de MO.

70 = na ponta do trado: textura areno-argilosa, cor cinza gley 5/10y, dentro do material argiloso há poucos nódulos.

75 - 85 = tem uma passagem abrupta do arenoso para a camada verde, dentro do verde tem bastante água (bem úmido). Gley 2.5/10y (nessa mistura cinza). Gley 4/10y (verde).

90 = laje

Obs: Material muito endurecido, não dá para seguir com a tradagem.

\section{S3 - Meio da grama}

0 - 20 = arenoso, cor $10 y r$ 6/3, com raízes e $\mathrm{MO}$ (idem ao anterior).

40 = idem, muito úmido, arenoso.

60 = idem, água livre, diminui a quantidade de raízes.

70 = na ponta do trado, estrias de MO cinza, água livre.

Até $90=$ material cinza entre gley $5 / 10 \mathrm{~g}$ e $5 / 5 \mathrm{bg}$, ligeiramente argiloso.

90 = Laje, não dá para seguir com as tradagens.

\section{S4 - Limite inferior da grama (fim)}

0 - 30 = idem anterior, menos raízes e nódulos de MO.

40 = água livre.

\section{S5 - Topo da cordilheira}

0 - 20 = textura arenosa, pouco mais fina $10 \mathrm{yr} 5 / 3$, com manchas mais claras.

$40=$ pequenos volumes de areia lavada.

50 = bem úmido e com raízes.

60 = na ponta do trado totalmente seco, friável. Até os $55 \mathrm{~cm}$ chegou a frente de umequitação.

$80=$ idem

$100-110=$ idem

110 = começa ficar mais úmido e a aparecer linhas difusas de MO.

140 = idem, ligeiramente mais úmido.

150 = idem, com algumas raízes e pequenos volumes (estriados de $\mathrm{MO}$ ).

$180=$ idem

$195-200=$ ponta do trado material mais escuro, mais argiloso cinza.

\section{S6 - Limite da grama (início) salina preta}

$0-20=$ muita raiz com volumes de $\mathrm{MO}$, arenoso.

20 - 30 = idem, um pouquinho mais claro na ponta do trado.

30 - 50 = mais claro, arenoso, úmido, diminuem as raízes, aparecem estrias de MO.

60 = mais úmido, mesma cor da tradagem anterior (10yr 5/3) e volumes de MO.

80 = água livre.

90 = idem, nível do lençol. 


\section{S7 - Início da cordilheira Salina Preta}

$0-20=$ arenoso, cor (10yr 5/3), idem anterior.

$50=$ arenoso, um pouco mais claro $(10 \mathrm{yr} 6 / 4)$, pequenas manchas amareladas muito difusas.

70 = arenoso, e mais úmido.

$70-120=$ idem, água livre

SALINA 60 MIL - Descrições das tradagens:

\section{S1 - Topo da cordilheira}

0 - $60 \mathrm{~cm}$ = úmido, arenoso, bege mais escuro.

$60=$ bege claro

70 = nódulos de calcário (isolados)

110 = idem, nódulos de calcário no meio da areia.

$120=$ somem os nódulos

170 = muito úmido, com manchas mais marcadas.

180 = areia amarelada, água livre.

220 = camada verde.

S2

$0-50 \mathrm{~cm}$ = areia bege mais úmida e mais escura (sem manchas).

$50=$ bege mais claro.

100 = água livre no bege claro.

170 = filetes de cinza com manchas ocres na matriz arenosa bege e, também manchas escuras (passagem abrupta).

190 = camada verde com manchas ocres no meio.

S3

$0-120 \mathrm{~cm}=$ arenoso, bege claro.

120 = água livre.

$145=$ idem

160 = cinza esverdeado - camada verde .

S4

$0-100 \mathrm{~cm}=$ arenoso, areia bege clara, cimentada.

$105=\mathrm{M} . \mathrm{O}$

$135=$ idem

150 = início cinza argiloso na ponta do trado.

152 = camada verde bem nítida, bem marcada.

S5

$0-40 \mathrm{~cm}=$ areia bege.

$40-90=$ areia verde (algas).

$90-120=$ areia bege.

$120-140=$ areia com MO.

140 = cinza arenoso úmido.

180 = mesma matriz, água livre.

$230=$ camada verde . 
S6

$0-25 \mathrm{~cm}=$ arenoso argiloso com algas, esverdeado e pouco cimentado.

$25-70$ = início areia lavada.

80 = cinza arenoso, sem M.O bem marcada, água livre.

$140=$ idem.

SALINA VERDE À BAÍA (atravessando a cordilheira).

T1 - Salina Verde (Topo da cordilheira)

0 - 61 = úmido, arenoso, bege escuro.

$160=$ material mais seco e mais claro.

$240=$ material mais úmido.

$370=$ nódulos de ferro ligeiramente endurecidos, material argiloso.

390 = cinza argiloso (esverdeado) com nódulos centimétricos.

T2 -

$0-50=$ arenoso, areia pouco mais escura, úmida

$50-100=$ areia seca

$100-175=$ areia mais clara

$175=$ material endurecido (laje)

T3 -

$0-55=$ arenoso, bege escuro.

$55=1 \mathrm{dem}$

$270=$ Idem, mais claro

290 = mais seco, cinza claro .

$295=$ laje

T4 -

0 - 40 = arenoso, bege claro.

$40=$ fica mais seco

$175=$ mais claro

235 - laje

T5 -

$0-50=$ arenoso

$50-70=$ arenoso argiloso, mais seco cimentado (laje). 


\begin{abstract}
ANEXO 2
Resultados das análises granulométricas do solo realizadas no Laboratório de Sedimentologia Instituto de Geociências/USP e Departamento de Ciência do solo ESALQ/USP.
\end{abstract}


Frações granulométricas em (\%) das amostras de solo das Salinas Preta, Grande, Verde e Topo da Cordilheira (entre Salina Grande e Preta).

\begin{tabular}{|c|c|c|c|c|c|c|c|c|c|c|c|}
\hline \multicolumn{12}{|c|}{ FRAÇÕES GRANULOMÉTRICAS EM (\%) } \\
\hline \multirow[t]{2}{*}{ Nome dos Horizontes } & \multicolumn{6}{|c|}{ Areia } & \multicolumn{3}{|c|}{ Películos } & \multirow{2}{*}{$\begin{array}{c}\text { Textura de } \\
\text { solo }\end{array}$} & \multirow{2}{*}{$\begin{array}{l}\text { Profundidade } \\
\text { (cm) }\end{array}$} \\
\hline & Muito Grossa & Grossa & Média & Fina & Muito Fina & Total & Silte & Argila & Total & & \\
\hline \multirow{3}{*}{ S.V (1) } & 0,01 & 0,31 & 8,62 & 70,15 & 19,40 & 98,49 & 1,35 & 0,14 & 1,51 & \multirow{3}{*}{$\begin{array}{l}\text { Areia } \\
\text { Areia } \\
\text { Areia }\end{array}$} & \multirow{3}{*}{$\begin{array}{c}\text { 0-8 (Tr1) } \\
\text { 8-18 (Tr2) } \\
18-30(\operatorname{Tr} 3)\end{array}$} \\
\hline & 0,01 & 0,43 & 11,48 & 54,75 & 32,34 & 99,00 & 0,75 & 0,25 & 0,99 & & \\
\hline & 0,00 & 0,29 & 8,75 & 44,42 & 44,19 & 97,66 & 1,42 & 0,89 & 2,34 & & \\
\hline \multirow{3}{*}{ Arenoso bege Claro S.G } & 0,00 & 0,39 & 11,01 & 40,63 & 42,94 & 94,97 & 4,24 & 0,76 & 5,03 & \multirow{3}{*}{$\begin{array}{l}\text { Areia } \\
\text { Areia } \\
\text { Areia }\end{array}$} & \multirow{3}{*}{$\begin{array}{c}40-60 \text { (T1) } \\
0-40 \text { (T3) } \\
70-90 \text { (T3) }\end{array}$} \\
\hline & 0,00 & 0,36 & 10,52 & 48,62 & 39,38 & 98,88 & 0,88 & 0,24 & 1,12 & & \\
\hline & 0,00 & 0,47 & 11,82 & 49,97 & 30,72 & 92,97 & 5,78 & 1,14 & 7,03 & & \\
\hline \multirow{2}{*}{ Arenoso Bege Claro T.C } & 0,00 & 0,31 & 11,92 & 41,21 & 41,11 & 94,55 & 0,86 & 0,93 & 5,45 & \multirow{2}{*}{$\begin{array}{l}\text { Areia } \\
\text { Areia }\end{array}$} & \multirow{2}{*}{$\begin{array}{c}0-40(\mathrm{~T} 5) \\
80-100(\mathrm{~T} 5)\end{array}$} \\
\hline & 0,01 & 0,53 & 12,27 & 47,81 & 36,39 & 97,01 & 2,72 & 0,24 & 2,99 & & \\
\hline \multirow{2}{*}{ Arenoso Bege Claro S.P } & 0,01 & 0,57 & 11,44 & 46,39 & 36,36 & 94,77 & 4,95 & 0,25 & 5,23 & \multirow{2}{*}{$\begin{array}{l}\text { Areia } \\
\text { Areia }\end{array}$} & \multirow{2}{*}{$\begin{array}{c}50-70(\mathrm{~T} 6) \\
0-20(\mathrm{~T} 7)\end{array}$} \\
\hline & 0,01 & 0,40 & 14,48 & 43,52 & 35,10 & 93,52 & 4,12 & 1,55 & 6,48 & & \\
\hline \multirow{3}{*}{ S.V (3) } & 0,01 & 0,29 & 7,13 & 42,98 & 43,34 & 93,74 & 4,29 & 1,94 & 6,26 & \multirow{3}{*}{$\begin{array}{l}\text { Areia } \\
\text { Areia } \\
\text { Areia }\end{array}$} & \multirow{3}{*}{$\begin{array}{c}30-50(\operatorname{Tr} 4) \\
50-70(\operatorname{Tr} 6) \\
60(\operatorname{Tr}) \\
\end{array}$} \\
\hline & 0,07 & 0,24 & 8,09 & 42,00 & 39,67 & 90,07 & 7,07 & 2,86 & 9,93 & & \\
\hline & 0,06 & 0,26 & 11,31 & 38,56 & 42,85 & 93,04 & 4,87 & 2,09 & 6,96 & & \\
\hline \multirow{3}{*}{ Franco arenoso S.G } & 0,43 & 0,81 & 8,21 & 40,63 & 31,15 & 81,23 & 10,94 & 7,35 & 18,31 & \multirow{4}{*}{$\begin{array}{l}\text { Areia franca } \\
\text { Areia franca } \\
\text { Areia franca } \\
\text { Areia franca }\end{array}$} & \multirow{4}{*}{$\begin{array}{c}46-50 \\
120(\mathrm{~T} 1) \\
75-85(\mathrm{~T} 2) \\
200(\mathrm{~T} 5)\end{array}$} \\
\hline & 0,36 & 2,30 & 10,01 & 47,66 & 26,46 & 86,79 & 10,67 & 2,54 & 13,21 & & \\
\hline & 0,46 & 1,08 & 8,99 & 36,49 & 32,49 & 79,51 & 11,61 & 8,61 & 20,22 & & \\
\hline Franco arenoso T.C & 0,27 & 0,73 & 10,05 & 49,43 & 17,02 & 77,51 & 10,63 & 11,74 & 22,49 & & \\
\hline S.V (3) & 1,12 & 3,03 & 8,45 & 37,74 & 27,56 & 77,91 & 10,91 & 10,89 & 21,81 & Franco arenosa & $50-60(\operatorname{Tr} 5)$ \\
\hline
\end{tabular}

S.V = Salina Verde, S.G = Salina Grande, S. P = Salina Preta, $T . C=$ Topo da Cordilheira, $T r=$ Trincheira, $T 1=$ Pontos de Tradagens. 
Resultados das frações granulométricas (\%) referente à Trincheira e Sequência do solo da Salina Verde realizado no Departamento de Ciência do solo (Esalq).

\begin{tabular}{|c|c|c|c|c|c|c|c|c|c|c|c|}
\hline \multicolumn{12}{|c|}{ FRAÇÕES GRANULOMÉTRICAS EM (\%) } \\
\hline \multirow[t]{2}{*}{ No dos Horiz. } & \multicolumn{6}{|c|}{ Areia } & \multicolumn{3}{|c|}{ Películos } & \multirow{2}{*}{$\begin{array}{c}\text { Textura de } \\
\text { solo }\end{array}$} & \multirow{2}{*}{$\begin{array}{l}\text { Profundidade } \\
\text { (cm) }\end{array}$} \\
\hline & Muito Grossa & Grossa & Média & Fina & Muito Fina & Total & Silte & Argila & Total & & \\
\hline \multirow{4}{*}{ (1) } & 0,1 & 0,4 & 11,7 & 69,8 & 16,7 & 98,5 & 0,2 & 1,3 & 1,5 & \multirow{4}{*}{$\begin{array}{l}\text { Areia } \\
\text { Areia } \\
\text { Areia } \\
\text { Areia }\end{array}$} & \multirow{4}{*}{$\begin{array}{c}0-8(\mathrm{Tr}) \\
8-18(\mathrm{Tr}) \\
18-30(\mathrm{Tr}) \\
0-20(\mathrm{~T} 4)\end{array}$} \\
\hline & 0,1 & 0,5 & 12,0 & 68,6 & 17,4 & 98,5 & 0,2 & 1,3 & 1,5 & & \\
\hline & 0 & 0,3 & 9,0 & 69,0 & 19,3 & 97,6 & 1,2 & 1,3 & 2,5 & & \\
\hline & 0 & 0,3 & 11,1 & 69,4 & 16,6 & 97,4 & 0,1 & 2,5 & 2,6 & & \\
\hline (2) & 0,1 & 0,5 & 6,0 & 61,1 & 24,9 & 92,5 & 2,5 & 5,0 & 7,5 & Areia & $20-60(T 4)$ \\
\hline (6) & 0,1 & 0,4 & 8,4 & 62,5 & 22,7 & 94,0 & 1,0 & 5,0 & 6,0 & Areia & $30-60$ (T3) \\
\hline \multirow{7}{*}{ (3) } & 0,1 & 0,3 & 7,5 & 61,3 & 22,8 & 92,0 & 3,0 & 5,0 & 8,0 & \multirow{7}{*}{$\begin{array}{c}\text { Areia } \\
\text { Franco argilo } \\
\text { arenosa } \\
\text { Franco argilo } \\
\text { arenosa } \\
\text { Areia } \\
\text { Areia } \\
\text { Franco argilo } \\
\text { arenosa } \\
\text { Areia } \\
\end{array}$} & \multirow{3}{*}{$\begin{array}{l}30-50(\mathrm{Tr}) \\
46-50(\mathrm{Tr}) \\
50-60(\mathrm{Tr})\end{array}$} \\
\hline & 0,3 & 0,8 & 7,1 & 50,7 & 22,6 & 81,5 & 3,4 & 15,0 & 18,4 & & \\
\hline & 1,7 & 2,6 & 7,6 & 42,8 & 18,6 & 73,3 & 1,6 & 25,1 & 26,7 & & \\
\hline & 0 & 0,4 & 8,0 & 60,2 & 24,1 & 92,6 & 2,4 & 5,0 & 7,4 & & 50/70 (Tr) \\
\hline & 0,1 & 0,3 & 8,0 & 60,6 & 23,2 & 92,1 & 2,9 & 5,0 & 7,9 & & 60DUR (Tr) \\
\hline & 0,1 & 0,6 & 3,0 & 36,0 & 27,3 & 67,0 & 5,3 & 27,7 & 33 & & $1,20-1,50$ (T3) \\
\hline & 0,4 & 0,7 & 6,2 & 59,8 & 21,6 & 88,6 & 3,9 & 7,5 & 11,4 & & $80(\mathrm{~T} 4)$ \\
\hline (5) & 0,5 & 0,4 & 12,6 & 63,4 & 16,1 & 92,9 & 2,1 & 5,0 & 7,1 & Areia & $0-10(\mathrm{~T} 7)$ \\
\hline \multirow{3}{*}{ (7) } & 0,2 & 0,5 & 1,6 & 30,2 & 30,8 & 63,2 & 4,2 & 32,6 & 36,8 & \multirow{3}{*}{$\begin{array}{c}\text { Argilo arenosa } \\
\text { Areia }\end{array}$} & $1,10-1,20(\mathrm{~T} 4)$ \\
\hline & 0,3 & 1,6 & 4,6 & 28,9 & 20,2 & 55,5 & 6,2 & 38,3 & 44,5 & & \multirow{2}{*}{$\begin{array}{c}1,60-1,80(\mathrm{~T} 3) \\
40-50(\mathrm{~T} 7)\end{array}$} \\
\hline & 0,3 & 0,8 & 10,4 & 57,9 & 18,0 & 87,3 & 5,2 & 7,5 & 12,7 & & \\
\hline (4) & 1,4 & 3,0 & 5,7 & 38,7 & 19,2 & 68,0 & 6,9 & 25,1 & 32 & $\begin{array}{c}\text { Franco argilo } \\
\text { arenosa }\end{array}$ & $1,80(\mathrm{~T} 8)$ \\
\hline
\end{tabular}


Os gráficos a seguir ilustram os resultados das análises granulométricas (em \%) das Salinas Verde, Grande e Preta.
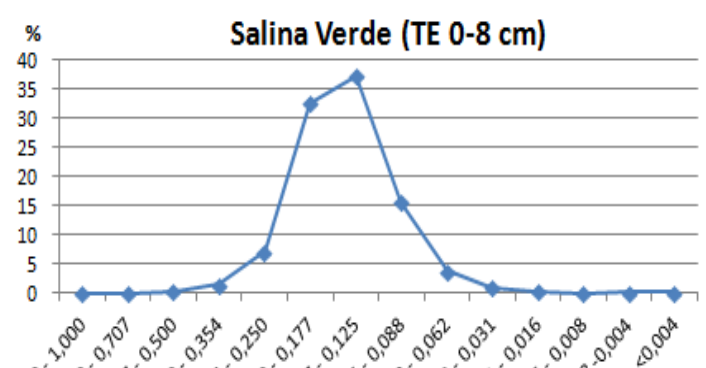

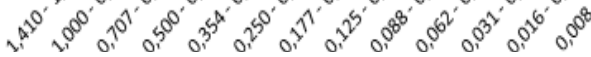

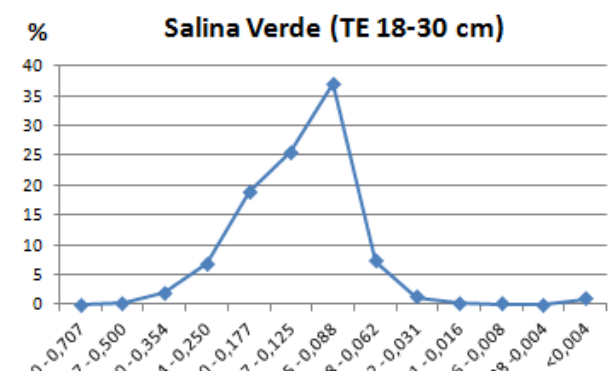

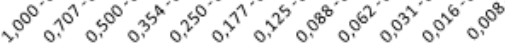

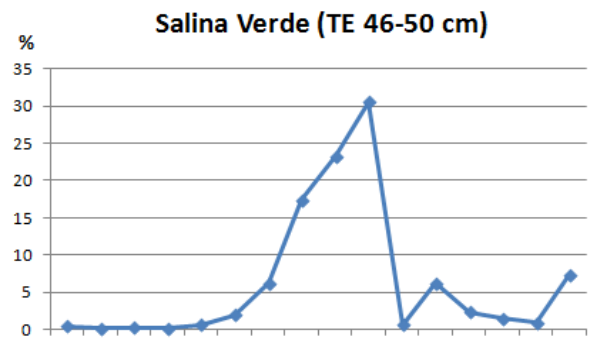

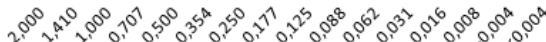

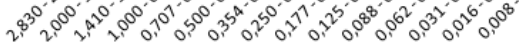
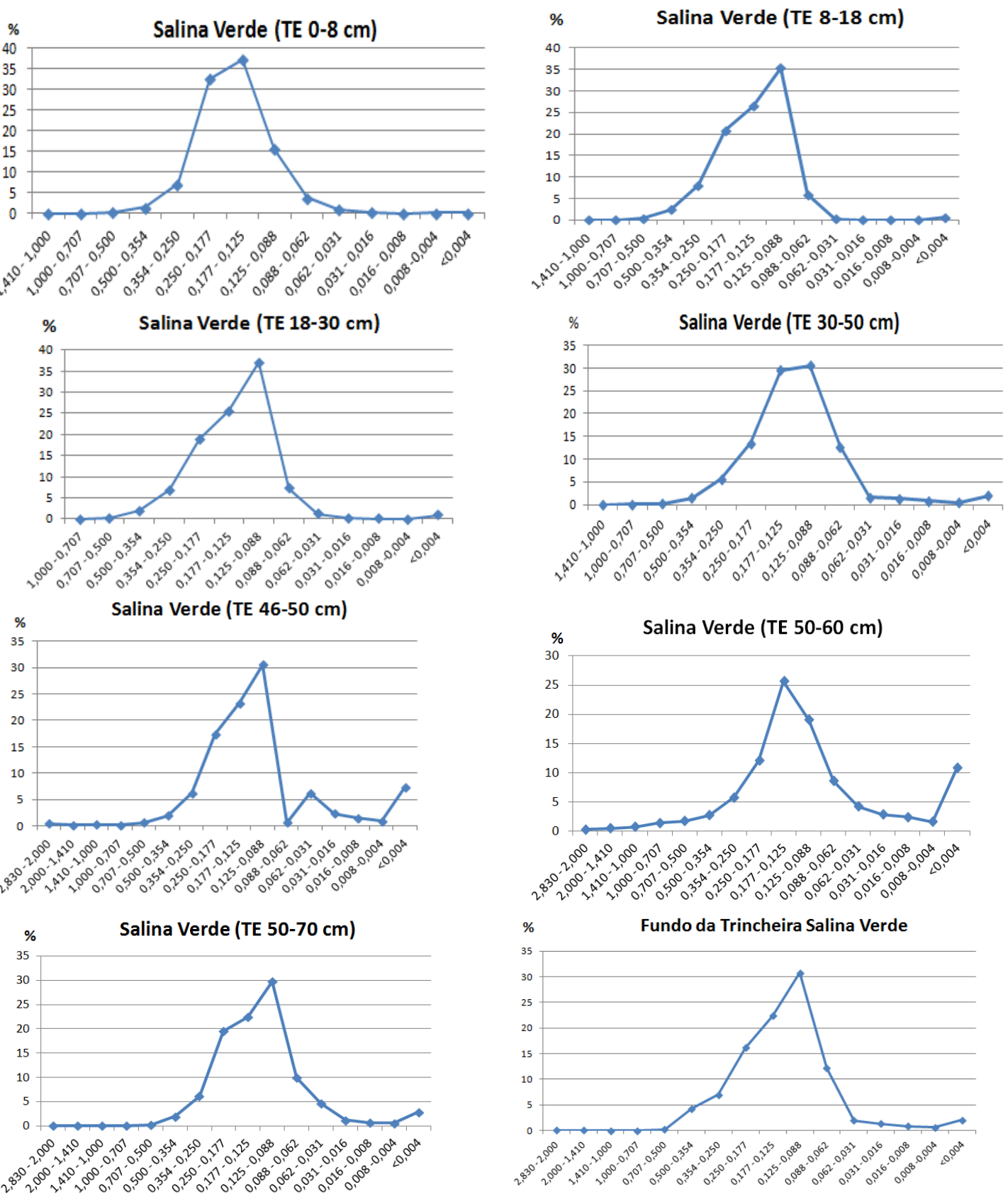

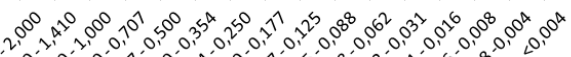

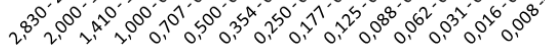
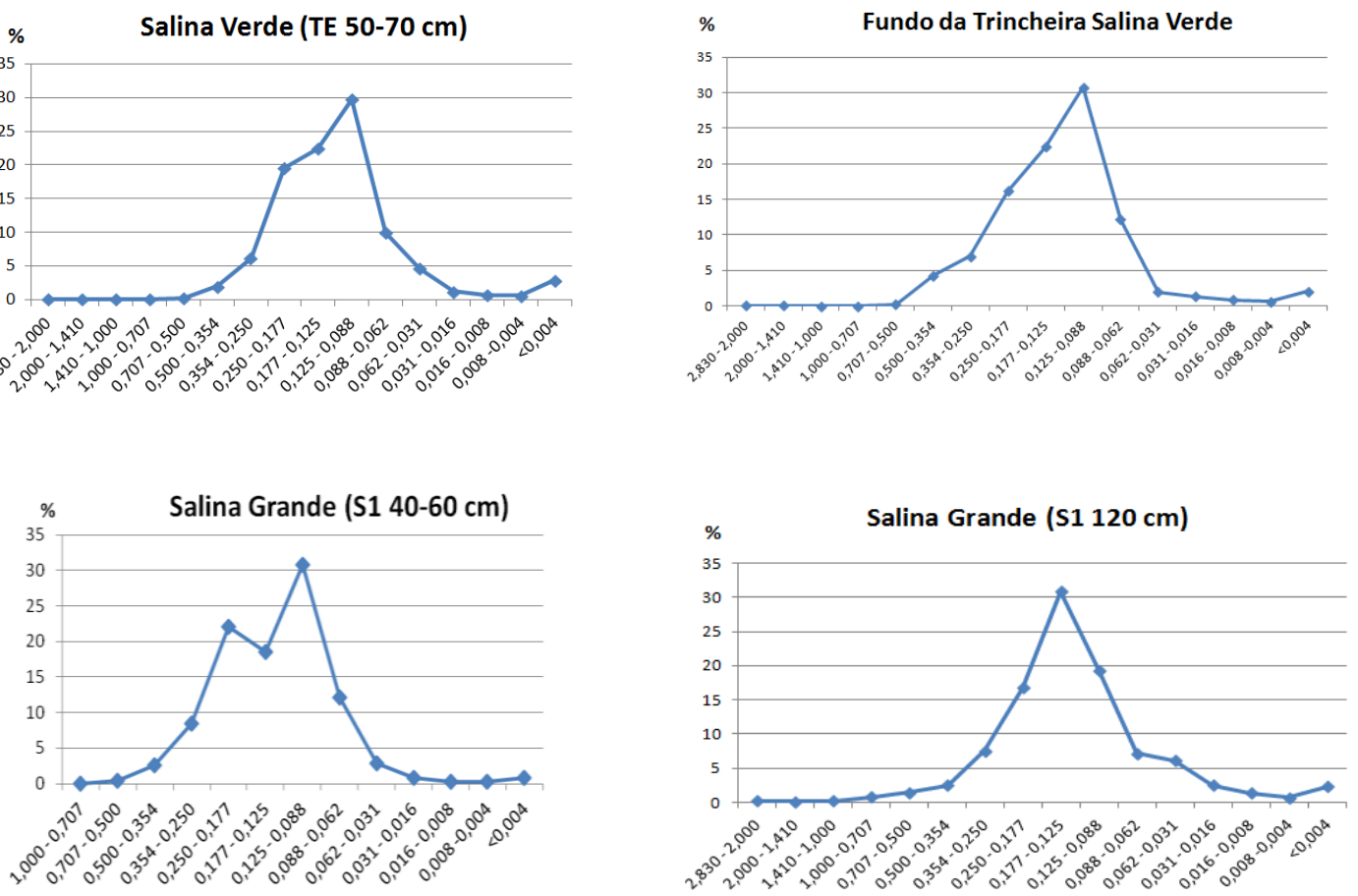

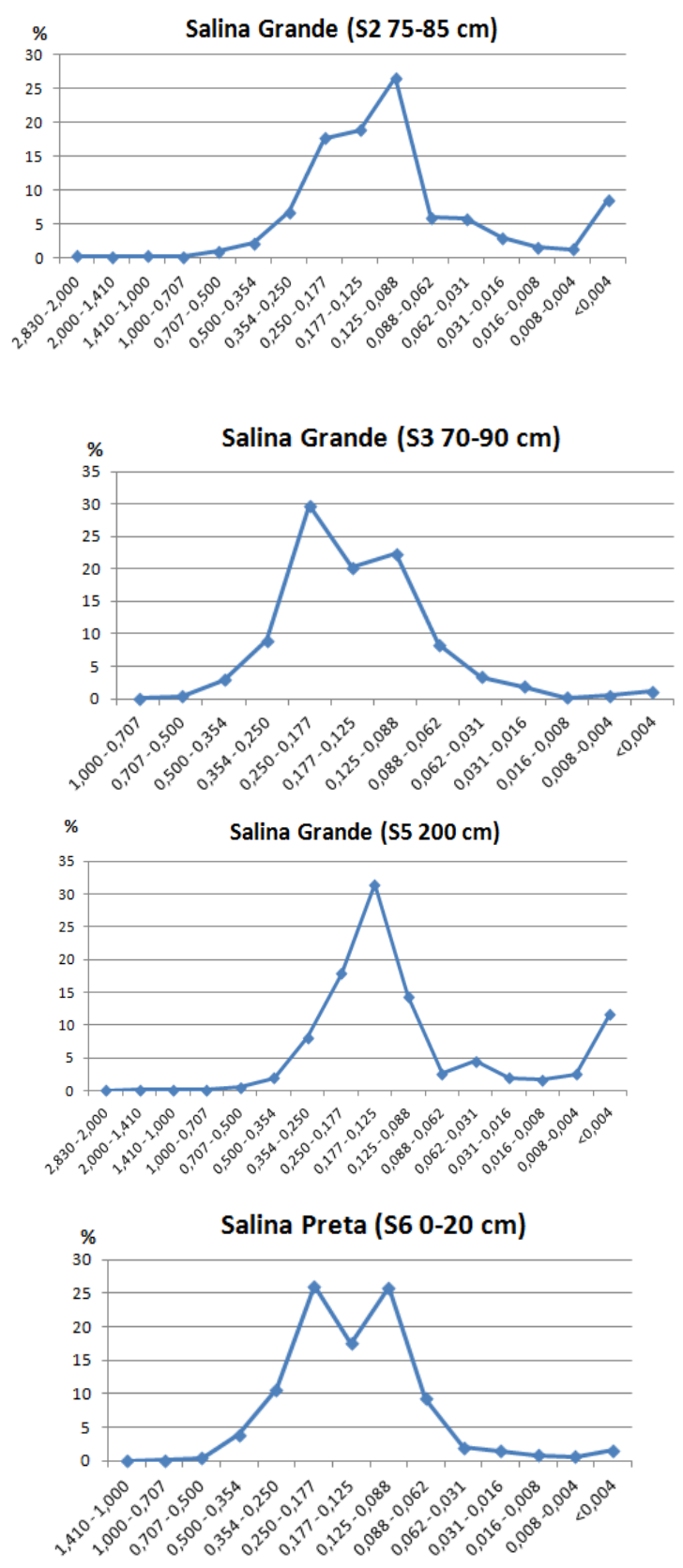
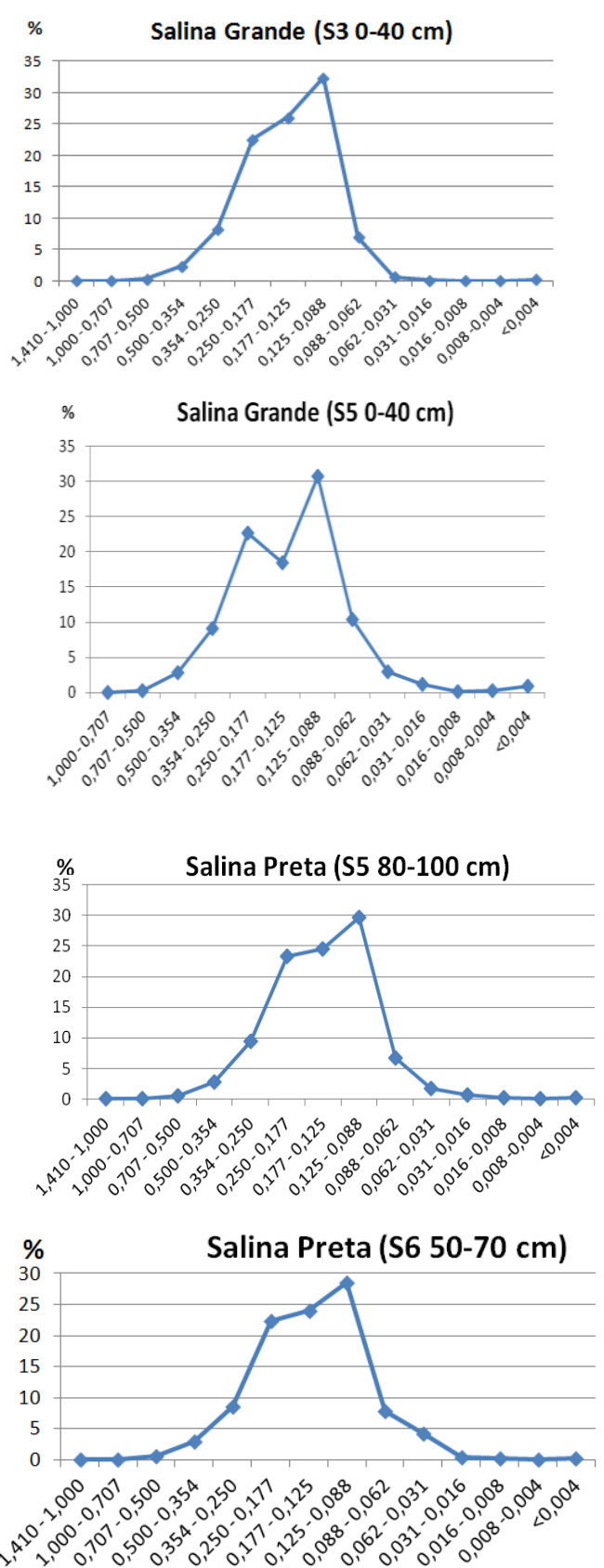


\begin{abstract}
ANEXO 3
Resultados das análises das lâminas de argila realizadas no Laboratório de Difração de Raios X no Instituto de Geociências/USP.
\end{abstract}




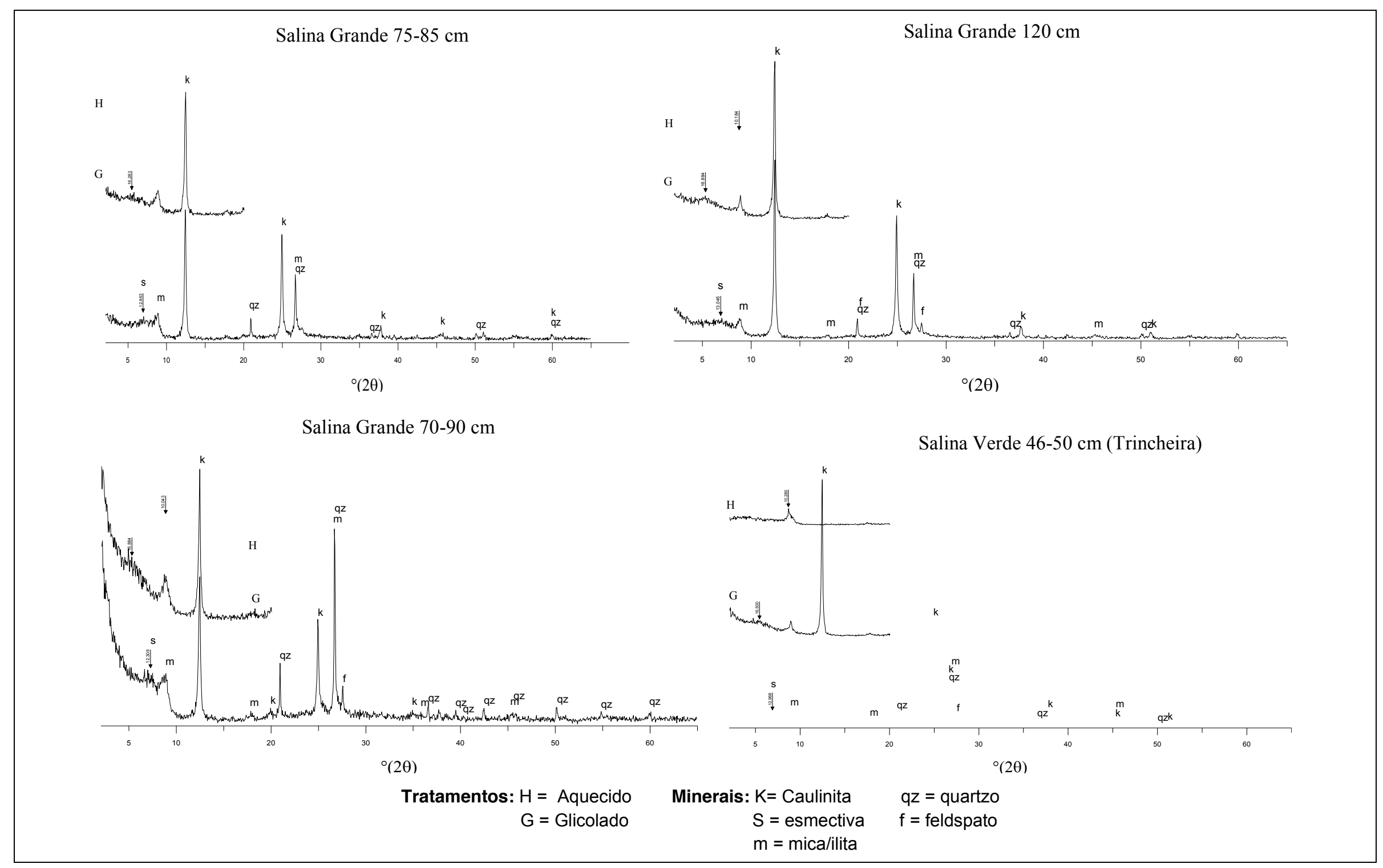




\section{ANEXO 4}

Resultados das análises realizadas no Departamento de solo ESALQ/USP. 


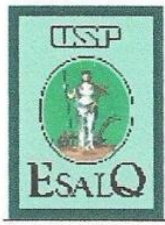

Universidade de São Paulo

Escola Superior de Agricultura "Luiz de Queiroz"

Departamento de Ciência do Solo

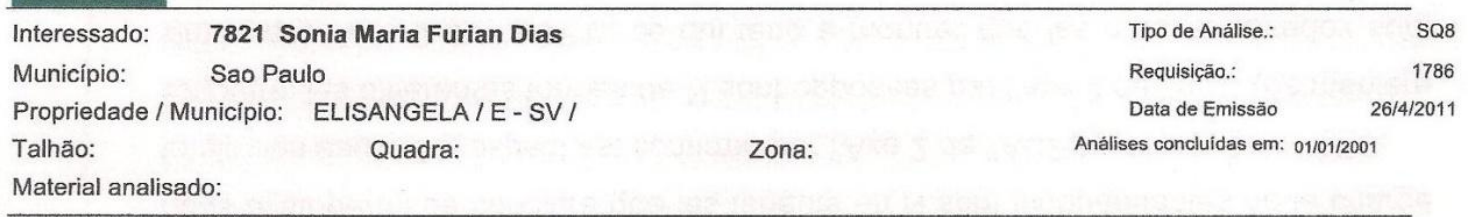

Resultado-de-Análise

\begin{tabular}{|c|c|c|c|c|c|c|c|c|c|c|c|c|c|c|}
\hline Amostra & $\mathrm{pH} \mathrm{H} 2 \mathrm{O}$ & $\mathrm{pH} \mathrm{KCl}$ & M. O. & $P$ & $\mathrm{Na}$ & K & $\mathrm{Ca}$ & $\mathrm{Mg}$ & Al & $\mathrm{H}+\mathrm{Al}$ & SB & СТC & V & $\mathrm{m}$ \\
\hline TR1/0-8 & 8,0 & 7,0 & 1 & 8 & 0,3 & 2,0 & 10 & 2 & 0 & 4 & 14,6 & 18,6 & 78,57 & 0 \\
\hline TR1/08-18 & 8,4 & 5,9 & 3 & 3 & 1,2 & 4,2 & 1 & 1 & 0 & 3 & 6,8 & 9,7 & 70,27 & 0 \\
\hline TR1/18-30 & 8,7 & 6,3 & 1 & 3 & 3,8 & 6,2 & 1 & 1 & 0 & 5 & 11,5 & 16,6 & 69,4 & 0 \\
\hline TR1/30-50 & 9,5 & 6,7 & 1 & 4 & 6,7 & 5,2 & 1 & 1 & 0 & 2 & 13,3 & 15,5 & 85,96 & 0 \\
\hline TR1/46-50 & 8,9 & 6,5 & 2 & 4 & 14,0 & 13,7 & 8 & 3 & 0 & 3 & 38,1 & 41,0 & 92,95 & 0 \\
\hline TR1/50-60 & 8,6 & 6,4 & 1 & 5 & 30,8 & 32,0 & 13 & 4 & 0 & 8 & 79,6 & 87,2 & 91,29 & 0 \\
\hline TR1/50-70 & 9,7 & 7,1 & 1 & 2 & 5,0 & 3,4 & 1 & 1 & 0 & 2 & 10,4 & 12,6 & 82,72 & 0 \\
\hline TR1/F.TRINCH. & 9,6 & 7,1 & 1 & 2 & 5,9 & 4,6 & 1 & 1 & 0 & 2 & 12,5 & 14,3 & 87,37 & 0 \\
\hline$T 3 / 30-60$ & 9,3 & 7,1 & 1 & 3 & 3,6 & 4,0 & 1 & 1 & 0 & 4 & 9,6 & 13,2 & 72,55 & 0 \\
\hline T3/1,20-1,50 & 6,0 & 3,4 & 4 & 2 & 7,2 & 9,4 & 16 & 13 & 10 & 27 & 45,7 & 73,2 & 62,45 & 19 \\
\hline T3/1,60-1,80 & 6,5 & 3,9 & 4 & 12 & 1,2 & 4,1 & 34 & 32 & 1 & 16 & 71,0 & 86,9 & 81,68 & 2 \\
\hline $\mathrm{T} 4 / 0,80$ & 5,8 & 4,1 & 1 & 23 & 1,2 & 4,0 & 37 & 32 & 1 & 15 & 73,7 & 88,6 & 83,26 & 1 \\
\hline $\mathrm{T} 4 / 0-20$ & 10,0 & 8,3 & 1 & 6 & 9,5 & 8,9 & 5 & 1 & 0 & 4 & 24,8 & 28,4 & 87,24 & 0 \\
\hline $\mathrm{T} 4 / 20-60$ & 9,9 & 8,7 & 0 & 1 & 12,1 & 5,8 & 3 & 1 & 0 & 4 & 21,6 & 25,2 & 85,63 & 0 \\
\hline$T 4 / 1,10-1,20$ & 7,0 & 4,8 & 1 & 3 & 30,5 & 20,0 & 25 & 14 & 1 & 6 & 90,2 & 96,4 & 93,62 & 1 \\
\hline T7/0-10 & 9,5 & 8,4 & 13 & 78 & 20,3 & 12,4 & 24 & 14 & 0 & 4 & 71,3 & 74,9 & 95,17 & 0 \\
\hline$T 7 / 40-50$ & 9,8 & 8,1 & 8 & 94 & 19,5 & 19,0 & 94 & 5 & 0 & 4 & 137,5 & 141,1 & 97,43 & 0 \\
\hline $\mathrm{T} 8 / 1,80$ & 6,2 & 3,2 & 1 & 1 & 2,8 & 7,5 & 105 & 7 & 4 & 28 & 122,9 & 151,1 & 81,33 & 3 \\
\hline
\end{tabular}

\footnotetext{
Unidades:

M.O. (g.Kg-1); P (mg.Kg-1); Na, K, Ca, Mg, Al, H+Al, SB, T (mmolc Kg-1), V e m (\%).

Métodos:

$\mathrm{pH}$ em água; $\mathrm{pH}$ em KCl

M.O. - dicromato/titulométrico;

P-Mehlich 1; K, Ca, Mg, Na - extração pelo Acetato de Amônio;

$\mathrm{Al}$ - extração pelo $\mathrm{KCl} 1 \mathrm{~mol} . \mathrm{L}-1$;

$\mathrm{H}+\mathrm{Al}$ - extraçăo $\mathrm{Ca}(\mathrm{CH} 3 \mathrm{OO}) 2 . \mathrm{H} 2 \mathrm{O}$;

Observaçöes:

Amostra col:

(\#) elemento näo det

Luis Antonio Silva Júnio

- Químico Responsável -
}

Pag. 01 de 02

Av. Pádua Dias, 11 - Caixa Postal 09 - CEP 13418-900 - Piracicaba, SP - Brasil fone (19) 3417-2117/3417-2145 - Fax (19) 3417-2110

e-mail: Isn@esalq.usp.br - Home-page: http:// www.solos.esalq.usp.br 